JOSÉ RICARDO BUENO GALVÃO

AVALIAÇÃO DA RELAÇÃO PRESSÃO x CONSUMO, EM ÁREAS CONTROLADAS POR VÁLVULAS REDUTORAS DE PRESSÃO (VRPS)

ESTUDO DE CASO: REDE DE DISTRIBUIÇÃO DE ÁGUA DA REGIÃO METROPOLITANA DE SÃO PAULO 
JOSÉ RICARDO BUENO GALVÃO

\title{
AVALIAÇÃO DA RELAÇÃO PRESSÃO x CONSUMO, EM ÁREAS CONTROLẢDAS POR VÁLVULAS REDUTORAS DE PRESSÃO (VRPS) ESTUDO DE CASO: REDE DE DISTRIBUIÇÃO DE ÁGUA DA REGIÃO METROPOLITANA DE SẪO PAULO
}

\author{
Dissertação apresentada à Escola \\ Politécnica da Universidade de São Paulo \\ para obtenção do título de \\ Mestre em Engenharia \\ Área de Concentração: \\ Engenharia Hidráulica \\ Orientador: \\ Prof. Dr. Kamel Zahed Filho
}


Este exemplar foi revisado e alterado em relação à versão original, sob responsabilidade única do autor e com a anuência de seu orientador.

São Paulo, 7 de novembro de 2007.

Assinatura do autor

Assinatura do orientador

FICHA CATALOGRÁFICA

Galvão, José Ricardo Bueno

Avaliação da relação pressão $x$ consumo, em áreas controladas por válvulas redutoras de pressão (VRPs). Estudo de caso: rede de distribuição de água da Região Metropolitana de São Paulo / J.R.B. Galvão. -- ed.rev. -- São Paulo, 2007.

247p.

Dissertação (Mestrado) - Escola Politécnica da Universidade de São Paulo. Departamento de Engenharia Hidráulica e Sanitária.

1.Distribuição de água 2.Perdas de água 3.Válvulas I.Universidade de São Paulo. Escola Politécnica. Departamento de Engenharia Hidráulica e Sanitária Il.t. 


\section{DEDICATÓRIA}

Aos meus queridos pais, Rubens e Maria Izabel (in memorian), pelo amor, carinho, exemplo e sacrificios, para que eu seguisse meu caminho.

À minha amada esposa, Margareth, companheira de todos os momentos, especialmente, nos desafios. 


\section{AGRADECIMENTOS}

Ao Prof. Dr. Kamel Zahed Filho, pelo conhecimento transmitido, rigor técnico, desafios colocados e orientação para superá-los.

Ao meu chefe, Jairo Tardelli, pela compreensão e apoio.

À Escola Politécnica da Universidade de São Paulo e à Companhia de Saneamento Básico do Estado de São Paulo (Sabesp), que me propiciaram a participação nesse Programa de Mestrado.

Ao Prof. Dr. Luís Garcia, pela disponibilidade, atenção e direções apontadas.

Aos professores Monica e Podalyro, pela constante inspiração.

Ao pessoal do Waterworks and Sewerage Bureau of Nagoya City e da JICA, por me receberem com cortesia e pelo empenho em transmitirem seus conhecimentos, plantando a semente que me motivou a cursar este mestrado.

À Alta Administração da Sabesp, na pessoa da Malú, pela autorização para utilização de informações e pelo interesse manifestado na pesquisa. Ao Piza, com quem troquei idéias sobre o assunto, antes mesmo de definir o tema.

Ao meu colega, de Sabesp, Luís Fernando que, mais do que me ajudar na obtenção de dados, me ensinou a organizá-los. Aos meus colegas Alexandre, Cláudio e Genival, que me ajudaram na escolha das áreas de estudo.

Aos, também, colegas de Sabesp, Ailton, Marcelo Miki, Fátima, Irineu, Ricardo Chahin, Maria Alice, Hilton e Cícero, pelo apoio e incentivo e a todos os colegas que, de alguma forma, me ajudaram nessa empreitada.

Aos meus amigos Lúcio, Cristina, José Alves e Adriana, por compreenderem o nosso período de retiro temporário.

Aos meus queridos irmãos, que mesmo geograficamente distantes, estão sempre próximos.

À minha tia Hilda, que sempre me apoiou.

E, finalmente, a DEUS, pelo dom da vida. 
"Cognoscendi studium homini dedit Deus ejus torquendi gratia."

O desejo de conhecer foi dado por Deus ao homem para seu tormento.

(Michel de Montaigne) 


\section{RESUMO}

O presente trabalho investiga o efeito da redução de pressão em rede de distribuição de água, provocada pela instalação de válvulas redutoras de pressão (VPRs), no consumo médio total medido em ligações de água, localizadas em áreas sob influência daquele equipamento. Foi feito um levantamento no estado da arte em gestão de sistemas de abastecimento de água, com ênfase no controle de perdas, focado na gestão de pressão. Para se avaliar a possível redução de consumo, foi desenvolvida uma metodologia estatística, baseada em critérios de filtragem de dados de amostra e em testes paramétricos de hipóteses. O estudo de caso foi feito na Região Metropolitana de São Paulo (RMSP), utilizando sistema de informações geográficas (SIG), que permitiu o relacionamento de limites geográficos, com informações de consumo, através da integração com um sistema de informações comerciais, onde foi possível a obtenção de dados de consumos individuais, de ligações de água. Foram comparados os consumos, antes e depois da implementação de VRPs, com a correspondente redução de pressão, em áreas controladas por VRP e em áreas testemunha (sem influência da redução de pressão), através da realização de testes paramétricos de hipóteses. Foram, ainda, comparadas a variação no consumo médio das áreas de VRP, com a variação no consumo médio das áreas testemunha. Os resultados obtidos indicam que, embora tenha ocorrido uma tendência de redução no consumo de algumas áreas pesquisadas, esta redução não pode ser atribuída à implementação das VRPs.

Palavras-chave: Distribuição de água. Perdas de Água. Válvula redutora de pressão. Relação Pressão x Consumo. 


\section{ABSTRACT}

The following study investigates reduction in average costumers' consumption due to pressure reduction in water distribution systems, trough installation of pressure reducing valves (PRVs). A research on the state of art on water distributions systems management techniques was carried out, emphasizing water-loss control aspects, with focus on pressure management techniques. A statistical methodology based upon data filtering criteria and on statistical tests of hypothesis was developed to assess a possible effect in the water consumption reduction, for sample areas water consumption data. A case study was carried out in the Metropolitan Region of Sao Paulo (MRSP) using a Geographic Information System (GIS).

Relationship between the geographical study areas limits and the costumers' water consumption information was made by through use of GIS tools. Information on individual customers' water connections were retrieved from a commercial information data base system. Comparisons between average water consumption before and after PRVs initial operation were carried out. Same comparisons were applied in testimony areas (water distribution areas not submitted to water pressure reduction), in similar conditions to PRVs controlled areas. These comparisons were verified trough statistical parametric tests of hypothesis. The results showed that, despite of a tendency of lowering average water consumption in some of the researched areas it was not confirmed the influence of water pressure reduction on it.

Keywords: Water Distribution. Water-loss. Pressure Reduction Valves. Pressure : Consumption Relationship. 


\section{APRESENTAÇÃO}

Engenheiro Civil, José Ricardo Bueno Galvão, o autor, atua, desde 2000, no planejamento de ações para controle de perdas de água, na Companhia de Saneamento Básico do Estado de São Paulo (Sabesp).

Com a presente pesquisa, tem a intenção de apresentar um dos primeiros estudos, que se conhece, baseado em dados reais de consumo, avaliando o efeito da instalação de válvulas redutoras de pressão (VRPs) no consumo médio de ligações de água sob influência da redução na pressão de distribuição de água, implementada, em áreas caracterizadas como de abastecimento indireto (uso de caixa d'água pelos consumidores).

Com esse trabalho, se intenciona colocar alguma luz sobre um ponto controverso, que paira sobre a utilização daquele equipamento, como instrumento para redução das perdas de água através de vazamentos, no que tange a uma possível redução no faturamento das companhias que operam sistemas de distribuição de água.

Os que alegam uma redução no consumo total medido, em áreas sob influência de VRP, baseiam seus argumentos na hipótese de que a redução da pressão, junto ao ponto de consumo, induziria a uma redução involuntária dos consumos das ligações de água. Sua argumentação é a de que os propalados benefícios econômicos, advindos da redução do volume perdido através de vazamentos, estariam comprometidos pelo efeito provocado na redução de faturamento.

Como não se conhecem estudos, mais detalhados, com essa finalidade específica, em áreas que possuem a característica de abastecimento indireto, caso da Região Metropolitana de São Paulo, esta pesquisa pode contribuir para que sejam dirimidas algumas dúvidas existentes e para auxiliar a tomada de decisão nos estudos para instalação desse tipo de equipamento. 


\section{RESUMO EXECUTIVO}

\section{INTRODUÇÃO}

A utilização de válvulas redutoras de pressão (VRPs) como ferramenta para o controle de perdas, em redes de distribuição de água, vem sendo recomendada, por especialistas em gestão de sistemas de abastecimento de água, como a mais eficaz e com retornos mais rápidos, das ações para o controle de perdas reais, dentre as ações mais conhecidas.

Dessa forma, esse equipamento vem sendo instalado, em larga escala, em diversos sistemas de distribuição de água.

No entanto, ao mesmo tempo em que os especialistas recomendam sua utilização, alguns setores ligados às companhias que operam sistemas de distribuição de água, levantaram a suspeita de que a redução de pressão de abastecimento, provocada pela instalação de VRPs, poderia estar causando uma redução no faturamento dessas companhias, conseqüência de uma possível redução no consumo geral das ligações de água, localizadas no interior dessas áreas controladas por VRP.

\section{OBJETIVO}

O objetivo desta pesquisa é o de investigar o efeito da redução de pressão, provocada pela implementação de válvulas redutoras de pressão (VRPs), no consumo total médio, medido nas ligações de água localizadas no interior de áreas controladas por VRP.

\section{DESENVOLVIMENTO}

Para a consecução dos objetivos da pesquisa, foi desenvolvida uma metodologia, baseada na filtragem de dados de consumo, em áreas selecionadas para a 
pesquisa, e em análises estatísticas, elaboradas através de testes paramétricos de hipóteses.

Dessa forma, foram selecionadas 27 áreas controladas por VRP (sendo dezessete controladas por VRP com saída fixa de pressão e dez controladas por VRP com controle automático de pressão) e 27 áreas testemunha (sem influência da redução de pressão), sendo uma área testemunha para cada área controlada por VRP, totalizando 54 áreas.

A seleção das áreas seguiu os seguintes critérios: a) cada VRP escolhida deveria ter permanecido em operação, sem qualquer interrupção, pelo período mínimo de dois anos; b) a data de entrada em operação, das VRPs, deveria ser posterior a junho de 2002, por motivos de disponibilidade de dados ativos de consumo no sistema comercial.

Selecionadas as áreas de VRP, foi utilizado um sistema de informações geográficas (SIG), localizando os limites geográficos de cada área de VRP e selecionando as áreas testemunha, para cada uma das áreas. Com esses limites selecionados, foi utilizada a ferramenta do SIG que faz a integração com o banco de dados do sistema comercial, sendo levantadas as identificações de todas as ligações localizadas no interior de cada uma das áreas e, posteriormente, os consumos de cada uma dessas ligações, nas datas estabelecidas para cada VRP.

Dessa forma, foram levantados os seguintes consumos: $v 1=$ consumo no mês anterior à entrada em operação, de cada VRP; v2 = consumo no mês posterior à entrada em operação, de cada VRP; 33 = consumo do mesmo mês de v1, no ano seguinte; v4 = consumo do mesmo mês de v2, no ano seguinte; e M6 = consumo médio nos seis meses anteriores à implantação de cada VRP.

O conjunto de 54 áreas foi subdividido em três grupos básicos: 1 - conjunto das áreas de VRP + áreas testemunha; 2 - conjunto das áreas de VRP; e 3 - conjunto das áreas testemunha.

Foi feita, então, uma subdivisão desses conjuntos, gerando os conjuntos: 4 - áreas controladas por VRP com saída fixa de pressão; 5 - áreas controladas por VRP com controle automático de pressão; 6 - áreas testemunha de áreas de VRP com saída 
fixa de pressão; e 7 - áreas testemunha de áreas controladas por VRP com controle automático de pressão.

Como foi constatada a presença de grandes consumidores, nas áreas selecionadas para a pesquisa, que poderiam influir no resultado geral dos conjuntos de áreas, foi estabelecida mais uma subdivisão, estratificando os conjuntos 4.1 a 4.3, 5.1 a 5.3, 6.1 a 6.3 e 7.1 a 7.3 , pelo número de economias (unidades de consumo de serviços de saneamento) por ligação, lembrando que, em condomínios, por exemplo, uma única ligação abastece diversas economias.

Dessa forma, foram avaliados, ainda, os conjuntos com até 12 economias por ligação; com até três economias por ligação; e com uma única economia por ligação.

Dos dados de consumo, organizados para cada uma das áreas e para cada configuração de análise apresentada, foi estabelecido que as comparações de diferenças de consumo (antes - depois) seriam feitas entre o consumo médio nos seis meses anteriores à implementação de cada VRP e a média dos consumos v2, v3 e v4, posteriores à implementação de cada VRP.

Estabelecidas as divisões mencionadas, resultaram 19 grupos de análise, cada um com sua respectiva série de dados de consumo, a partir da filtragem do banco de dados levantado no sistema comercial.

Com esses grupos estabelecidos, foram feitos testes de consistência dos dados, utilizando-se a técnica de "box plot com grades", sendo considerados outliers e descartados das análises, de cada um dos 19 grupos, as áreas cuja diferença de média de consumo (antes - depois), se situou abaixo da grade interna inferior, do box plot, ou acima da sua grade interna superior.

O resultado desses testes de consistência encontram-se resumidos no Quadro 1. 
Quadro 1 - Sumário dos resultados das análises de consistência (box plot)

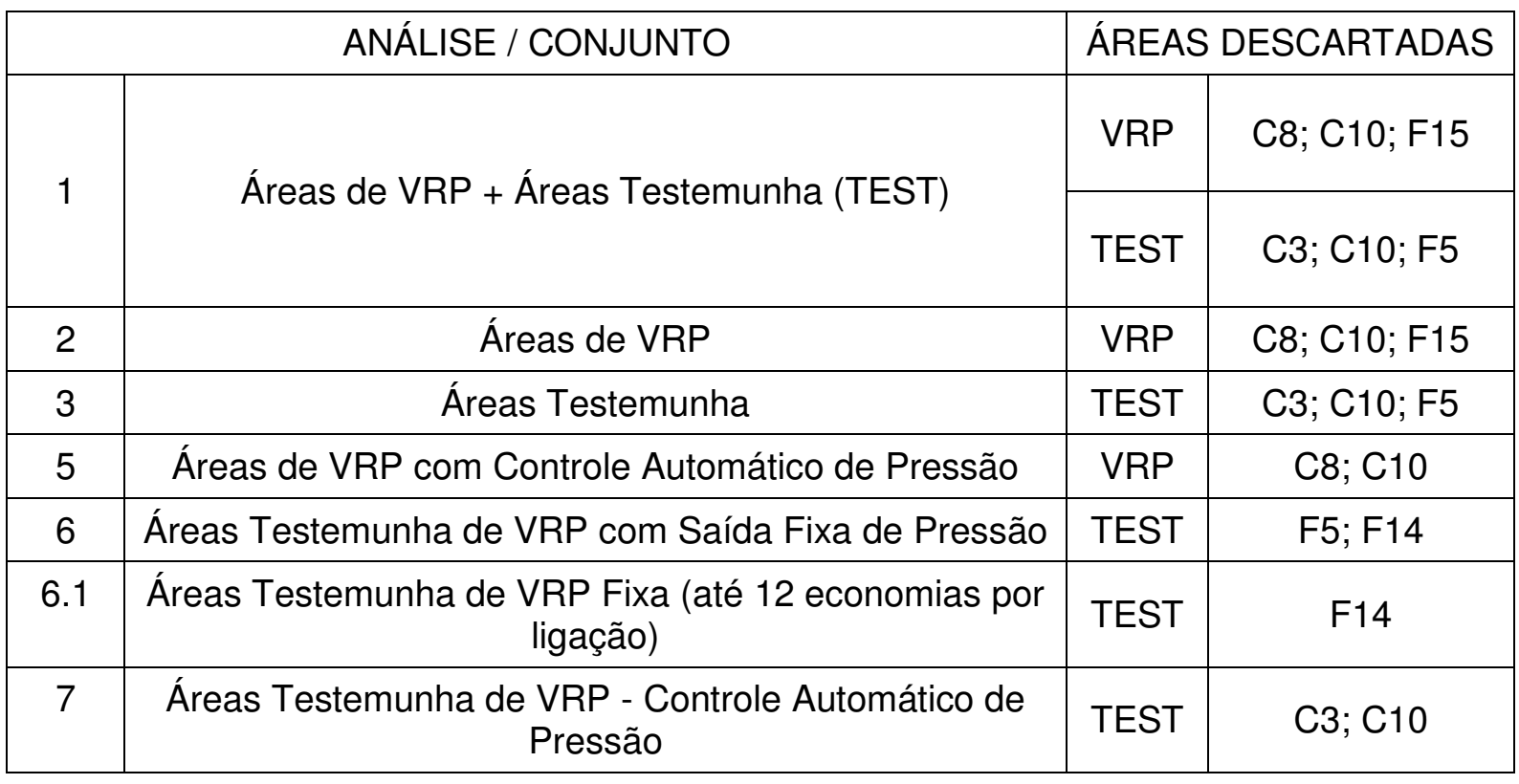

Nos demais conjuntos de áreas, não foram identificados outliers.

Com as séries de dados consistidas, foram feitos testes comparativos, por conjunto de área, na situação antes da implementação da VRP $\mathrm{x}$ depois da implementação da VRP, constituindo-se de testes de hipóteses entre pares de diferenças de médias, ou testes de t-pareado.

O resultado desses testes é apresentado, resumidamente, no Quadro 2.

Quadro 2 - Resumo dos resultados obtidos nos testes de hipóteses

\begin{tabular}{|l|l|c|c|}
\hline \multicolumn{2}{|c|}{ ANÁLISE } & $\begin{array}{c}\text { Resultados: o consumo } \\
\text { antes x depois }\end{array}$ & $\begin{array}{c}\text { Nível de } \\
\text { Significância }\end{array}$ \\
\hline 1 & Médias áreas de VRP + testemunha & Reduziu & $1 \%$ \\
\hline 2 & Médias áreas de VRP & Reduziu & $1 \%$ \\
\hline 3 & Médias áreas testemunha & Não Variou & $5 \%$ \\
\hline 4 & Médias áreas de VRP Saída Fixa & Não Variou & $5 \%$ \\
\hline 4.1 & VRP Fixa (até 12 economias por ligação) & Reduziu & $5 \%$ \\
\hline 4.2 & VRP Fixa (até 3 economias por ligação) & Reduziu & $5 \%$ \\
\hline 4.3 & VRP Fixa (1 economia por ligação) & Reduziu & $5 \%$ \\
\hline 5 & Médias áreas - VRP Controle Automático & Não Variou & $5 \%$ \\
\hline
\end{tabular}


(continuação)

\begin{tabular}{|l|l|c|c|}
\hline \multicolumn{2}{|c|}{ ANÁLISE } & $\begin{array}{c}\text { Resultados: o consumo } \\
\text { antes x depois }\end{array}$ & $\begin{array}{c}\text { Nível de } \\
\text { Significância }\end{array}$ \\
\hline 5.1 & $\begin{array}{l}\text { VRP Autom. (até 12 economias por } \\
\text { ligação) }\end{array}$ & Não Variou & $5 \%$ \\
\hline 5.2 & VRP Autom. (até 3 economias por ligação) & Não Variou & $5 \%$ \\
\hline 5.3 & VRP Autom. (1 economia por ligação) & Não Variou & $5 \%$ \\
\hline 6 & Médias áreas testemunha FIXA & Reduziu & $5 \%$ \\
\hline 6.1 & A T FIXA (até 12 economias por ligação) & Reduziu & $1 \%$ \\
\hline 6.2 & A T FIXA (até 3 economias por ligação) & Reduziu & $5 \%$ \\
\hline 6.3 & A T FIXA (1 economia por ligação) & Reduziu & $1 \%$ \\
\hline 7 & Médias áreas testemunha AUTOMÁTICA & Não Variou & $5 \%$ \\
\hline 7.1 & $\begin{array}{l}\text { A T AUTOM. (até 12 economias por } \\
\text { ligação) }\end{array}$ & Não Variou & $5 \%$ \\
\hline 7.2 & A T AUTOM. (até 3 economias por ligação) & Não Variou & $5 \%$ \\
\hline 7.3 & A T AUTOM. (1 economia por ligação) & Não Variou & $5 \%$ \\
\hline
\end{tabular}

Após as análises comparando cada conjunto de áreas na situação antes $\mathrm{x}$ depois da implementação das VRPs, foram feitas análises comparativas entre cada conjunto de áreas de VRP com os respectivos conjuntos de áreas testemunha.

Para essas análises, também, foram utilizados testes de hipóteses, só que, diversamente das análises antes $\mathrm{x}$ depois, testes de hipóteses para médias de duas amostras de populações diferentes. No caso, médias das diferenças de consumo médio (antes - depois).

O resultado desses testes de comparação entre áreas de VRP $\mathrm{x}$ áreas testemunha, estão sumarizados no Quadro 3.

Quadro 3 - Resumo dos resultados dos testes de hipóteses entre diferenças de consumo de áreas de VRP e diferenças de consumo de áreas testemunha

\begin{tabular}{|c|l|c|c|}
\hline \multicolumn{2}{|c|}{ ANÁLISE } & $\begin{array}{c}\text { Resultados: Consumo } \\
\text { nas Áreas } \\
\text { de VRP x Testemunha }\end{array}$ & $\begin{array}{c}\text { Nível de } \\
\text { Significância }\end{array}$ \\
\hline 8 & Testemunha $\times$ VRP Fixa & Mesma Variação & $5 \%$ \\
\hline 8.1 & Testemunha $\times$ VRP Fixa (até 12 econ./lig.) & Mesma Variação & $5 \%$ \\
\hline 8.2 & Testemunha $\times$ VRP Fixa (até 3 econ./lig.) & Mesma Variação & $5 \%$ \\
\hline
\end{tabular}

(continua) 
(continuação)

\begin{tabular}{|c|l|c|c|}
\hline \multicolumn{2}{|c|}{ ANÁLISE } & $\begin{array}{c}\text { Resultados: Consumo } \\
\text { nas Áreas } \\
\text { de VRP x Testemunha }\end{array}$ & $\begin{array}{c}\text { Nível de } \\
\text { Significância }\end{array}$ \\
\hline 8.3 & Testemunha x VRP Fixa (1 econ./lig.) & Mesma Variação & $5 \%$ \\
\hline 9 & Testemunha x VRP Controle Automático & Mesma Variação & $5 \%$ \\
\hline 9.1 & $\begin{array}{l}\text { Testemunha x VRP Autom. (até 12 econ. } \\
\text { por ligação) }\end{array}$ & Mesma Variação & $5 \%$ \\
\hline 9.2 & $\begin{array}{l}\text { Testemunha x VRP Autom. (até 3 econ. por } \\
\text { ligação) }\end{array}$ & Mesma Variação & $5 \%$ \\
\hline 9.3 & $\begin{array}{l}\text { Testemunha x VRP Autom. (1 econ. por } \\
\text { ligação) }\end{array}$ & Mesma Variação & $5 \%$ \\
\hline 10 & $\begin{array}{l}\text { Áreas Testemunha x Áreas de VRP } \\
\text { Mesma Variação }\end{array}$ \\
\hline
\end{tabular}

\section{CONCLUSÕES}

Nas $48^{1}$ áreas analisadas, em conjunto, o consumo médio total das ligações apresentou redução, após as datas de entrada em operação das VRPs. No entanto, essa redução não pode ser atribuída à instalação das VRPs.

Não é possível afirmar que a redução de pressão de distribuição de água, provocada pela instalação de VRPs, tenha influenciado o consumo medido nas ligações de água, localizadas no interior dessas áreas.

\footnotetext{
${ }^{1}$ Das 54 áreas iniciais, os dados de consumo de seis foram considerados outliers e descartados desse conjunto.
} 


\section{LISTA DE ILUSTRAÇÕES}

Figura 2.1 - Perfil de Perdas da RMSP - 1993 .......................................... 31

Figura 2.2 - Balanço Hídrico das 'Melhores Práticas' - IWA ........................... 34

Figura 2.3 - Perfil de Perdas - Abordagem Atual ........................................ 36

Figura 2.4 - Perfil das Perdas de Faturamento …………............................. 37

Figura 2.5 - Síntese das ações para o controle e redução de perdas reais ..... 38

Figura 2.6 - Os quatro componentes de uma política de gerenciamento de perdas reais, bem sucedida ................................................... 40

Figura 2.7 - Ilustrações de válvulas redutoras de pressão ............................. 52

Figura 2.8 - Evolução do número de VRPs instaladas na RMSP ................... 55

Figura 2.9 - Instalação hidráulica com abastecimento indireto ....................... 56

Figura 2.10 - Instalação hidráulica com abastecimento direto ………............... 57

Figura 2.11 - Curva de erros em hidrômetro ………………………………...... 63

Figura 2.12 - Desenho esquemático do conjunto caixa d'água + torneira de bóia

Figura 2.13 - Vazão medida antes e após redução de pressão aplicada por VRP

Figura 2.14 - Distribuição da quantidade de ligações, na RMSP, conforme o tipo de uso - março de 2007

Figura 2.15 Distribuição do volume medido em ligações, na RMSP, conforme o tipo de uso - março de 2007

Figura 2.16 Principais usos residenciais na RMSP - 2001 ........................... 68

Figura 2.17 Curvas de consumo máximo, médio e mínimo - Setor Jaçanã ... 71

Figura 3.1 - Limites da área da VRP F1, sem layers ................................... 76

Figura 3.2 - Limites da área da VRP F1, com layer de arruamento ................ 76 
Figura 3.3 - Limites da área da VRP F1, com layer de imagem de satélite .... 77

Figura 3.4 - Percentual do total de ligações, por tipo de área ......................... 80

Figura 3.5 - Percentual do total de economias, por tipo de área ….................. 80

Figura 3.6 - Média de economias por ligação, por tipo de área ........................ 81

Figura 3.7 - Consumo médio total, antes $x$ depois da redução de pressão implementada nas áreas controladas por VRP, selecionadas ....

Figura 3.8 - Consumo médio total, antes $x$ depois da redução de pressão implementada, nas áreas testemunha de áreas controladas por VRP

Figura 3.9 - Comparação das diferenças de consumo (antes - depois), entre as áreas de VRP e as áreas testemunha

Figura 3.10 - Exemplo de gráfico de box plot, com grades

Figura 3.11 - Apresentação das séries de dados de diferenças de consumo box plot

Figura 3.12 - Representação gráfica de teste de hipóteses

Figura 3.13 - Gráfico do box plot, para a Análise 2 - Áreas Controladas por VRP

Figura 4.1 - Localização do Estado de São Paulo, no Mapa do Brasil, e da RMSP, no Mapa do Estado de São Paulo

Figura 4.2 - Mapa com os municípios que formam a RMSP

Figura 4.3 - Localização, na RMSP, das áreas de VRP em análise 100 


\section{LISTA DE QUADROS}

Quadro 2.1 - Dados de consumo de água médio, na RMSP (ano base: 2005). 69

Quadro 3.1 - Relação de áreas de VRP e testemunhas, selecionadas para o estudo

Quadro 3.2 - Análises dos dados de consumo médio total das ligações

Quadro 3.3 - Exemplo de planilha de cálculo de box plot

Quadro 3.4 - Exemplo de planilha de cálculo de teste de hipóteses

Quadro 3.5 - Análises comparativas entre áreas controladas por VRP e suas respectivas áreas testemunha

Quadro 4.1 - Características do abastecimento de água na RMSP

Quadro 5.1 - Sumário dos resultados das análises de consistência (box plot) 101

Quadro 5.2 - Resumo dos resultados obtidos nos testes de hipóteses 104

Quadro 5.3-Resumo dos resultados dos testes de hipóteses entre consumos de áreas de VRP e consumos de áreas testemunha . 106 


\section{LISTA DE ABREVIATURAS E SIGLAS}

ABNT

Autom.

AWWA

AWWARF

C1 a C10

C1 Test a C10 Test

CSI

DMA

EMPLASA

F1 a F17

F1 Test a F17 Test

GIS

IPT

IQR

IWA

LYSA

NBR

Ofwat

PURA

RGI

RMSP

SIG

Signos

un.

UN

USEPA

VRP

WMA

WLTF
Associação Brasileira de Normas Técnicas

abreviatura de automática

American Water Works Association

AWWA Research Foundation

Sigla das áreas de VRP com controle automático de pressão

Sigla das áreas testemunha de VRP automática

Sistema Comercial, Serviços e Informação, da Sabesp

District Metered Area

Empresa Paulista de Planejamento Metropolitano S.A.

Sigla das áreas de VRP com controle fixo de pressão

Sigla das áreas testemunha de VRP fixa

Geographic Information System

Instituto de Pesquisas Tecnológicas

Intervalo Interquartil

International Water Association

Lyonaisse dês Eaux Servicés Associes

Norma Brasileira

Office of Water Service

Programa de Uso Racional da Água

Registro das Ligações de Água (identificação)

Região Metropolitana de São Paulo

Sistema de Informações Geográficas

Sistema de Informações Geográficas no Saneamento, utilizado pela Sabesp

unidade

Unidade de Negócio

United States Environment Protection Agency

Válvula Redutora de Pressão

Waste Meter Area

Water Loss Task Force (no glossário: Força-Tarefa para

Redução de Perdas - IWA) 


\section{LISTA DE SÍMBOLOS}

$\mathrm{Di}$

$\mathrm{K}_{1}$

$\mathrm{K}_{2}$

$\mathrm{K}_{3}$

M6

$Q_{\max }$

$Q_{\min }$

$Q_{n}$

$\mathrm{Q}_{\mathrm{t}}$

v1

v2

v3

v4

$\mathrm{Xi}$

$Y i$

diferença entre o consumo médio antes e o consumo médio após a redução de pressão de distribuição

coeficiente do dia de maior consumo

coeficiente da hora de maior consumo

coeficiente da hora de menor consumo

média de consumo nos seis meses anteriores à entrada em operação da VRP

vazão máxima, ou de sobrecarga

vazão mínima

vazão nominal, ou permanente

vazão de transição

consumo no mês anterior ao mês de entrada em operação de cada VRP

consumo no mês posterior ao mês de entrada em operação de cada VRP

consumo no mesmo mês (jan, fev, etc.) do mês anterior à entrada em operação da VRP, no ano seguinte consumo no mesmo mês (jan, fev, etc.) do mês posterior à entrada em operação da VRP, no ano seguinte consumo médio antes da redução de pressão de distribuição consumo médio após a redução de pressão de distribuição 


\section{SUMÁRIO}

OBJETIVO

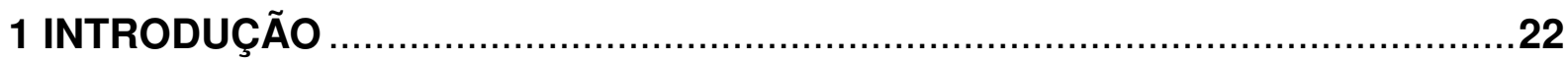

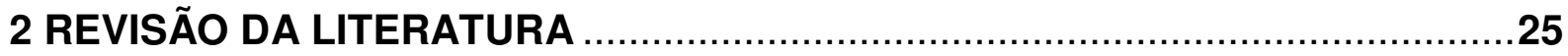

2.1 GERENCIAMENTO DOS RECURSOS HÍDRICOS …................................25

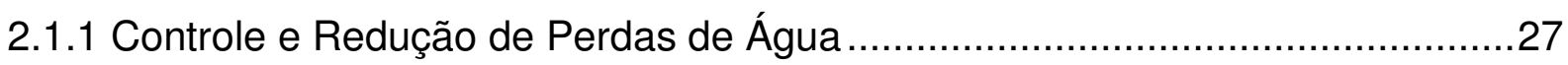

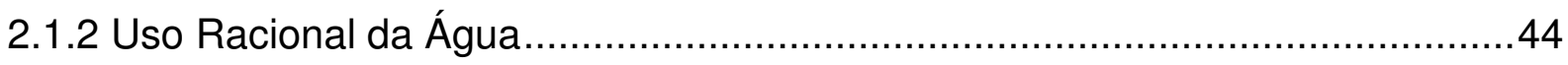

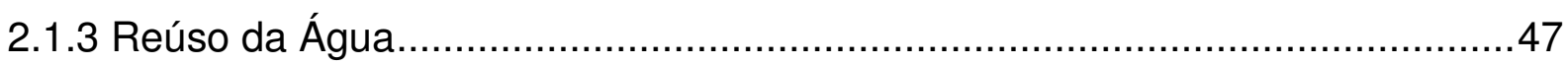

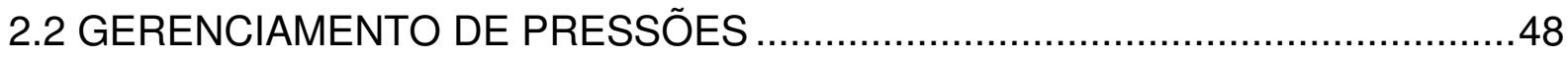

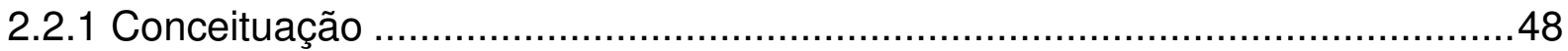

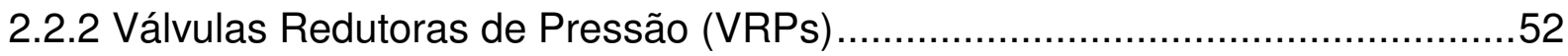

2.2.3 Efeitos da Redução de Pressão, no Consumo das Ligações de Água .............56

2.3 DISPOSITIVOS QUE INFLUENCIAM O REGISTRO DO CONSUMO DE ÁGUA .58

2.3.1 Configuração de Sistemas de Distribuição em outros Países .........................59

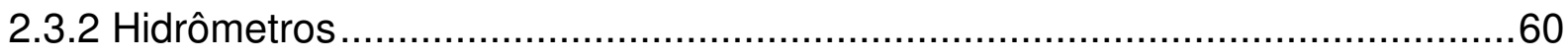

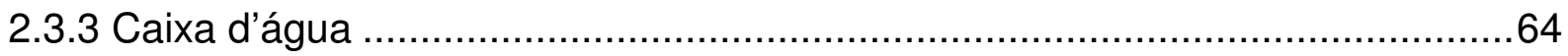

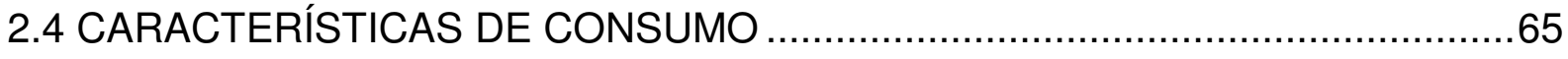

2.5 SISTEMAS DE INFORMAÇÕES GEOGRÁFICAS (SIG) ................................71

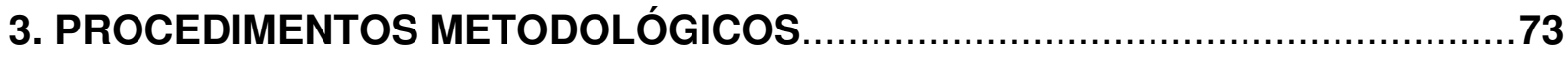

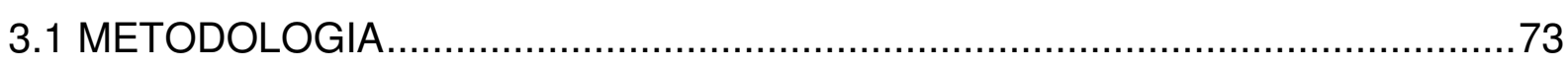

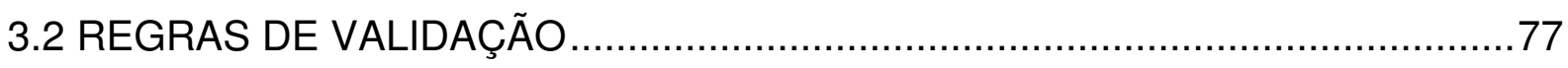

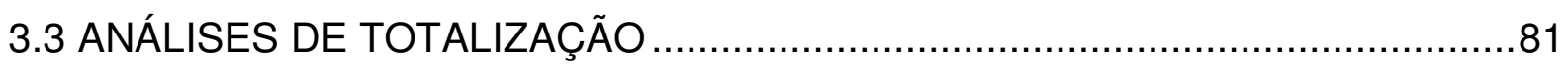

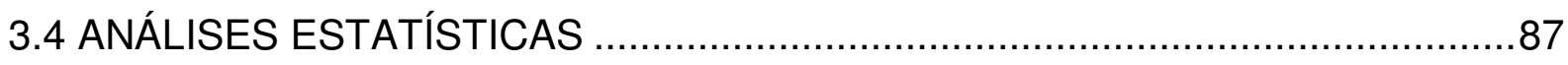

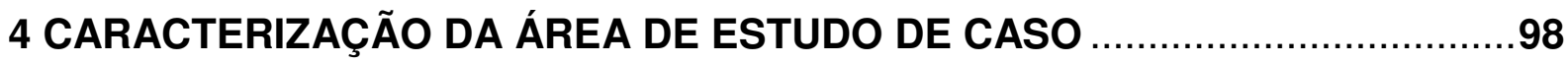

5 RESULTADOS

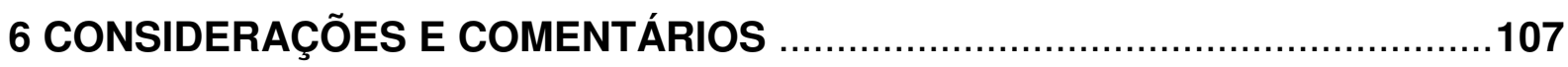

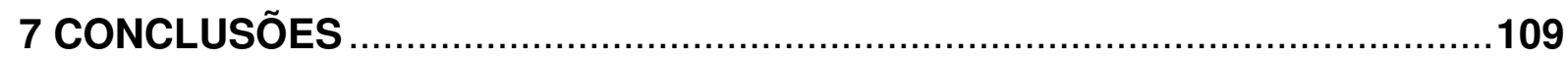




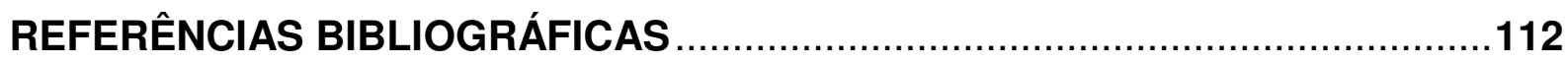

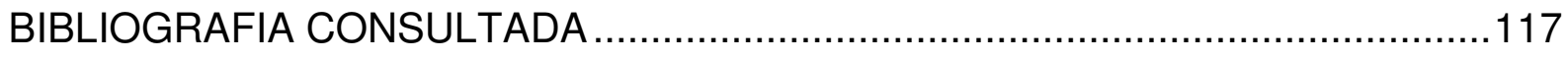

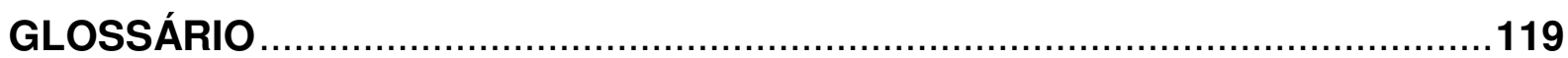

APÊNDICE A: TOTALIZAÇÕES DE CONSUMO ...............................................125

APÊNDICE B: ANÁLISES DE CONSISTÊNCIA …...........................................193

APÊNDICE C: PLANILHAS COM OS TESTES DE HIPÓTESES ........................218

APÊNDICE D: TESTES DE HIPÓTESES (VRP x TESTEMUNHA) ......................238 


\section{OBJETIVO}

O objetivo do trabalho proposto é o de verificar se os volumes medidos em consumidores, localizados em algumas áreas com rede de distribuição controlada por Válvula Redutora de Pressão (VRP), foram afetados pela redução de pressão implementada, através de um estudo de caso na Região Metropolitana de São Paulo (RMSP). 


\section{INTRODUÇÃO}

Para o atendimento das necessidades de água, para alimentação, higiene, saneamento e outros usos (domésticos, comerciais e industriais) das populações que habitam as cidades, é necessária uma infra-estrutura de instalações e tubulações, conhecida por sistema de abastecimento de água.

Gomes (2004) descreve os sistemas de abastecimento de água como um conjunto de equipamentos, obras e serviços voltados para o suprimento de água a comunidades, para fins de consumo doméstico, industrial e público.

A configuração básica dos sistemas de abastecimento de água, como conhecidos hoje, remonta aos anos 1700 - 1450 a.C. (ALEM SOBRINHO; MARTINS, 2004), tendo sofrido aperfeiçoamentos tecnológicos, como nos materiais e na forma de pressurização do sistema.

Dessa forma, um sistema de abastecimento tradicional, com algumas variações, dadas as características inerentes à localização de cada cidade, é formado pelos seguintes componentes: manancial, captação, estação elevatória, adutora de água bruta, estação de tratamento de água, adutora de água tratada, reservatório e rede de distribuição (GOMES, 2004; TSUTIYA, 2004).

Tomando o primeiro componente dos sistemas de abastecimento, os mananciais, pode-se afirmar que é crescente a preocupação, em âmbito mundial, com relação à disponibilidade dos recursos hídricos na quantidade e qualidade necessária ao abastecimento humano, frente ao crescimento das necessidades de água e à deterioração da qualidade de boa parte dos recursos hídricos.

Nesse ambiente de restrição hídrica e com demanda por água crescente, passou a ser avaliada como alternativa e/ou complemento aos estudos de novos mananciais e sistemas produtores de água, que é a primeira solução aventada quando se avalia o problema da ótica do abastecimento, a chamada Gestão da Demanda, que busca soluções para o problema de restrição hídrica, pela ótica do consumo de água. Quanto a esse aspecto, Gumbo e Van Der Zaag (2001, p.1 - tradução nossa) ponderam: 
[...] o argumento é sonoro e convincente: se existe restrição hídrica, não limite a solução apenas às opções pelo lado do abastecimento (desenvolvimento do próximo sistema produtor), mas considere também as opções pelo lado da demanda, como minimização das perdas de água e influência na demanda [por água], buscando níveis de consumo mais desejáveis, através de medidas estruturais (p.e. [...] reciclagem e reúso de água) e não-estruturais (p.e. campanhas educativas, restrições de uso e política tarifária).

Nesse contexto, surge a figura da conservação dos recursos hídricos, que pressupõe desde a criação de áreas de preservação de mananciais (caráter preventivo) até ações de caráter corretivo como ações para a disseminação do uso racional da água, visando redução nos níveis de consumo, ações demandadas pela Sociedade, que cobra das companhias que operam sistemas de distribuição de água o uso responsável desses recursos e se traduzem na adoção de ações que visam a redução e o controle das perdas em sistemas de distribuição de água e em ações que buscam a reutilização da água.

É nesse âmbito, mais geral, da conservação dos recursos hídricos, que está inserido o objeto da pesquisa proposta.

Mais precisamente, dentre as ações de melhores práticas operacionais, recomendadas para a otimização da operação de sistemas de distribuição de água, destaca-se $\circ$ gerenciamento de pressões na rede de distribuição. Esse gerenciamento de pressões, de maneira mais freqüente, tem se traduzido na vertente de redução de pressões excessivas ou desnecessárias, resultando na instalação de válvulas redutoras de pressão (VRPs).

No meio técnico, apesar da literatura especializada afirmar que em sistemas com abastecimento indireto (uso de reservatório por parte dos consumidores) a redução de pressão não afeta o nível de consumo (FARLEY; TROW, 2003; THORNTON, 2002), como não são conhecidos estudos técnicos mais detalhados que comprovem essa afirmação, existe uma desconfiança de que essa redução apresente, sim, um efeito colateral de redução no consumo, registrado nos hidrômetros dos consumidores instalados nas áreas onde a pressão de abastecimento foi reduzida.

No contexto apresentado, levando-se em consideração a configuração da rede de distribuição, das ligações prediais e das instalações hidráulicas nos consumidores, ainda não se conhecem estudos, com dados reais de consumo, que avaliem, com 
maior rigor técnico, essa influência da redução de pressão no consumo médio das ligações de água, localizadas em áreas sob influência de VRP.

Dessa forma, foi feita uma comparação do consumo médio total, em áreas com a pressão da rede de distribuição controlada por VRP, antes e depois da implementação da redução de pressão, sendo feita, ainda, uma comparação entre as áreas com e sem VRP (áreas testemunha, que são áreas localizadas nas proximidades de cada VRP, mas que não se encontram sob influência de redução de pressão no abastecimento). 


\section{REVISÃO DA LITERATURA}

Neste capítulo, para se situar o objeto da pesquisa, no campo do conhecimento técnico relacionado ao abastecimento de água, são apresentados conceitos e resultados de estudos que possuem interface com o tema da pesquisa.

Dessa forma, são abordados: os conceitos, mais genéricos, do gerenciamento dos recursos hídricos; os conceitos, mais específicos, do gerenciamento de pressões em redes de distribuição de água; aprofundando, um pouco mais, para se chegar ao tema específico da pesquisa, uma apresentação de fatores que influenciam no registro do consumo de água; uma abordagem das características de consumo; e, finalmente, uma visão superficial em sistemas de informações geográficas (SIGs), ferramenta utilizada nos levantamentos para a execução da pesquisa.

\subsection{GERENCIAMENTO DOS RECURSOS HÍDRICOS}

Neste item, procura-se fornecer um panorama, mais abrangente, de gerenciamento dos recursos hídricos, aprofundando-se, um pouco mais, nos conceitos e ações da atividade de controle e redução de perdas de água, apresentando, ainda, um panorama sobre os conceitos relacionados às ações de uso racional da água e uma breve descrição dos conceitos de reúso da água.

Frente à escassez de recursos naturais e ao crescimento da demanda por água, o gerenciamento adequado dos recursos hídricos deve incorporar os conceitos de conservação dos recursos hídricos.

Baumann et al. (1979 apud TATE, 1991) define conservação dos recursos hídricos como qualquer redução, socialmente benéfica, no uso ou nas perdas de água. Com base nessa definição, Tate (1991- tradução nossa) afirma: "Colocada dessa forma, a eficiência no uso dos recursos hídricos tem importância central na conservação [dos recursos hídricos]". Aprofundando-se nessa questão, Tate (1991 - tradução nossa) continua:

[...] a eficiência no uso dos recursos hídricos tem um papel bem definido a desempenhar no desenvolvimento sustentável, em outras palavras, a 
utilização dos recursos da Terra por seus habitantes atuais, ao mesmo tempo em que garanta que as gerações futuras tenham capacidade [de recursos] suficiente para atender suas próprias necessidades. Aprimorar a eficiência no uso dos recursos [naturais] se constitui num meio de alcançar as metas de desenvolvimento sustentável.

A forma e importância como são encaradas e empregadas as ações para busca de eficiência no uso dos recursos hídricos varia bastante entre as regiões e países e através do tempo, dependendo de fatores: geográficos (a disponibilidade de água condiciona os padrões de consumo); condições econômicas (sempre conduzem a um nível maior ou menor de uso eficiente da água); e condições sociais (podem, também, ser importantes ao se avaliar o uso eficiente dos recursos hídricos) (TATE, 1991).

Quando discorre, brevemente, sobre as perspectivas históricas do gerenciamento dos recursos hídricos, Tate (1991) afirma que a mudança de foco da busca de novas fontes de abastecimento para a gestão da demanda é visível em muitas partes do mundo. Considera, ainda, que, olhando-se da perspectiva histórica, fica claro que na maior parte do tempo o gerenciamento dos recursos hídricos manteve seu foco na manipulação das fontes naturais de recursos hídricos direcionando-os para onde fossem necessários e que, nesse contexto, o uso eficiente da água sempre ficou em segundo plano, com relação ao atendimento de todas as possíveis demandas para esse recurso natural. Só recentemente é que os gestores dos recursos hídricos vêm se preocupando em avaliar "como a demanda pode ser atendida sem 0 desenvolvimento de grandes fontes de abastecimento."

No documento "Como conservar os recursos hídricos e usá-los de maneira eficiente" a Agência de Proteção Ambiental dos Estados Unidos da América (USEPA) divide os usuários de água em dois grupos básicos: usuários dos sistemas de distribuição de água e operadores de sistema de distribuição de água.

Divide, ainda, as práticas de uso eficiente dos recursos hídricos em duas categorias: 1) Práticas de engenharia, baseadas em modificações em sistemas de engenharia, no bombeamento, ou em acessórios das instalações hidráulicas prediais, ou em procedimentos operacionais do sistema de distribuição; 2) Práticas comportamentais, baseadas em mudança de hábitos de consumo (USEPA, 2007). 
As conceituações apresentadas podem ser traduzidas em dois tipos de abordagem que têm o objetivo de conservação dos recursos hídricos: $1^{1}$ ) abordagem conhecida como controle de perdas nos sistemas de distribuição de água, que envolve diversos tipos de ações empreendidas pelas empresas que operam sistemas de distribuição; $2^{\mathrm{a}}$ ) abordagem conhecida por uso racional da água, que visa a gestão da demanda por água, por parte dos consumidores, incentivando um uso mais adequado e a minimização de desperdícios, com conseqüente redução nos níveis de consumo; essa abordagem utiliza, como ferramentas, a realização de cursos e campanhas educativas e incentiva $o$ desenvolvimento e utilização de equipamentos economizadores de água.

Deve-se destacar, ainda, que está se tornando cada vez mais comum, entre as empresas que operam sistemas de distribuição de água, pesquisas e experimentos visando o reuso da água, num primeiro momento, para fins não-potáveis.

\subsubsection{Controle e Redução de Perdas de Água}

Dada a escassez de recursos hídricos, na quantidade e qualidade exigidas para os diversos usos das populações, a Sociedade vem cobrando, das companhias de distribuição de água, o uso responsável desses recursos.

Com relação a esse aspecto, Farley e Trow (2003 - tradução nossa) afirmam que "perdas de água nas redes de distribuição, sempre o 'fantasma' dos engenheiros de operação, há tempos vêm sendo um tópico distinguido no gerenciamento da operação, mesmo em países com uma infra-estrutura bem desenvolvida e boas práticas operacionais".

Da mesma forma, Thornton (2002, p. 2 - tradução nossa) considera que "[...] muitos sistemas de abastecimento de água, altamente desenvolvidos, em países tecnologicamente avançados, sofrem de um problema traiçoeiro que desafia a sustentabilidade de longo prazo dos recursos hídricos, para o futuro: as perdas de água". 
Para ressaltar que a adoção de ações para o controle de perdas, em sistemas de abastecimento, é uma preocupação relativamente recente das operadoras desse tipo de sistema, Thornton (2002, p.2 - tradução nossa) afirma:

[...] Em anos passados, a disponibilidade aparentemente infinita de recursos hídricos na expansão de 'novos mundos' fez com que a perda de água fosse amplamente relegada. Com a água de fácil obtenção e relativamente barata, as perdas eram ignoradas pelas empresas de distribuição de água, ou assumidas como naturalmente inerentes à operação desse tipo de sistema. Com as demandas de populações crescentes, contudo, a conscientização da quantidade limitada dos recursos naturais e custos crescentes, por restrições de regulamentação e demandas dos consumidores, fizeram com que passasse a ser inimaginável continuar ignorando as perdas de água nesses sistemas.

Situando melhor a ocorrência do problema de perda de água, da experiência profissional deste autor e da busca na literatura especializada, pode-se afirmar que a quase totalidade das companhias de abastecimento de água concentra suas ações para redução e controle de perdas na sua infra-estrutura de distribuição, que compreende a rede de distribuição e as ligações prediais, pelo fato das perdas ocorrerem, majoritariamente, nessa parte do sistema.

Sobre esse aspecto, Thornton (2006 - informação verbal) ${ }^{1}$ afirma que, de fato, as perdas de água se concentram na rede de distribuição. Considera, ainda, que pelas características dos sistemas adutores (a montante dos reservatórios de distribuição) - altas vazões e altas pressões - na maioria das vezes, os vazamentos afloram rapidamente, sendo também reparados rapidamente, até pelas conseqüências mais graves que poderiam advir de vazamento nesse porte de tubulação.

Para transmitir uma idéia clara de perdas de água em sistemas de distribuição, Wallace (1987, p.3 - tradução nossa) sintetiza o problema da seguinte forma:

Colocado de maneira simplificada, o problema se divide em dois: 1) a água comprada ou produzida por uma empresa de distribuição de água, ou departamento, não chega até o seu destino na sua totalidade; e 2) uma parcela da água que chega ao seu destino nunca é remunerada [à empresa distribuidora].

\footnotetext{
${ }^{1}$ Informação fornecida por Julian Thornton, em Painel sobre Eficiência Operacional, no XVII Encontro Técnico da Associação dos Engenheiros da Sabesp (AESABESP). São Paulo, 2006.
} 
Nessa definição, estão representadas as duas divisões clássicas das perdas totais (diferença entre o volume de água entregue para distribuição e o volume de consumos de água autorizados, medidos e estimados) num sistema de distribuição: 1) as chamadas perdas reais (anteriormente chamadas de perdas físicas), compostas pelos volumes de água perdidos através de vazamentos e extravasamentos em reservatórios, de vazamentos nas tubulações e em peças especiais das redes de distribuição e de vazamentos nas ligações prediais, no trecho entre a rede de distribuição e o hidrômetro instalado no imóvel do consumidor; e 2) as chamadas perdas aparentes (também conhecidas por perdas comerciais e anteriormente chamadas de perdas não-físicas), que compreendem, basicamente: os volumes não registrados pelos medidores instalados nos consumidores, devidos à ocorrência de vazões abaixo da faixa de trabalho dos medidores (submedição) que podem ser decorrentes do efeito do conjunto caixa d'água e torneira de bóia, ou de defeitos, mau dimensionamento ou má instalação de medidores; os volumes de consumos não registrados devidos a falhas no processo de cobrança (erros de cadastro ou de sistema); e os volumes não registrados devidos a usos de água não-autorizados (ligações não-autorizadas e furtos de água em reservatórios, hidrantes, etc.).

Ao definirem perdas de água, Farley e Trow (2003) afirmam que as perdas de água ocorrem em todos os sistemas de distribuição, diferindo apenas pelo volume perdido, sendo que esse volume perdido depende das características da rede de distribuição e de outros fatores locais, bem como das práticas operacionais adotadas e do nível de tecnologia e conhecimento empregado no seu controle.

Thornton (2002, p.13 - tradução nossa) utiliza e acrescenta à definição de perdas em sistemas de distribuição de água, feita por Wallace (1987):

[...] Colocado de forma simplificada, os problemas de perda de água e de receita são [de ordem]

- Técnica: Nem toda a água distribuída pela companhia de distribuição de água chega ao seu cliente.

- Financeira: Nem toda a água que chega ao usuário final é medida adequadamente ou remunerada [à companhia distribuidora].

- [de] Terminologia: Existe uma carência de terminologia padronizada para perdas de água e de faturamento. 
Quando Thornton se refere a "problemas de terminologia", não significa que a terminologia em si afete de alguma forma as perdas. O que o autor tenta transmitir é a necessidade de uniformização de uma terminologia, uma vez que muitos dos termos utilizados em controle de perdas são interpretados de maneira diferente, em diferentes países, podendo causar interpretações equivocadas das ações para controle de perdas recomendadas e mesmo no que se refere ao cálculo de indicadores: para efeito de comparação entre sistemas e para o direcionamento adequado de ações, é fundamental que os termos utilizados sejam interpretados da mesma forma.

Muitas vezes se confundem os vazamentos ou falhas em equipamentos das instalações hidráulica dos consumidores com perdas de água. No entanto, é importante lembrar que, como esses vazamentos ocorrem no trecho de tubulação a jusante do hidrômetro, esse volume perdido é remunerado à companhia distribuidora de água, não acarretando em perdas. Na verdade esses volumes perdidos na instalação hidráulica dos consumidores se constituem em desperdícios e são alvo de procedimentos que visam o uso racional da água.

Apresentado o conceito de perdas, diferenciado de desperdício, é importante abordar a evolução na maneira como são quantificados os volumes perdidos.

No Brasil, por exemplo, eram contratados estudos de consultoria especializada para, através de levantamentos, medições e estimativas, se fazer a distribuição das perdas de água, calculando-se ou estimando-se as diferenças entre o volume entregue à distribuição e os volumes de usos autorizados, cobrados e não cobrados, chegando-se aos volumes das perdas. Esses estudos geravam gráficos conhecidos por "pizzas de perdas". Com base nos resultados desses estudos, é que eram, e ainda são priorizadas as ações para redução e controle das parcelas de perdas mais relevantes.

O primeiro estudo abrangente feito na RMSP, com o intuito de avaliação dos componentes dos volumes de usos e dos volumes perdidos, foi através de consultoria realizada pela empresa francesa Lyonnaise des Eaux Services Associés (LYSA), concluído no ano de 1993, para a Companhia de Saneamento Básico do Estado de São Paulo (Sabesp). 
Entre as dificuldades enfrentadas para a realização daqueles estudos estavam a falta de limites precisos entre setores de abastecimento, dificultando uma avaliação mais precisa, e a quantificação de volumes de usos sociais (volumes utilizados por habitações de população de baixa renda, geralmente em terrenos invadidos) (SABESP/LYSA, 1993).

Dos estudos realizados pela LYSA, resultou o perfil de perdas (ou "pizza de perdas") apresentado na Figura 2.1.

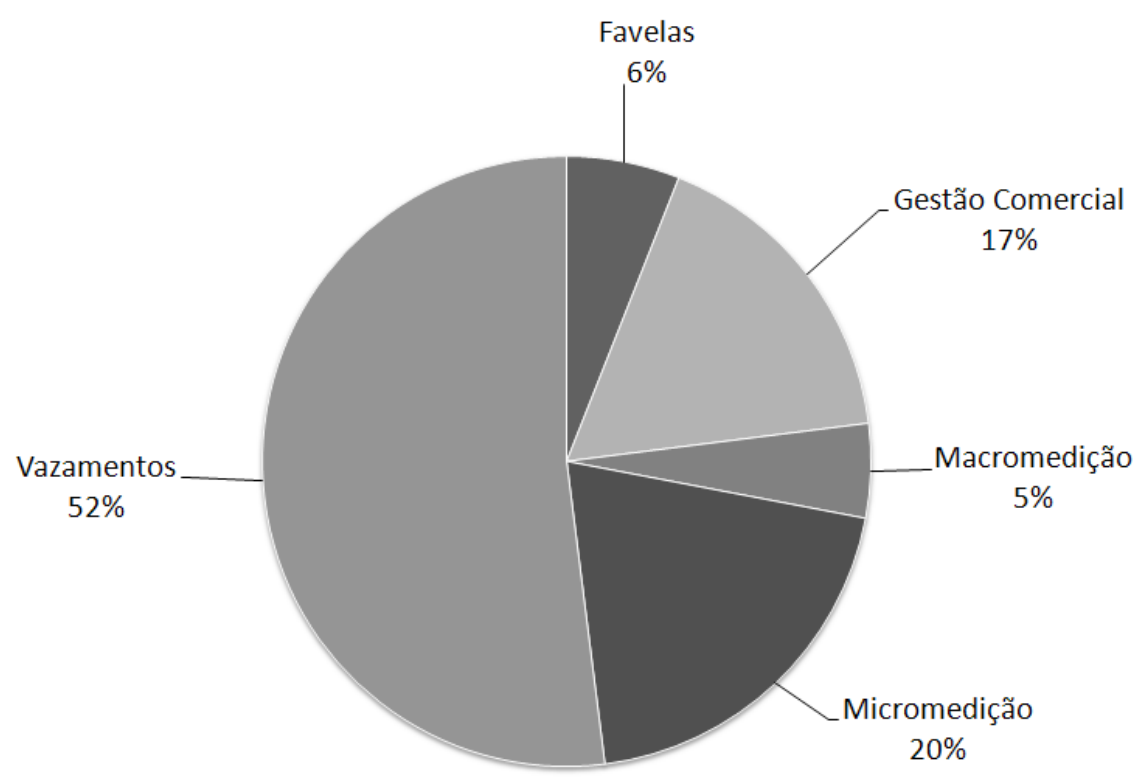

FONTE: SABESP/LYSA (1993)

FIGURA 2.1 - Perfil de Perdas da RMSP - 1993

Esses percentuais representam o peso de cada um dos componentes de perdas, em relação ao volume de água perdido e não ao volume distribuído ou produzido.

No final dos anos 90, a publicação do relatório "Water and Revenue Losses: Unaccounted-for-Water" - AWWA Research Foundation - (AWWARF, 1987), procurava, a partir de experiências bem sucedidas no Estado da Califórnia - USA, com procedimentos de auditoria da água, uniformizar definições para os termos relacionados a controle de perdas, numa tentativa de dirimir as confusões na interpretação dos termos "accounted-for water" e "unaccounted-for water" (que numa 
tradução livre seria algo como "água que se conhece a destinação", para o primeiro termo, e "água que se desconhece a destinação", para o segundo termo), que eram interpretados de maneiras diversas, além de propor os procedimentos para contabilização dos usos de água e das perdas, entre outros.

Em 1990, a American Water Works Association (AWWA) publicou a 1a edição do "Water Audits and Leak Detection - Manual of water supply practices - M36" que, a partir das conclusões dos estudos da AWWARF (1987), organiza, na forma de manual, os procedimentos e recomendações para a contabilização da água perdida em sistemas de abastecimento.

Ainda, então, havia um enfoque em detecção e reparo de vazamentos não-visíveis, como sendo a ação preponderante, senão a única, para redução e controle de perdas. Os termos utilizados eram "volume e controle de vazamentos", contrapondose aos termos "volume e controle de perdas", utilizados hoje.

Do referido Manual AWWA (1999, p. ix - tradução nossa) tem-se:

\begin{abstract}
A detecção e reparo de vazamentos em sistemas [de distribuição] de água é uma maneira efetiva de preservação de água e de economia de dinheiro. Programas de detecção de vazamentos preservam a água que as companhias de distribuição pagam para captar, tratar e pressurizar. Quando ocorrem vazamentos em um sistema [de distribuição] antes que a água chegue ao consumidor, as companhias de [distribuição] de água perdem faturamento e incorrem em custos desnecessários.
\end{abstract}

$\mathrm{Na}$ mesma época, foi sendo divulgada a iniciativa do Comitê de Operação e Manutenção, da International Water Association (IWA), para padronização de indicadores para sistemas de abastecimento de água, entre esses, os indicadores para controle de perdas. A idéia era, além de criar indicadores que pudessem servir para comparação entre diferentes sistemas, de diferentes países, a de criar um vocabulário padronizado, em que os termos propostos teriam o mesmo entendimento, facilitando as trocas de experiências. Até então, internacionalmente, muitos países ainda usavam o termo "unaccounted-for water" (água que não se conhece a destinação - tradução nossa), que foi substituído por "non-revenue water" (águas não-faturadas - tradução nossa), que melhor definia as perdas de água. Esse trabalho teve como base os estudos realizados pela Força Tarefa de Controle de Perdas (WLTF) da IWA, cujos resultados foram sendo divulgados em artigos na 
publicação AQUA/IWA (LAMBERT et al.,1999) e, na sua versão final, no documento "Losses from water supply systems: Standard terminology and recommended performance measures" - IWA / Blue Pages (2000).

Esse documento, além de ter proposto definições padronizadas para os termos utilizados em controle de perdas, utilizadas hoje pela grande maioria das áreas de controle de perdas de empresas de distribuição de água no mundo todo, apresentou uma forma, hoje consagrada, de representação dos volumes de usos e perdas, num formato de matriz, conhecida por Balanço Hídrico.

Quanto aos propósitos desse documento, IWA / Blue Pages (2000 - tradução nossa) afirma:

A quantidade de água perdida é um indicador importante da evolução positiva ou negativa da eficiência da distribuição de água, tanto individualmente para um ano [específico], como para [mostrar] a tendência ao longo de um período de anos. Altos e crescentes volumes de perda anual de água, que são um indicativo de planejamento e execução ineficientes e de pouca atividade de manutenção, deveriam ser o gatilho para se iniciar um programa de controle ativo de vazamentos.

Contudo, uma rede de distribuição livre de vazamentos não é um objetivo técnica e economicamente realizável e um baixo nível de perdas de água não pode ser evitado, mesmo nos sistemas mais bem operados [e] com manutenção eficiente, onde os operadores dão bastante atenção às atividades de controle de perdas.

Com a crescente tendência internacional em busca da sustentabilidade, eficiência econômica e proteção ao meio ambiente, o problema de perdas em sistemas de abastecimento de água é de grande interesse em todo o mundo. Ambos os aspectos técnico e financeiro estão recebendo atenção crescente, especialmente durante os períodos de estiagem e de rápido desenvolvimento.

[...] Em 1996, o Comitê de Operação e Manutenção da Divisão de Distribuição da IWA formou uma Força Tarefa para analisar as metodologias existentes para comparações internacionais de perdas de água em sistemas de abastecimento. Os objetivos principais eram:

- preparar uma metodologia padrão básica recomendada para o cálculo das perdas reais e aparentes

- analisar e recomendar indicadores de performance selecionados para comparações internacionais de perdas 
Na Figura 2.2, a seguir, é apresentado o balanço hídrico proposto pela WLTF/IWA.

\begin{tabular}{|c|c|c|c|c|}
\hline \multirow{7}{*}{$\begin{array}{c}\text { Volume de } \\
\text { Água que } \\
\text { Entra no } \\
\text { Sistema }\end{array}$} & \multirow{2}{*}{$\begin{array}{l}\text { Consumo } \\
\text { Autorizado }\end{array}$} & $\begin{array}{l}\text { Consumo } \\
\text { Autorizado } \\
\text { Cobrado }\end{array}$ & $\begin{array}{c}\text { Consumo Medido } \\
\text { Cobrado }\end{array}$ & $\begin{array}{c}\text { Água } \\
\text { Faturada }\end{array}$ \\
\hline & & $\begin{array}{c}\text { Consumo } \\
\text { Autorizado } \\
\text { Não-Cobrado }\end{array}$ & $\begin{array}{c}\text { Consumo Medido } \\
\text { Não-Cobrado }\end{array}$ & \multirow{6}{*}{$\begin{array}{c}\text { Água } \\
\text { Não-Faturada }\end{array}$} \\
\hline & \multirow{5}{*}{$\begin{array}{l}\text { Perdas de } \\
\text { Água }\end{array}$} & \multirow{2}{*}{$\begin{array}{l}\text { Perdas } \\
\text { Aparentes }\end{array}$} & $\begin{array}{c}\text { Consumo } \\
\text { Não-Autorizado }\end{array}$ & \\
\hline & & & $\begin{array}{l}\text { Imprecisões dos } \\
\text { Medidores }\end{array}$ & \\
\hline & & \multirow{3}{*}{ Perdas Reais } & $\begin{array}{c}\text { Vazamentos em } \\
\text { Adutoras e Rede de } \\
\text { Distribuição }\end{array}$ & \\
\hline & & & $\begin{array}{l}\text { Vazamentos e } \\
\text { Extravasamentos em } \\
\text { Reservatórios }\end{array}$ & \\
\hline & & & $\begin{array}{l}\text { Vazamentos em } \\
\text { Ligações Prediais }\end{array}$ & \\
\hline
\end{tabular}

FONTE: IWA/BLUE PAGES (2000) - tradução nossa.

FIGURA 2.2 - Balanço Hídrico das 'Melhores Práticas' - IWA

A partir da divulgação desses trabalhos da WLTF, foram amplamente difundidas a abordagem e as definições conceituais propostas, sendo as perdas de água totais, num sistema de abastecimento, ou num sistema de distribuição de água, divididas entre perdas reais e perdas aparentes.

Quanto a essas "novas" definições, Farley e Trow (2003) relembram que a expressão "perdas reais" foi criada para substituir a expressão "perdas físicas" e a expressão "perdas aparentes" para substituir "perdas não-físicas". 
Thornton (2002, p. 13 - tradução nossa), trata o assunto da seguinte forma:

[...] A International Water Association (IWA) define duas categorias principais, sob as quais se classificam todos os tipos de perdas de água em sistemas de abastecimento:

- Perdas reais são as perdas físicas de água de um sistema de distribuição e incluem os vazamentos e extravasamentos, antes do ponto final de uso.

- Perdas aparentes são essencialmente perdas 'no papel' e se consistem em usos de consumidores que não são registrados devidos a erros de medição, avaliações incorretas dos usos não-medidos, ou consumos não-autorizados.

Enquanto essas duas definições se distinguem por uma diferença física notória, uma diferença econômica dramática também existe, numa base de custo marginal. As perdas reais, que no caso mais comum são vazamentos, são valoradas, tipicamente, a um custo marginal de produção de água. As perdas aparentes, que ocorrem no [âmbito do] consumidor final, penalizam a empresa distribuidora de água ao preço de venda - uma taxa usualmente muito mais alta do que o custo de produção. Enquanto os custos marginais são apenas custo de longo prazo, e outros custos de longo prazo também precisam ser avaliados, os custos envolvidos nas perdas reais e aparentes requerem que seja realizada uma avaliação cuidadosa de cada uma [perdas reais e perdas aparentes], para se planejar o programa de controle de perdas mais adequado.

A abordagem de se contabilizarem os volumes de usos e perdas da água entregue para distribuição, através da elaboração do Balanço Hídrico, é chamada pela WLTF de "Top Down" (THORNTON, 2002) (de cima para baixo, em Português). Esse nome se deve ao procedimento de se partir do volume total entregue para distribuição (corrigidos possíveis erros na totalização desse volume, a partir de testes de calibração de medidores), sendo descontados todos os usos conhecidos, chegandose aos volumes perdidos.

A distribuição das perdas, entre reais e aparentes, neste caso, é dada por estimativas que se têm a partir de testes realizados na área em estudo ou, a partir de percentuais de perdas aparentes levantados, como percentual médio de submedição em hidrômetros, percentual médio de fraudes, estimado para a região, e percentual médio de falhas na cobrança, obtido através de levantamentos.

Reportando à Figura 2.1, apresentada na página 31, a partir da abordagem proposta no Balanço Hídrico, os componentes da chamada "pizza de perdas", atualizada, ficam como apresentado na Figura 2.3, com as observações de que os erros de macromedição não são mais classificados como perdas de água, sendo, como já mencionado, utilizados para correção dos volumes totais entregues para distribuição 
de água, antes de se descontarem os usos autorizados, para cálculo do volume total de perdas.

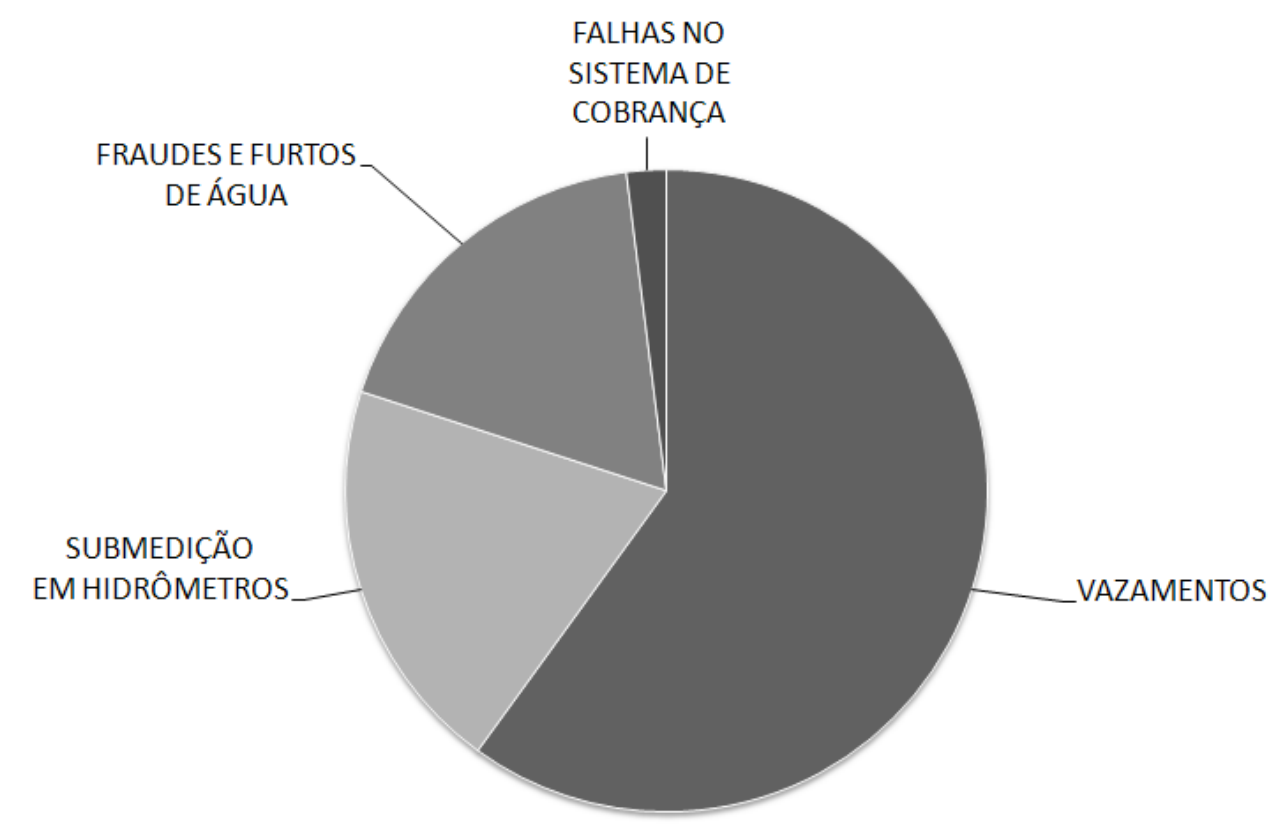

FIGURA 2.3 - Perfil de Perdas - Abordagem Atual

Quanto à parcela de perdas, atribuída a "Favelas", apesar desse volume consumido representar uma perda de faturamento, para as companhias de distribuição de água, esse volume não é classificado como perda, mas como volume de usos sociais e, portanto, de consumo autorizado não-cobrado. Nessa parcela, de consumos autorizados não-cobrados, também são incluídos os volumes de usos próprios e operacionais, além dos volumes de usos em treinamento e combate a incêndios. No entanto, em sistemas de distribuição de água do porte dos da RMSP, quando comparados ao volume total anual fornecido à distribuição, essas parcelas possuem um peso ínfimo, sendo considerada, usualmente, somente, a parcela de usos sociais.

Dessa forma, quando se consideram todos os componentes que contribuem para as perdas de faturamento, o perfil a ser considerado deve ser o representado no gráfico apresentado na Figura 2.4. 


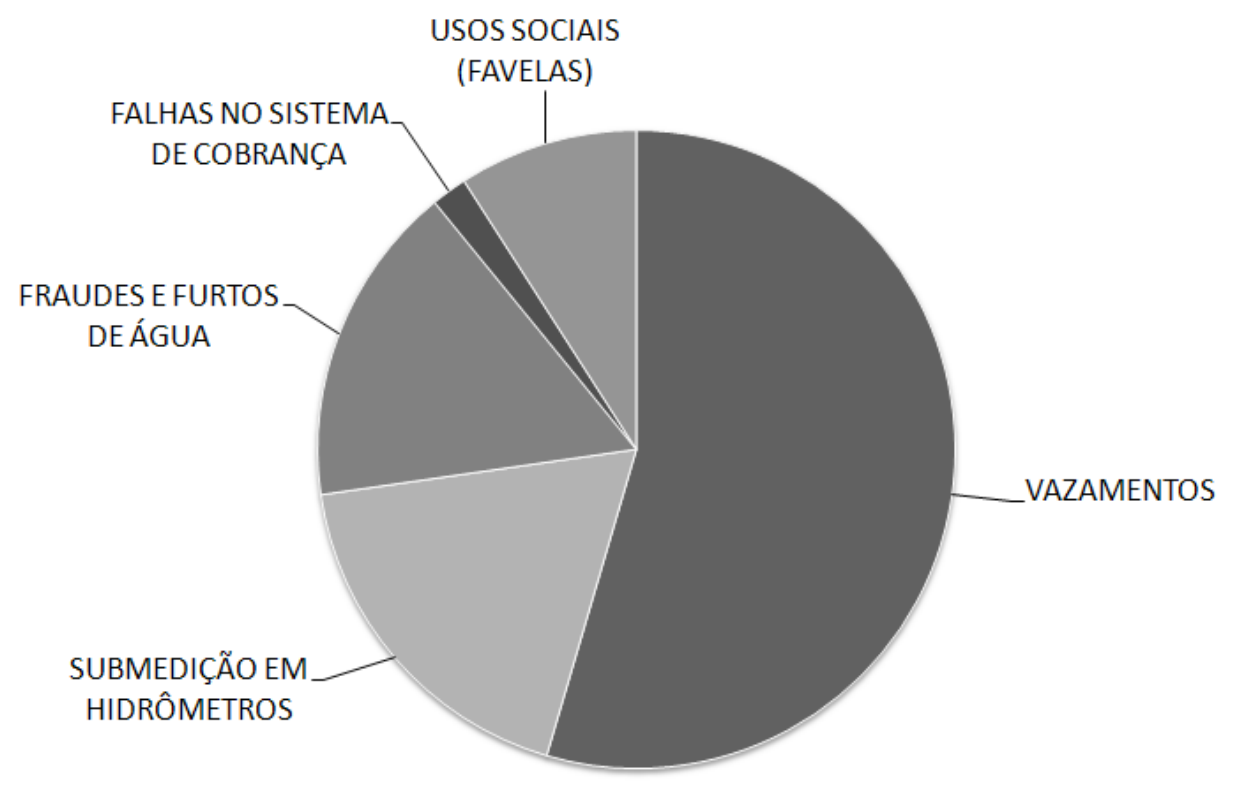

FIGURA 2.4 - Perfil das Perdas de Faturamento

A outra abordagem, também proposta pela WLTF, é chamada de "Bottom Up" (THORNTON, 2002) (de baixo para cima, em Português), onde se partem de medições de vazão de vazamento, através de resultados de testes de vazão mínima noturna, por exemplo, assumindo-se o volume de vazamentos calculado, descontados os usos legítimos estimados, como sendo o volume de perdas reais. Definido esse volume de perdas reais, são descontados os usos autorizados conhecidos, para se chegar aos volumes de perdas aparentes.

Definidas as perdas reais e aparentes, assim como as formas que essas perdas ocorrem, é importante que se explicitem as causas dessas perdas.

Discorrendo sobre as causas das perdas reais, Thornton (2002) afirma que a forma mais comum desse tipo de perdas é o vazamento e que entre as causas para ocorrência de vazamentos estão: a baixa qualidade da infra-estrutura, da mão-deobra e de materiais; a manipulação/estocagem inadequada de materiais; um processo de reaterro de valas inadequado; as ondas de pressão ou transientes hidráulicos; a variação de pressão no sistema de distribuição, entre outras. 
Tardelli Filho (2004, p. 504) ilustra com clareza as ações para se combaterem essas causas, na Figura 2.5, modificada por Thornton (2006 - informação verbal) ${ }^{1}$, onde é apresentada a classificação que se convencionou atribuir aos três tipos de vazamentos: a) vazamentos inerentes, que são vazamentos não-detectáveis por equipamentos de detecção acústica e ocorrem nas juntas e conexões das tubulações, tendo como características principais uma vazão muito baixa, mas uma duração de vazamento muito longa; b) os vazamentos não-visíveis, que são passíveis de detecção por métodos acústicos e, dependendo do ponto da tubulação em que ocorrem, do tipo de solo onde está assentada a tubulação, da sua profundidade e do tipo de pavimento, pode demorar anos até aflorarem à superfície; e c) vazamentos visíveis, que são os vazamentos que afloraram à superfície e são detectáveis a olho nu.

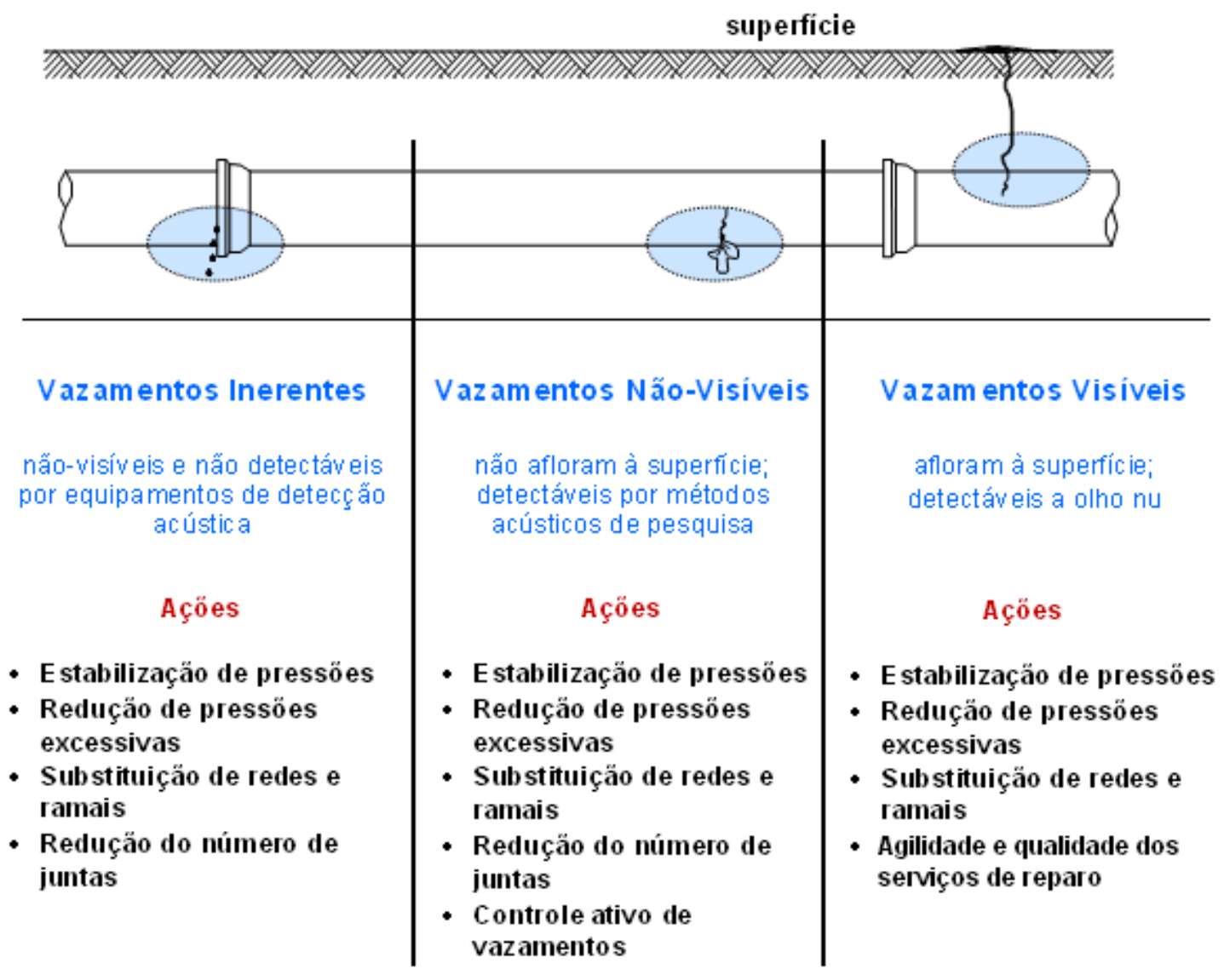

FONTE: TARDELLI FILHO (2004) - modificado por THORNTON (2006) - adaptaçẩo nossa.

FIGURA 2.5 - Síntese das ações para o controle e redução de perdas reais

\footnotetext{
${ }^{1}$ Informação fornecida por Julian Thornton, em Painel sobre Eficiência Operacional, no XVII Encontro Técnico da Associação dos Engenheiros da Sabesp (AESABESP). São Paulo, 2006.
} 
Estão relacionadas, ainda nessa figura, as principais ações para a prevenção e controle de cada um desses tipos de vazamento. Como ações preventivas da ocorrência dos três tipos de vazamento, são recomendadas a estabilização e redução de pressão e a substituição de redes e ramais, sendo esta última também corretiva. A redução do número de juntas é recomendada como ação preventiva à ocorrência de vazamentos inerentes e de vazamentos não-visíveis. A ação corretiva para os vazamentos não-visíveis é o chamado controle ativo de vazamentos que, além de envolver os serviços de detecção acústica de vazamentos, engloba, na sua forma mais completa, o monitoramento da vazão dos vazamentos, através de testes de vazão mínima noturna, medida em áreas de rede de tamanho reduzido, como, por exemplo, nas chamadas "Waste Meter Areas (WMAs)" (áreas para medição de desperdício, numa tradução livre), como o modelo adotado nas cidades do Japão (Waterworks \& Sewerage Bureau of Nagoya City, 2002 - informação verbal) ${ }^{1}$ e em outras localidades, como no Reino Unido (BUTLER, 2000) ou as de tamanho um pouco maior chamadas de "District Metered Areas (DMAs)" (distritos de medição, numa tradução livre), utilizadas no Reino Unido, (WRc, 1994; BUTLER, 2000; MORRISON, 2004) e de Distritos Pitométricos, que são o equivalente às DMAs, no Brasil. Já, para os vazamentos visíveis, a ação corretiva é o reparo de vazamento e a recomendação é para a redução do tempo de reparo.

Frente às principais causas de ocorrência das perdas reais, a Força Tarefa para Controle de Perdas da IWA propôs um diagrama que ilustra os quatro grupos básicos de ações para gerenciamento das perdas reais, reproduzido na Figura 2.6, a partir de ilustração de Thornton (2002, p. 48).

1 Informação fornecida durante curso de especialização em controle de perdas de água na distribuição, "Non-revenue water management II", ministrado pelo Waterworks \& Sewerage Bureau of Nagoya City. Japão, 2002. 


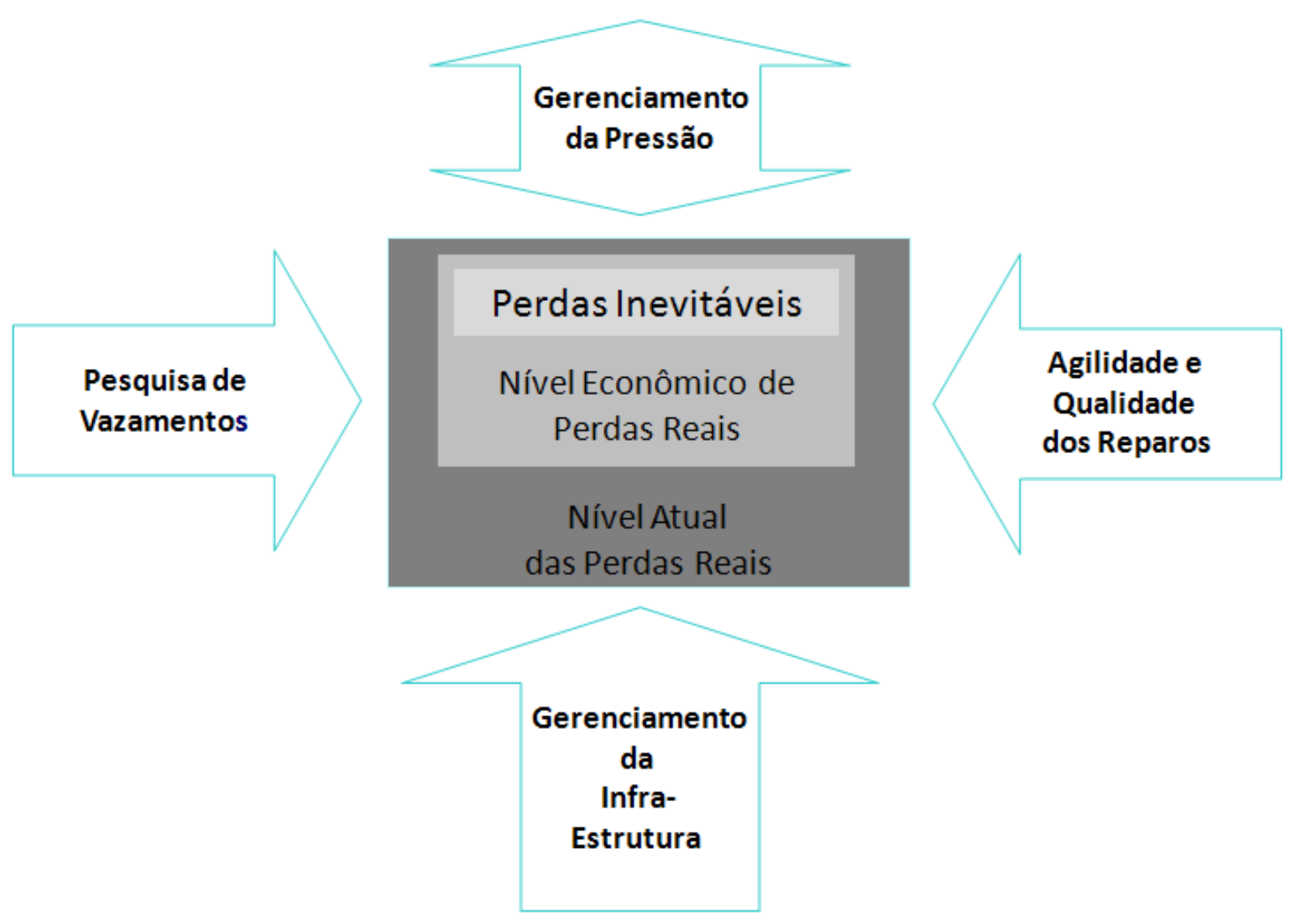

FONTE: THORNTON (2002) - adaptação e tradução nossa.

FIGURA 2.6 - Os quatro componentes de uma política de gerenciamento de perdas reais, bem sucedida

O diagrama da Figura 2.6, representação confeccionada no âmbito da WLTF - IWA, sintetiza uma série de conceitos, desenvolvidos durante anos por aquele grupo.

O retângulo maior, que engloba os outros dois, representa o nível anual de perdas reais atual, num determinado sistema de distribuição. À medida que ocorrem novos vazamentos, a cada ano, esse volume de perdas tende a aumentar, gradualmente, a menos que todos os quatro componentes básicos para gerenciamento de perdas reais, representados pelas quatro setas, sejam efetivamente aplicados (LAMBERT; McKENZIE, 2002); o segundo retângulo representa o nível de perdas que seria possível de ser atingido, se fossem investidos recursos tais, que igualariam o retorno financeiro esperado pelo custo do volume de água perdido recuperado (conceito de nível econômico de perdas reais); finalmente, o retângulo menor, englobado pelos outros dois retângulos, representa o nível mínimo de perdas, tecnicamente possível de ser atingível, se não houvesse limitações de recursos financeiros para investir no controle de perdas, mesmo sendo antieconômica a busca desse nível. 
As setas apontadas para cada uma das faces do retângulo maior representam as ações, convencionadas como melhores práticas de operação, pela WLTF, para gerenciamento das perdas reais em um sistema de distribuição de água.

Segundo Lambert (2006 - informação verbal) ${ }^{1}$ o significado desse diagrama é: para se reduzir o nível das perdas reais, devem ser aplicados todos os grupos de ações, simultaneamente, representados pelas setas, no sentido de se comprimir o retângulo maior (em Inglês, "squeezing the box"), sendo os limites de compressão do retângulo externo representados pelos dois retângulos internos, cada um, por sua vez, representando uma política de controle de perdas e uma disponibilidade de orçamento para sua redução e controle.

Outra analogia que se pode depreender do diagrama é que, axialmente, uma ação se contrapõe à outra, para que o retângulo maior (o nível atual de perdas reais) seja reduzido. Nesse sentido, analisando-se, primeiramente, o eixo horizontal, a pesquisa de vazamentos não-visíveis, para ser eficaz na redução das perdas reais, precisa estar associada à agilidade e qualidade nos reparos dos vazamentos localizados. Da mesma forma, no eixo vertical, um gerenciamento de pressões eficaz necessita de um gerenciamento da infra-estrutura de distribuição adequado: uma boa qualidade dos materiais e peças empregados, associada à execução dos serviços com mãode-obra de qualidade e serviços de manutenção e de renovação da infra-estrutura adequados.

De maneira análoga às perdas reais, Thornton (2002) afirma que as perdas aparentes podem ocorrer de três formas básicas: erros na medição do volume de água consumido; erros na contabilização desses volumes; e usos não-autorizados.

As ações para controle das perdas aparentes são, basicamente: inspeções em ligações inativas; inspeções caça-fraudes; acompanhamento de variações bruscas de consumo; e substituição preventiva e corretiva de hidrômetros.

Quanto ao diagrama relacionando as ações para controle de perdas aparentes, apesar de Thornton (2002) ter proposto uma forma de representação e de Tardelli (2004) propor uma adequação àquela representação, ainda não há consenso quanto a uma forma padrão para esse diagrama.

\footnotetext{
${ }^{1}$ Informação fornecida por Allan Lambert durante Seminário Internacional de Eficiência Operacional em Sistemas de Água. São Paulo: Sabesp, 2006.
} 
Cabe ressaltar que, tanto para as perdas reais, quanto para as perdas aparentes, 0 nível econômico de perdas é apenas teórico e o seu cálculo permanece um desafio para os estudiosos. Já foram propostas algumas abordagens, para o cálculo do nível econômico de perdas reais, não se conhecendo qualquer aplicação prática, bem sucedida, até o momento.

Finalmente, com base na literatura especializada e na experiência profissional deste autor, pode-se afirmar que as ações para controle de perdas nada mais são do que a aplicação das chamadas boas práticas operacionais e de gestão ou, em Inglês, "best practice in management of water losses" (IWA / BLUE PAGES, 2000).

A IWA / Blue Pages (2000) afirma que "as melhores práticas na gestão das perdas de água se consistem na combinação do cálculo contínuo do balanço hídrico em conjunto com medições de vazão mínima noturna numa base contínua ou conforme necessária." (tradução nossa)

Essa combinação referida pela IWA se consiste na aplicação de ambas as abordagens propostas pela WLTF: "Top-Down" e "Bottom-Up".

Nesse enfoque, de que as ações para controle de perdas nada mais são que a implementação de boas práticas operacionais e de gestão, as ações para redução de perdas reais, propostas na Figura 2.6, "os quatro componentes de uma política de gerenciamento de perdas reais bem sucedida", nada mais são do que boas práticas de gestão e operacionais.

Nesse aspecto, vale ressaltar que os "bureaus" de distribuição de água no Japão, em especial o Waterworks and Sewerage Bureau of Nagoya City, apesar de não seguirem preceitos estabelecidos pela IWA, vêm, ao longo de, pelo menos, 50 anos, se aprimorando nessas boas práticas operacionais.

No caso do Japão, essas práticas podem ser traduzidas na elaboração de normas e procedimentos, no treinamento, qualificação e certificação de mão-de-obra, própria e contratada, e na fiscalização sistemática da execução dos serviços e da qualidade dos equipamentos, peças, materiais e ferramentas empregadas. Tudo isso, de uma forma dinâmica, que pressupõe o constante aprimoramento de normas, procedimentos, peças, materiais, ferramentas e equipamentos. 
Paralelamente, são implementadas, regularmente, ações de controle ativo de vazamentos (medição de vazão de vazamentos, como testes de vazão mínima noturna), além de ações para prevenção de vazamentos: substituição de rede antiga e com histórico de vazamentos e aperfeiçoamento das ligações de água (peças, materiais e procedimentos).

Essas ações resultam numa infra-estrutura de distribuição com alta confiabilidade contra a ocorrência de vazamentos e arrebentados (Waterworks and Sewerage Bureau of Nagoya City, 2002 - informação verbal) ${ }^{1}$.

Quanto ao gerenciamento de pressões na rede de distribuição, na Cidade de Nagoya todos os setores são abastecidos por reservatório próprio, chamados de estações de distribuição de água ("water distribution plants", em Inglês) não fazendo uso de válvulas redutoras de pressão. Quanto a sistemas de bombeamento, o sistema de abastecimento utiliza apenas duas estações elevatórias.

Essas características no gerenciamento de pressões se devem, além da topografia favorável (sem grande variação de relevo) onde está localizada a Cidade de Nagoya, à setorização adequada da rede de distribuição e ao refinamento dessa setorização, através da divisão dos setores em blocos menores (nos cerca de $8.000 \mathrm{~km}$ de rede de distribuição foram construídos mais de 3.000 blocos, que dividem os setores em trechos de rede com pouco mais de $2 \mathrm{~km}$ cada), o que proporciona uma equalização de pressões muito mais adequada, além de melhora na qualidade do abastecimento e nas condições para manutenção. (Waterworks and Sewerage Bureau of Nagoya City, 2002 - informação verbal) ${ }^{2}$.

Cabe ressaltar que, a partir do final da década de 90, até os dias de hoje, a IWA tomou para si a liderança mundial nas ações de combate às perdas, através da Força Tarefa para Controle de Perdas (WLTF), sendo que quase a totalidade dos países que desenvolvem ações sistemáticas para o controle de perdas seguem os preceitos recomendados pela WLTF/IWA (os países da União Européia, muitos países da Ásia, alguns países da África, a Austrália, América do Norte, Brasil, etc.). O Japão foi citado por desenvolver ações de controle de perdas desde o final da

\footnotetext{
1 Informação fornecida durante curso de especialização em controle de perdas de água na distribuição, "Non-revenue water management II", ministrado pelo Waterworks \& Sewerage Bureau of Nagoya City. Japão, 2002.

2 o mesmo que 1.
} 
década de 40, e ter atingido níveis de excelência nessa área do conhecimento, tendo aplicado muitas das ações propostas pela WLTF/IWA com vários anos de antecedência. Por essa razão, as referências bibliográficas nesse campo do conhecimento se concentram em autores ligados à IWA, além de algumas referências ligadas ao Japão.

\subsubsection{Uso Racional da Água}

Silva (2004, p.561) apresenta a conservação dos recursos hídricos numa abordagem de gestão da demanda, através do uso racional da água, quando afirma que:

[...] Nas últimas décadas, verificou-se crescimento vertiginoso das cidades, em decorrência do êxodo da população rural, e de formação de grandes áreas concentradas, tornando cada vez mais escasso o recurso natural água, pois além do aumento populacional, outros fatores contribuem para a escassez, como a poluição dos recursos hídricos implicando em diminuição da disponibilidade de água com qualidade para os diversos tipos de usos, e também o conceito convencional de que o incremento na melhoria do bemestar está diretamente relacionado com o aumento do consumo individual de água.

A escassez de recursos hídricos, na quantidade e qualidade demandada para os diversos usos que as populações das cidades fazem desses recursos, vem motivando novos tipos de ações, alternativas à busca de novos mananciais, agora raros e custosos, como ações para gestão da demanda por água, onde se inserem os programas para difusão do uso racional da água.

Em uma tabela onde compara a situação hídrica de países europeus e de estados brasileiros, Barth (2002, p. 592) apresenta uma classificação que afirma ser acima de $2.500 \mathrm{~m}^{3} /$ habitante/ano a disponibilidade hídrica considerada adequada para 0 abastecimento humano; disponibilidades hídricas inferiores a $2.500 \mathrm{~m}$ 3/habitante/ano são consideradas pobres; e, abaixo de $1.500 \mathrm{~m}$ /habitante/ano encontram-se regiões consideradas em situação crítica de abastecimento.

A Região Metropolitana de São Paulo (RMSP), localizada na Bacia do Alto Tietê, tem uma disponibilidade hídrica de cerca de $200 \mathrm{~m}$ 3/habitante/ano (THAME, 2000, p. 12), que, tomando por base a classificação apresentada por Barth, enquadraria a 
RMSP entre as regiões mais críticas para o abastecimento humano, próxima ao nível de regiões desérticas como Líbia ( $160 \mathrm{~m}^{3} / \mathrm{habitante/ano),} \mathrm{Arábia} \mathrm{Saudita}$ (160 m³/habitante/ano) e Emirados Árabes (190 m³/habitante/ano), (REBOUÇAS, 2002, p. 20).

Os programas de uso racional da água, como estruturados no Brasil, se baseiam em estudos e programas desenvolvidos em países como os Estados Unidos da América (Environmental Protection Agency - EPA), e têm por base ações de cunho tecnológico: incentivo ao desenvolvimento de novas tecnologias e equipamentos economizadores de água e benchmarking em programas, equipamentos e tecnologias desenvolvidos em outros países; de cunho educacional/cultural: cursos e palestras para conscientização e difusão dos conceitos e hábitos do uso racional da água; de cunho normativo e legal: participação na elaboração de Normas Técnicas e fornecimento de dados para elaboração da Legislação Estadual (SABESP - MPC, 2006).

Segundo a Sabesp - MPC (2006), no Estado de São Paulo, o Decreto 45.805, de 15 de maio de 2001, instituiu, no âmbito dos órgãos da administração pública, o Programa Estadual de Uso Racional da Água Potável, além do Conselho de Orientação do Programa Estadual de Água Potável (CORA), criando, ainda, em cada Secretaria de Estado e Autarquia de Governo, uma Comissão Interna de Uso Racional de Água Potável (CIRA), para avaliação do consumo de água e proposição de medidas de uso racional da água.

O Decreto 48.138 , de 8 de outubro de 2003, institui uma série de medidas para evitar o desperdício de água tratada em órgãos do Governo, determinando que a fiscalização dessas medidas seja feita pela Secretaria de Energia, Recursos Hídricos e Saneamento (atualmente na Coordenadoria dos Recursos Hídricos, sob a Secretaria Estadual do Meio Ambiente).

Como resultado desse tipo de ação, pode-se citar o Programa de Uso Racional da Água (PURA), desenvolvido pela Sabesp, em conjunto com a Escola Politécnica da Universidade de São Paulo, que, após a implantação das medidas recomendadas por esse programa no Hospital das Clínicas, na Cidade Universitária da Universidade de São Paulo e no Entreposto Ceagesp, obteve reduções no consumo de água da ordem de $25 \%$, 27\% e 32\%, respectivamente. (SABESP - MPC, 2006) 
Focando nas ações, entre as práticas de engenharia, conforme classifica a USEPA (2007) para medidas de uso racional da água, destacam-se: a) instalações hidráulicas, nos imóveis dos consumidores, com dispositivos economizadores de água; b) caixas de descarga com um volume máximo de $6 \mathrm{~L}$ por descarga; c) chuveiros de baixa vazão; d) aeradores para torneiras; e e) reúso de água utilizada na cozinha, banheiras, chuveiros e máquinas de lavar, na lavagem de pisos, em regas de jardins e mesmo reutilização em descargas de vasos sanitários.

Já, a aplicação de práticas comportamentais, envolve, segundo a USEPA (2007), a mudança dos hábitos de consumo, de maneira que a água seja utilizada com maior eficiência, reduzindo o consumo global em uma residência.

É importante que se destaque, ainda, entre as ações preconizadas para o uso racional da água, a instalação de VRPs na rede de distribuição de água que, nos casos de imóveis com abastecimento direto e mesmo em imóveis com abastecimento indireto (uso de caixa d'água), nos pontos em que o abastecimento é direto (torneiras de tanques para lavagem de roupa, torneiras de jardins e algumas torneiras em cozinhas), funcionaria como um redutor da vazão desses equipamentos sujeitos ao abastecimento direto da rede de distribuição, uma vez que essa vazão é função da pressão na rede (THORNTON, 2002; FARLEY \& TROW, 2003; THORNTON \& LAMBERT, 2005; WRAS, 2005; VAN DER KLEIJ, 2007).

Quanto à generalização da utilização de caixas d'água pelos consumidores, na RMSP, em estudo recente publicado pelo Instituto de Pesquisas Tecnológicas do Estado de São Paulo (IPT), encomendado pela Sabesp, para avaliação da submedição média em hidrômetros instalados em ligações localizadas na Zona Oeste da RMSP, foi constatado que, de uma amostra de cerca de trezentas e cinqüenta ligações de água em economias residenciais unifamiliares, 100\% tinham caixas d'água instaladas e, na faixa de consumo acima de 20 m³/mês, 100\% tinham duas ou mais caixas d'água instaladas (IPT, 2007).

Convém relembrar que, a avaliação da influência da redução de pressão, provocada pela instalação de VRPs, sobre o nível de consumo médio das ligações afetadas por essa redução, em ligações localizadas na RMSP, é, justamente, o objeto do presente trabalho. 


\subsubsection{Reúso da Água}

Apesar de não estar diretamente ligado ao tema central do presente trabalho, o chamado "Reúso da Água" se consiste numa das ferramentas para o gerenciamento dos recursos hídricos, sendo, por esse motivo, breve e resumidamente descrito neste item.

Lavrador Filho (1987, p.4) afirma que "o reuso da água pode ocorrer de forma direta ou indireta, através de ações planejadas ou não e para atender às demandas do uso original ou de outros usos da água."

Após considerações sobre as várias formas de se conceituar, à época, o reúso da água, Lavrador Filho $(1987$, p.9) propõe a adoção, dentre outras, das definições relacionadas na seqüência, diferenciando reúso, num sentido mais geral, de reciclagem da água, num sentido mais restrito:

Reuso da água: É o aproveitamento de águas previamente utilizadas, uma ou mais vezes, em alguma atividade humana, para suprir as necessidades de outros usos benéficos, inclusive o original. [...]

Reciclagem da água: É o reuso interno da água, antes de sua descarga em um sistema geral de tratamento ou outro local de disposição, para servir como fonte suplementar de abastecimento do uso original. É um caso particular do reuso direto.

No Brasil, o reúso da água não tem, ainda, sido empregado em grande escala. No entanto, no Reino Unido o reúso de água de chuva, através da instalação de cisternas, é altamente incentivado (UK ENVIRONMENT AGENCY, 2007) ${ }^{1}$ e no Japão, cidades como Tóquio, Fukuoka e Nagoya utilizam redes de água reciclada, geralmente proveniente de tratamento avançado de efluentes, para uso em larga escala, principalmente em descargas de toaletes públicos (SUZUKI, 2002; TOKYO BUREAU OF WATERWORKS, 2002 - informação verbal) $)^{2}$. A Cidade de Nagoya, por exemplo, utiliza água proveniente de processo de tratamento avançado de esgotos, da Estação de Tratamento de Esgotos (ETE) de Horidome, na descarga de toaletes públicos e em lagos e irrigação no Parque Wakamiya-Odori e no Jardim de

\footnotetext{
${ }^{1}$ UK Environment Agency. Water resources: Rainwater reuse. Disponível em <http://www.environment-agency.gov.uk/subjects/waterres/286587/286911/548861/861599/ ?lang=_e $>$. Acesso em abril de 2007.

2 Informação fornecida durante curso de especialização em controle de perdas de água na distribuição, "Non-revenue water management II", ministrado pelo Waterworks \& Sewerage Bureau of Nagoya City. Japão, 2002.
} 
Orquídeas, uma das principais atrações turísticas da Cidade. (SAMPA, 2002; WATERWORKS \& SEWERAGE BUREAU OF NAGOYA CITY, 2002 - informação verbal) ${ }^{1}$.

\subsection{GERENCIAMENTO DE PRESSÕES}

Neste item, são apresentados conceitos e ações, um pouco mais detalhados que no item 2.1, além de citar estudos e experiências profissionais relacionadas ao tema. São abordadas, ainda, informações a respeito do efeito da redução de pressão no consumo de água

\subsubsection{Conceituação}

O Gerenciamento adequado de pressões, em sistemas de distribuição de água, é considerado uma das ações fundamentais para a otimização da operação desse tipo de sistema e, para muitos especialistas, a ação que proporciona melhores e mais rápidos retornos, aos investimentos aplicados na redução de perdas reais.

Segundo Thornton et al. (2005), o gerenciamento de pressões pode ser definido como a prática de gerenciar pressões nos sistemas de distribuição de água, nos seus níveis ótimos, assegurando suficiente e eficiente abastecimento para 0 atendimento adequado dos usos dos consumidores, ao mesmo tempo em que se reduzem as pressões desnecessárias, ou excessivas, eliminando surtos de pressão e falhas de controle, que provocam aumento de vazamentos. Thornton ressalta que, em muitos casos, o gerenciamento de pressões se revela uma solução, não somente para a redução do volume de perdas reais, mas também, para as causas desse tipo de perdas, o que o torna a mais eficiente ferramenta no controle sustentável das perdas reais (vazamentos).

De uma maneira ampla, o gerenciamento de pressões envolve a adequada setorização da rede de distribuição, a delimitação de zonas de pressão, o controle

\footnotetext{
${ }^{1}$ Informação fornecida durante curso de especialização em controle de perdas de água na distribuição, "Non-revenue water management II", ministrado pelo Waterworks \& Sewerage Bureau of Nagoya City. Japão, 2002.
} 
adequado de bombeamentos, a redução de pressões excessivas, que ocorrem em trechos da rede, e a manutenção de um nível mínimo de pressão para o adequado abastecimento dos consumidores.

Entretanto, quando o enfoque da ação é a redução e controle de perdas, tem sido adotada, em muitos sistemas de distribuição de água, somente a vertente de redução de pressão, traduzida na instalação de válvulas redutoras de pressão (VRPs), cuja aplicação é discutida no item 2.2.2.

Sobre esse tópico, Farley e Trow (2003, p.160 - tradução nossa) consideram:

\begin{abstract}
Gerenciamento de pressões não é apenas instalar VRPs em conjunto com trabalhos de medição de vazão. É importante que se considere o sistema de abastecimento e de distribuição de água como um todo, da captação ao consumidor. As pressões deveriam ser otimizadas numa estratégia integrada de longo prazo e a pressão deveria ser um fator constantemente considerado em muitos aspectos da operação, manutenção e reabilitação e da extensão da rede de distribuição.
\end{abstract}

Butler (2000, p.82), afirma ser o gerenciamento de pressões um elemento de destaque numa estratégia para controle de vazamentos e que a redução de pressão, provavelmente, seja a maneira mais simples e mais imediata para a redução das perdas por vazamento.

No entanto, como Farley e Trow, chama a atenção para o fato do gerenciamento de pressões poder ser efetuado através de várias maneiras e não somente pela instalação de VRPs. Ressalta que a pressurização de um sistema de distribuição sempre envolve um alto custo, de maneira que a redução de pressões através de VRPs é, intrinsecamente, ineficiente. Na seqüência, cita algumas alternativas a serem consideradas antes de se optar pela instalação de VRPs, como ressetorização e redimensionamento de bombas (BUTLER, 2000).

Thornton (2002) relaciona, no gerenciamento de pressões em sistemas de distribuição, as atividades de redução de pressão, de controle de nível de reservatórios, de controle de vazão e de sustentação de pressões. No entanto, quando fala em controle de nível de reservatórios, não apresenta nenhum estudo conclusivo. 
Ainda sobre gerenciamento de pressões, Thornton (2002, p. 261 - tradução nossa) afirma:

\begin{abstract}
A otimização de sistemas de abastecimento apresenta, em muitos casos, uma relação custo $x$ benefício muito melhor do que a expansão do sistema e, quase sempre, tem um impacto ambiental mais positivo. Muitos sistemas de abastecimento de água são projetados considerando um nível mínimo de pressão requerida para os diversos tipos de demanda mas, em muitos casos, não se faz nenhuma consideração quanto aos níveis máximos de pressão. [...] O gerenciamento de pressões é uma das formas mais básicas e de melhor custo $x$ benefício de otimização de um sistema e pode, em muitos casos, proporcionar rápidos retornos para grandes investimentos.
\end{abstract}

No mesmo tom, Adani (2006 - informação verbal) ${ }^{1}$, apresentando estudo de caso de aplicação de ações para redução e controle de perdas no sistema de distribuição de água da Cidade de Campinas, durante painel sobre o tema "Eficiência Operacional", afirmou que, de todas as ações empreendidas, nos últimos cinco anos, as ações que apresentaram melhores resultados foram o Gerenciamento de Pressões (no controle de perdas reais) e a substituição de hidrômetros de grandes consumidores (no controle de perdas aparentes).

Thornton (2006 - informação verbal) ${ }^{2}$ ressaltou, ainda, apresentando a ilustração reproduzida na Figura 2.5, apresentada na página 38, que a variação de pressão, em uma faixa ampla, é pior para a integridade da rede de distribuição do que uma pressão alta, mantida constante. Sugeriu a abordagem para o gerenciamento de pressões, em que seria realizada, numa primeira etapa, a estabilização das pressões na rede de distribuição e, na seqüência, redução de pressão nos pontos onde a pressão permanecesse elevada.

Farley e Trow (2003, p. 145 - tradução nossa), afirmam a esse respeito:

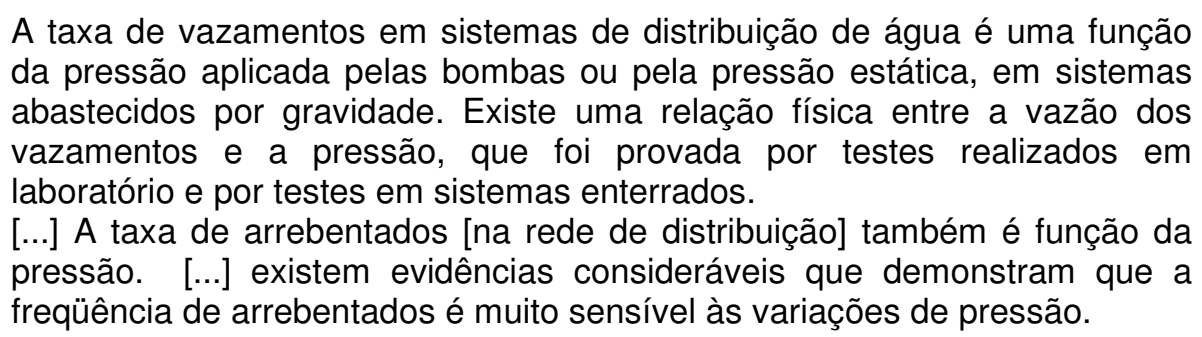

\footnotetext{
${ }^{1}$ Informação fornecida por Lina C. Adani, em Painel sobre Eficiência Operacioal, no XVII Encontro Técnico da Associação dos Engenheiros da Sabesp (AESABESP). São Paulo, 2006.

${ }^{2}$ Informação fornecida por Julian Thornton, no mesmo evento em ${ }^{1}$.
} 
Ainda Farley e Trow (2003, p. 150 - tradução nossa):

[...] As variações ao longo do dia na pressão provocam tensões e deformações nas tubulações da rede [de distribuição]. Podem ocorrer [ainda] danos nas juntas e conexões, podendo ocorrer rompimentos em alguns tipos de tubulação. Os danos podem ser causados pelo efeito de fadiga, que vai se desenvolvendo ao longo do tempo. Quanto maior a faixa de variação de pressão [na rede] e quanto mais freqüentes essas variações, maiores as chances de ocorrerem danos devidos à flutuação de pressão.

O gerenciamento de pressões vai buscar suavizar essas variações, resultando em menos danos à rede [de distribuição] e numa expectativa de vida da rede de distribuição maior.

Nessas afirmações, Farley e Trow ressaltam o caráter preventivo do gerenciamento adequado de pressões que, comprovadamente, evita a ocorrência de surtos e de grandes variações de pressão, na rede de distribuição, ocorrências que, além de poderem provocar novos vazamentos e arrebentados, certamente vão ocasionar, ao longo do tempo, no caso de freqüentes variações de pressão, fadiga no material das tubulações e futuros arrebentados (BUTLER, 2000; THORNTON, 2002; FARLEY e TROW, 2003).

Quanto aos benefícios do gerenciamento de pressões, Farley e Trow (2003) relacionam a, já mencionada, redução na vazão dos vazamentos e arrebentados; a redução de alguns tipos de consumo, em consumidores com abastecimento direto (sem a existência de caixa d'água); a redução na freqüência de ocorrência de vazamentos e arrebentados; a possibilidade de se proporcionar um abastecimento mais constante aos consumidores; o aumento da capacidade de combate a incêndios; e a possibilidade de se prolongar a vida útil dos ativos (rede de distribuição).

Thornton (2002) relaciona, entre os benefícios do gerenciamento de pressões: a redução de vazamentos; a economia de água, nos casos de abastecimento direto da rede; a redução de prejuízos, nos casos de inadimplência (mantendo um nível mínimo de abastecimento); uma melhora na eficiência de distribuição da água; garantia de reservação; redução de impactos hidráulicos resultantes de transientes; e redução nas reclamações dos consumidores.

No entanto, deve-se fazer a ressalva de que o benefício de redução de prejuízos, nos casos de inadimplência, afirmados por Thornton, só seriam alcançados em 
sistemas com abastecimento direto ou reduzindo-se as pressões a níveis inferiores ao mínimo estabelecido pela Norma Brasileira, pressão dinâmica mínima de 100 kPa (ABNT, 1994), sendo objeto desta pesquisa esse tipo de influência em sistemas com características de abastecimento indireto.

\subsubsection{Válvulas Redutoras de Pressão (VRPs)}

A redução de pressões excessivas, amplamente recomendada para 0 gerenciamento adequado de pressões, é, geralmente, implementada através da instalação de válvulas redutoras de pressão.

As válvulas redutoras de pressão (VRPs) são dispositivos mecânicos, utilizados, como acessório, nas redes de distribuição de água, em pontos específicos, para proporcionar uma pressão reduzida a jusante, evitando pressões elevadas, em determinados trechos da rede.

Na Figura 2.7, são apresentadas, a título de ilustração, a fotografia de uma instalação de VRP e um desenho esquemático, de uma VRP com saída fixa de pressão, onde o seu funcionamento básico pode ser entendido da seguinte forma: quando a pressão a jusante da válvula está dentro do limite de pressão para o qual a válvula foi ajustada, o controle de redução de pressão " $\mathrm{C}$ " permanece aberto, permitindo que o diafragma "D" fique livre, abrindo a válvula; quando a pressão a jusante excede o limite de pressão ajustado, o controle de redução de pressão "C" se fecha e pressiona o diafragma "D" para o fechamento da passagem de fluxo.

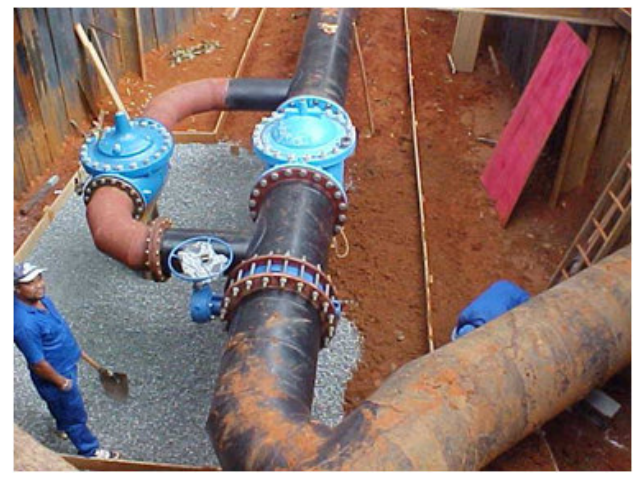

FONTE: SABESP

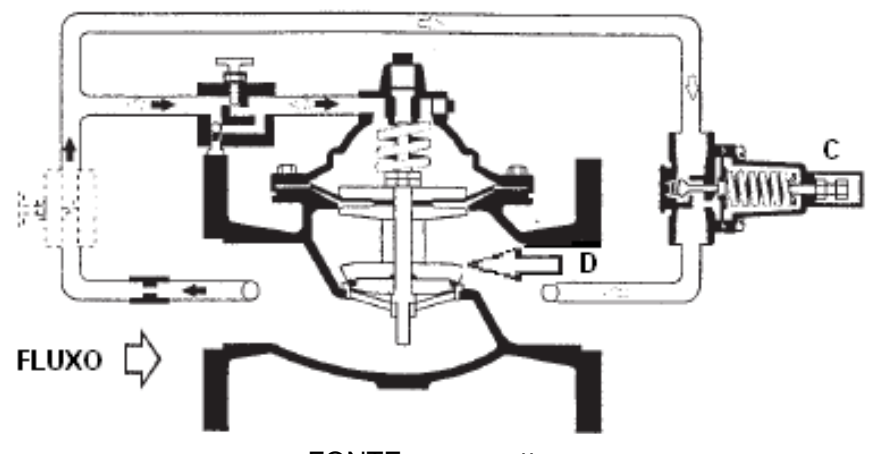

FONTE: www.watts.com

FIGURA 2.7 - Ilustrações de válvulas redutoras de pressão 
Para a instalação de uma VRP é necessário que sejam delineados os limites na rede, instalando-se válvulas de bloqueio, ou novos trechos de tubulação, fechando os limites da área onde se deseja controlar a pressão. Da mesma forma, a área a ser controlada por VRP deverá ter uma única entrada de água, onde é instalada a VRP ou, ter uma VRP instalada em cada ponto de alimentação dessa área.

Nesse contexto Thornton (2006 - informação verbal) ${ }^{1}$ recomenda que, numa primeira etapa, sejam realizadas ações para que se reduzam os valores extremos de pressão na rede, evitando grandes flutuações. Após o controle da faixa de variação de pressões, podem, então, ser instaladas VRPs para redução da pressão nos trechos em que esta permanece elevada.

As VRPs podem ser classificadas quanto ao tipo de controle de saída. A mais comum e mais antiga é a VRP com saída fixa de pressão, onde se estuda o quanto de pressão se pretende reduzir e se estabelece a pressão de saída da válvula, que deve permanecer constante ao longo do tempo.

Com a evolução dos projetos, foram introduzidas as VRPs com controladores automáticos em função do tempo, que são programadas em função de tabelas consumo x tempo, elaboradas com base em curvas típicas de consumo para a área em estudo.

Outro tipo de válvula é a com controle automático em função da vazão. Esse tipo de controle se baseia em tabelas pressão x vazão e abre ou fecha a válvula em função da vazão demandada.

Encontram-se em desenvolvimento válvulas controladas em função da pressão em um ponto crítico, que é o ponto de pressão mínima, na área de rede a ser controlada pela VRP, onde se instala um transdutor de pressão, acoplado a um transmissor de sinais. Esse tipo de controle de VRP é considerado o mais preciso, para sua abertura e fechamento.

A utilização de VRPs, no controle de perdas reais, se baseia em constatações de que o número de arrebentados e a freqüência de ocorrência de vazamentos têm uma relação direta com níveis altos e surtos de pressão, nas redes de distribuição.

\footnotetext{
${ }^{1}$ Informação fornecida por Julian Thornton, em Painel sobre Eficiência Operacioal, no XVII Encontro Técnico da Associação dos Engenheiros da Sabesp (AESABESP). São Paulo, 2006.
} 
Nesse enfoque, é ressaltado o caráter preventivo que as VRPs exercem, com a redução de altas pressões, contribuindo para se evitar o aparecimento de arrebentados na rede e para o prolongamento de sua vida útil, devido à redução dos esforços que podem provocar fadiga mecânica no material da tubulação, ao longo dos anos (BUTLER, 2000; THORNTON, 2002; FARLEY e TROW, 2003).

A redução da pressão a que as redes estão submetidas tem impacto direto, ainda, no volume de perdas por vazamentos não-visíveis e inerentes (vazamentos nãodetectáveis pelos métodos de deteç̧ão conhecidos) e na vazão perdida em arrebentados.

Através de métodos empíricos, John May chegou a relações entre a pressão e a vazão dos vazamentos que seguem a equação $Q_{1} / Q_{0}=\left(P_{1} / P_{0}\right)^{N 1}$, onde: $Q_{1}$ e $Q_{0}$ são as vazões, nos momentos 1 e $0 ; P_{1}$ e $P_{0}$ são as pressões, nos momentos 1 e 0 ; e $\mathrm{N} 1$ é função do material da tubulação e pode variar desde 0,5 , para orifícios, com formato regular, em tubulações de paredes rígidas, até 2,5, para orifícios em tubulações em material flexível, passando por valores intermediários, conforme varia a rigidez do material das paredes da tubulação (THORNTON; LAMBERT, 2005).

Quanto à localização das VRPs, em uma rede de distribuição de água, uma metodologia desejável seria a de se efetuarem simulações de modelagem hidráulica, para se identificarem os pontos ideais para sua instalação. No entanto, dadas as dificuldades na obtenção dos dados necessários a essas modelagens, usualmente procuram-se identificar os trechos de rede com histórico de arrebentados e de vazamentos e com altos níveis de pressão, para se implementarem controles através da implantação de VRPs.

No caso da RMSP, a partir de meados dos anos 90, foi estabelecida uma meta de atendimento com água tratada de $100 \%$ da população residente, nas áreas atendidas pela Sabesp. Para se atingir essa meta, foram sendo prolongadas as redes de distribuição de água, muitas vezes, sem a correspondente setorização, ocasionando muitos pontos abastecidos por derivação em marcha (abastecimento de trechos de rede de distribuição, diretamente das adutoras, sem a construção de reservatórios). Esse tipo de ação, dadas as altas pressões necessárias ao sistema adutor de água, provocou a ocorrência de pressões excessivas em determinados trechos de rede, obrigando a adoção de válvulas redutoras de pressão, como 
solução mais rápida e economicamente mais vantajosa, pelo menos no curto e médio prazos. A outra solução possível, nesses casos, seria a ressetorização desses trechos de rede, que é muito custosa, comparada com a solução de VRPs, além de ser de implantação bem mais demorada, uma vez que, além da construção de trechos de rede e da instalação de válvulas de bloqueio, requer a construção de reservatórios de distribuição.

Dessa forma, na RMSP, área do estudo de caso da presente pesquisa, encontramse instaladas um total de 832 VRPs (informação fornecida pela Sabesp - base: dez./2005), distribuídas entre as cinco unidades de negócio (Centro, Norte, Sul, Leste e Oeste), da Diretoria Metropolitana da Sabesp.

O número crescente de VRPs instaladas na RMSP se deve à busca, pelas unidades de negócio da Diretoria Metropolitana da Sabesp, da minimização dos trechos de rede de distribuição onde ocorrem pressões excessivas, proporcionando níveis de pressão mais adequados.

Na Figura 2.8, é apresentado um gráfico que mostra a evolução do número de VRPs, instaladas pela Sabesp na rede de distribuição de água da RMSP.

O número considerável dessas válvulas, instaladas na rede de distribuição da RMSP, como um todo, reforça a importância da pesquisa em pauta, onde são contemplados dados de consumo, tanto de áreas de VRP com saída fixa de pressão, quanto de áreas de VRP com controle automático de pressão (por tempo e por vazão).

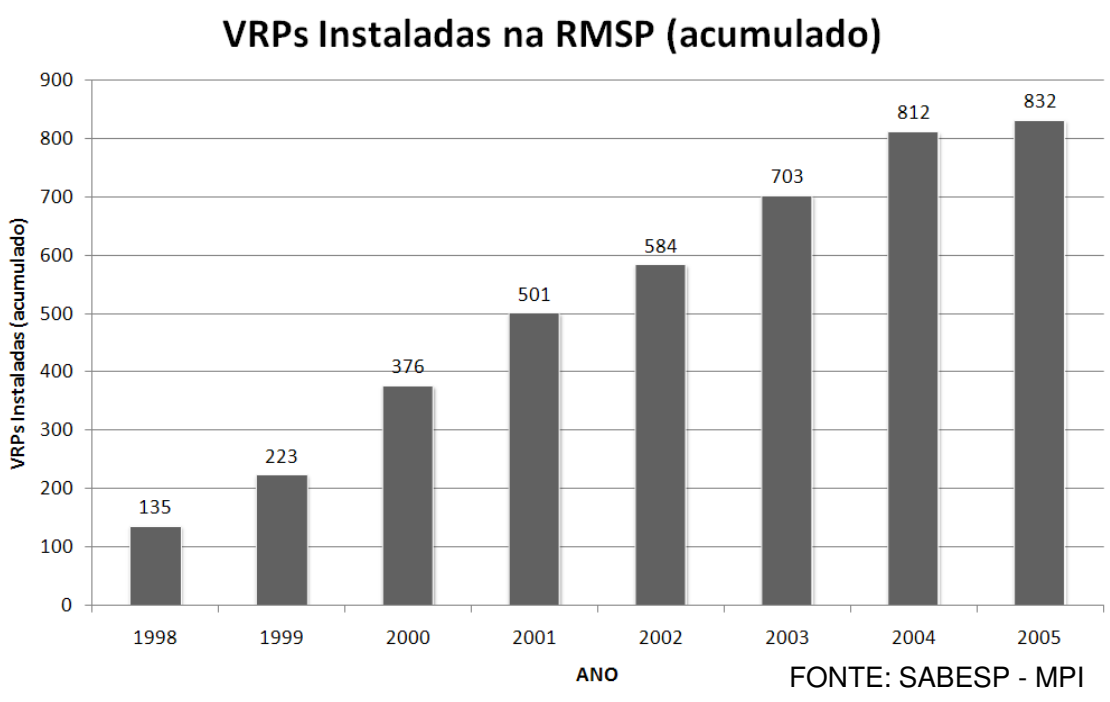

FIGURA 2.8 - Evolução do número de VRPs instaladas na RMSP 
2.2.3 Efeitos da Redução de Pressão, no Consumo das Ligações de Água

Para avaliação dos efeitos da redução de pressão aplicada à rede de distribuição, no nível de consumo das ligações de água, é importante que se caracterize o tipo de abastecimento que é feito às ligações.

Thornton (2006 - informação verbal) ${ }^{1}$ apresenta dois esquemas, reproduzidos nas figuras 2.9 e 2.10, onde são representados os dois tipos básicos de abastecimento, quando se consideram as instalações hidráulicas nos consumidores.

O primeiro, apresentado na Figura 2.9, representa o chamado abastecimento indireto ou, predominantemente indireto, onde apenas alguns pontos de consumo são abastecidos diretamente pela rede de distribuição, sendo a maior parte abastecida através de reservatório interno, as chamadas "caixas d'água", localizado em ponto elevado.

Situação Típica de Abastecimento Residencial no Brasil

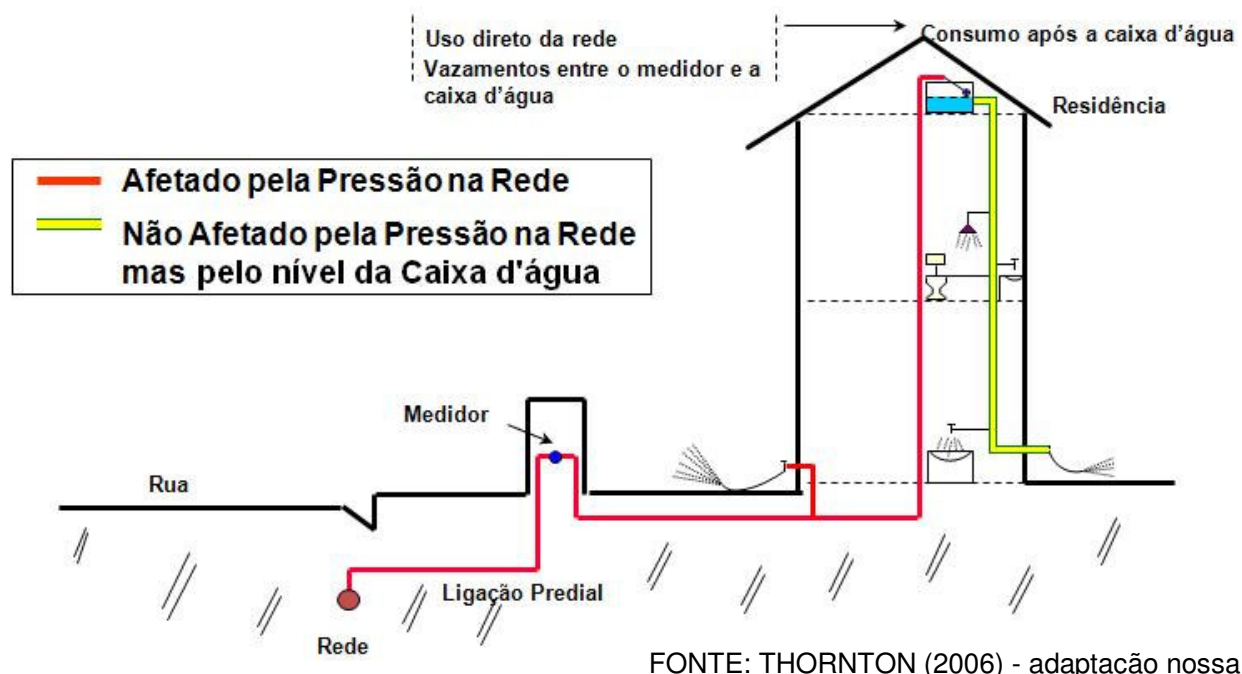

FIGURA 2.9 - Instalação hidráulica com abastecimento indireto

O segundo, apresentado na Figura 2.10, representa o chamado abastecimento direto, onde todos os pontos de consumo são alimentados por tubulação conectada diretamente à rede de distribuição.

\footnotetext{
${ }^{1}$ Informação fornecida por Julian Thornton durante Seminário Internacional de Eficiência Operacional em Sistemas de Água. São Paulo: Sabesp, 2006.
} 


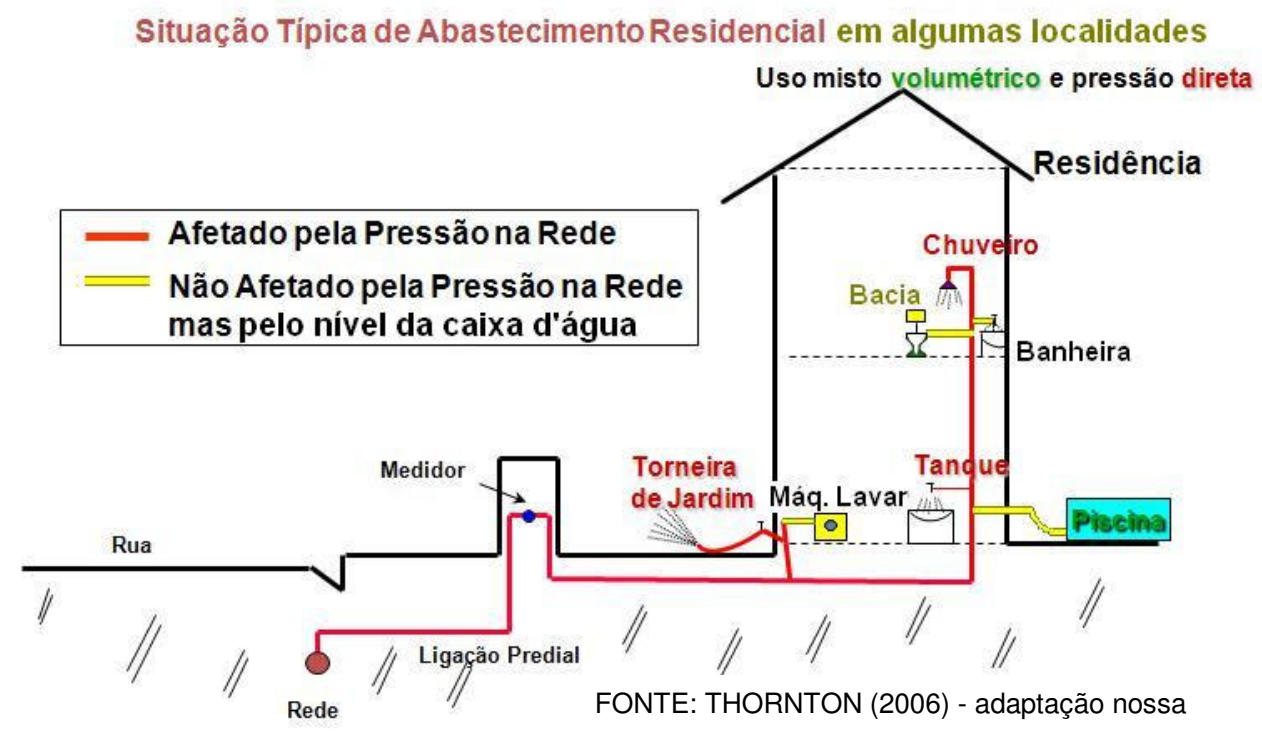

FIGURA 2.10 - Instalação hidráulica com abastecimento direto

Quanto aos efeitos da redução de pressão no volume consumido, Farley e Trow (2003, p. 147 - tradução nossa) afirmam que:

[...] A redução de pressão pode reduzir alguns tipos de consumo. Qualquer consumo, de pontos de consumo conectados diretamente à rede de distribuição, vai apresentar uma redução de vazão, quando submetido a uma pressão reduzida. Exemplos incluem torneiras, chuveiros e mangueiras de jardim. Vasos sanitários que utilizam válvula de descarga, ao invés de caixa acoplada, também apresentam uma redução no consumo.

[...] [No entanto] Se os pontos de consumo estão conectados a uma caixa d'água, não deve ocorrer nenhum impacto devido à redução de pressão. Dessa forma, é importante o conhecimento do tipo de sistema de abastecimento das economias, predominante na área do sistema de distribuição, quando for feita a avaliação dos efeitos do gerenciamento de pressões no consumo.

Farley e Trow (2003) afirmam, ainda, que, apesar da existência de caixa d'água, a redução de pressão pode provocar um impacto positivo na redução de consumo, quando se considera a vedação das torneiras de bóia, dispositivo que controla a entrada de água nas caixas d'água. Afirmam que, em sistemas de distribuição submetidos a altas pressões, existe uma maior tendência da torneira de bóia não vedar perfeitamente o fluxo, quando a caixa d'água está cheia, aumentando o volume nesses reservatórios entre intervalos de consumo de água. Com a redução de pressão, existe uma maior probabilidade que as torneiras de bóia vedem o fluxo com perfeição. Este argumento é semelhante ao utilizado por Thornton (2002). 
No entanto, a NBR 14534 (ABNT, 2000), afirma que "a torneira de bóia submetida à pressão estática de $1.500 \mathrm{kPa}$ [cerca de $150 \mathrm{mca}$ ] deve ser capaz de fechar normalmente e, estando fechada, em repouso, não apresenta qualquer vazamento [...]". Como as pressões extremas, encontradas nas redes de distribuição da RMSP, são da ordem de 100 mca, o argumento utilizado para justificar tal benefício, em princípio, pode não se aplicar no caso da RMSP. Talvez, golpes provocados por transientes hidráulicos, transmitidos à tubulação interna aos imóveis dos consumidores, possam provocar tal efeito.

Fazendo considerações sobre alegadas perdas de faturamento, com a redução na pressão de abastecimento provocada pela instalação de VRPs, Thornton (2002, p. 266 - tradução nossa) afirma:

Quando se voltam as atenções para a perda de faturamento, em sistemas [de distribuição] com alto índice de vazamentos, o gerenciamento de pressões vai sempre trazer benefícios positivos, mesmo quando confrontado com a potencial perda de receita devida à redução de pressão [no abastecimento] de residências e indústrias. Qualquer perda de faturamento deve estar incluída nas análises de custo $\mathrm{x}$ benefício, como um custo inerente ao projeto, da mesma forma que os custos de implantação [de componentes no sistema] e de produção de água. [...] Em situações onde a perda de faturamento não pode ser tolerada, o gerenciamento de pressões pode ser limitado ao período noturno, quando os consumos legítimos estão no seu nível mais baixo e as pressões no sistema no seu nível mais alto.

[...] [Em alguns casos] Os benefícios potenciais da redução de perdas comparados com as [possíveis] reduções de faturamento podem ser analisados.

O fato de Thornton mencionar "potencial perda de receita", deixa transparecer que a informação de que a redução de pressão provoca redução no consumo e conseqüente perda de receita ainda não é um fato comprovado, carecendo de estudos mais consistentes a esse respeito

\subsection{DISPOSITIVOS QUE INFLUENCIAM O REGISTRO DO CONSUMO DE ÁGUA}

Como no sistema de distribuição de água da RMSP o gerenciamento de pressões tem se restringido, num caso mais geral, à instalação de boosters e de VRPs, sendo que somente a instalação de VRPs tem sido utilizada como ferramenta para o controle de perdas, o foco proposto para a presente pesquisa é o de avaliar o efeito 
da redução de pressão, provocada pela entrada em operação de VRPs, no consumo da área de distribuição a jusante do ponto de instalação dessas válvulas, em algumas áreas selecionadas.

\subsubsection{Configuração de Sistemas de Distribuição em outros Países}

Muitos dos autores citados baseiam suas considerações em resultados de experiências em trabalhos realizados em países com sistemas de distribuição de água com configuração diversa da configuração encontrada na RMSP.

Grande parte dos sistemas de distribuição de água europeus, não possui, por exemplo, a característica do uso de reservatório, interno aos imóveis dos consumidores (caixa d'água).

Quanto à hidrometração de consumos, no Reino Unido, por exemplo, ainda hoje, uma porcentagem muito baixa de consumidores possui medidores instalados em suas ligações. De acordo com relatório, publicado em 2005 pelo Ofwat (Office of Water Service), agência reguladora das companhias de água e esgotos na Inglaterra e País de Gales, por exemplo, a média de hidrometração naqueles países era de $8 \%$, no ano fiscal 1996-1997, de $19 \%$, no ano fiscal $2000-2001$, atingindo $26 \%$, no ano fiscal 2004-2005 (OFWAT, 2005).

Abordando o fato da baixa hidrometração de consumo, na Inglaterra e País de Gales, o Ofwat (2005, p. 44 - tradução nossa) afirma:

Pelo fato de apenas $26 \%$ das economias na Inglaterra e País de Gales possuírem medidores [instalados], o consumo do restante das economias precisa ser estimado. Essa estimativa é feita, principalmente, através de pontos de monitoramento de consumo per capita não-medido [upcc]. Esses pontos de monitoramento podem ser divididos em dois tipos principais:

- pontos de monitoramento de área; e

- pontos de monitoramento de economias individuais.

Os pontos de monitoramento de área medem a vazão de água que entra em áreas distintas. Após a dedução dos [volumes de] consumos medidos, dos [volumes de] usos que não são das economias e dos [volumes de] vazamentos, o volume consumido pode ser dividido entre a população, para se chegar ao valor do consumo per capita na área. Os pontos de monitoramento de economias individuais medem [o consumo de] cada consumidor numa amostragem direta mas, ainda assim, os consumidores são cobrados na mesma forma de rateio que na de consumo não medido. Dividindo o volume de consumo [da economia] pelo número de ocupantes, tem-se o valor do consumo per capita. Os resultados desses 
monitoramentos são extrapolados pela área de distribuição de cada companhia, utilizando fatores como:

- tipo da economia

- ocupação [número de ocupantes]

- valor de rateio [RV - estipulado até 1990, por um órgão específico, como base para cobrança de impostos]; e

- indicadores sócio-econômicos.

[...] A medição individual [do consumo das economias] e uma estrutura de tarifas sensível podem desempenhar um papel importante como parte da estratégia de gestão da demanda, particularmente em relação aos consumidores que utilizam uma grande quantidade de água para finalidades não-domésticas [enchimento de piscinas ou regas de jardins, por exemplo]. $[\ldots]$

Levando-se em consideração a forma como é feito o rateio dos consumos naqueles países, pode-se considerar que as componentes de perdas aparentes, relativas a submedição em hidrômetros e a consumos não-autorizados, que respondem por uma parcela considerável das perdas em sistemas de distribuição como o da RMSP, não afetam o faturamento das companhias de distribuição de água. A única parcela de perdas aparentes, naquela configuração de sistema, seria a relativa às imprecisões de medição dos macromedidores utilizados para medir as vazões afluentes aos setores e distritos de medição (DMAs).

Pode-se considerar, ainda, que os desperdícios dos consumidores (uso excessivo de água) e as perdas aparentes estão presentes nas medições feitas na entrada dessas áreas e têm os seus custos rateados entre os consumidores daquela área. Situação semelhante à que ocorre em ligações de água em condomínios, na RMSP.

\subsubsection{Hidrômetros}

São chamados de hidrômetros, os medidores utilizados para se medir o consumo de água, em imóveis abastecidos por ligação de água da rede de distribuição.

A Norma Brasileira define o medidor de água como o "instrumento destinado a indicar e totalizar continuamente o volume de água que o atravessa" (ABNT, 1999).

Na RMSP, de uma maneira geral, o hidrômetro utilizado nas instalações hidráulicas dos consumidores é do tipo velocimétrico que, ainda na definição da Norma Brasileira, é um "instrumento instalado num conduto fechado, que consiste de um 
elemento móvel acionado diretamente pela velocidade do fluxo da água, cujo movimento é transmitido por meios mecânicos ou outros, ao dispositivo indicador que totalizam o volume" (ABNT, 1999).

Os hidrômetros são, normalmente, classificados pela sua vazão nominal $\left(0,75 \mathrm{~m}^{3} / \mathrm{h}\right.$; $1,5 \mathrm{~m}^{3} / \mathrm{h} ; 3,0 \mathrm{~m}^{3} / \mathrm{h}$; etc.), definida na seqüência, e pela sua classe metrológica, $A, B$ ou $\mathrm{C}$, sendo a última a de maior exatidão, entre essas três.

Na RMSP, nas áreas com rede de distribuição de água operadas pela Sabesp, o hidrômetro mais comumente encontrado, nas cerca de três milhões e novecentas mil ligações, é o de vazão nominal de $1,5 \mathrm{~m}^{3} / \mathrm{h}$, classe $B$.

As principais características de um hidrômetro são:

- vazão máxima, ou de sobrecarga $\left(Q_{\max }\right)$ : maior vazão admissível no medidor, com a qual pode operar por curto espaço de tempo sem ser danificado (RECH, 1992; ABNT, 1999);

- vazão nominal, ou permanente $\left(Q_{n}\right)$ : corresponde à metade da vazão máxima, sendo aquela até a qual o medidor pode funcionar de forma satisfatória, sob condições normais (RECH, 1992; ABNT, 1999);

- vazão mínima $\left(Q_{\min }\right)$ : a menor vazão em que o medidor deve registrar, sem que os erros sejam maiores que o máximo admissível (ABNT, 1999);

- vazão de transição $\left(\mathrm{Q}_{\mathrm{t}}\right)$ : vazão situada entre a máxima e a mínima, na qual o campo de medição se divide em zona superior e zona inferior, cada uma caracterizada pelo valor de erro máximo admissível (ABNT, 1999);

- vazão de início de movimento: vazão a partir da qual o hidrômetro começa a indicar movimento das partes móveis; é a menor vazão possível capaz de vencer todas as resistências passivas do mecanismo, fazendo girar a turbina e as demais peças, começando a registrar consumo (RECH, 1992).

Rech (1992) ressalta que, entre o início do movimento e a vazão mínima, o medidor não trabalha dentro dos erros tolerados pela Norma, registrando consumo abaixo do consumo real. A esse consumo registrado abaixo do consumo real é dado o nome de volume de submedição.

Como apresentado no item 2.1.1, o volume de submedição é um dos componentes responsáveis pelas perdas aparentes de água. 
Estudo realizado pelo Instituto de Pesquisas Tecnológicas (IPT), contratado pela Sabesp, fazendo uma avaliação do índice de submedição médio nos hidrômetros instalados na RMSP, a partir de estudo piloto na Unidade de Negócio Oeste, chegou a um índice médio de submedição para o parque de hidrômetros instalado na RMSP, com relação ao volume efetivamente consumido (quantidade real de água consumida), da ordem de $15 \%$, e da ordem de $17 \%$, com relação ao volume micromedido (IPT, 2007).

Fantozzi (2007 - informação verbal) ${ }^{1}$ apresentou curva de submedição elaborada a partir de levantamento na Região da Emilia-Romagna, no Norte da Itália, em que hidrômetros classe $\mathrm{C}$, em imóveis com abastecimento direto, chegam a apresentar um índice de $12 \%$ de submedição.

Rizzo e Cilia (2005) apresentam estudo em que, utilizando hidrômetros de alta precisão (volumétricos - classe D), chegam a um índice de submedição médio, em relação ao consumo total (efetivo) dos imóveis avaliados, de 6\%. Com isso, conseguem demonstrar o efeito das baixas vazões, permitidas pela torneira de bóia que controla o fluxo de entrada de água nas caixas d'água, na submedição em hidrômetros.

Convém ressaltar que o tipo de torneira de bóia, utilizado para controle de vazão na entrada das caixas d'água, é um fator preponderante quando se consideram as perdas por submedição. Quando o foco é a redução de pressão de distribuição, provocada pela instalação de VRPs, o tipo de torneira de bóia não exerce influência no nível de consumo, uma vez que a vazão, nos pontos de consumo internos aos imóveis, passa a ser controlada pelo nível da água na caixa d'água e não pela vazão permitida pela torneira de bóia.

Na Figura 2.11, é apresentado um diagrama que representa uma curva típica de erro em hidrômetros.

\footnotetext{
${ }^{1}$ Informação fornecida por Marco Fantozzi (IWA) durante apresentação sobre avanços no controle de perdas na Itália, realizada na Unidade Consolação da Sabesp, São Paulo, em abril de 2007.
} 


\section{Curva de Erros}

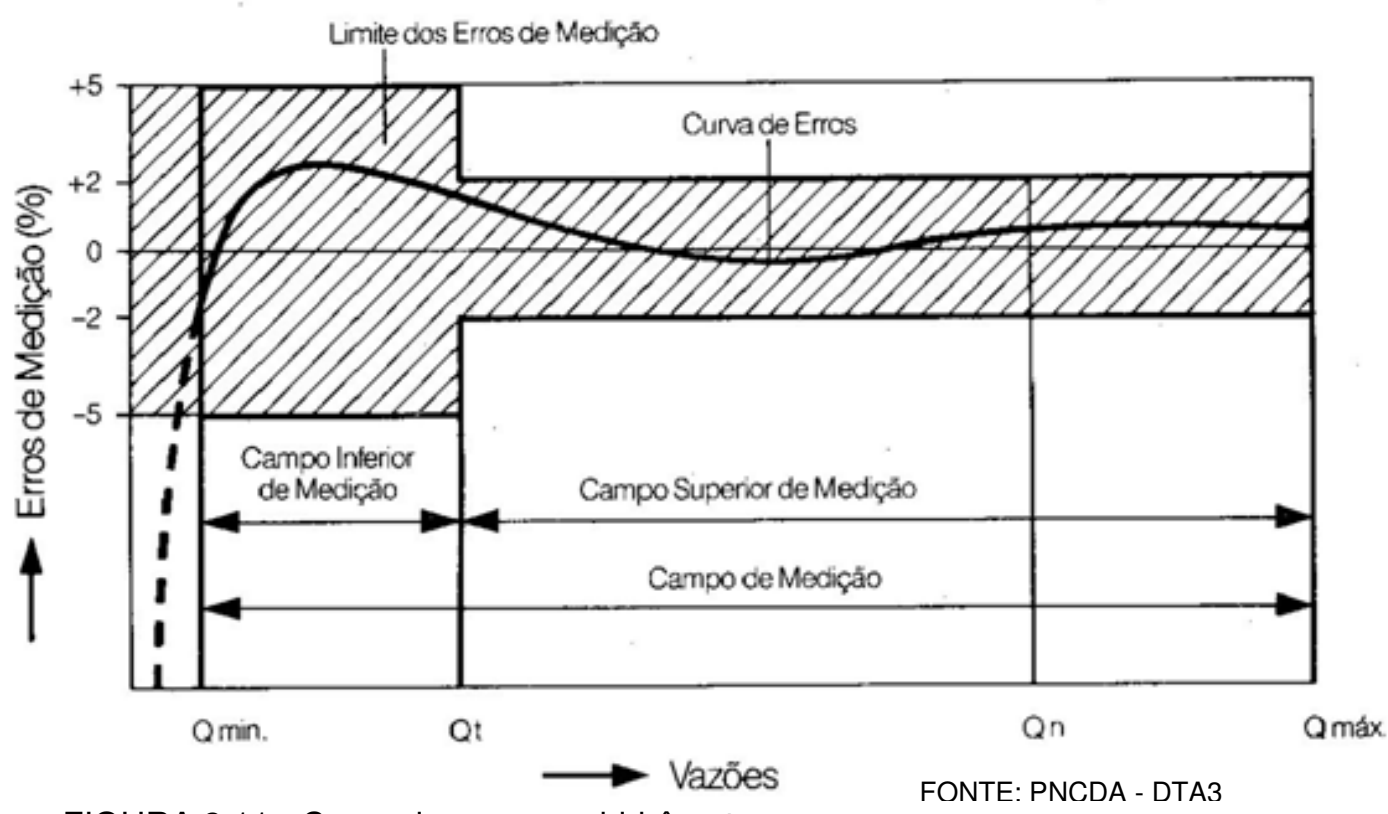

FIGURA 2.11 - Curva de erros em hidrômetro

Cabe, ainda, destacar que a existência de hidrômetros nos consumidores representa, em última instância, uma ação muito eficiente para o uso racional da água, pois estudos comprovam que o hidrômetro se constitui num dispositivo inibidor de consumo. Quanto a esse aspecto, a agência reguladora das companhias de água e esgotos na Inglaterra e País de Gales, Ofwat, apresenta, em sua página na Internet (www.ofwat.gov.uk), o documento "Water Metering: Position Paper", em que órgão manifesta a sua visão do problema, da seguinte maneira: "[...] A medição do consumo é particularmente importante em áreas onde os recursos hídricos são mais escassos [...] Consumidores que possuem medidores instalados tendem a utilizar menos água do que aqueles que são cobrados por um valor baseado em rateio [...]" (Ofwat, 2006).

Ainda na Inglaterra, em notícia veiculada em 1/2/2007, sob o título "Companhias de água devem receber poder para forçar a instalação de medidores de água nos consumidores, segundo plano publicado esta semana pelo Defra" (tradução nossa), a página da Internet especializada em meio-ambiente e recursos naturais "Edie.net" (www.edie.net) informa que o Defra - Department for Environment, Food and Rural Affairs (departamento que controla as matérias referentes ao meio-ambiente, alimentação e produção rural, no Reino Unido - www.defra.gov.uk) publicou um 
plano em que se planeja criar mecanismos para que as companhias que operam sistemas de distribuição de água, no Reino Unido, possam instalar, compulsoriamente, medidores de água nos consumidores. Segundo o artigo, a instalação de medidores tem mostrado que o uso da água cai em torno de $10 \%$, fazendo com que os consumidores fiquem mais atentos ao uso que se faz da água. Informa, ainda, que o Ministro do Meio-Ambiente lan Pearson disse: "[...] Em áreas onde os recursos hídricos são escassos, a medição [individual] do consumo de água pode se tornar uma ferramenta adicional valiosa [...] através da redução do uso desnecessário e desperdício de água".

\subsubsection{Caixa d'água}

Para a presente pesquisa, a caixa d'água (reservatório interno predial) é um componente-chave, uma vez que a sua existência, nas instalações hidráulicas dos consumidores, é que caracteriza o sistema de abastecimento como indireto, como na configuração mais geral encontrada na RMSP, área do estudo de caso. Sistemas de distribuição que não possuem esse reservatório interno na instalação hidráulica dos consumidores são classificados como de abastecimento direto.

Como mencionado anteriormente, o nível de água na caixa d'água é que controla a pressão, nos pontos de consumo internos aos imóveis, abastecidos por sistema indireto, e, conseqüentemente, a pressão que influirá no nível de consumo total do imóvel, independentemente da pressão de distribuição de água aplicada no ponto de entrada da sua instalação hidráulica. Somente os pontos de consumo, internos ao imóvel, abastecidos diretamente pela rede de distribuição é que terão sua vazão controlada pela pressão na entrada da instalação hidráulica.

Na Figura 2.12, é apresentado um desenho esquemático do conjunto caixa d'água / torneira de bóia. 


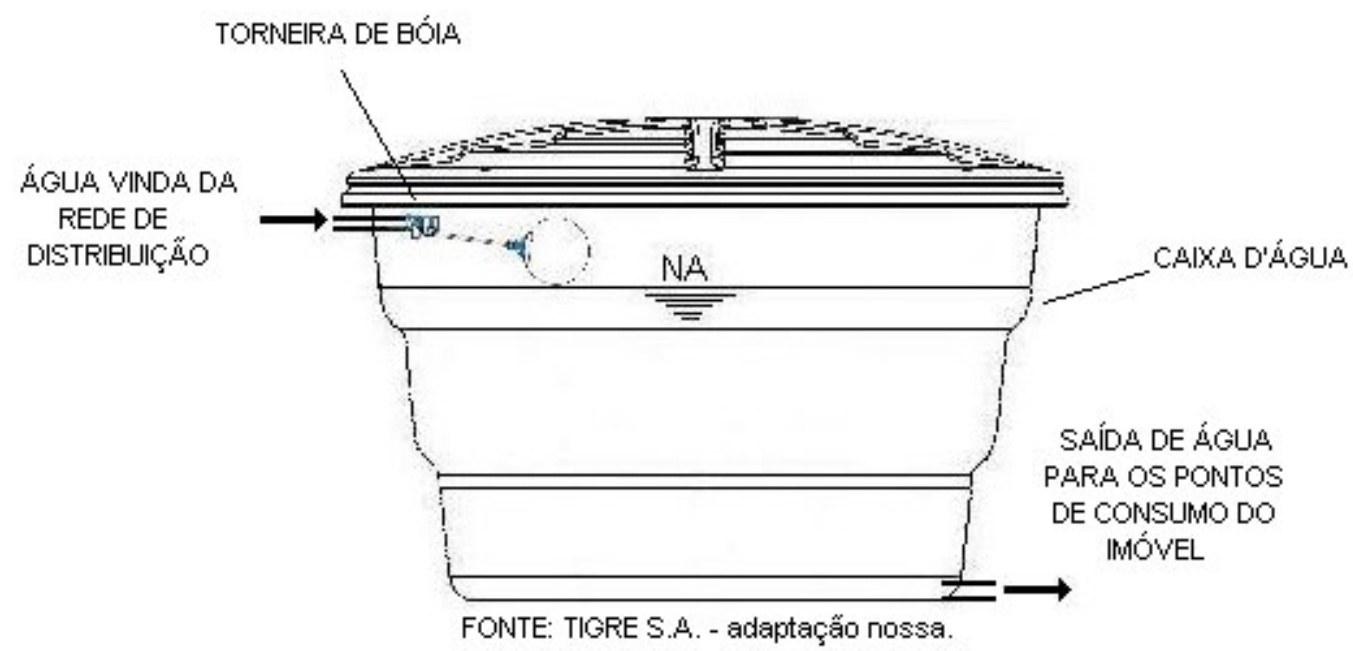

FIGURA 2.12 - Desenho esquemático do conjunto caixa d'água + torneira de bóia

\subsection{CARACTERÍSTICAS DE CONSUMO}

Quando se planeja, se projeta ou se gerencia um sistema de abastecimento de água, é fundamental que se avalie a quantidade de água requerida para o atendimento dos usos múltiplos (incluindo as perdas no sistema) que se espera da água distribuída, que corresponde à demanda de consumo (GOMES, 2004; TSUTIYA, 2004).

Para o entendimento do trabalho em questão, é importante que se diferenciem os tipos de consumo que são objeto das análises efetuadas.

Quando se fala em consumo e em medição de volumes consumidos, devem ser distinguidos dois tipos básicos. O primeiro se refere aos volumes aduzidos aos reservatórios de distribuição e medidos na sua entrada, cuja totalização é chamada de volume macromedido no sistema. O segundo se refere ao consumo medido nos hidrômetros instalados nas ligações de água dos consumidores do sistema de distribuição e sua totalização é chamada de volume micromedido no sistema.

Do ponto de vista do volume aduzido aos reservatórios de distribuição, o consumo registrado por esses medidores engloba os consumos micromedidos nas ligações de cada consumidor, os consumos autorizados não-cobrados (usos operacionais; usos emergenciais; e usos sociais) e as perdas de água, que compreendem as perdas 
reais e as perdas aparentes, definidas anteriormente. Em cidades da Inglaterra, por exemplo, são utilizados os volumes macromedidos nas entradas das áreas de distribuição para a cobrança pelo consumo de água, através de rateio, pois o nível de hidrometração das ligações, naquele País, é muito reduzido.

A título de exemplo, no gráfico representado na Figura 2.13 são apresentadas curvas de vazão média horária, registradas na entrada de área onde foi instalada uma VRP. A primeira curva representa a vazão média horária, no período anterior à redução na pressão de distribuição, provocada pela instalação da VRP. A segunda, curva, num nível inferior, representa a vazão média horária, registrada após a implementação da redução de pressão.

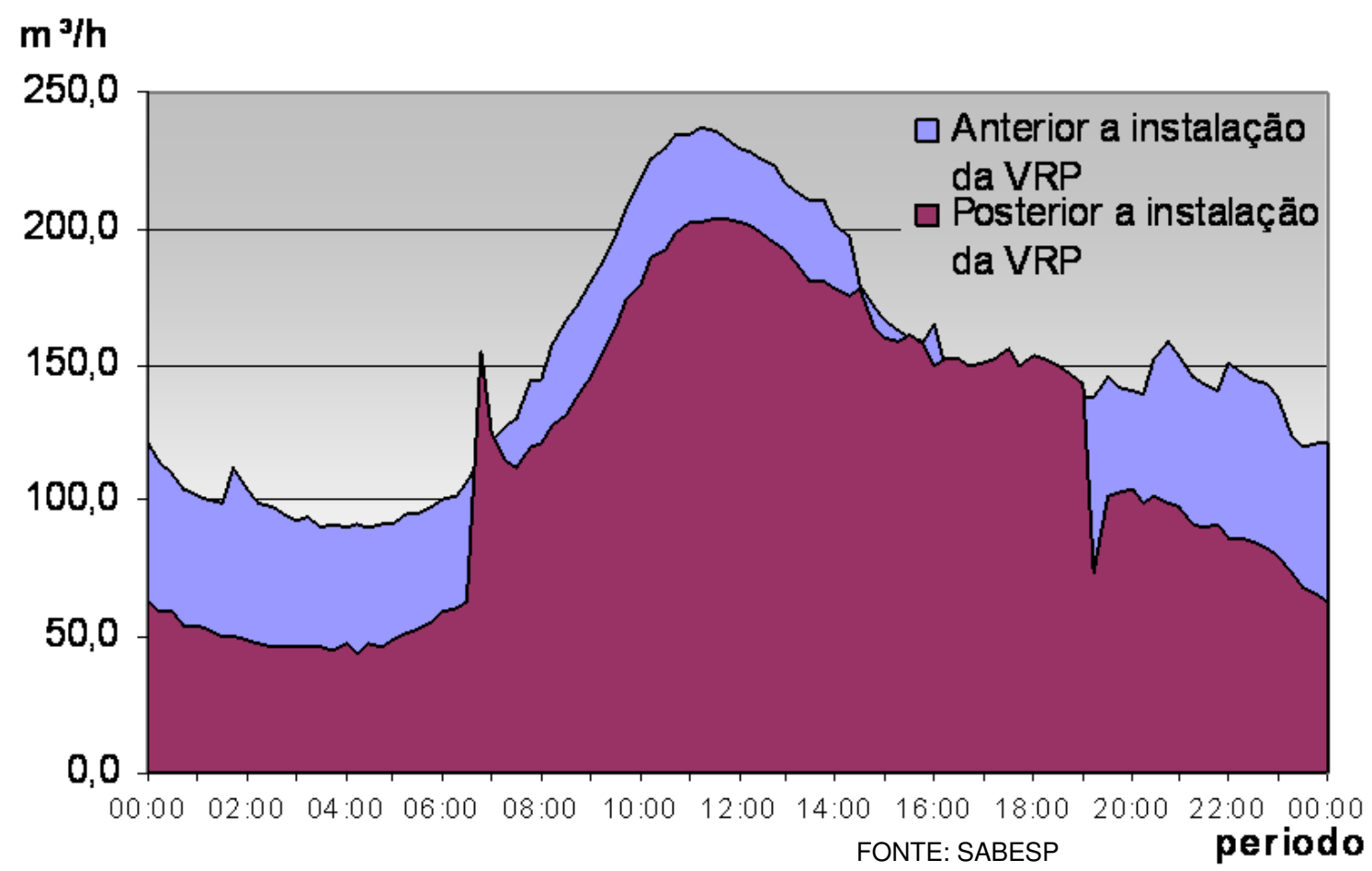

FIGURA 2.13 - Vazão medida antes e após redução de pressão aplicada por VRP

Nas curvas apresentadas na Figura 2.13, pode-se constatar que houve uma redução na vazão média horária macromedida, após a efetivação da redução de pressão de distribuição de água.

Ressalta-se que nessa vazão macromedida, estão presentes os consumos nas ligações de água e os volumes de perdas naquela área. 
O presente trabalho pretende avaliar como foram afetados os consumos, especificamente, das ligações de água, na situação antes x depois da redução de pressão implementada.

Quanto aos usos que se faz da água distribuída, o consumo pode ser classificado em residencial, comercial, público e industrial (TSUTIYA, 2004). As áreas comerciais da Sabesp incluem, ainda, a categoria de uso misto, quando um imóvel possui ligação classificada com mais de um dos usos relacionados por Tsutiya.

As participações percentuais das economias da RMSP, quanto ao tipo de uso, são apresentadas na Figura 2.14, que mostra a participação de cada categoria, conforme o número de ligações de água, e, na Figura 2.15, que mostra a participação de cada categoria de uso, conforme o volume consumido. É importante destacar que o conceito utilizado para economia, nesse contexto, é o de uma unidade de consumo de água, sendo que, no caso de condomínios, por exemplo, uma única ligação de água abastece diversas economias.

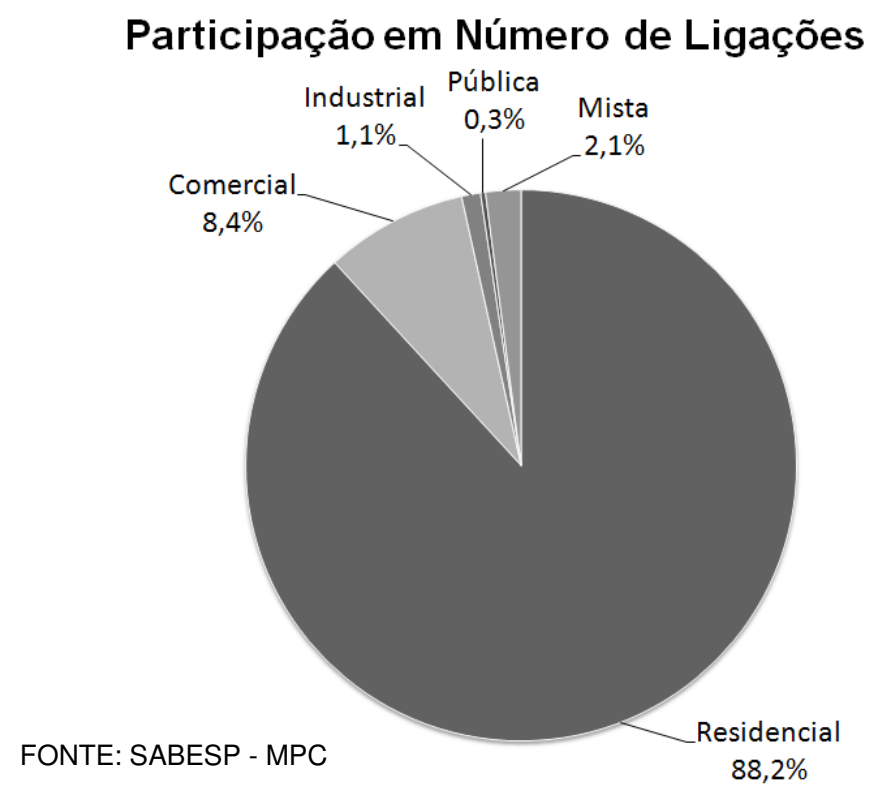

FIGURA 2.14 - Distribuição da quantidade de ligações, na RMSP, conforme o tipo de uso março de 2007 


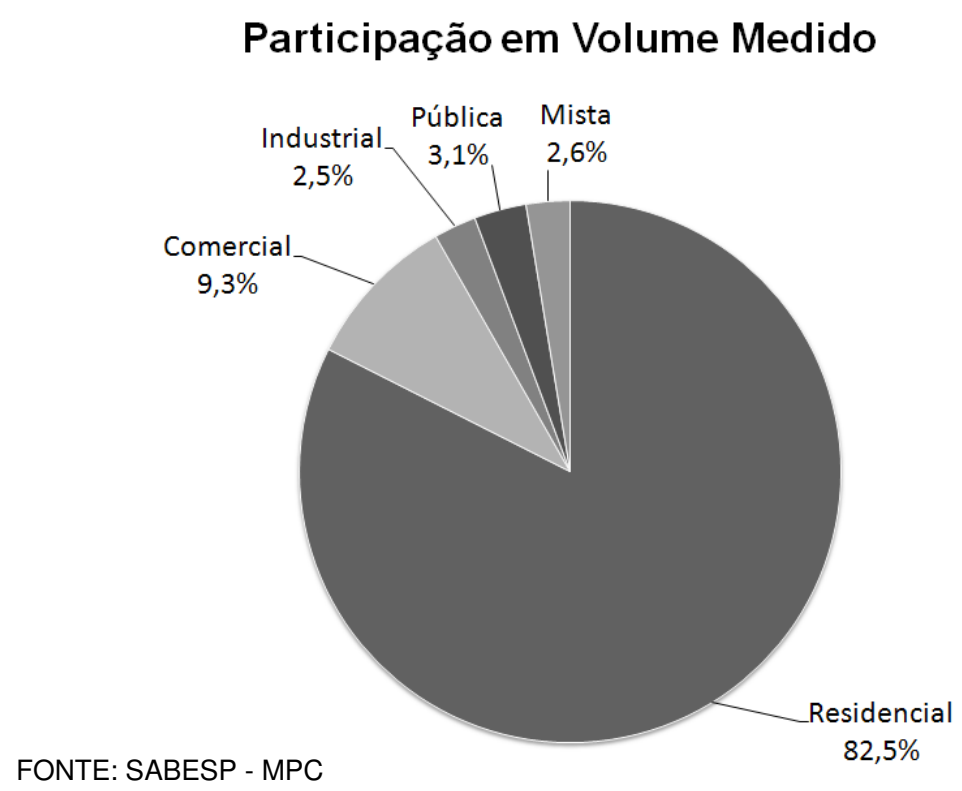

FIGURA 2.15 - Distribuição do volume medido em ligações, na RMSP, conforme o tipo de uso - março de 2007

Com relação ao consumo residencial, Yoshimoto e Silva (2001 apud TSUTIYA, 2004) apresentaram uma distribuição média de consumo em residências da RMSP, que é apresentada na Figura 2.16.

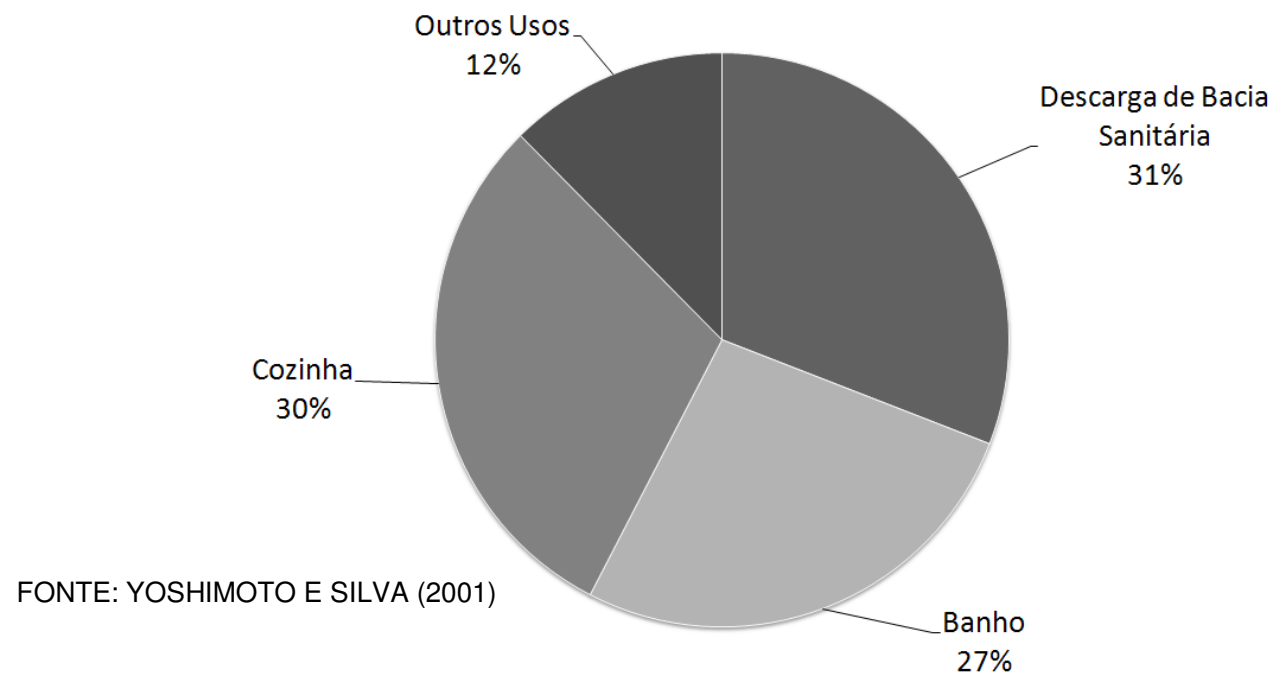

FIGURA 2.16 - Principais usos residenciais na RMSP - 2001

Quanto ao consumo per capita, na RMSP, são apresentados, no Quadro 2.1, os consumos de água médios per capita, das economias residenciais, além dos 
consumos médios por ligação de água e dos consumos médios por economia, em cada uma das regiões, durante $o$ ano de 2005. Esses indicadores foram calculados a partir de dados de relatórios da Sabesp (SABESP - MPI, 2007; Relatórios de Informações Comerciais On-Line, do MPC - intranet Sabesp).

Quadro 2.1 - Dados de consumo de água médio, na RMSP (ano base: 2005)

\begin{tabular}{cccc}
\hline $\begin{array}{c}\text { Região } \\
\left(^{*}\right)\end{array}$ & $\begin{array}{c}\text { Consumo } \\
\text { Per Capita } \\
\text { (L/habitante/dia) }\end{array}$ & $\begin{array}{c}\text { Consumo } \\
\text { por Ligação } \\
(\text { L/ligação/dia })\end{array}$ & $\begin{array}{c}\text { Consumo } \\
\text { por Economia } \\
\text { (L/economia/dia) }\end{array}$ \\
\hline Centro & 250 & 1.080 & 510 \\
Norte & 140 & 590 & 440 \\
Sul & 130 & 620 & 440 \\
Leste & 110 & 520 & 390 \\
Oeste & 150 & 710 & 460 \\
RMSP (médio) & 150 & 700 & 450 \\
\hline
\end{tabular}

$\left({ }^{*}\right)$ Nas áreas abastecidas diretamente pela Sabesp.

FONTE: SABESP - MPC/MPI

$\left({ }^{* *}\right)$ Calculado com base no consumo medido em economias residenciais.

O termo "consumo de água médio" se refere à forma como foram calculados os indicadores de consumo, na qual o volume total de consumo medido, nas ligações residenciais, ao longo do ano de 2005, foi dividido, respectivamente, pelo número de habitantes de cada região, pelo número total de ligações, em cada região, e pelo número total de economias, em cada uma das regiões. Dessa forma, o consumo per capita apresentado não representa, com exatidão, o consumo interno nas economias residenciais, mas um valor médio de rateio do consumo total pela população.

Convém destacar, ainda, que o consumo médio das ligações de água é influenciado por diversos fatores, sendo os mais importantes: condições climáticas; hábitos de consumo e nível sócio-econômico da população; natureza da cidade (industrial, turística, dormitório, etc.); existência de medidores de consumo; pressão na rede; existência de rede de esgotos; e preço da água (GOMES, 2004; TSUTIYA, 2004).

Ressalve-se que a influência da pressão na rede sobre o consumo das ligações, citada tanto por Gomes (2004), quanto por Tsutiya (2004), é objeto do presente estudo e deve ser considerada, em princípio, somente nos pontos de consumo com abastecimento direto da rede de distribuição. 
Quanto aos fatores que influenciam o perfil de consumo das economias, cabe, ainda, a observação de que, no caso de condomínios (verticais ou horizontais), onde a medição de água é feita através de um único medidor instalado na entrada de água para a rede de distribuição interna a esses condomínios, o consumo per capita tende a ser mais elevado que na média das economias, uma vez que os custos dos usos excessivos de água são rateados entre todos os condôminos. Daí, a crescente mobilização, em muitas cidades do Brasil, buscando estabelecer regras, metodologias e legislação, regulamentando e incentivando a chamada medição individualizada de consumo de água (COELHO; MAYNARD, 1997; ANA, 2004) ${ }^{1}$.

Certamente o fator citado no parágrafo anterior tem forte influência no consumo per capita médio da Região Centro da RMSP, pois aquela Região é a que possui maior concentração de economias verticalizadas (SABESP - MPI, 2006).

Dada a influência dos diversos fatores relacionados, parece lógico que para o abastecimento de água, em uma determinada localidade, ocorram variações anuais, mensais, diárias e horárias no consumo de água (GOMES, 2004; TSUTIYA, 2004).

Portanto, para que se faça uma previsão adequada do consumo em determinada região, é importante que se conheçam as suas curvas de consumo e se determinem seus coeficientes de variação de consumo, $\mathrm{K} 1$, para o dia de maior consumo, e K2, para a hora de maior consumo, além do coeficiente $K 3$, que identifica a hora de menor consumo. As curvas de consumo são fundamentais para que sejam feitas previsões de demanda, de curto e longo prazos (HASSEGAWA; ZAHED; IGNÁCIO, 1999).

Com esse intuito, a Sabesp elaborou, em 1999, um estudo detalhado sobre curvas de consumo setoriais, para a RMSP, que tomou por base uma série histórica de três anos e meio de dados de consumo (HASSEGAWA; ZAHED; IGNÁCIO, 1999).

A título de ilustração, são apresentadas, no gráfico contido na Figura 2.17, as curvas de consumo médio, de consumo mínimo e de consumo máximo horário (todos, consumos macromedidos), levantadas pela Sabesp para o Setor Jaçanã - Zona Norte da RMSP.

ANA - Agência Nacional de Águas - Disponível em <http://www.ana.gov.br> e em <http://www.ana.gov.br/Destaque/destaque224.asp> Acesso em 26/05/2007. 


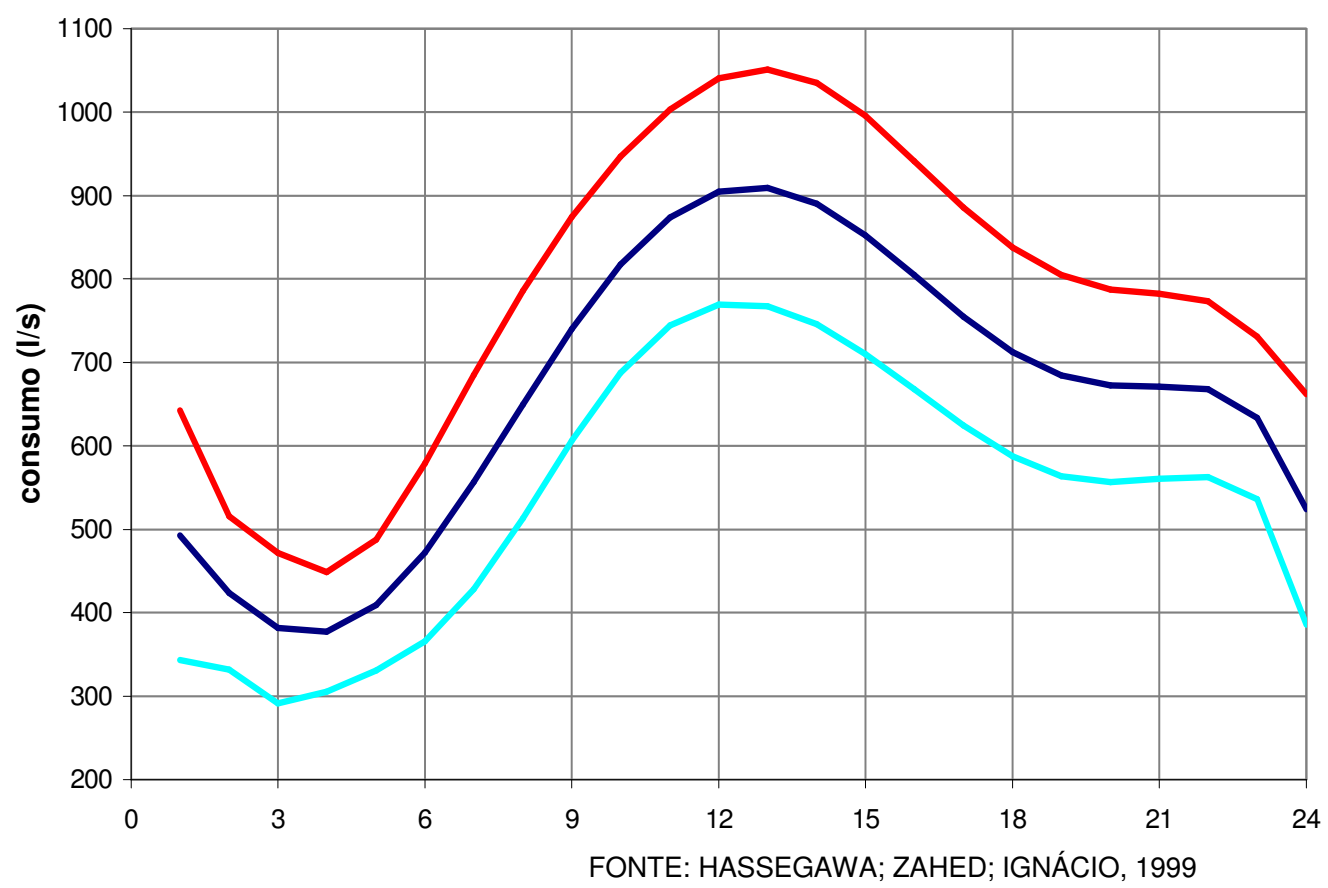

FIGURA 2.17 - Curvas de consumo máximo, médio e mínimo - Setor Jaçanã

\subsection{SISTEMAS DE INFORMAÇÕES GEOGRÁFICAS (SIG)}

São muitas as definições para SIG. Três definições selecionadas são:

Um Sistema de Informação Geográfica (SIG ou GIS - Geographic Information System, do acrónimo inglês) é um sistema de hardware, software, informação espacial e procedimentos computacionais, que permite e facilita a análise, gestão ou representação do espaço e dos fenómenos que nele ocorrem. (pt.wikipedia.org/wiki/GIS)

Geographical Information System ou Sistema de Informação Geográfica: Sistema gráfico para manipulação de desenhos e dados geograficamente referenciáveis. (www.flaviowenzel.hpg.ig.com.br/informatiques/g.html)

Geographic Information System (sistema de informação geográfica) Um sistema de computador para armazenamento, análise e recuperação de informação, no qual toda informação é referenciada espacialmente por suas coordenadas geográficas (norte, leste). Além de dados primários como características climáticas ou de solo, GIS pode ser usado para calcular valores derivados como danos por erosão, áreas florestais e forma de utilização de diferentes tipos de solo.(www.gpsglobal.com.br/Asp/Gloss.asp)

Utilizando, parcialmente, a definição resumida por Silva (1999 apud MARCELLINI, 2002), a partir das diversas definições existentes, os SIGs necessitam, 
sucintamente, de: uso intensivo de informática; uma base de dados georreferenciados integrada; funções de análises de dados.

A página na Internet da Agência para Levantamentos Geológicos do Departamento do Interior do Governo dos Estados Unidos da América - U.S. Geological Survey (USGS) (http://erg.usgs.gov/isb/pubs/gis_poster/) apresenta a seguinte definição para SIG: "Um SIG é um sistema computacional capaz de capturar, armazenar, analisar e apresentar informações geograficamente referenciadas; isto é: dados identificados conforme a sua localização." (tradução nossa)

A mesma página, explica que o poder da ferramenta SIG vem da sua habilidade de relacionar diferentes informações num contexto espacial e de chegar a uma conclusão sobre esse relacionamento. Afirma, ainda, que a maneira como os mapas e outros dados são armazenados no SIG, em camadas ("layers") de informações, torna possível a realização de análises complexas. Cita, por exemplo, que no SIG pode-se apontar para uma determinada localidade, objeto ou área na tela do computador e recuperar as informações armazenadas relacionadas a esse ponto, de arquivos que não estão na tela; e que um SIG pode reconhecer e analisar as relações espaciais entre fenômenos mapeados, como o que está próximo, adjacente ou a que distância de determinado objeto.

Para a pesquisa desenvolvida neste trabalho, foi utilizada a ferramenta SIG, mais precisamente, a ferramenta Signos - Sistema de Informações Geográficas no Saneamento, que é o SIG desenvolvido pela Sabesp para a RMSP. A utilização do Signos foi fundamental na aplicação da metodologia proposta para a pesquisa. Sem a utilização dos recursos proporcionados por essa ferramenta, a pesquisa, nos moldes da metodologia e objetivo propostos, apresentaria um grau de dificuldade muito maior para o levantamento e posterior relacionamento de dados, realizados.

A principal utilização do Signos foi no relacionamento entre as áreas controladas pelas VRPs e áreas testemunha selecionadas e as ligações de água pertencentes a essas áreas, relacionando limites geográficos com o banco de dados do Sistema Comercial, Serviços e Informação (CSI), da Sabesp. Os detalhes da utilização do Signos, na pesquisa em questão, encontram-se explicitados no Capítulo 3 - PROCEDIMENTOS METODOLÓGICOS. 


\section{PROCEDIMENTOS METODOLÓGICOS}

Neste capítulo, são apresentados os passos tomados para levantamento e validação dos dados, utilizados nas análises, bem como os tipos de análises, de totalização e estatística, realizadas.

\subsection{METODOLOGIA}

Neste item, é descrita a metodologia estabelecida para a consecução dos objetivos da pesquisa. São apresentadas as considerações, ao serem adotados filtros, para a obtenção de séries de dados de consumo consistentes, a partir do banco geral de dados levantado.

Para se alcançar o objetivo proposto para a pesquisa, de avaliar a influência da redução de pressão de distribuição de água, devida à instalação de VRP, no consumo registrado nas ligações de água, localizadas dentro dos limites da área com pressão controlada por essas VRPs, foram identificadas as seguintes etapas:

I - Seleção de um conjunto de VRPs e respectivas áreas testemunha.

II - Identificação das ligações de água localizadas dentro dessas áreas.

III - Levantamento dos consumos médios, de cada uma das ligações identificadas, em datas anteriores à implementação da redução de pressão e em datas posteriores a essa implementação.

IV - Análise comparativa das médias de consumo nas ligações identificadas, na situação antes $x$ depois, para se verificar se pode ser confirmada, ou não, variação no nível de consumo médio geral, de cada área de VRP, influenciada pela redução de pressão implementada.

V - Análise comparativa entre a variação de consumo observada nas áreas controladas por VRP e a variação de consumo observada nas suas respectivas áreas testemunha. 
Para a consecução das etapas de pesquisa delineadas, em primeiro lugar, foi solicitada, às áreas responsáveis pela operação de VRPs nas unidades de negócio Centro, Leste e Oeste, da Diretoria Metropolitana, a indicação de cerca de dez VRPs que não tivessem apresentado alterações operacionais ou problemas de manutenção, pelo menos, nos seus dois primeiros anos de funcionamento. Foi colocada, ainda, a restrição da entrada de operação das válvulas indicadas ter sido em data posterior a junho de 2002, uma vez que o Sistema Comercial, Serviços e Informação (CSI), da Sabesp, mantém, no seu banco de dados ativo, dados de sessenta e dois meses móveis, de registro de consumo (volume de dados considerável, levando-se em conta as cerca de três milhões de ligações de água na RMSP). Foi feita exceção apenas à UN Centro, que possui banco de dados complementar, próprio, permitindo a recuperação de dados anteriores àquela data.

Das válvulas indicadas, foram selecionadas, por limitações de número de linhas na Planilha Excel, utilizada para análise dos dados levantados, 27 (vinte e sete) áreas de VRP (17 com controle fixo de saída de pressão e 10 com controle automático de saída), cada uma com suas respectivas áreas testemunha, que totalizaram, antes do tratamento dos dados, cerca de 56.000 ligações.

Para efeito de estudo, as 27 (vinte e sete) áreas de VRP foram nomeadas de F1 a F17, as VRPs com saída fixa de pressão, e de C1 a C10, as VRPs com controle automático de saída de pressão, mesmo índice utilizado para identificar a área testemunha de cada uma delas.

Com a relação de VRPs, foram localizadas, no sistema de informações geográficas da Sabesp (Signos), suas respectivas áreas de controle, sendo selecionadas, com a utilização da ferramenta "trilho" (ou "trace", no equivalente em Inglês), as áreas testemunha (sem influência da redução de pressão de abastecimento provocada pelas VRPs) de cada área de VRP, dando preferência a áreas localizadas nos trechos a montante do ponto de rede de distribuição onde estava instalada cada válvula, ou adjacente à área de VRP, quando havia limitações de espaço devidas à proximidade de outras zonas de pressão. A ferramenta trilho permite a delimitação de uma área (ou polígono), numa planta de rede de distribuição, georreferenciada, levantando-se características referentes a essa área, p.e.: quantidade e identificação de ligações de água; extensão de rede de distribuição; etc. 
No Quadro 3.1, é apresentada a relação de áreas de VRP e respectivas áreas testemunha, selecionadas para o estudo.

Quadro 3.1 - Relação de áreas de VRP e testemunhas, selecionadas para o estudo.

\begin{tabular}{|c|c|c|c|c|c|}
\hline $\mathrm{N}^{0}$ VRP & $\begin{array}{c}\text { ÁREA } \\
\text { TESTEMUNHA }\end{array}$ & $\begin{array}{l}\text { Posição na } \\
\text { RMSP }\end{array}$ & $\mathrm{N}^{\circ}$ VRP & $\begin{array}{c}\text { ÁREA } \\
\text { TESTEMUNHA }\end{array}$ & $\begin{array}{l}\text { Posição na } \\
\text { RMSP }\end{array}$ \\
\hline F1 & $M$ & LESTE & C1 & $M$ & CENTRO \\
\hline F2 & M & LESTE & $\mathrm{C} 2$ & M & CENTRO \\
\hline F3 & $M$ & OESTE & C3 & $M$ & CENTRO \\
\hline $\mathrm{F} 4$ & $M$ & LESTE & $\mathrm{C} 4$ & $M$ & CENTRO \\
\hline F5 & A & CENTRO & C5 & $M$ & LESTE \\
\hline F6 & A & LESTE & C6 & $M$ & LESTE \\
\hline F7 & M & LESTE & $\mathrm{C} 7$ & $M$ & LESTE \\
\hline F8 & $M$ & OESTE & C8 & $M$ & CENTRO \\
\hline F9 & $M$ & OESTE & $\mathrm{C9}$ & $M$ & CENTRO \\
\hline F10 & M & CENTRO & C10 & $M$ & CENTRO \\
\hline F11 & M & LESTE & & & \\
\hline F12 & M & OESTE & onde: & & \\
\hline F13 & M & CENTRO & \multirow{3}{*}{\multicolumn{3}{|c|}{$\begin{array}{l}\text { M: Área a Montante da área controlada } \\
\text { pela VRP. }\end{array}$}} \\
\hline F14 & M & CENTRO & & & \\
\hline F15 & A & LESTE & & & \\
\hline F16 & A & LESTE & \multicolumn{3}{|c|}{ A: Área adjacente à área controlada } \\
\hline $\mathrm{F} 17$ & $M$ & LESTE & & pela VRP. & \\
\hline
\end{tabular}

A seleção de áreas de VRP, no Signos, foi possível por já terem sido carregados, no sistema, os limites georreferenciados das áreas de VRP selecionadas.

A partir da seleção de cada área, foi utilizada a ferramenta de integração do Signos com o CSI, que permitiu a exportação dos dados na forma de Planilha Excel, com a relação das ligações (RGls) localizadas dentro dos limites de cada área.

Nas figuras 3.1, 3.2 e 3.3, são apresentados exemplos de telas do Signos, com diferentes layers, que foram utilizadas na seleção das áreas de VRP e das respectivas áreas testemunha, sendo as imagens dessas figuras relativas à área de VRP F1.

Retomando o encadeamento das etapas, no Signos foram identificados os limites de cada área de VRP. Em seguida, foram ativados os layers de rede de distribuição de água e de zonas de pressão, para, com a utilização da ferramenta trilho, traçar os limites de cada área testemunha. Foi, então, utilizada a ferramenta de integração do Signos com o CSI, levantando a relação de ligações (RGls) localizadas no interior dessas áreas. 
Na Figura 3.1, podem ser observados os limites da área de VRP F1, sem a adição de layers, sendo que, na Figura 3.2, é apresentado o layer de arruamento.

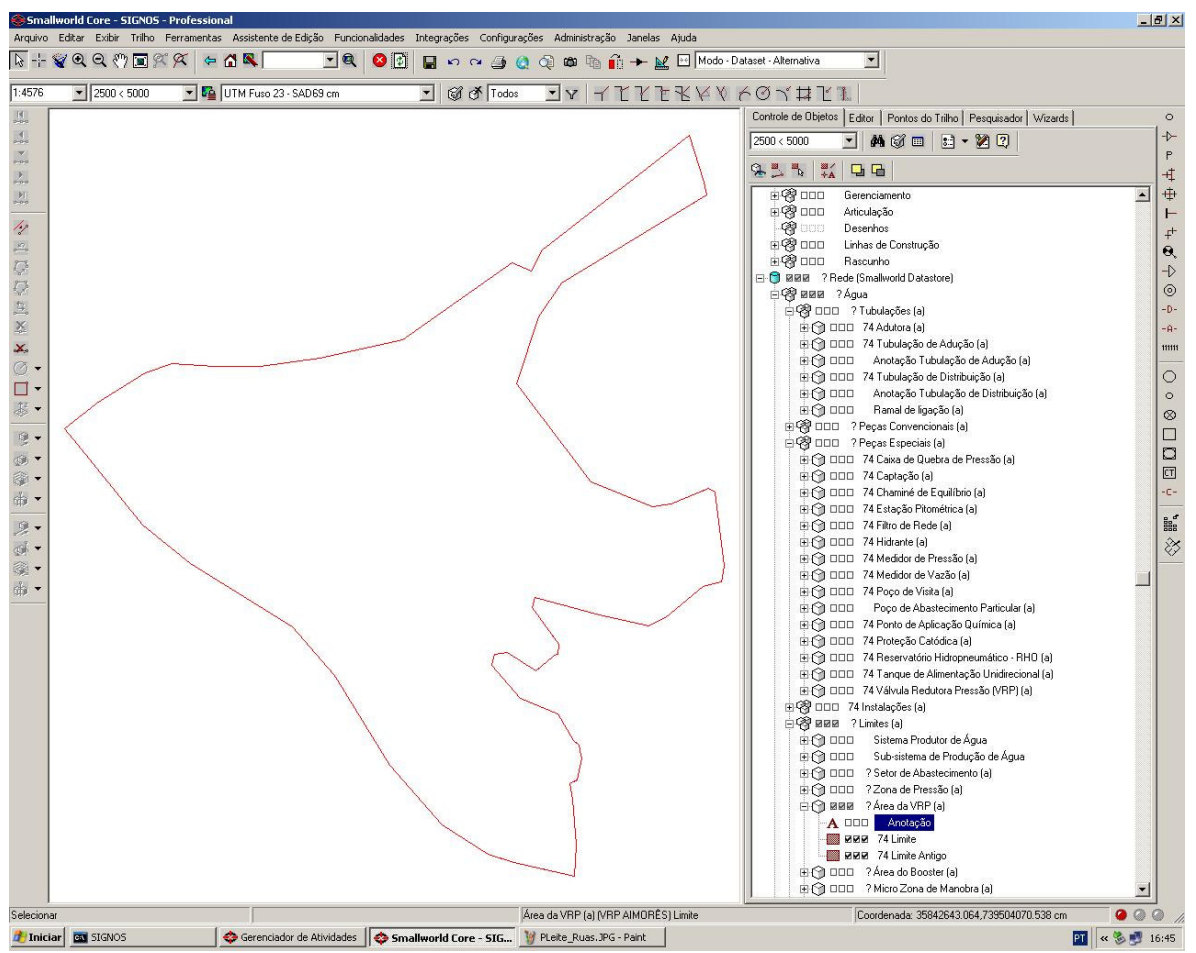

FIGURA 3.1 - Limites da área da VRP F1, sem layers (FONTE: Signos-Sabesp)

(*) figura sem escala; Norte na direção vertical, para cima.

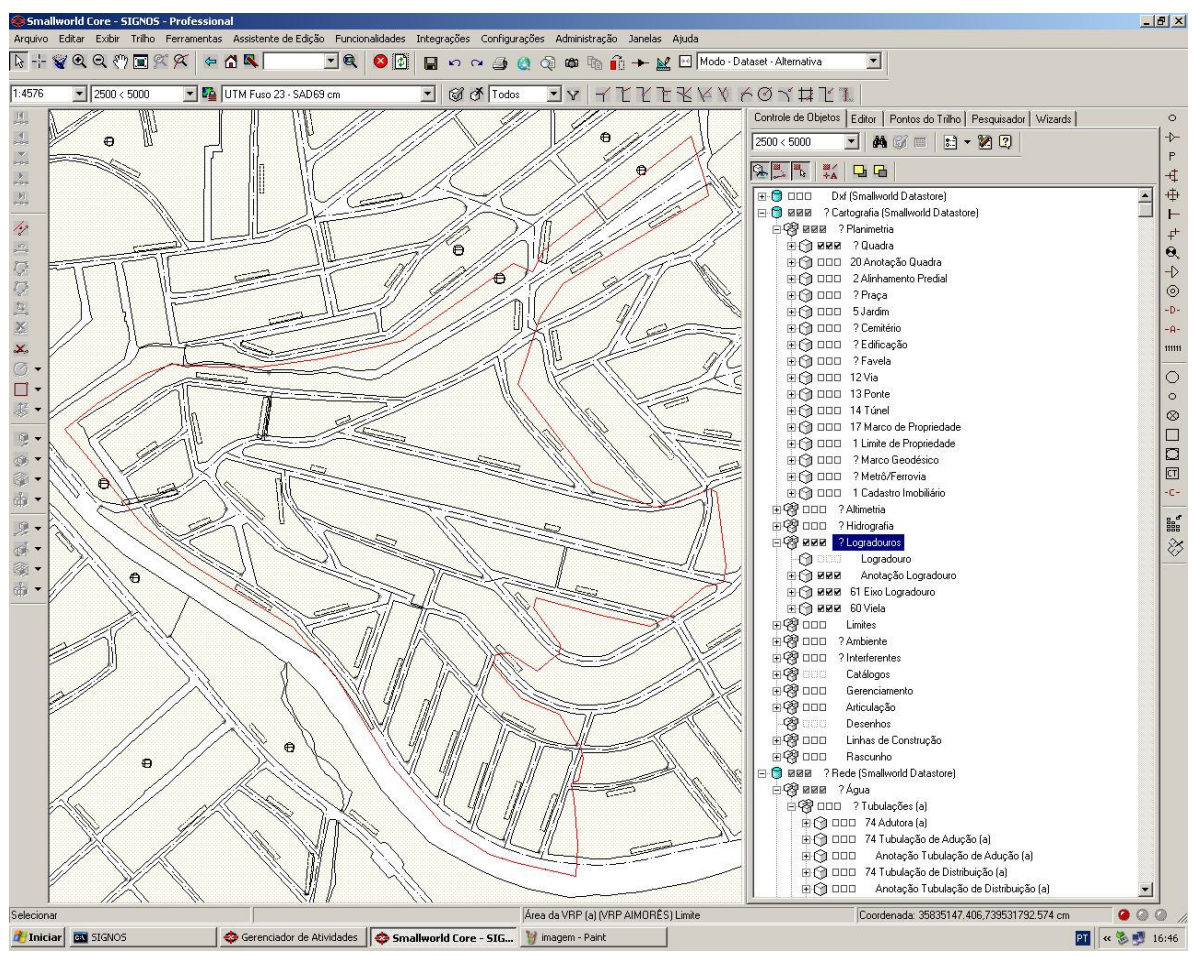

FIGURA 3.2 - Limites da área da VRP F1, com layer de arruamento (FONTE: Signos-Sabesp)

(*) figura sem escala; Norte na direção vertical, para cima. 
Na Figura 3.3, é apresentado o layer de imagem de satélite, onde se pode ter uma idéia do tipo de ocupação na área da VRP F1.

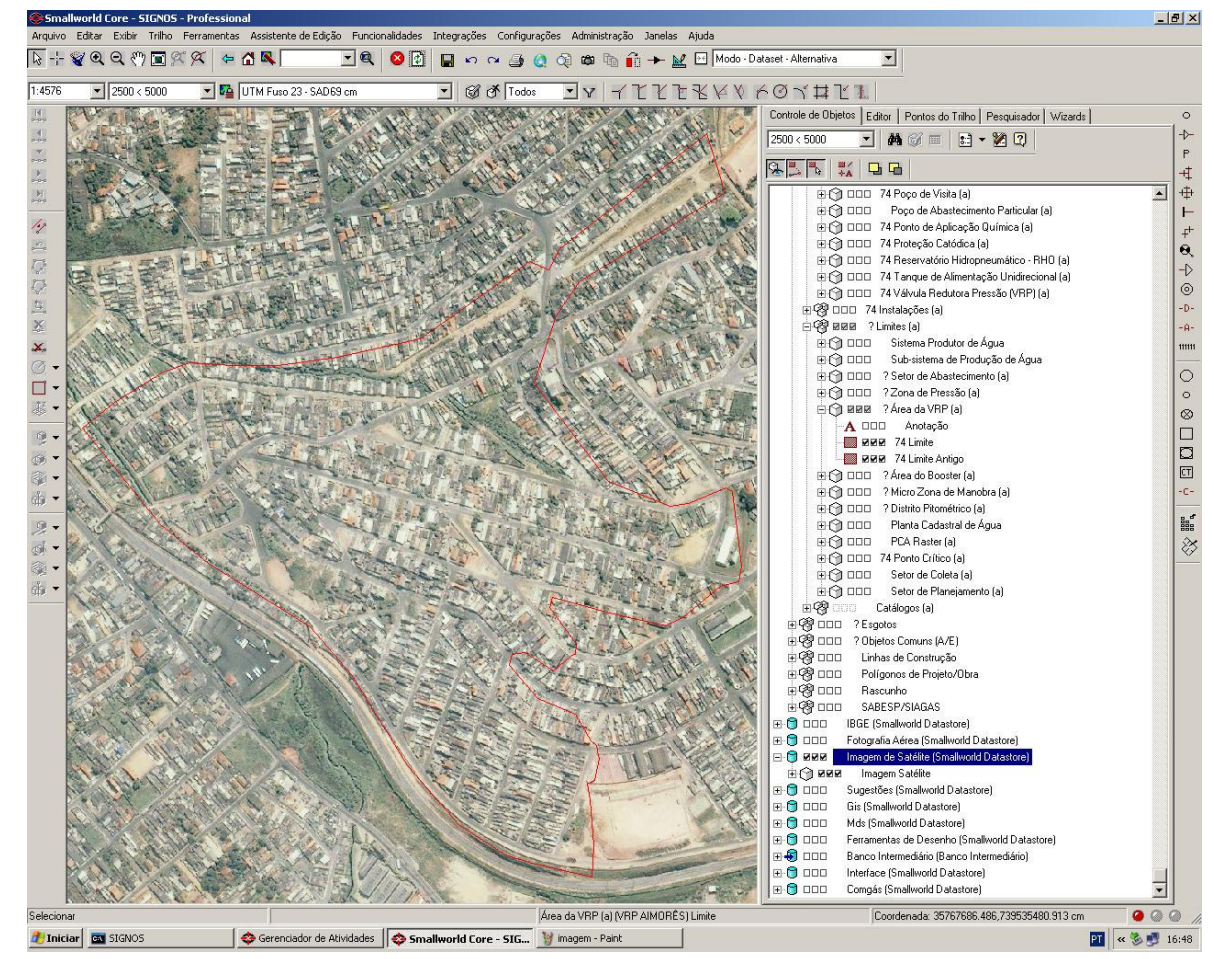

FIGURA 3.3 - Limites da área da VRP F1, com layer de imagem de satélite. (FONTE: SignosSabesp)

(*) figura sem escala; Norte na direção vertical, para cima.

\subsection{REGRAS DE VALIDAÇÃO}

Adicionalmente às condições para garantia da consistência dos dados, estabelecidas no item 3.1, foram estabelecidas regras de validação dos dados de consumo. Esse procedimento visou a minimização de possíveis inconsistências relacionadas a: erros de leitura de medidor; falhas mecânicas nos medidores; ausência de usuários, durante algum(uns) dos períodos de levantamento de consumo; e ausência de consumo.

Para a seleção das ligações, objeto das análises, em cada área de VRP selecionada e em suas respectivas áreas testemunha, foi estabelecido que deveriam ser descartadas as ligações pertencentes a economias industriais e as economias públicas. Num primeiro momento, pensou-se em descartar as economias 
classificadas como comerciais. No entanto, constatou-se que, em diversas das áreas selecionadas, o percentual desse tipo de ligação era considerável e seu descarte poderia acarretar em distorções na avaliação do consumo médio dessas áreas. Dessa forma, optou-se pela manutenção desses dados, em todas as áreas analisadas.

Com a relação dos RGls, agrupados por área, foi feita uma solicitação à área da Sabesp autorizada a pesquisar no banco de dados do CSI, para levantamento dos consumos totais médios mensais, de cada uma das 54 (cinqüenta e quatro) áreas selecionadas (27 áreas de VRP e 27 áreas testemunha), nas datas de referência dos seguintes consumos:

v1: consumo no mês anterior ao mês de entrada em operação de cada VRP;

v2: consumo no mês posterior ao mês de entrada em operação de cada VRP;

v3: consumo no mesmo mês (jan, fev, etc.) do mês anterior à entrada em operação da VRP, no ano seguinte;

v4: consumo no mesmo mês (jan, fev, etc.) do mês posterior à entrada em operação da VRP, no ano seguinte.

M6: média de consumo nos seis meses anteriores à entrada em operação da VRP.

Essas definições dos consumos levantados ficam mais claras fornecendo um exemplo. Supondo-se uma VRP que tenha entrado em operação no mês de abril de 2003: o consumo v1 se refere ao mês de março de 2003; o consumo v2 se refere ao mês de maio de 2003; o consumo v3 se refere ao mês de março de 2004; e o consumo v4 se refere ao mês de maio de 2004.

No trabalho de busca, nos bancos do sistema comercial (CSI), foram excluídas, ainda, as ligações com data de instalação posterior à entrada em operação de cada VRP.

Tomou-se, ainda, a precaução de se eliminar as ligações que não estavam ativas, em qualquer uma das datas de levantamento dos consumos v1, v2, v3 e v4. 
Foi levantado, também, o número de economias (unidade de consumo dos serviços de saneamento) de cada ligação. Em condomínios, por exemplo, uma única ligação abastece várias economias.

Com o banco de dados contendo os consumos de cada ligação (RGI), em cada uma das datas estipuladas e para cada uma das áreas, foram aplicados os seguintes filtros:

a) Foram descartadas as ligações com data de instalação até três meses antes da entrada em operação das VRPs correspondentes (para que se tomassem apenas ligações com um consumo estável), resultando numa redução para um total de 53.921 ligações.

b) Como no levantamento dos consumos médios, nos seis meses anteriores à entrada em operação de cada VRP, não foram descartados possíveis consumos nulos, no cálculo dos consumos médios posteriores (média de v2, v3 e v4), também não foram descartados esses dados de consumo.

c) Como o objetivo da pesquisa é o de avaliar a variação de consumo, antes $x$ depois de um determinado evento, buscou-se manter valores que fossem representativos e eliminar valores de consumo que pudessem ter apresentado algum problema de leitura de consumo ou ausência dos ocupantes da economia. Dessa forma, optou-se pelo descarte de todos os consumos inferiores a $9 \mathrm{~m}^{3} / \mathrm{mês}$ que, considerando-se uma média de três habitantes por economia, numa ligação residencial unifamiliar, equivaleria a um consumo per capita de 100 L/hab/dia, inferior à menor média da RMSP, que é de 110 L/hab/dia. Desse descarte, resultou a redução da base de dados para um total de 31.096 ligações.

d) Para a eliminação de variações bruscas de consumo, numa mesma ligação, o que poderia representar falha no registro de consumo, ausência de moradores, ou mesmo condomínios em fase de ocupação, em um dos períodos de consumo levantados, induzindo a graves erros de avaliação de tendência (o objeto da avaliação é o efeito da redução de pressão de distribuição de água no consumo e não a variação do consumo devida a outros fatores), foi adotado o critério de descarte das ligações cuja relação da diferença do consumo médio nos seis meses anteriores e da média dos consumos posteriores, dividida pela média anterior ou, a mesma diferença, 
dividida pela média posterior, apresentassem valores superiores a 0,6, valor adotado como critério conservador.

Com esse último filtro, resultou um banco de dados de 28.234 ligações, sendo 16.393 internas às áreas de VRP selecionadas e 11.841 ligações pertencentes às áreas testemunha.

As características relativas ao número de ligações e de economias, das áreas de VRP e áreas testemunha selecionadas para a pesquisa, são apresentadas nas figuras 3.4, 3.5 e 3.6 .

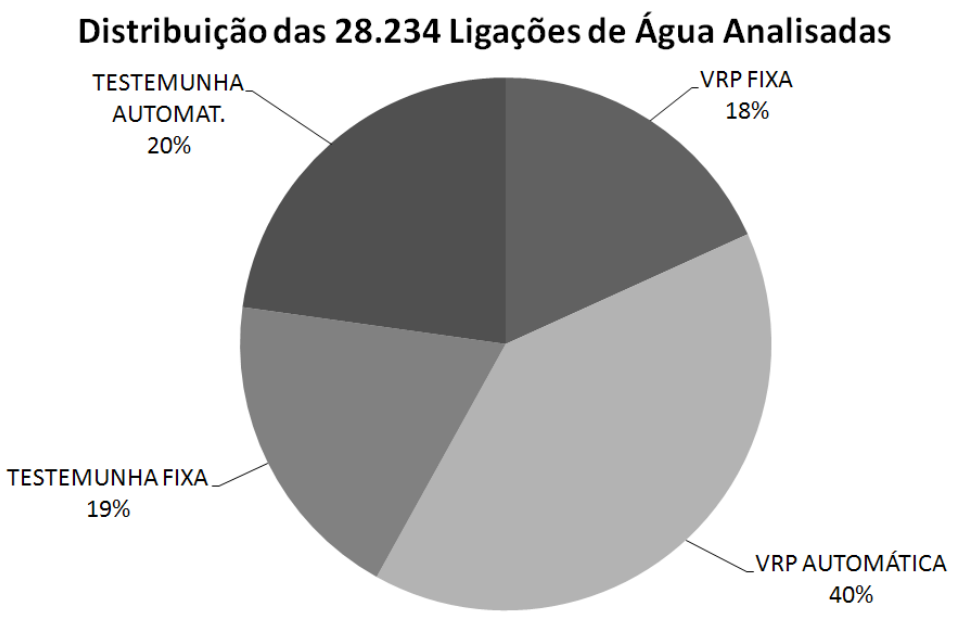

FIGURA 3.4 - Percentual do total de ligações, por tipo de área

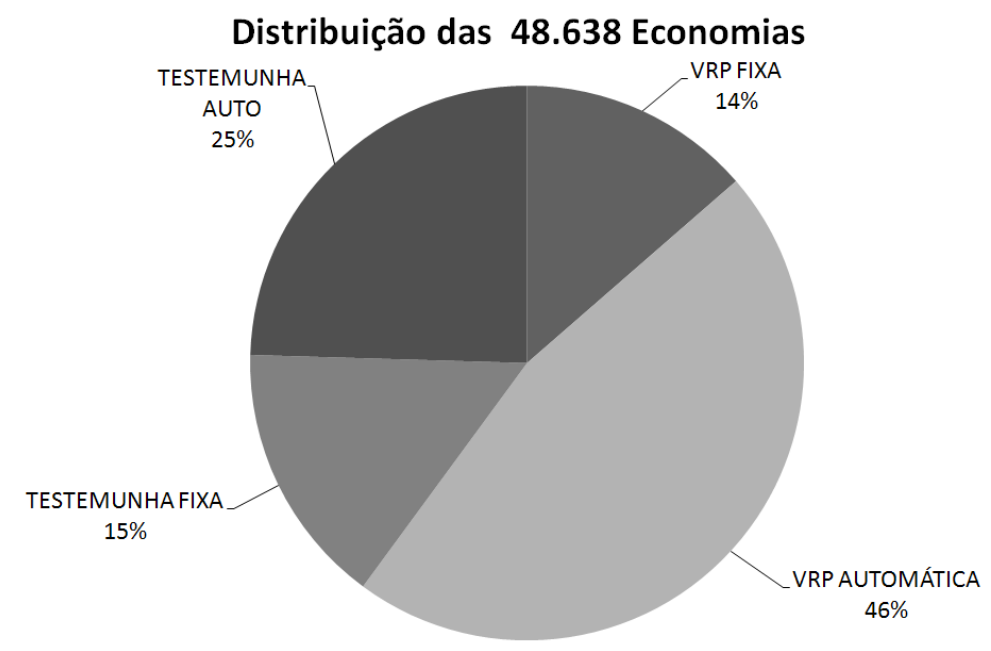

FIGURA 3.5 - Percentual do total de economias, por tipo de área 


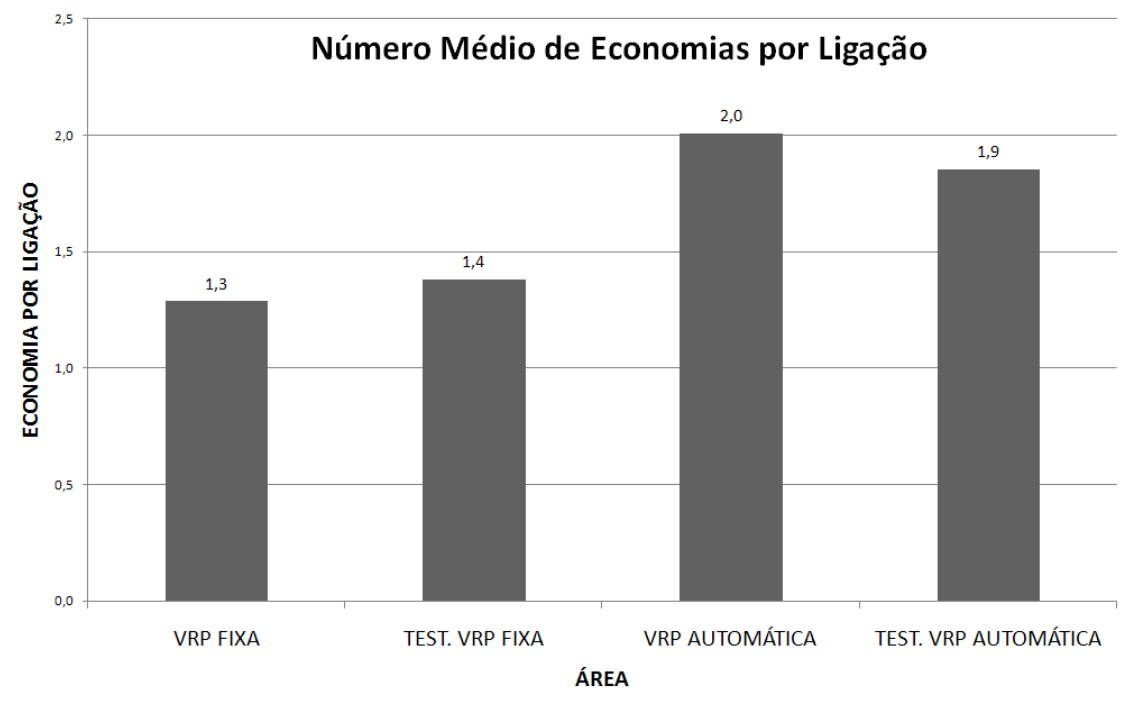

FIGURA 3.6 - Média de economias por ligação, por tipo de área

Nessa configuração, decidiu-se pela análise comparativa entre a média dos seis meses anteriores à implantação da VRP e a média dos consumos nos meses posteriores mencionados.

Visando a eliminação de uma possível tendência de consumo ditada por sazonalidade (meses secos $\mathrm{x}$ meses chuvosos do ano hidrológico) e também a verificação do comportamento geral do consumo, independentemente da instalação de VRPs, foi estabelecida a comparação adicional entre diferença de consumo antes $\mathrm{x}$ depois nas áreas de VRP e a mesma diferença nas áreas testemunha equivalentes.

\subsection{ANÁLISES DE TOTALIZAÇÃO}

Com a base de dados resultante, após a aplicação das regras para minimização de inconsistências, foi estabelecido um conjunto de análises, que é descrito neste item.

Após serem estabelecidas as análises, em primeiro lugar, dos três conjuntos principais de áreas (áreas de VRP + áreas testemunha; áreas de VRP; e áreas testemunha), foi estabelecida uma subdivisão desses conjuntos, buscando maiores detalhes das características da redução de pressão provocada por cada tipo de 
VRP: a) com saída fixa de pressão, onde a pressão permanece constante, independentemente da demanda de consumo na área controlada pela VRP; b) com controle automático de pressão, onde a redução de pressão provocada pela VRP varia de acordo com a demanda de consumo na área controlada pela VRP.

Como para cada área controlada por VRP (seja com saída fixa de pressão ou com controle automático) foi selecionada uma área testemunha que não sofre influência da redução de pressão, foi adotada a mesma subdivisão para essas áreas, para que possa ser feita uma comparação entre os comportamentos de consumo médio das ligações dessas áreas com os comportamentos de consumo médio das correspondentes áreas controladas por VRP, eliminando algum vício de sazonalidade que possa estar contido nos dados de consumo levantados.

Aprofundando o nível de investigação, ao se avaliar o número de ligações de água com múltiplas economias, aventou-se a possibilidade desse conjunto de ligações ter uma participação significativa no consumo total dos diversos conjuntos de áreas. Esse tipo de ligação, representado por condomínios verticais e horizontais, poderia apresentar um comportamento diferente do conjunto formado pelas ligações de pequena capacidade, dadas as grandes diferenças de perfil de consumo e de dimensões de hidrômetros e de reservatórios.

Dessa forma, as análises foram estratificadas em mais três subconjuntos, conforme o número máximo de economias abastecidas por cada ligação: 1) até 12 economias por ligação; 2) até 3 economias por ligação; e 3) uma única economia por ligação.

Assim, para se verificar se a redução de pressão de distribuição de água, implementada nas áreas de VRP, influenciou, ou não, o consumo médio das ligações localizadas nessas áreas de influência, e frente ao que foi ponderado no item 3.2 REGRAS DE VALIDAÇÃO, foi estabelecida a elaboração de sete grupos de análise, representando um total de 19 análises, relacionadas no Quadro 3.2. 
Quadro 3.2 - Análises dos dados de consumo médio total das ligações

Análise 1 Médias de consumos em todas as áreas (de VRP + testemunha): avaliação da tendência média geral de variação no consumo médio (antes $x$ depois) do conjunto formado pelas 54 áreas (27 controladas por VRP e 27 testemunhas) selecionadas para a pesquisa.

Análise 2 Médias de consumos nas áreas de VRP: avaliação da tendência de variação no consumo médio (antes $x$ depois) do conjunto de áreas controladas por VRP.

Análise 3 Médias de consumos nas áreas testemunha: avaliação da tendência de variação no consumo médio (antes $x$ depois) do conjunto de áreas testemunha de áreas controladas por VRP.

Análise 4 Médias de consumos nas áreas de VRP com saída fixa: avaliação da tendência de variação no consumo médio (antes $x$ depois) do conjunto de áreas controladas por VRP com saída fixa de pressão.

Análise 4.1 VRP FIXA (até 12 economias por ligação): a mesma que a Análise 4, aplicada ao conjunto de ligações com até 12 economias por ligação.

Análise 4.2 VRP FIXA (até 3 economias por ligação): a mesma que a Análise 4, aplicada ao conjunto de ligações com até três economias por ligação.

Análise 4.3 VRP FIXA (1 economia por ligação): a mesma que a Análise 4, aplicada ao conjunto de ligações com apenas uma economia por ligação.

Análise 5 Médias de consumos nas áreas de VRP com controle automático de saída: avaliação da tendência de variação no consumo médio (antes $x$ depois) do conjunto de áreas controladas por VRP com controle automático de saída de pressão.

Análise 5.1 VRP AUTOMÁTICA (até 12 economias por ligação): a mesma que a Análise 5, aplicada ao conjunto de ligações com até 12 economias por ligação.

Análise 5.2 VRP AUTOMÁTICA (até 3 economias por ligação): a mesma que a Análise 5, aplicada ao conjunto de ligações com até três economias por ligação.

Análise 5.3 VRP AUTOMÁTICA (1 economia por ligação): a mesma que a Análise 5, aplicada ao conjunto de ligações com apenas uma economia por ligação.

Análise 6 Médias de consumos nas áreas testemunha de VRP com saída fixa: avaliação da tendência de variação no consumo médio (antes $x$ depois) do conjunto de áreas testemunha de VRP com saída fixa de pressão.

Análise 6.1 Área Testemunha FIXA (até 12 economias por ligação): a mesma que a Análise 6, aplicada ao conjunto de ligações com até 12 economias por ligação.

Análise 6.2 Área Testemunha FIXA (até 3 economias por ligação): a mesma que a Análise 6 , aplicada ao conjunto de ligações com até três economias por ligação.

Análise 6.3 Área Testemunha FIXA (1 economia por ligação): a mesma que a Análise 6 , aplicada ao conjunto de ligações com apenas uma economia por ligação. 
(continuação)

Análise 7 Médias de consumos nas áreas testemunha de VRP com saída automática: avaliação da tendência de variação no consumo médio (antes $x$ depois) do conjunto de áreas testemunha de VRP com controle automático de saída de pressão.

Análise 7.1 Área Testemunha AUTOMÁTICA (até 12 economias por ligação): a mesma que a Análise 7, aplicada ao conjunto de ligações com até 12 economias por ligação.

Análise 7.2 Área Testemunha AUTOMÁTICA (até 3 economias por ligação): a mesma que a Análise 7 , aplicada ao conjunto de ligações com até três economias por ligação.

Análise 7.3 Área Testemunha AUTOMÁTICA (1 economia por ligação): a mesma que a Análise 7, aplicada ao conjunto de ligações com apenas uma economia por ligação.

Para a preparação das séries de dados, para as diversas análises, foi utilizada a ferramenta Tabela Dinâmica, da Planilha Excel, sobre cada um dos bancos de dados, filtrados conforme estabelecido nas regras de validação (item 3.2).

Dessa forma, foram geradas 19 tabelas dinâmicas, onde os dados foram agrupados por área (de VRP e/ou testemunha), sendo totalizados os número de ligações e de economias, bem como calculados os consumos médios totais de cada uma das áreas, para cada um dos casos analisados: totalização de número de ligações, número de economias, médias de v1, v2, v3, v4, consumo médio nos seis meses anteriores e média nos meses posteriores (v2, v3 e v4), para cada uma das áreas em estudo, feitas com a utilização da ferramenta.

De cada uma das tabelas dinâmicas, foram anotados os consumos médios, de cada área, em cada situação, nos momentos: antes da entrada em operação da VRP (consumo médio nos seis meses anteriores), indicada pela variável Xi (em m³/ligação/mês), e após a entrada em operação da VRP (média dos consumos posteriores v2, v3 e v4), indicada pela variável Yi (em m³/ligação/mês).

As séries foram geradas, para cada uma das 19 análises propostas, pelo cálculo da diferença dessas duas médias, média antes menos média depois: $\mathrm{Di}=\mathrm{Xi}-\mathrm{Yi}$.

Nos gráficos apresentados nas figuras 3.7, 3.8 e 3.9, pode-se visualizar o comportamento do consumo médio nas situações, antes $\mathrm{x}$ depois, nas áreas com 
pressão controlada por VRP e nas áreas testemunha (sem influência da redução de pressão).

No gráfico representado na Figura 3.7, pode ser observada uma leve redução no consumo em dezesseis das vinte e sete áreas controladas por VRP selecionadas para a pesquisa.

Destacam-se dos demais consumos, os consumos das áreas C1, C8 e C10, que, provavelmente, se devem ao alto índice de verticalização dessas áreas.

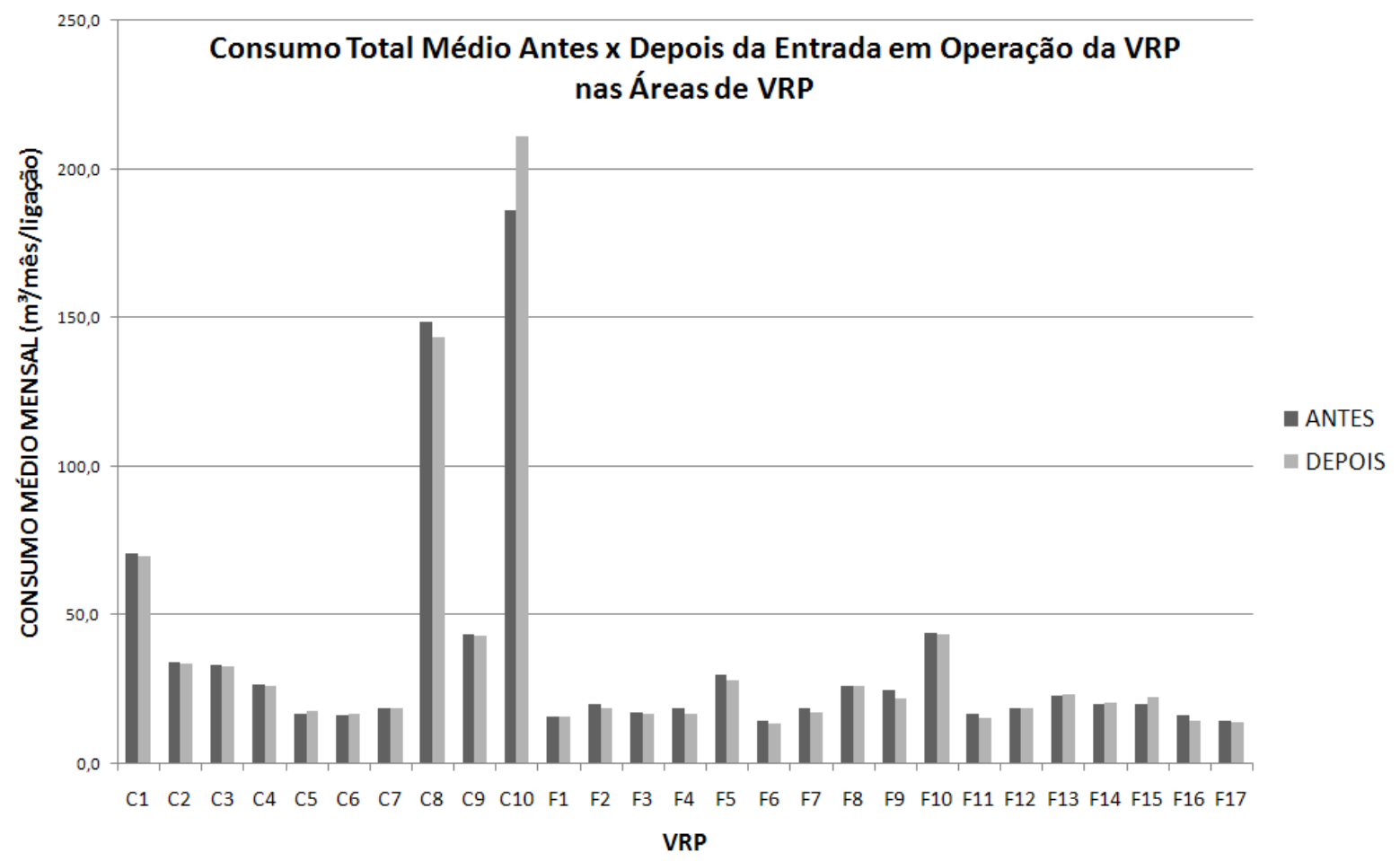

FIGURA 3.7 - Consumo médio total, antes $x$ depois da redução de pressão implementada, nas áreas controladas por VRP, selecionadas 
No gráfico da Figura 3.8, quando se faz o mesmo tipo de análise, nas áreas testemunha (sem influência da redução de pressão), pode-se visualizar que dezessete das vinte e sete áreas, apresentam a mesma tendência de redução no consumo.

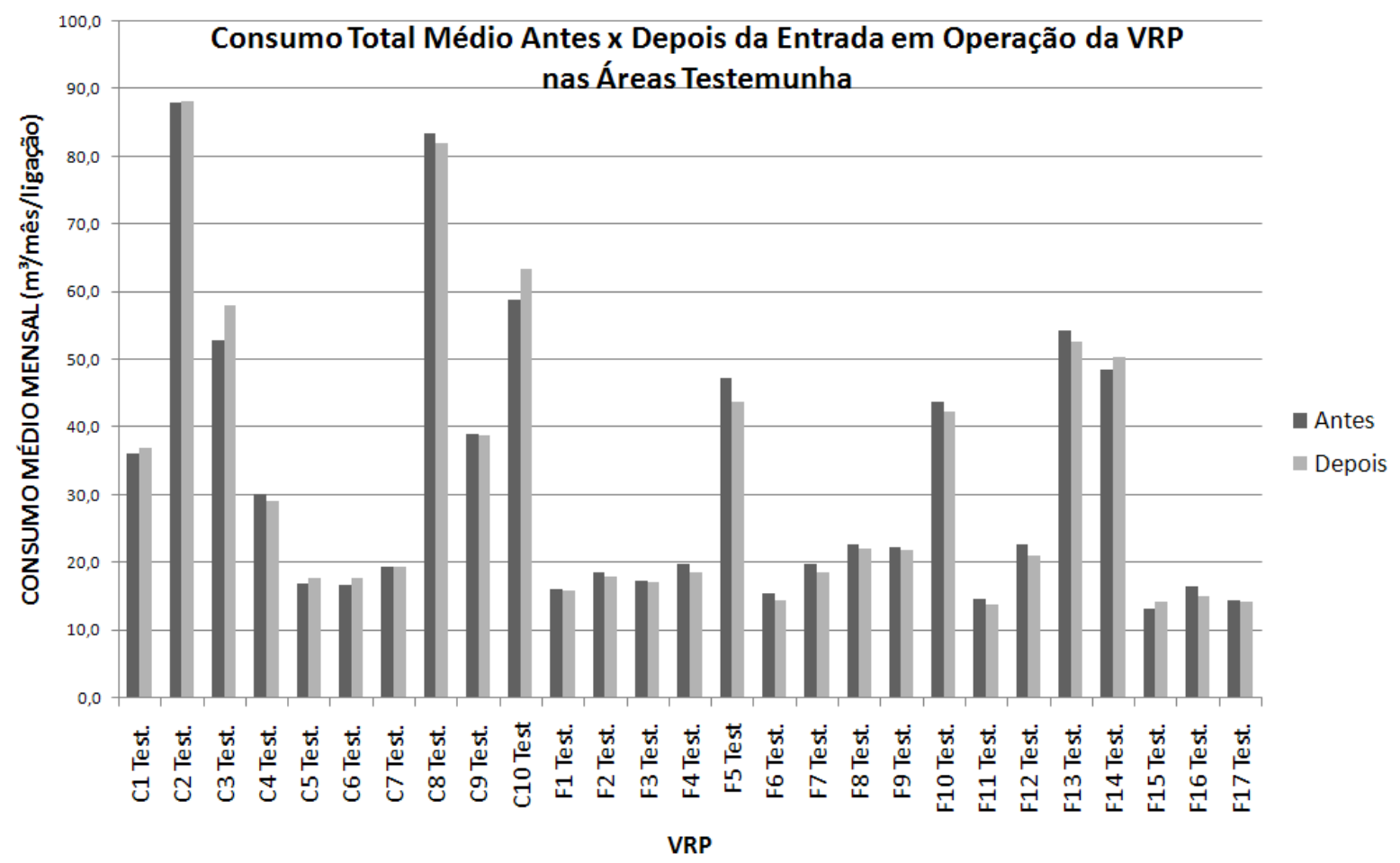

FIGURA 3.8 - Consumo médio total, antes $x$ depois da redução de pressão implementada, nas áreas testemunha de áreas controladas por VRP

No gráfico da Figura 3.9, são apresentadas as diferenças entre os consumos (antes-depois), tanto para as áreas controladas por VRP, quanto para suas respectivas áreas testemunha. Nesse gráfico, pode-se visualizar que a tendência da maioria das áreas foi a de uma leve redução no consumo (diferença, entre o consumo antes e o consumo depois, positiva). 


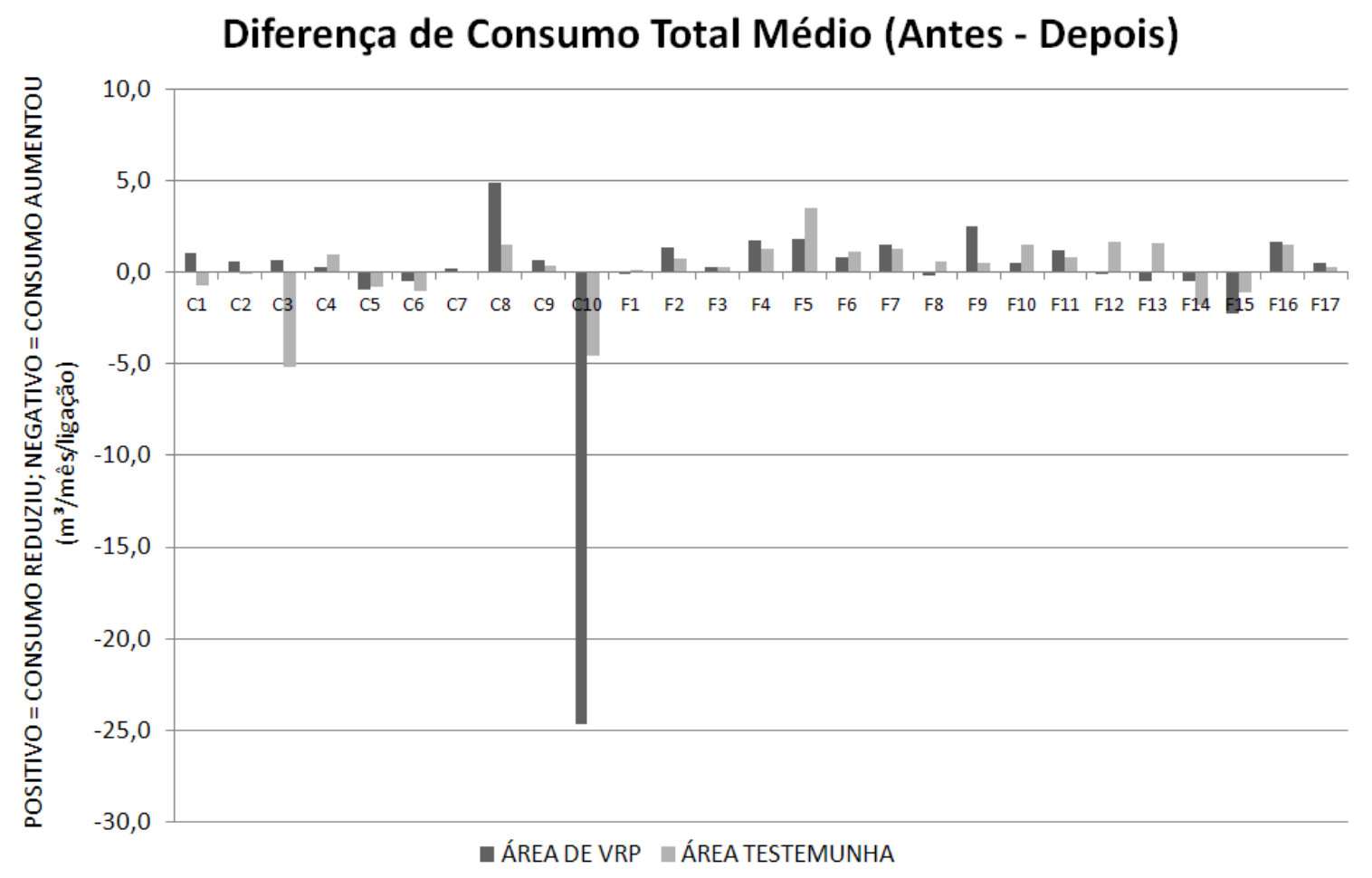

FIGURA 3.9 - Comparação das diferenças de consumo (antes - depois), entre as áreas de VRP e as áreas testemunha

Com as análises apresentadas até este ponto, sem a elaboração de análises estatísticas de significância, não é possível afirmar, com confiança, se houve, ou não variação no consumo. O que se pode afirmar, pela análise visual dos gráficos apresentados, é que pode haver dados extremos que tendem a distorcer os resultados das séries de dados em análise e que são necessárias análises de consistência, antes da realização dos testes de significância.

\subsection{ANÁLISES ESTATÍSTICAS}

Com base nos conjuntos de análises estabelecidos no item 3.3, foram feitas análises de consistência estatística, no sentido de se filtrarem dados uniformes para a pesquisa, utilizando-se a técnica conhecida por box plot, e testes de significância, através da realização de testes de hipóteses, conhecidos por testes de t-pareado, indicados para a comparação da mesma amostra na situação antes e depois. 
Antes da realização das análises estatísticas para a verificação da ocorrência, ou não, de tendências no padrão de consumo das ligações em pauta, foram efetuados, primeiramente, testes para a verificação da consistência dos dados.

Optou-se pela realização dos testes de box plot, desenvolvidos, em 1977, pelo estatístico americano John Tukey, que se constituem numa maneira padronizada de se apresentar a distribuição de uma série de dados e de identificação de pontos extremos, que possam distorcer as características dessa série, chamados de outliers e possíveis outliers. A página de estatística da College of Saint Benedict and Saint John's University - Minnesota/USA reproduz a definição precisa que John Tukey propôs para dois tipos de outliers:

- "Outliers são tanto os valores [localizados a] $3 \times \| \mathrm{IQ}$ [intervalo interquartil], ou mais, acima do terceiro quartil, ou $3 \times \| Q$, ou mais, abaixo do primeiro quartil;

- Possíveis outliers são versões ligeiramente mais centrais de outliers: tanto $1,5 \times \| Q$, ou mais, acima do terceiro quartil, ou $1.5 \| Q$,ou mais, abaixo do primeiro quartil." (CSB/SJU, 2007)

A proposta dos box plot é a de uniformização dos critérios para consistência de séries de dados e para identificação de valores inconsistentes com o restante da série (outliers).

No modelo de box plot, adotado para as análises das séries de dados da pesquisa, os limites propostos por Tukey, à distância de 1,5 IQQ, acima do terceiro quartil e abaixo do primeiro quartil, foram chamados de grade interna superior e inferior, respectivamente, e os limites à distância de 3,0 IIQ acima do terceiro quartil e abaixo do primeiro quartil, foram chamados de grade externa superior e inferior, respectivamente, sendo que o intervalo interquartil (IIQ) é calculado pela diferença entre o terceiro quartil e o primeiro quartil.

$\mathrm{Na}$ Figura 3.10, é apresentada uma representação de gráfico de box plot, para melhor compreensão do modelo utilizado, em que, mesmo os pontos que caíram na faixa entre as grades internas e as externas, foram considerados outiliers. 


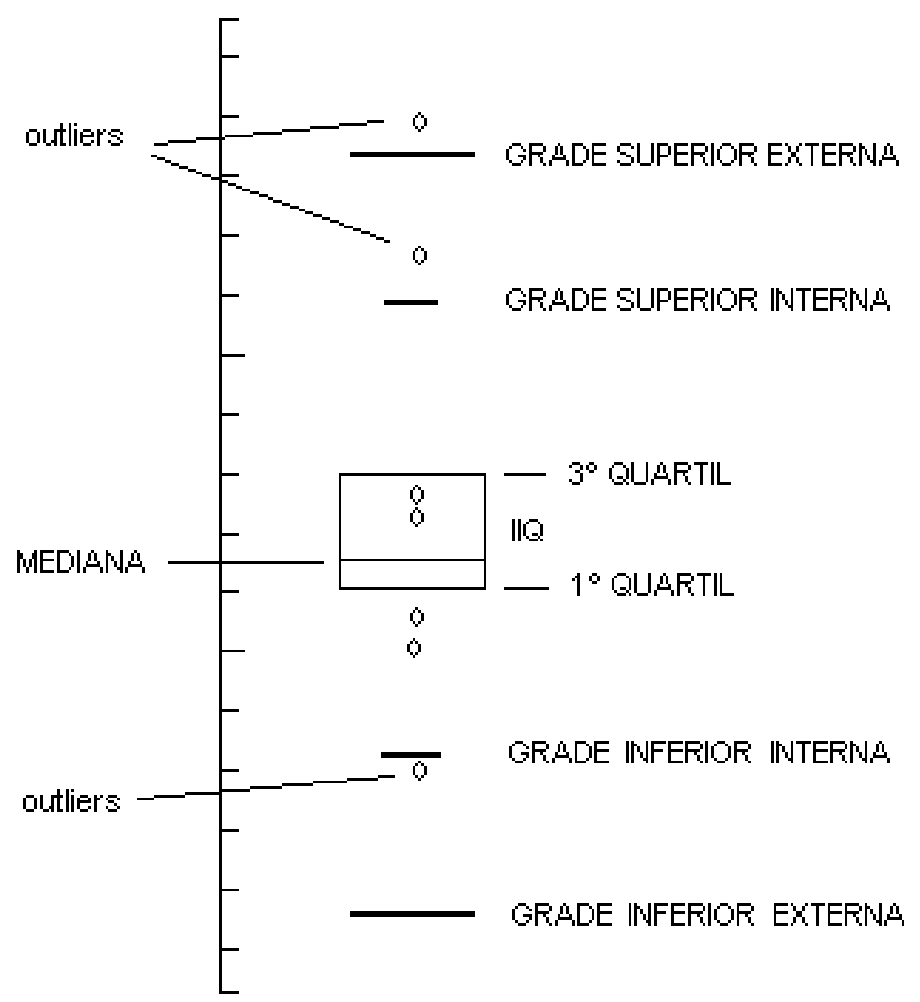

FIGURA 3.10 - Exemplo de gráfico de box plot, com grades

Na Figura 3.11, são apresentadas as séries de dados de diferença de consumo, para os principais grupos de áreas, contemplados nas análises, na forma de gráfico de box plot. Como o objetivo do gráfico, nessa figura, é o de fornecer uma visualização da distribuição das séries de dados, não foi utilizado o modelo de box plot com grades.

Nessa figura pode-se observar que alguns dados de diferença de consumo, de algumas das séries, apresentam um descolamento muito grande do restante dos dados da série.

Por esse motivo, foram realizados testes, adicionais, de box plot com grades, buscando a identificação dos dados que poderiam provocar distorções nos resultados

Após a identificação dos outiliers, para a série de dados a ser utilizada em cada uma das análises propostas, decidiu-se pelo descarte dos valores identificados como outiliers, uma vez que o objetivo da pesquisa é o de identificar um padrão de comportamento e não comportamentos fora do padrão. 


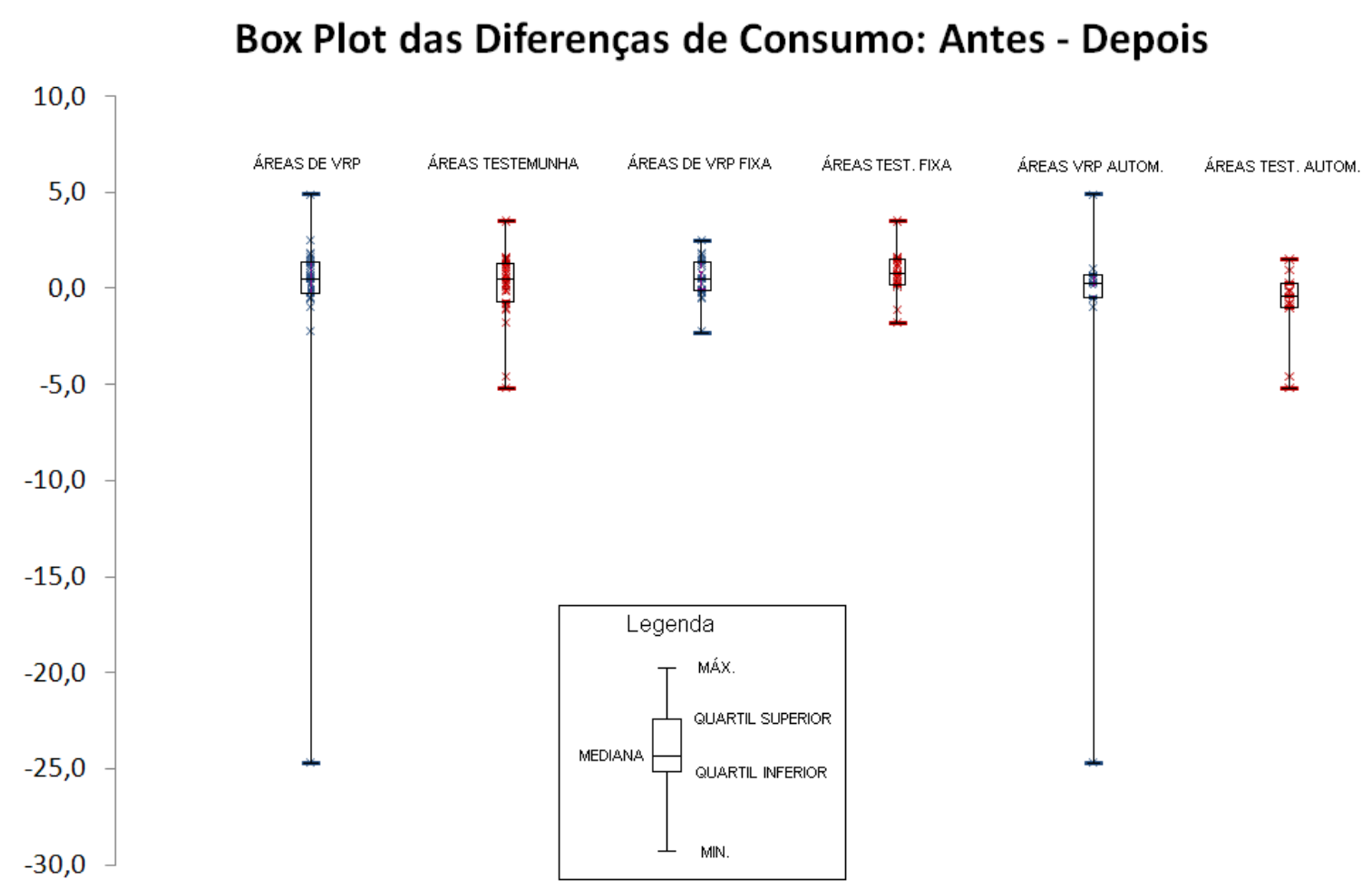

FIGURA 3.11 - Apresentação das séries de dados de diferenças de consumo - box plot

Para se avaliar se em cada um dos casos propostos nas análises estabelecidas houve, ou não, variação no padrão de consumo, decidiu-se pela utilização de testes paramétricos de hipóteses, para comparação de duas médias.

Com base na literatura pesquisada, o teste que melhor se ajustou às características do caso da pesquisa em questão foi o teste de hipóteses de diferenças entre médias populacionais, para dados pareados (também conhecidos por "testes de t-pareado"): comparação de dados da mesma população, nas situações antes e depois.

Por se utilizar de diferenças entre médias, esse tipo de teste tem a vantagem adicional de eliminar distorções de ordem de grandeza, passíveis de ocorrerem no caso em estudo, devidas às possíveis diferenças de dimensões entre as diversas áreas e à possibilidade de concentração de grandes consumidores em alguma(s) das áreas. 
Da página do LEG - UFPR ${ }^{1}$, na Internet, foi levantada a seguinte definição: chamase "hipótese estatística qualquer afirmação que se faça sobre um parâmetro populacional desconhecido. [...] a partir de uma amostra da população pode-se estabelecer uma regra de decisão segundo a qual se rejeita ou se aceita a hipótese proposta [...]. Normalmente existe uma hipótese que é mais importante para o pesquisador que será denotada por $\mathrm{H}_{0}$ e chamada hipótese nula. Qualquer outra hipótese diferente de $\mathrm{H}_{0}$ será chamada de hipótese alternativa e denotada por $\mathrm{H}_{1}$ ".

Os passos para execução do teste de hipóteses (t-pareado), considerando-se uma distribuição de Student bi-caudal, uma vez que o que se está comparando é se o consumo variou, para mais, ou para menos, se consistem em: 1) cálculo da média e desvio padrão da série de dados; 2) escolha de um nível de significância

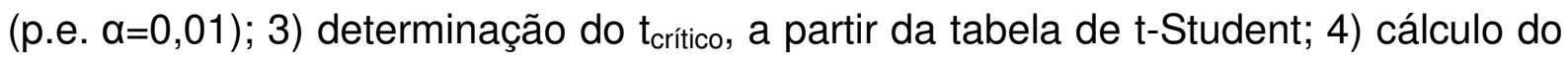
$t_{\text {observado }}$ da série de dados; 5 ) comparação do $t_{\text {observado }}$ com o $t_{\text {crítico }}$ para verificar se 0 $t_{\text {observado }}$ se encontra dentro ou fora do intervalo de confiança (IC), região de aceitação da hipótese nula (IC varia de - $t_{\text {crítico }} a+t_{\text {critico }}$ ); e 6) conclusão: se $t_{\text {observado }}$ estiver dentro da região de aceitação (intervalo de confiança), se aceita a hipótese nula $\left(\mathrm{H}_{0}\right)$ e se tobservado estiver fora da região de aceitação, rejeita-se a hipótese nula $\left(H_{0}\right)$. A Figura 3.12 ilustra, graficamente, esse tipo de teste.

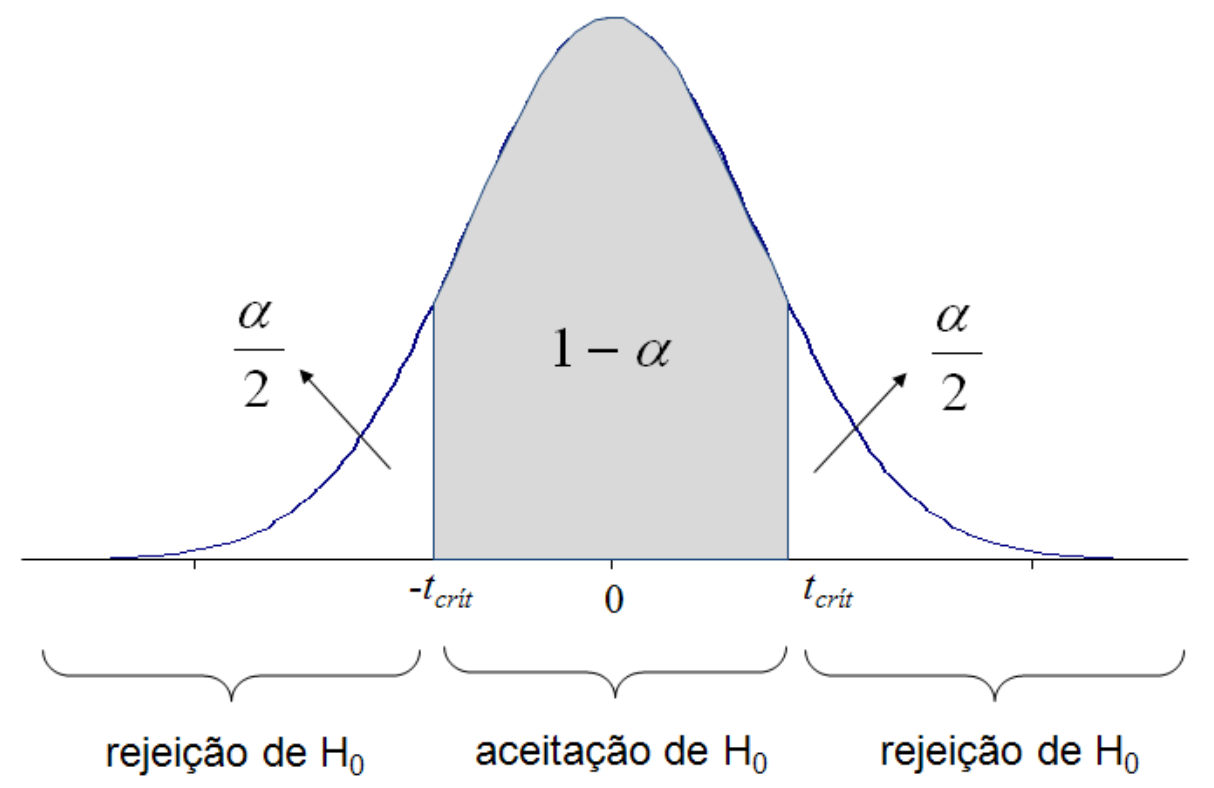

FIGURA 3.12 - Representação gráfica de teste de hipóteses

\footnotetext{
${ }^{1}$ LEG-Laboratório de Estatística e Geoinformação da Universidade Federal do Paraná. Disponível em < http://leg.ufpr.br/ paulojus/CE210/ce210/node3.html\#SECTION00310000000000000000> Acesso em 27/05/2007.
} 
Para os testes de hipóteses realizados nesta pesquisa, foi estabelecida a Hipótese Nula - $\mathrm{H}_{0}$ : a média das diferenças entre o consumo médio antes da entrada em operação da VRP e o consumo médio após a entrada em operação da VRP é igual a zero (o consumo não variou). E, conseqüentemente, a Hipótese Alternativa $\mathrm{H}_{1}$ : a média das diferenças entre o consumo médio antes da entrada em operação da VRP e o consumo médio após a entrada em operação da VRP é diferente de zero (o consumo variou).

Nos testes de significância, ou testes de hipóteses, a chamada "hipótese nula", contra a qual se busca evidências de ser, ou não, verdadeira, foi sempre a mesma: a diferença entre as médias de consumo, antes e após a entrada em operação da VRP, é nula. Ou seja, se a hipótese nula for aceita como verdadeira, o consumo não variou.

Nesse tipo de teste, dois resultados são possíveis: a) rejeita-se a hipótese nula, significando que existem boas evidências estatísticas de que o consumo variou; e b) não se pode rejeitar a hipótese nula, o que não significa que o consumo não variou mas, apenas, que não existem boas evidências estatísticas para se afirmar que houve variação no consumo.

Convém ressaltar que, nos casos em que os resultados dos testes de hipóteses mostraram que a hipótese nula foi rejeitada e que houve variação (aumento ou redução) na média de consumo geral das ligações de um determinado conjunto de áreas, essa informação, por si só, não representa nenhum comportamento influenciado pela redução de pressão provocada pela instalação de VRP, uma vez que existe a possibilidade de uma tendência geral, na região onde se localizam essas áreas, de redução no consumo. Para a confirmação dessas tendências, é necessária a comparação entre áreas controladas por VRP e as áreas testemunha correspondentes.

As planilhas com a totalização dos consumos médios, de cada uma das áreas avaliadas nas análises, com cálculos dos testes de consistência (box plot) e com os testes paramétricos de hipóteses, encontram-se nos apêndices A, B, C e D.

Na seqüência, é apresentado, como exemplo, no Quadro 3.3 e na Figura 3.13, o teste utilizado para verificação da consistência dos dados, através do uso de box 
plot, no caso da série de dados de diferença de consumo para as áreas de VRP com saída fixa de pressão. Em seguida, é apresentado no Quadro 3.4, também como exemplo, o teste de hipóteses realizado para se avaliar se houve, ou não, variação no nível de consumo, no mesmo caso de áreas de VRP com saída fixa de pressão. 


\title{
Quadro 3.3 - Exemplo de planilha de cálculo de box plot
}

\author{
ANÁLISE 2: ÁREAS DE VRP \\ BOX-PLOT COM CERCAS, DOS VALORES DE CONSUMO MÉDIO NAS ÁREAS DE VRP, PARA IDENTIFICAÇÃO \\ DE OUTLIERS
}

\begin{tabular}{|c|c|c|c|c|c|c|c|c|c|}
\hline & VRP & ANTES (Xi) & APÓS (Yi) & $\mathrm{Di}=(\mathrm{Xi}-\mathrm{Yi})$ & & \multirow{6}{*}{$\begin{array}{l}\text { MÉDIA: } \\
\text { AMPLITUDE: } \\
\text { N CLASSES: } \\
\text { FAIXA: }\end{array}$} & \multicolumn{2}{|c|}{$-0,3$} & \\
\hline 1 & $\mathrm{C} 10$ & 186,4 & 211,1 & $-24,7$ & & & \multicolumn{2}{|c|}{29,6} & \\
\hline 2 & F15 & 20,1 & 22,3 & $-2,3$ & & & \multirow{2}{*}{\multicolumn{2}{|c|}{$\begin{array}{r}5 \\
58 \sim 60\end{array}$}} & \\
\hline 3 & $\mathrm{C} 5$ & 16,8 & 17,8 & $-1,0$ & & & & & \\
\hline 4 & $\mathrm{~F} 13$ & 22,9 & 23,4 & $-0,5$ & & & & & \\
\hline 5 & C6 & 16,3 & 16,9 & $-0,5$ & & & & & \\
\hline 6 & F14 & 20,3 & 20,8 & $-0,5$ & Classe & Consumo & ni & fi & fac \\
\hline 7 & F8 & 26,1 & 26,3 & $-0,2$ & 1 & $-25,0$ a $-19,0$ & 1 & 0,04 & 0,04 \\
\hline 8 & $\mathrm{~F} 12$ & 18,8 & 18,9 & $-0,1$ & 2 & $-19,0$ a $-13,0$ & 0 & 0,00 & 0,04 \\
\hline 9 & $\mathrm{~F} 1$ & 15,8 & 16,0 & $-0,1$ & 3 & $-13,0 a-7,0$ & 0 & 0,00 & 0,04 \\
\hline 10 & $\mathrm{C} 7$ & 18,8 & 18,7 & 0,2 & 4 & $-7,0$ a $-1,0$ & 1 & 0,04 & 0,07 \\
\hline 11 & $\mathrm{~F} 3$ & 17,3 & 17,0 & 0,2 & 5 & $-1,0$ a 5,0 & 25 & 0,93 & 1,00 \\
\hline 12 & $\mathrm{C} 4$ & 26,7 & 26,4 & 0,3 & & soma $=$ & 27 & & \\
\hline
\end{tabular}

\begin{tabular}{|c|c|c|c|c|}
\hline 13 & F10 & 43,9 & 43,4 & 0,5 \\
\hline 14 & F17 & 14,7 & 14,2 & 0,5 \\
\hline 15 & C2 & 34,1 & 33,5 & 0,5 \\
\hline 16 & C3 & 33,4 & 32,8 & 0,6 \\
\hline 17 & C9 & 43,6 & 42,9 & 0,7 \\
\hline 18 & F6 & 14,4 & 13,6 & 0,8 \\
\hline 19 & C1 & 70,7 & 69,7 & 1,0 \\
\hline 20 & F11 & 16,8 & 15,6 & 1,2 \\
\hline 21 & $\mathrm{~F} 2$ & 20,3 & 19,0 & 1,3 \\
\hline 22 & F7 & 18,9 & 17,5 & 1,4 \\
\hline 23 & F16 & 16,3 & 14,7 & 1,6 \\
\hline 24 & $\mathrm{~F} 4$ & 18,9 & 17,1 & 1,7 \\
\hline 25 & $\mathrm{~F} 5$ & 30,1 & 28,3 & 1,8 \\
\hline 26 & F9 & 24,7 & 22,3 & 2,5 \\
\hline 27 & C8 & 148,5 & 143,7 & 4,9 \\
\hline
\end{tabular}

$\left.{ }^{(}{ }^{*}\right) \mathrm{Xi} \mathrm{e} \mathrm{Yi}=$ valores de consumo médio em ms/mês/ligação

(*) F1 a F15 = áreas com VRP Fixa; C1 a C10 = áreas com VRP Automática

Dessa análise constata-se que os consumos médios das áreas de VRP C8 e C10, foram classificados como "outliers" devendo ser descartados nas análises. de: $n i=n^{0}$ de ocorrências em cada classe de consumo $\mathrm{fi}=$ freqüência relativa do $n^{0}$ de ocorrência/classe fac $=$ freqüência acumulada do $n^{0}$ de ocorrências Posição

\begin{tabular}{|c|c|c|}
\hline $1 \mathrm{Q}=$ & 7,3 & $-0,2$ \\
\hline $2 \mathrm{Q}=$ & 14,0 & 0,5 \\
\hline $3 \mathrm{Q}=$ & 20,8 & 1,3 \\
\hline $4 Q=$ & 27,5 & 4,9 \\
\hline$\| Q=$ & 1,5 & \\
\hline L1 = & $1 \mathrm{Q}-1,5 \| \mathrm{Q}$ & $-2,5$ \\
\hline L2 = & $1 \mathrm{Q}-3,0 \| \mathrm{Q}$ & $-4,7$ \\
\hline $\mathrm{U} 1=$ & $3 Q+1,5 \| Q$ & 3,6 \\
\hline $\mathrm{U} 2=$ & $3 Q+3,0 \| Q$ & 5,8 \\
\hline \multicolumn{3}{|c|}{0,5} \\
\hline onde: & \\
\hline $1 \mathrm{Q}=$ & \multicolumn{2}{|c|}{ ( $1^{\circ}$ quartil) } \\
\hline $2 \mathrm{Q}=$ & \multicolumn{2}{|c|}{ ( $2^{\circ}$ quartil) } \\
\hline $3 Q=$ & \multicolumn{2}{|c|}{ ( $3^{\circ}$ quartil) } \\
\hline $4 Q=$ & \multicolumn{2}{|c|}{ ( $4^{\circ}$ quartil) } \\
\hline$\| Q=$ & \multicolumn{2}{|c|}{ (intervalo interquartil) } \\
\hline $\mathrm{L} 1=$ & \multirow{2}{*}{\multicolumn{2}{|c|}{$\begin{array}{l}\text { grade interna inferior } \\
\text { grade externa inferior }\end{array}$}} \\
\hline $\mathrm{L} 2=$ & & \\
\hline $\mathrm{U} 1=$ & \multicolumn{2}{|c|}{ grade interna superior } \\
\hline
\end{tabular}


FIGURA 3.13 - Gráfico do box plot, para a Análise 2 - Áreas Controladas por VRP

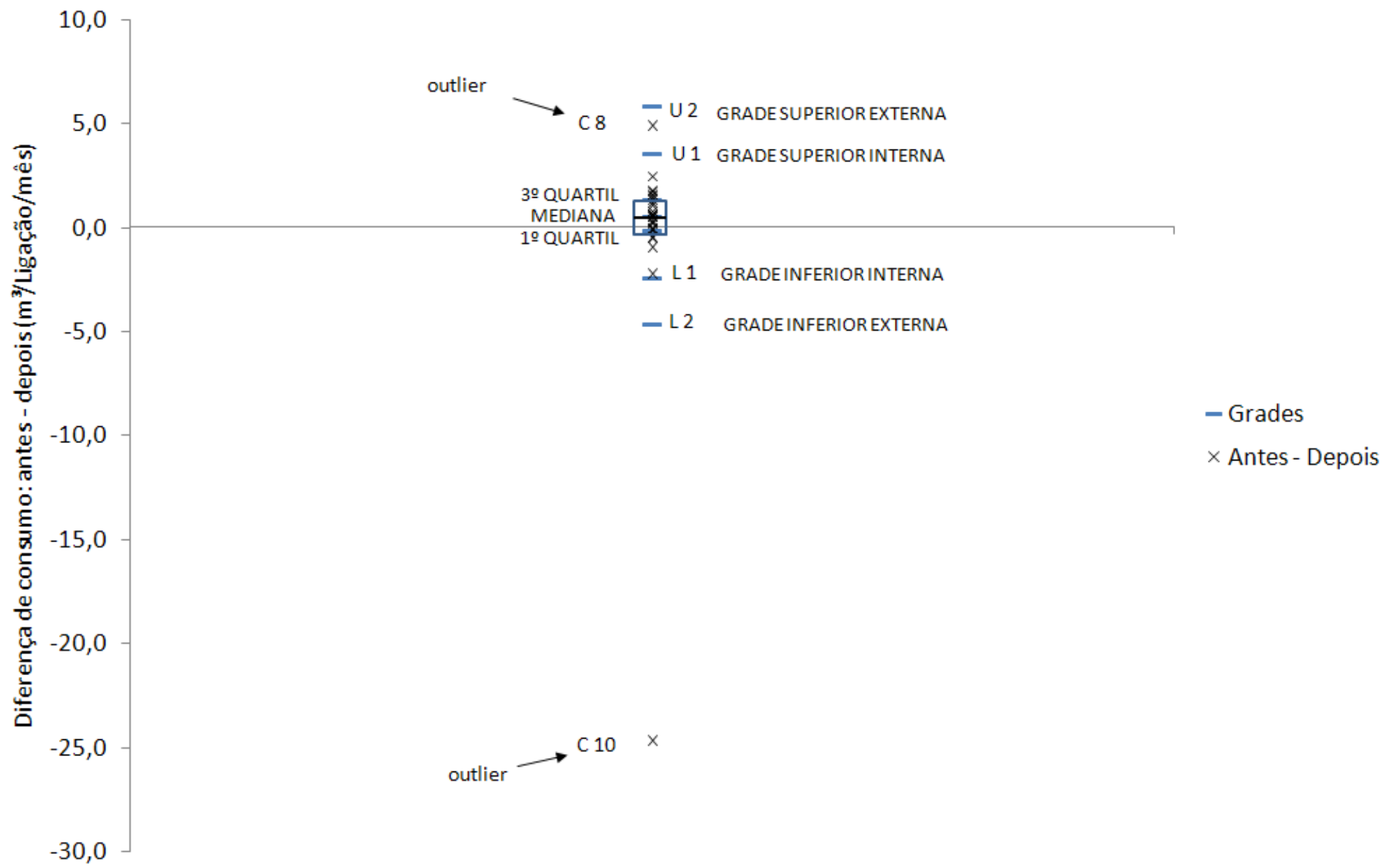




\section{Quadro 3.4 - Exemplo de planilha de cálculo de teste de hipóteses}

ANÁLISE 2: ÁREAS DE VRP

TESTE DE HIPÓTESE DAS MÉDIAS DE CONSUMO ANTES E APÓS A REDUÇÃO DE PRESSÃO PROVOCADA PELA INSTALAÇÃO DA VRP

\begin{tabular}{|c|c|c|c|c|c|c|}
\hline & VRP & ANTES (Xi) & APÓS (Yi) & $\mathrm{Di}=(\mathrm{Xi}-\mathrm{Yi})$ & Di - MD & $(\mathrm{Di}-\mathrm{MD})^{2}$ \\
\hline 1 & $\mathrm{C} 5$ & 16,8 & 17,8 & $-1,0$ & $-1,6$ & 2,5 \\
\hline 2 & $\mathrm{~F} 13$ & 22,9 & 23,4 & $-0,5$ & $-1,1$ & 1,2 \\
\hline 3 & C6 & 16,3 & 16,9 & $-0,5$ & $-1,1$ & 1,2 \\
\hline 4 & F14 & 20,3 & 20,8 & $-0,5$ & $-1,1$ & 1,1 \\
\hline 5 & $\mathrm{~F} 8$ & 26,1 & 26,3 & $-0,2$ & $-0,8$ & 0,6 \\
\hline 6 & F12 & 18,8 & 18,9 & $-0,1$ & $-0,7$ & 0,5 \\
\hline 7 & $\mathrm{~F} 1$ & 15,8 & 16,0 & $-0,1$ & $-0,7$ & 0,5 \\
\hline 8 & C7 & 18,8 & 18,7 & 0,2 & $-0,4$ & 0,2 \\
\hline 9 & F3 & 17,3 & 17,0 & 0,2 & $-0,3$ & 0,1 \\
\hline 10 & C4 & 26,7 & 26,4 & 0,3 & $-0,3$ & 0,1 \\
\hline 11 & F10 & 43,9 & 43,4 & 0,5 & $-0,1$ & 0,0 \\
\hline 12 & F17 & 14,7 & 14,2 & 0,5 & $-0,1$ & 0,0 \\
\hline 13 & $\mathrm{C} 2$ & 34,1 & 33,5 & 0,5 & 0,0 & 0,0 \\
\hline 14 & C3 & 33,4 & 32,8 & 0,6 & 0,1 & 0,0 \\
\hline 15 & C9 & 43,6 & 42,9 & 0,7 & 0,1 & 0,0 \\
\hline 16 & F6 & 14,4 & 13,6 & 0,8 & 0,2 & 0,0 \\
\hline 17 & C1 & 70,7 & 69,7 & 1,0 & 0,4 & 0,2 \\
\hline 18 & F11 & 16,8 & 15,6 & 1,2 & 0,6 & 0,4 \\
\hline 19 & F2 & 20,3 & 19,0 & 1,3 & 0,7 & 0,5 \\
\hline 20 & F7 & 18,9 & 17,5 & 1,4 & 0,9 & 0,7 \\
\hline 21 & F16 & 16,3 & 14,7 & 1,6 & 1,0 & 1,0 \\
\hline 22 & $\mathrm{~F} 4$ & 18,9 & 17,1 & 1,7 & 1,2 & 1,3 \\
\hline 3 & $\mathrm{~F} 5$ & 30,1 & 28,3 & 1,8 & 1,2 & 1,5 \\
\hline 24 & $\mathrm{F9}$ & 24,7 & 22,3 & 2,5 & 1,9 & 3,6 \\
\hline
\end{tabular}

(*) Xi e Yi- valores médios de consumo em $\mathrm{m}^{3} / \mathrm{mês} /$ ligação

$\left.{ }^{(\star \star}\right)$ F1 a F17: áreas com VRP Fixa

Características de Di: AMPLITUDE: 3,5

MÉDIA (MD): 0,6

MEDIANA: $\quad 0,5$

$\mathrm{H} 0: \mathrm{MD}=0$ (o consumo médio, antes e após a data de entrada em operação da VRP, não variou) $\mathrm{H} 1: \mathrm{MD} \neq 0$ (o consumo médio, antes e após a data de entrada em operação da VRP, variou)

Média: $\mathrm{MD}=0,6$

Variância: $\mathrm{SD}^{2}=\sum(\mathrm{Di}-\mathrm{MD})^{2} /(\mathrm{n}-1)=\quad 17,4 / 23=\quad 0,8$
Desvio Padrão: $\mathrm{SD}=\sqrt{0,8}=\quad 0,87$

$$
\mathrm{t}_{\mathrm{obs}}=\mathrm{MD} /(\mathrm{SD} / \sqrt{ }(\mathrm{n}))=\quad 0,6 / 0,87 / \sqrt{ } 24=3,262
$$

Na tabela de Distribuição Student:

graus de liberdade: $g l:(n-1)=23$

nível de significância: $\alpha=0,01$

$t_{\text {critico: }}$ tc $=2,807$

Como tobs $=3,262$ se encontra fora do intervalo de confiança - tc $=-2,807$ e tc $=2,807$, podemos rejeitar a hipótese $\mathrm{H} 0$ de que o consumo antes e após a data de entrada em operação da VRP não variou, quando consideradas as áreas de VRP.

Dessa forma, constata-se uma tendência à redução do consumo médio (variação positiva da relação Antes - Após), na média geral das áreas avaliadas. 
Após essas análises antes $\mathrm{x}$ depois, foram feitas análises comparativas entre áreas controladas por VRP e suas respectivas áreas testemunha, com o objetivo de se avaliar se as variações no consumo, constatadas nas análises antes $\mathrm{x}$ depois, podem ter sofrido influência da redução de pressão, provocada pela instalação de VRPs.

Essas análises, relacionadas no Quadro 3.5, se consistiram em testes paramétricos de hipóteses, diferenciando-se das primeiras, por se tratar de teste de hipóteses para comparação de duas médias de populações diferentes.

Quadro 3.5 - Análises comparativas entre áreas controladas por VRP e suas respectivas áreas testemunha

Análise 8 Comparação da diferença entre os consumos antes e depois, do conjunto de áreas controladas por VRP com saída fixa de pressão, com as diferenças de consumos antes e depois do conjunto de áreas testemunha de VRP com saída fixa.

Análise 8.1 A mesma comparação descrita na Análise 8, contemplando o conjunto de ligações com até 12 economias.

Análise 8.2 A mesma comparação descrita na Análise 8, contemplando o conjunto de ligações com até três economias.

Análise 8.3 A mesma comparação descrita na Análise 8, contemplando o conjunto de ligações abastecendo uma única economia.

Análise 9 Comparação da diferença entre os consumos antes e depois, do conjunto de áreas sob influência de VRP com controle automático de pressão, com as diferenças de consumos antes e depois do conjunto de áreas testemunha de VRP com controle automático.

Análise 9.1 A mesma comparação descrita na Análise 9, contemplando o conjunto de ligações com até 12 economias.

Análise 9.2 A mesma comparação descrita na Análise 9, contemplando o conjunto de ligações com até três economias.

Análise 9.3 A mesma comparação descrita na Análise 9, contemplando o conjunto de ligações abastecendo uma única economia.

Análise 10 Comparação da diferença entre os consumos antes e depois, do conjunto de áreas controladas por VRP, com as diferenças de consumos antes e depois do conjunto de áreas testemunha de VRP. 


\section{CARACTERIZAÇÃO DA ÁREA DE ESTUdO DE CASO}

Neste capítulo, são apresentadas as principais características, da área onde foi desenvolvido o estudo de caso, relativas ao sistema de distribuição e ao consumo de água.

A área selecionada para o estudo de caso, da pesquisa em pauta, é a Região Metropolitana do Estado de São Paulo (RMSP).

A RMSP é formada pela Cidade de São Paulo, Capital do Estado de São Paulo, e mais 38 municípios do Estado. Na Figura 4.1 é apresentado o Mapa do Brasil com a indicação da localização do Estado de São Paulo e o Mapa do Estado de São Paulo, com a indicação da RMSP.
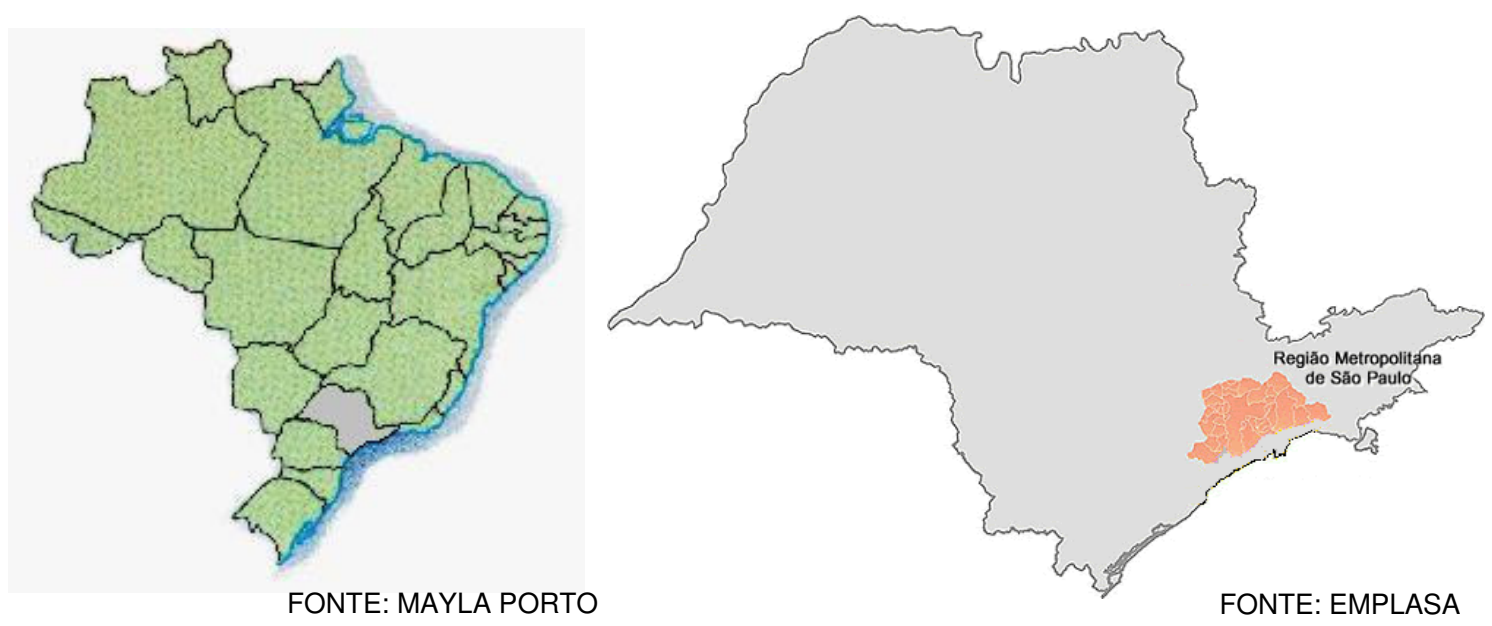

FIGURA 4.1 - Localização do Estado de São Paulo, no Mapa do Brasil, e da RMSP, no Mapa do Estado de São Paulo (adaptações nossas)

(*) mapas sem escala; Norte na direção vertical, para cima

Na Figura 4.2, é apresentado o mapa indicando a RMSP, com os limites dos 39 municípios que formam a Região.

Desses municípios, a Sabesp distribui água diretamente para vinte e nove, sendo exceções os municípios de: Guarulhos, Santa Isabel, Guararema, ao Norte; Mauá, São Caetano do Sul, Santo André, Diadema, São Lourenço da Serra e Juquitiba, ao Sul; e em parte do Município de Mogi das Cruzes, a Leste. 


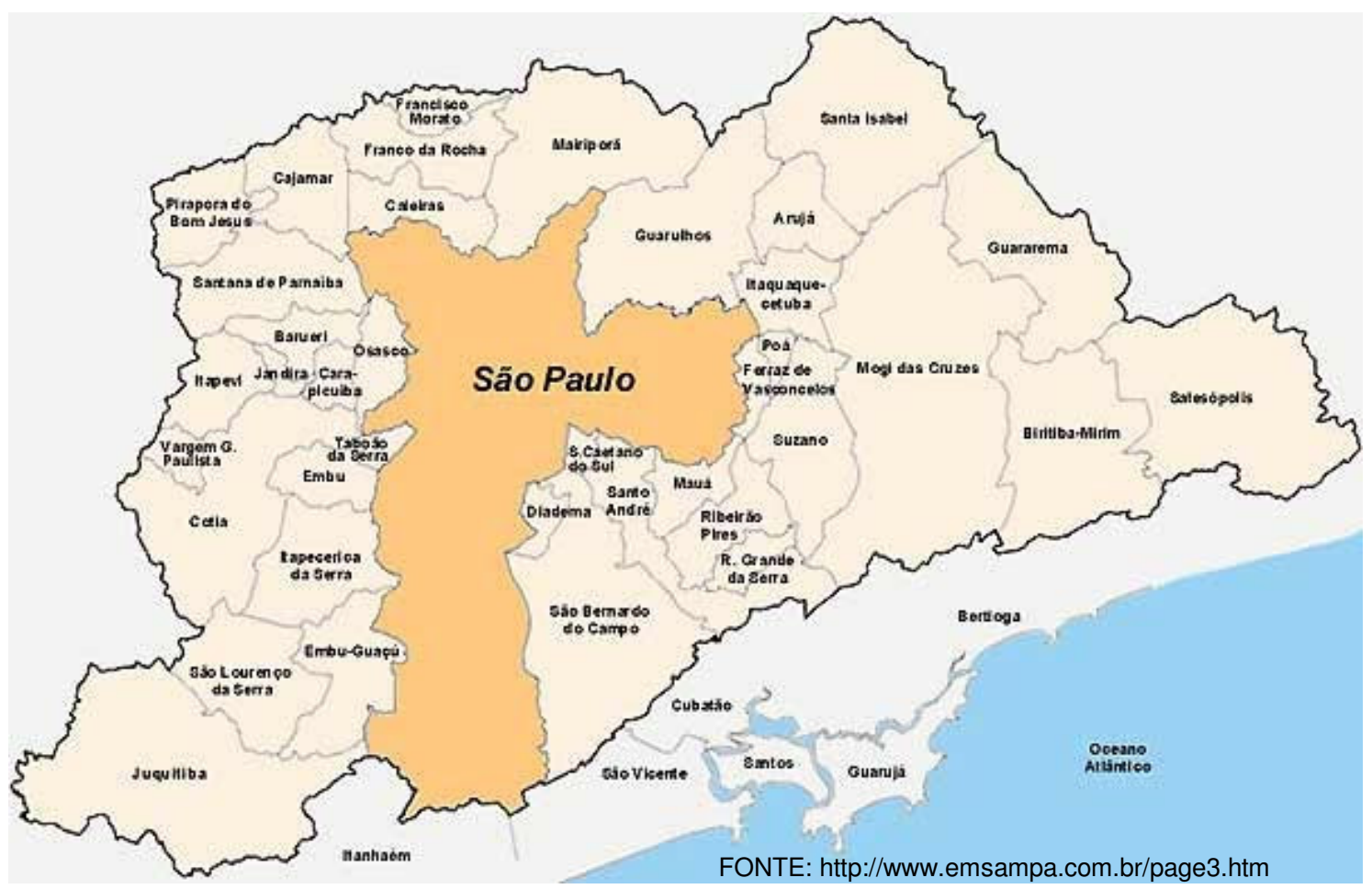

FIGURA 4.2 - Mapa com os municípios que formam a RMSP

(*) mapa sem escala; Norte na direção vertical, para cima

Com uma área de $8.051 \mathrm{~km}^{2}$, a RMSP possui, conforme o Instituto Brasileiro de Geografia e Estatística (IBGE), uma população de 19.677.506 habitantes, com base em dados de 2006.

No Quadro 4.1, são apresentadas as principais características do abastecimento de água da RMSP, nos municípios com rede de distribuição de água operada diretamente pela Sabesp.

Quadro 4.1 - Características do abastecimento de água na RMSP

\begin{tabular}{lr}
\hline Rede de distribuição de água (km) & 29.378 \\
Adutoras $(\mathrm{km})$ & 1.085 \\
Reservatórios (un.) & 373 \\
Capacidade de armazenamento (milhões de m³) & 1,8 \\
Estações de Tratamento de Água (ETAs) (un.) & 28 \\
Vazão média produzida (m³/s) & 67 \\
\hline
\end{tabular}


Na Figura 4.3, é apresentada foto de satélite onde se vê a mancha urbana formada pela RMSP, com indicação dos pontos de localização aproximada das áreas controladas por VRP, selecionadas para a presente pesquisa.

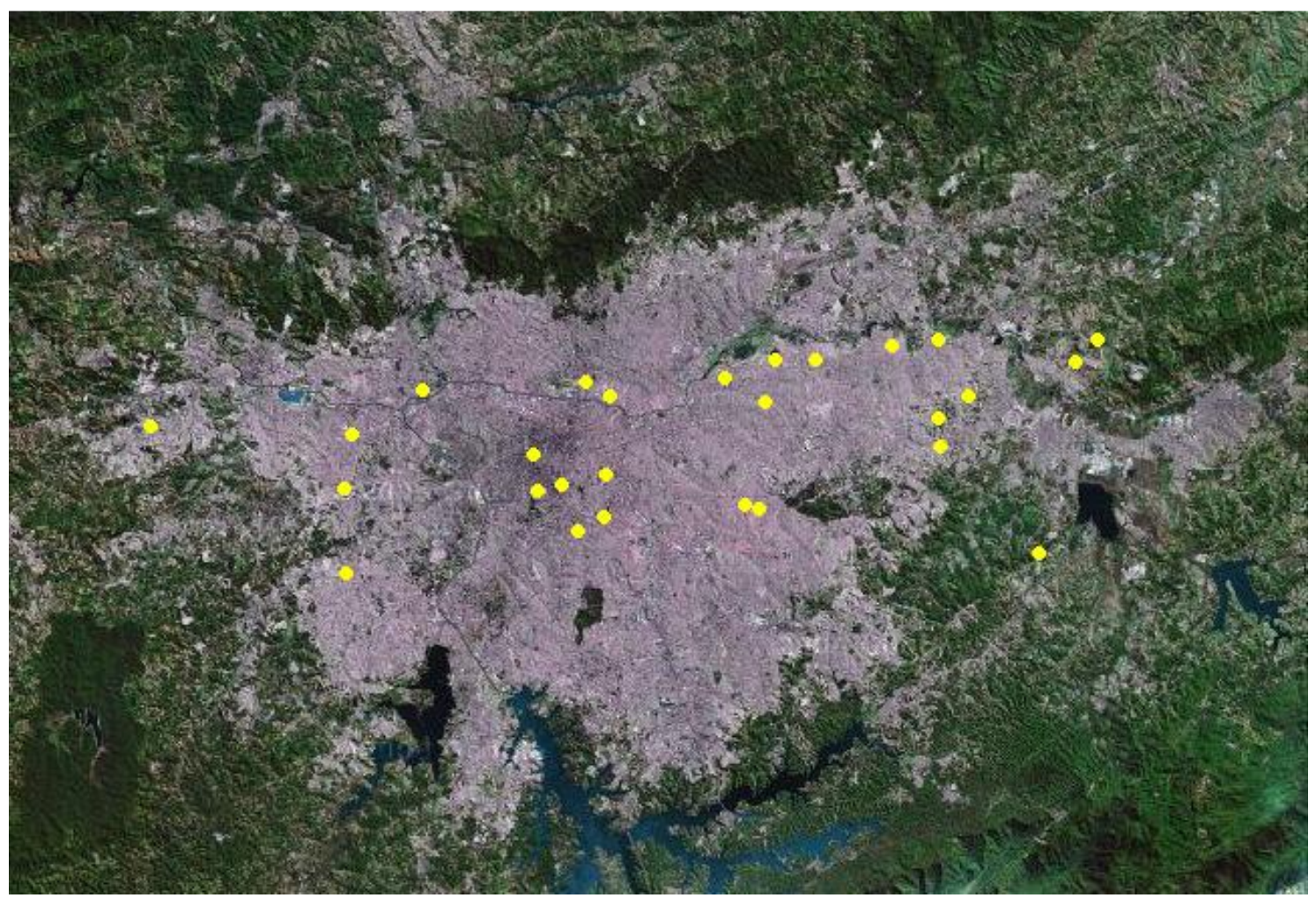

FONTE: http://www.google.com/maps (Foto); Signos - Sabesp (georreferenciamento)

FIGURA 4.3 - Localização, na RMSP, das áreas de VRP em análise

(*) imagem sem escala; Norte na direção vertical, para cima 


\section{RESULTADOS}

Neste capítulo, são sumarizados os resultados obtidos nos testes de consistência dos dados (box plot) e nos testes de hipóteses realizados.

Das análises de consistência, das séries de dados de diferença de média de consumo, na situação antes $x$ depois, elaboradas através da aplicação da técnica de box plot, foram considerados outiliers e, conseqüentemente, foram descartados das análises estatísticas de significância (testes de hipóteses), os dados das áreas relacionadas no Quadro 5.1.

Quadro 5.1. - Sumário dos resultados das análises de consistência (box plot)

\begin{tabular}{|c|c|c|}
\hline CONJUNTO & \multicolumn{2}{|c|}{ ÁREAS DESCARTADAS } \\
\hline \multirow{2}{*}{ Áreas de VRP + Áreas Testemunha (TEST) } & VRP & C8; C10; F15 \\
\cline { 2 - 3 } & TEST & C3; C10; F5 \\
\hline Áreas de VRP & VRP & C8; C10; F15 \\
\hline Áreas Testemunha & TEST & C3; C10; F5 \\
\hline Áreas de VRP com Controle Automático de Pressão & VRP & C8; C10 \\
\hline Áreas Testemunha de VRP com Saída Fixa de Pressão & TEST & F5; F14 \\
\hline Áreas Testemunha de VRP Fixa (até 12 economias/Ligação) & TEST & F14 \\
\hline Áreas Testemunha de VRP - Controle Automático de Pressão & TEST & C3; C10 \\
\hline
\end{tabular}

Nos demais conjuntos de áreas, estabelecidos para as análises, não foram identificados outiliers, nas séries de dados de diferenças de média de consumo.

Na seqüência, são apresentados os resultados dos testes de hipóteses.

a) Para o conjunto de todas as áreas em estudo, formado pelas áreas controladas por VRP e pelas áreas testemunha, os resultados mostraram que existem boas evidências de que o consumo geral reduziu, após a data de entrada em operação das VRPs.

b) Quando se considera o conjunto formado, apenas, pelas áreas controladas por VRP, os resultados, da mesma forma, mostraram que existem boas evidências 
de que o consumo médio geral das ligações reduziu, após a data de implementação da redução de pressão de distribuição.

c) Quando se considera o conjunto formado, apenas, pelas áreas testemunha, não existem boas evidências para se afirmar que houve redução no consumo médio das ligações. Considera-se, nesse caso, que o consumo médio das ligações não variou, após a data de implementação da redução de pressão de distribuição.

Mudando o foco para os subconjuntos das áreas de VRP:

d) Considerando-se, primeiramente, o conjunto de áreas de VRP com saída fixa de pressão, os resultados dos testes mostraram que não existem boas evidências de que o consumo no conjunto dessas áreas tenha variado.

Prosseguindo com os resultados do conjunto das áreas sob controle de VRP com saída fixa de pressão:

Quando se consideram as ligações que abastecem até 12 economias, os resultados mostraram haver boas evidências de que o consumo médio dessas ligações reduziu, após a data de entrada em operação das VRPs.

O mesmo se pode afirmar para as ligações que abastecem até três economias e para as ligações que abastecem uma única economia.

e) Passando-se ao conjunto de áreas de VRP com controle automático de pressão, não existem boas evidências de que o consumo médio dessas ligações tenha variado, após a data de entrada em operação das VRPs.

Chegou-se ao mesmo resultado para todas as configurações estudadas para as áreas sob influência de VRP com controle automático de pressão (até 12 economias, por ligação; até três economias; e uma única economia, por ligação), podendo ser considerado que nesse tipo de área o consumo médio das ligações não variou.

Passando-se, então, à avaliação do comportamento do consumo médio nas ligações pertencentes ao subconjunto das áreas testemunha de áreas de VRP:

f) Considerando-se o conjunto de áreas testemunha de áreas controladas por VRP com saída fixa de pressão, os resultados dos testes de hipóteses, para o conjunto e para todas as suas configurações, mostraram que existem boas evidências para se afirmar que o consumo médio nessas áreas sofreu uma 
redução, após a data de entrada em operação das VRPs. Convém lembrar que essas áreas não sofrem influência da redução de pressão provocada pelas VRPs.

g) Finalmente, quando se considera o conjunto das áreas testemunha de áreas sob influência de VRPs com controle automático de pressão, o resultado dos testes de hipóteses foi o mesmo, para todas as configurações, mostrando que não existem boas evidências para se afirmar que houve variação no consumo médio das ligações localizadas no interior dessas áreas, após a data de entrada em operação das VRPs.

Os resultados dos testes de hipóteses encontram-se sumarizados no Quadro 5.2.

Quanto aos resultados dos testes de hipósteses, convém destacar que, para todos os casos em que a hipótese nula não pôde ser rejeitada (isto é, não se têm boas evidências para se afirmar que o consumo variou), esse resultado se verifica tanto para o nível de significância de $5 \%$, quanto para o de $1 \%$.

Para os casos em que a hipótese nula foi rejeitada (isto é, têm-se boas evidências de que o consumo variou), quando o nível de significância indicado nos resultados dos testes de hipóteses foi de $1 \%$, esse resultado se verifica tanto para o nível de significância de $1 \%$, quanto para o de $5 \%$. Já, quando o nível de significância indicado é de $5 \%$, a hipótese nula foi rejeitada para esse nível de significância, mas não pôde ser rejeitada para o nível de $1 \%$. 
Quadro 5.2 - Resumo dos resultados obtidos nos testes de hipóteses

\begin{tabular}{|c|c|c|c|c|c|}
\hline \multicolumn{2}{|r|}{ ANÁLISE } & \multirow{2}{*}{$\begin{array}{l}\text { Região de Aceitação da Hipótese } \mathrm{H}_{0} \\
\text { IC }=\left(-\mathrm{t}_{\text {crítico }}<\mathrm{t}<\mathrm{t}_{\text {crítico }}\right) \\
-2,680<\mathrm{t}<2,680\end{array}$} & \multirow{2}{*}{$\begin{array}{c}t_{\text {observado }} \\
3,738\end{array}$} & \multirow{2}{*}{$\begin{array}{c}\text { Resultados } \\
\text { Reduziu }\end{array}$} & \multirow{2}{*}{$\begin{array}{c}\text { Nível de } \\
\text { Significância } \\
1 \%\end{array}$} \\
\hline 1 & Médias áreas de VRP + testemunha & & & & \\
\hline 2 & Médias áreas de VRP & $-2,807<\mathrm{t}<2,807$ & 3,262 & Reduziu & $1 \%$ \\
\hline 3 & Médias áreas testemunha & $-2,069<t<2,069$ & 2,062 & Não Variou & $5 \%$ \\
\hline 4 & Médias áreas de VRP Saída Fixa & $-2,120<t<2,120$ & 2,069 & Não Variou & $5 \%$ \\
\hline 4.1 & VRP Fixa (até 12 economias por ligação) & $-2,120<t<2,120$ & 2,461 & Reduziu & $5 \%$ \\
\hline 4.2 & VRP Fixa (até 3 economias por ligação) & $-2,120<t<2,120$ & 2,495 & Reduziu & $5 \%$ \\
\hline 4.3 & VRP Fixa (1 economia por ligação) & $-2,120<t<2,120$ & 2,435 & Reduziu & $5 \%$ \\
\hline 5 & Médias áreas de VRP Controle Automático & $-2,365<t<2,365$ & 0,951 & Não Variou & $5 \%$ \\
\hline 5.1 & VRP Autom. (até 12 economias por ligação) & $-2,262<t<2,262$ & 1,141 & Não Variou & $5 \%$ \\
\hline 5.2 & VRP Autom. (até 3 economias por ligação) & $-2,262<t<2,262$ & 1,061 & Não Variou & $5 \%$ \\
\hline 5.3 & VRP Autom. (1 economia por ligação) & $-2,262<t<2,262$ & 1,059 & Não Variou & $5 \%$ \\
\hline 6 & Médias áreas testemunha FIXA & $-2,977<\mathrm{t}<2,977$ & 4,066 & Reduziu & $5 \%$ \\
\hline 6.1 & A T FIXA (até 12 economias por ligação) & $-2,947<\mathrm{t}<2,947$ & 4,211 & Reduziu & $1 \%$ \\
\hline 6.2 & A T FIXA (até 3 economias por ligação) & $-2,120<t<2,120$ & 2,631 & Reduziu & $5 \%$ \\
\hline 6.3 & A T FIXA (1 economia por ligação) & $-2,921<t<2,921$ & 3,262 & Reduziu & $1 \%$ \\
\hline 7 & Médias áreas testemunha AUTOMÁTICA & $-2,365<t<2,365$ & $-0,044$ & Não Variou & $5 \%$ \\
\hline 7.1 & A T AUTOM. (até 12 economias por ligação) & $-2,262<t<2,262$ & 0,654 & Não Variou & $5 \%$ \\
\hline 7.2 & A T AUTOM. (até 3 economias por ligação) & $-2,262<t<2,262$ & 0,571 & Não Variou & $5 \%$ \\
\hline 7.3 & A T AUTOM. (1 economia por ligação) & $-2,262<t<2,262$ & 0,680 & Não Variou & $5 \%$ \\
\hline
\end{tabular}

OBS.: $\mathrm{A} \mathrm{T}=$ área testemunha; Autom. = controle automático de pressão; Fixa = saída fixa de pressão; IC = Intervalo de Confiança 
Dos testes de hipóteses realizados para verificação de possível diferença de comportamento na tendência de consumo médio, entre as áreas controladas por VRP e suas respectivas áreas testemunha, pode-se concluir, para todos os conjuntos e configurações analisados, que não existem boas evidências estatísticas de que o comportamento do consumo nas áreas controladas por VRP foi diferente do comportamento do consumo nas suas respectivas áreas testemunha, tanto para o nível de significância de 5\%, quanto para o nível de significância de $1 \%$.

Em outras palavras, as tendências de variação no consumo, confirmadas em várias das análises antes $\mathrm{x}$ depois, não se mostraram estatisticamente significativas, quando comparadas as áreas controladas por VRP com suas respectivas áreas testemunhas.

Dessa forma, considera-se que, para as áreas controladas por VRP, relacionadas no Quadro 5.3, não se pode afirmar que a redução na pressão de distribuição tenha influenciado o consumo das ligações de água nessas áreas. 
Quadro 5.3 - Resumo dos resultados dos testes de hipóteses entre consumos de áreas de VRP e consumos de áreas testemunha

\begin{tabular}{|c|c|c|c|c|c|}
\hline & ANÁLISE & Região de Aceitação da Hipótese $\mathrm{H}_{0}$ & $t_{\text {observado }}$ & Resultados & Nível de \\
\hline 8 & Testemunha $x$ VRP Fixa & $-2,042<\mathrm{t}<2,042$ & 0,589 & $\begin{array}{c}\text { Mesma } \\
\text { Variação }\end{array}$ & $5 \%$ \\
\hline 8.1 & Testemunha x VRP Fixa (até 12 econ./lig.) & $-2,042<\mathrm{t}<2,042$ & 0,560 & $\begin{array}{c}\text { Mesma } \\
\text { Variação }\end{array}$ & $5 \%$ \\
\hline 8.2 & Testemunha x VRP Fixa (até 3 econ./lig.) & $-2,042<\mathrm{t}<2,042$ & $-0,185$ & $\begin{array}{c}\text { Mesma } \\
\text { Variação }\end{array}$ & $5 \%$ \\
\hline 8.3 & Testemunha x VRP Fixa (1 econ./lig.) & $-2,042<\mathrm{t}<2,042$ & 0,153 & $\begin{array}{c}\text { Mesma } \\
\text { Variação }\end{array}$ & $5 \%$ \\
\hline 9 & Testemunha x VRP Controle Automático & $-2,145<\mathrm{t}<2,145$ & $-0,607$ & $\begin{array}{c}\text { Mesma } \\
\text { Variação }\end{array}$ & $5 \%$ \\
\hline 9.1 & Testemunha x VRP Autom. (até 12 econ./lig.) & $-2,101<\mathrm{t}<2,101$ & 0,053 & $\begin{array}{c}\text { Mesma } \\
\text { Variação }\end{array}$ & $5 \%$ \\
\hline 9.2 & Testemunha x VRP Autom. (até 3 econ./lig.) & $-2,101<\mathrm{t}<2,101$ & $-0,069$ & $\begin{array}{c}\text { Mesma } \\
\text { Variação }\end{array}$ & $5 \%$ \\
\hline 9.3 & Testemunha x VRP Autom. (1 econ./lig.) & $-2,101<\mathrm{t}<2,101$ & 0,049 & $\begin{array}{c}\text { Mesma } \\
\text { Variação }\end{array}$ & $5 \%$ \\
\hline 10 & Áreas Testemunha x Áreas de VRP & $-2,010<\mathrm{t}<2,010$ & $-0,646$ & $\begin{array}{c}\text { Mesma } \\
\text { Variação }\end{array}$ & $5 \%$ \\
\hline
\end{tabular}




\section{CONSIDERAÇÕES E COMENTÁRIOS}

Neste capítulo, são feitas considerações e comentários, baseados nos resultados das análises, quanto à variação do consumo, e na comparação entre as áreas selecionadas para a pesquisa.

Fazendo-se uma análise dos resultados das comparações estatísticas, realizadas através dos testes de hipóteses, são focados, inicialmente, os três grupos principais das áreas estudadas: a) conjunto formado por todas as áreas de VRP $e$ testemunhas; b) conjunto formado pelas áreas de VRP; c) conjunto formado pelas áreas testemunha. Pode-se observar:

I. A média de consumo do conjunto formado pelas áreas de VRP e áreas testemunha apresentou redução, após as datas de entrada em operação das VRPs.

II. A média de consumo do conjunto formado, apenas, pelas áreas de VRP, também apresentou redução.

III. A média de consumo do conjunto formado, apenas, pelas áreas testemunha, não apresentou variação.

Como o conjunto de áreas descrito em I representa a soma dos conjuntos descritos em II e III, pode-se deduzir que a tendência de redução no consumo, observada em áreas de VRP, pode ter influenciado o resultado de I, uma vez que as áreas testemunha não apresentaram a mesma tendência.

Passando-se à análise dos resultados dos subconjuntos, desses três grupos principais de áreas, primeiramente, dos resultados do conjunto de áreas de VRP com saída fixa de pressão, observa-se que, quando se consideram somente as ligações que abastecem doze economias, ou menos, houve uma redução no consumo. No entanto, essa tendência não foi confirmada quando se analisaram todas as ligações no interior desse conjunto de áreas.

Esse fato poderia indicar que o valor médio de consumo dos grandes consumidores localizados nessas áreas, não sofreu redução, influenciando o resultado geral do conjunto. Entretanto, essa análise não foi explorada neste trabalho. 
Com mesmo teor da análise anterior, o conjunto formado por áreas testemunha de áreas de VRP com saída fixa de pressão, também, apresentou redução no consumo, não estando sob influência de redução de pressão no abastecimento.

Os testes de hipóteses utilizados na comparação da variação da diferença de consumo médio das áreas de VRP com saída fixa, em contraposição às suas áreas testemunha, mostraram que não foi verificada diferença significativa entre 0 comportamento do consumo, nas duas áreas.

Com esses resultados, não se pode afirmar que a redução no consumo, verificada nessas áreas, se deve à implantação de VRPs, existindo outros fatores que podem ter motivado tal redução, como fatores climáticos e fatores de ordem econômica, dentre outros, fatores cuja influência não foi explorada nesta pesquisa.

Quanto aos conjuntos formados pelas áreas sob influência de VRP com controle automático de pressão e suas respectivas áreas testemunha, os resultados dos testes mostraram que não ocorreu alteração significativa nos seus níveis de consumo médio.

Da mesma forma, quando comparados um contra o outro, também não foi observada diferença de comportamento de consumo entre as áreas sob influência de VRP com controle automático de pressão e suas respectivas áreas testemunha.

Voltando o foco, agora, somente para os subconjuntos formados por áreas controladas por VRP com controle automático de pressão e por áreas controladas por VRP com saída fixa de pressão, um contra o outro, pode-se notar, nas configurações com doze economias por ligação, ou menos, que o consumo médio total de cada um desses subconjuntos teve comportamento diferente: as áreas controladas por VRP com saída fixa de pressão apresentaram uma redução no consumo, o que não ocorreu com as áreas sob influência de VRP com controle automático de pressão.

Uma vez que foi demonstrado que não se pode confirmar a influência da redução de pressão, no consumo, mais uma vez, outros fatores podem ter motivado esse comportamento, que não a instalação de VRPs. 


\section{CONCLUSÕES}

Após as considerações feitas no capítulo anterior, pôde-se chegar às seguintes conclusões:

Nas $48^{1}$ áreas analisadas, em conjunto, o consumo médio total das ligações apresentou redução, após as datas de entrada em operação das VRPs. No entanto, esse efeito não pode ser creditado à redução de pressão de distribuição de água, provocada pela instalação de VRPs, como demonstrado pelos resultados dos testes de hipóteses, devendo ser creditado a outros fatores que influenciam o consumo. Tais fatores podem estar relacionados, desde a um aumento tarifário, que tenha aumentado a participação do custo da água no orçamento dos consumidores, a variações climáticas nos períodos em que foram apropriados os consumos utilizados na pesquisa, até a uma mudança de comportamento dos consumidores, incorporando hábitos preconizados pelos programas de uso racional da água, como a adoção de equipamentos economizadores de água e mudanças de hábitos de consumo. No entanto, a análise da influência desses fatores não foi explorada nesta pesquisa.

Com base nos resultados dos testes de hipóteses, para comparação entre áreas controladas por VRP e áreas testemunha (sem influência da redução de pressão), pode-se concluir que, na configuração mais geral do sistema de distribuição de água da RMSP, a redução de pressão implementada pela instalação de VRPs, não provoca variação significativa no consumo médio das ligações de água. Esse fato se deve, muito provavelmente, às características de abastecimento indireto, generalizado nos consumidores da RMSP, que neutralizariam uma possível redução de consumo, que ocorreria no caso de abastecimento direto, afirmação, quanto ao abastecimento direto, feita pela literatura especializada, mas que não foi explorada nesta pesquisa.

Desse resultado, pode-se concluir, ainda, que a utilização de VRPs, em programas de uso racional da água, com a finalidade de induzir a uma redução involuntária de

\footnotetext{
${ }^{1}$ Das 54 áreas iniciais, os valores das diferenças de média de consumo de seis foram considerados outliers e descartados das análises comparativas.
} 
consumo, não é efetiva quando são considerados sistemas com abastecimento indireto, desde que respeitado o limite mínimo de pressão, estabelecido pela Norma Brasileira (pressão dinâmica mínima de 100 kPa - ABNT, 1994).

Quando se analisa o problema pelo enfoque da redução de faturamento das companhias de distribuição de água, fica evidente o efeito, aparentemente contraditório, provocado pelo abastecimento indireto (conjunto caixa d'água/torneira de bóia). Do ponto de vista das perdas de faturamento, devidas à submedição em hidrômetros de consumidores, a caixa d'água funciona como indutor do aumento do volume submedido, uma vez que a torneira de bóia, que controla o fluxo de água, na sua entrada, permite vazões abaixo da faixa de precisão dos hidrômetros. Do ponto de vista da instalação de válvulas redutoras de pressão, a característica de abastecimento indireto evita uma redução no consumo e, conseqüentemente, uma redução no faturamento das companhias.

A metodologia desenvolvida nesta pesquisa se mostrou adequada, para avaliar os dados disponíveis, com confiança e robustez. Pode ser, total ou parcialmente, utilizada, em outros sistemas de distribuição de água, com características diversas daquele que foi explorado. 


\section{RECOMENDAÇÕES}

Com base nos resultados, considerações, comentários e conclusões, podem ser feitas as seguintes recomendações.

I. Apesar de se ter constatado que, em sistemas caracterizados por abastecimento indireto ou, predominantemente indireto, não ocorre influência significativa da redução da pressão de abastecimento no consumo médio das ligações de água, recomenda-se que sejam feitos estudos, em laboratório, para se constatar a influência da redução de pressão em pontos abastecidos diretamente pela rede (abastecimento direto).

II. A realização de estudos, em casos reais, do efeito da redução de pressão nos pontos abastecidos diretamente pela rede (torneiras de cavalete ou de jardim; torneiras de tanque de lavar roupas; torneiras de cozinha; etc.) em imóveis localizados em áreas onde está prevista a implementação de redução da pressão de abastecimento, antes e após a entrada em operação das VRPs, através da instalação de medidores específicos e de registradores de dados e da medição da pressão correspondente, para se constatar o efeito real causado nesses pontos e a participação da possível variação no consumo desses pontos, no consumo geral desses imóveis.

III. A realização de estudos mais aprofundados de outros fatores (mudanças de hábito de consumo; efeito da tarifa; variações climáticas; etc.) que possam ter motivado a redução no consumo médio geral das áreas estudadas, constatada na pesquisa realizada. 


\section{REFERÊNCIAS BIBLIOGRÁFICAS}

ABNT. NBR 12218 - Projeto de rede de distribuição de água para abastecimento público. Associação Brasileira de Normas Técnicas - ABNT. Rio de Janeiro, 1994.

ABNT. NBR NM 212 - Medidores velocimétricos de água fria até $15 \mathrm{~m}^{3} / \mathrm{h}$. Associação Brasileira de Normas Técnicas - ABNT. Rio de Janeiro, 1999.

ABNT. NBR 14534 - Torneira de bóia para reservatórios prediais de água potável: requisitos e métodos de ensaio. Associação Brasileira de Normas Técnicas - ABNT. Rio de Janeiro, 2000.

ALEM SOBRINHO, P.; MARTINS, G. Abastecimento de Água. In TSUTIYA, MILTON T. (Org.) et al. Abastecimento de Água. 1a ed. São Paulo: Departamento de Engenharia Hidráulica e Sanitária da Escola Politécnica da Universidade de São Paulo, 2004.

AMERICAN WATER WORKS ASSOCIATION - AWWA. Water Audits and Leak Detection: Manual of Water Supply Practices - M36, $2^{\text {nd }}$ ed. Denver: AWWA, 1999.

AWWARF - AWWA Research Foundation. Water and Revenue Losses: Unaccounted-for Water. Denver: AWWARF / AWWA, 1987.

BARTH, FLÁVIO T. Aspectos institucionais do gerenciamento de recursos hídricos. In REBOUÇAS, A. da C. et al. Águas Doces no Brasil: Capital ecológico, uso e conservação. $2^{\underline{a}}$ ed. São Paulo: Escrituras Editora e Distribuidora de Livros Ltda., 2002.

BUTLER, DAVID. Leakage Detection and Management: a comprehensive guide to technology and practice in the water supply industry. Cwmbran: Palmer Environmental, 2000.

COELHO, A. C.; MAYNARD J. C. de B. Medição Individualizada de Apartamentos em Edifícios Multi-Familiares. 19 Congresso Brasileiro de Engenharia Sanitária e Ambiental - Anais do Congresso. Foz do Iguaçu: ABES, 1997. Disponível em <http://www.bvsde.paho.org/bvsacd/abes97/edifícios.pdf> Acesso em 26/05/2007.

CSB/SJU - COLLEGE OF SAINT BENEDICT AND SAINT JOHN'S UNIVERSITY. Tools for Science web page. Disponível em <http://www.physics.csbsju.edu/stats/ display.distribution.html> Acesso em 08/05/2007. 
FARLEY, MALCOLM; TROW, STUART. Losses in Water Distribution Networks: a practioner's guide to assessment, monitoring and control. $1^{\text {st }}$ ed. London: IWA Publishing, 2003.

GOMES, HEBER. P. Sistemas de Abastecimento de Água: Dimensionamento Econômico. João Pessoa: Editora Universitária - UFPB, 2004.

GUMBO, B.; VAN DER ZAAG, P. Water losses and the political constraints to demand management: the case of the City of Mutare, Zimbabwe. $2^{\text {nd }}$ WARFSA/WaterNet Symposium: Integrated Water Resources Management: Theory, Practice, Cases; Cape Town, 2001. Disponível em <http://webworld.unesco.org/ water/wwap/pccp/cd/pdf/educational_tools/course_modules/reference_documents/sh aringinternwatercases/waterlosses.pdf> Acesso em abril de 2007.

HASSEGAWA, C. M.; ZAHED FILHO, K.; IGNÁCIO, R. V. V. Caracterização dos perfis de consumo da região metropolitana de São Paulo. Rio de Janeiro: Congresso Brasileiro de Engenharia Sanitária e Ambiental, 1999.

IPT - INSTITUTO DE PESQUISAS TECNOLÓGICAS. Determinação e caracterização da submedição no rol comum em cada unidade de negócio da Sabesp - RMSP. São Paulo: IPT, 2007.

IWA / BLUE PAGES. Losses from Water Supply Systems: Standard Terminology and Recommended Performance Measures. London: IWA Publishing, 2000.

LAMBERT, A. O. et al. A Review of Performance Indicators for Real Losses from Water Supply Systems. London: AQUA /IWA, 1999.

LAMBERT, A. O.; McKENZIE, R. Practical Experience in Using the Infrastructure Leakage Index. In LEMESOS 2002 - CONFERENCE. Leakage Management: A Practical Approach - Conference Proceedings. Lemesos: Water Board of Lemesos Cyprus / IWA, 2002.

LAVRADOR FILHO, J. Contribuição para o entendimento do reuso planejado da água e algumas considerações sobre suas possibilidades no Brasil. Dissertação de Mestrado. São Paulo: Escola Politécnica da Universidade de São Paulo, 1987.

MARCELLINI, SILVANA S. Diretrizes para utilização de tecnologia de Sistemas de Informação Geográfica (SIG) na exploração de informações hidrológicas: exemplos de aplicação. Tese de Doutorado. São Paulo: Escola Politécnica da Universidade de São Paulo, 2002. 
MORRISON, JOHN. Managing leakage by District Metered Areas: a practical approach. Water 21. London: IWA Publishing, 2004. Disponível em <http://www.iwapublishing.com/pdf/Water21_February_2004_-_Water_Loss.pdf> Acesso em abril de 2007.

OFWAT - Office of Water Services - England and Wales. Security of supply and the efficient use of water - 2004-2005 report. London: OFWAT, 2005. Disponível em <http://www.ofwat.gov.uk/aptrix/ofwat/publish.nsf/AttachmentsByTitle/leakage_0405.pdf/\$FILE/leakage_04-05.pdf> Acesso em julho de 2006.

OFWAT - Office of Water Services - England and Wales. Water Metering: Position Paper. London: OFWAT, 2006. Disponível em <www.ofwat.gov.uk/aptrix/ofwat/ publish.nsf/Content/navigation-positionpapers> Acesso em novembro de 2006.

REBOUÇAS, ALDO da C. et al. Águas Doces no Brasil: Capital ecológico, uso e conservação. $2^{\mathrm{a}}$ ed. São Paulo: Escrituras Editora e Distribuidora de Livros Ltda., 2002.

RECH, ANTÔNIO L. Água, Micromedição e Perdas. 1르. ed. Porto Alegre: Scortecci, 1992.

RIZZO, A.; CILIA, J. Quantifying Meter Under-Registration Caused by the Ball Valves of Roof Tanks (for Indirect Plumbing Systems). Leakage 2005 Specialized Conference - Conference Proceedings. Halifax: IWA, 2005.

SABESP/LYSA. Programa de Redução de Águas Não-Faturadas. Relatório Síntese, São Paulo: LYSA, 1993.

SABESP - MPC. Programa de Uso Racional da Água - PURA. São Paulo: Sabesp, 2006.

SABESP - MPI. Planos Integrados Regionais: Relatório Síntese - 2005. São Paulo: Diretoria Metropolitana - Sabesp, 2006.

SABESP - MPI. Planos Integrados Regionais: Relatórios das Unidades de Negócio da Diretoria Metropolitana (Centro; Norte; Sul; Leste; e Oeste) - 2006. v.2 a v.6. São Paulo: Diretoria Metropolitana - Sabesp, 2007.

SAMPA, HIROAKE. Utilization of effluent for the water resources of streams and toilet flushing in parks. Submission to the $3^{\text {rd }}$ World Water Forum (Japan - 2003). Nagoya, 2002. Disponível em: <http://210.169.251.146/html/for/en/spost.218_1597\% 7B0s=0\%7B9.html $>$ Acesso em 29/4/2007. 
SILVA, SONIA M. N. e. Uso Racional da Água. In TSUTIYA, MILTON T. (Org.) et al. Abastecimento de Água. $1^{a}$ ed. São Paulo: Departamento de Engenharia Hidráulica e Sanitária da Escola Politécnica da Universidade de São Paulo, 2004.

SUZUKI, YUTAKA et al. Large-area and on-site water reuse in Japan. $8^{\text {th }}$ International Conference on Wetland System for Water Pollution Control. Arusha, 2002. Disponível em <www.pwri.go.jp/eng/kokusai/conference/suzuki-yutaka 020327.pdf> Acesso em 29/4/2007.

TARDELLI FILHO, JAIRO. Controle e Redução de Perdas. In TSUTIYA, MILTON T. (Org.) et al. Abastecimento de Água. $1^{\underline{a}}$ ed. São Paulo: Departamento de Engenharia Hidráulica e Sanitária da Escola Politécnica da Universidade de São Paulo, 2004.

TATE, DONALD M. Principles of Water Use Efficiency. International Seminar on Efficient Water Use. Mexico, 1991. Disponível em <http://www.unesco.org.uy/phi/ hidros/efficient_water/wcap2.html> Acesso em: abril de 2007.

THAME, ANTÔNIO C. M. (Org.) et al. A Cobrança pelo Uso da Água. São Paulo: Instituto de Qualificação e Editoração Ltda., 2000.

THORNTON, JULIAN. Water loss control manual. $1^{\text {st }}$ ed. Hightstown: McGraw-Hill Professional, 2002.

THORNTON, JULIAN et al. How low can you go?: A practical approach to pressure control in low pressure systems. Leakage 2005 Specialized Conference - Conference Proceedings. Halifax: IWA, 2005.

THORNTON, JULIAN; LAMBERT, A. O. Progress in practical prediction of pressure: leakage, pressure: burst frequency and pressure: consumption relationships. Leakage 2005 Specialized Conference - Conference Proceedings. Halifax: IWA, 2005.

TSUTIYA, MILTON T. (Org.) et al. Abastecimento de Água. 1 a ed. São Paulo: Departamento de Engenharia Hidráulica e Sanitária da Escola Politécnica da Universidade de São Paulo, 2004.

USEPA - UNITED STATES ENVIRONMENT PROTECTION AGENCY. How to conserve water and use it effectively: a narrow-to-wide focus on water conservation. Disponível em <http://www.epa.gov/nps/chap3.html> Acesso em abril de 2007.

VAN DER KLEIJ, F. Maximising the Impact of Pressure Management. Global Leakage Summit 2007. Conference Proceedings. London: British Water, 2007. 
WALLACE, LYNN P. (Coord.). Water and Revenue Losses: Unaccounted-for Water. Denver: AWWARF / AWWA, 1987.

WRAS - Water Regulation Advisory Scheme (UK). Conservation of Water: An Information guidance note for architects, designers, installers and occupiers of premises. London: WRAS, 2005. Disponível em <http://wras.co.uk/PDF_Files/ IGN\%209-02-03\%20Water \%20Conservation\%20lssue\%202.pdf> Acesso em: maio de 2007.

WRc / WSA / WCA. Engineering and Operations Committee. Managing Leakage UK Water Industry Managing Leakage Report G: Managing Water Pressure. Swindon: WRc plc, 1994. 


\section{BIBLIOGRAFIA CONSULTADA}

ALEGRE, HELENA et al. Highlights of the IWA system of performance indicators for water supply services. IWA, 2002.

ALEGRE, HELENA et al. Performance Indicators for Water Supply Services. IWA Publishing, 2000.

AMERICAN WATER WORKS ASSOCIATION - AWWA. Water Meters - Selection, Installation, Testing, and Maintenance: Manual of Water Supply Practices - M6, $4^{\text {th }}$ ed. Denver: AWWA, 1999.

FARLEY, MALCOLM. Leakage Management and Control: A best practice training manual. Geneva: World Health Organization, 2001.

IWA - LEAKAGE 2005 - SPECIALIZED CONFERENCE. Conference Proceedings. Halifax: IWA, 2005.

IWA - LEMESOS 2002 - CONFERENCE. Leakage Management: A Practical Approach - Conference Proceedings. Lemesos: Water Board of Lemesos - Cyprus / IWA, 2002.

LAMBERT, A. O. et al. Leaks Suite PressCalcs Standard Software documents. United Kingdom, 2005.

MANCUSO, P.C.S.; SANTOS, H. F. dos. Reúso de Água - São Paulo: Manole, 2003.

OFWAT - Office of Water Services - England and Wales. Meeting the demand for water. London: UK NAO - National Audit Office, 2007. Disponível em <www.nao.org.uk/publications/nao_reports/06-07/0607150.pdf> Acesso em abril de 2007.

PNCDA - Programa Naional de Combate ao Desperdício de Água. DTA - Documento Técnico de Apoio no D3 - Micromedição. Brasília: Ministério das Cidades, 2004. Disponível em < http://www.cidades.gov.br/pncda/dtas/arq/dta_d3.pdf> Acesso em abril, 2007.

SABESP - MPO. Relatório: Redução de Controle de Perdas na RMSP. São Paulo: Sabesp, 2000. 
WALDRON, TIM (Coord.). Managing and Reducing Losses from Water Distribution Systems. 10 volumes. Hervey Bay: State of Queensland Environmental Protection Agency and Wide Bay Water, 2002.

WATER AUTHORITIES / WRc. Leakage Control Policy and Practice - Report 26. London: WRc, 1985.

WRc - Water Research Centre. Best practice principles in the calculation of the economic level of leakage calculation - Report UC3914A. WRc Plc, 2002. 


\section{GLOSSÁRIO}

adutora - tubulação, geralmente de grande diâmetro, utilizada para o transporte de água a reservatórios.

água bruta - água captada em manancial, no seu estado natural.

água tratada - água que já passou por processo de tratamento.

área testemunha - área, localizada próxima às áreas com pressão de distribuição controlada por VRP, que não está sob influência de VRP.

área de VRP - área cuja pressão de distribuição é controlada por VRP.

arrebentado - ponto de rede de distribuição que sofreu rompimento.

balanço hídrico - quadro, baseado no modelo proposto pela IWA, onde se procura mostrar, com base em dados obtidos através de medições e estimativas, o volume anual de água entregue para distribuição, o volume anual de usos da água distribuída, o volume anual perdido e os componentes das perdas de água; abordagem também conhecida por "top-down".

booster - equipamento instalado na rede de distribuição para aumentar a pressão da água para atender áreas elevadas ou mais distantes; o mesmo que sistema de bombeamento.

"bottom-up" - termo, em inglês, que significa "de baixo para cima", utilizado para definir a abordagem proposta pela IWA para cálculo dos diversos componentes do balanço hídrico, em que o volume de perdas reais é calculado a partir de testes de vazão mínima noturna, chegando-se aos outros componentes pela diferença entre os volumes de usos conhecidos: subtrai-se o volume de perdas reais do volume de perdas totais, resultando o volume de perdas aparentes.

"box plot" - método estatístico utilizado para descrição de uma série de dados e para a identificação de outiliers.

captação - ponto em manancial utilizado para a coleta de água para o sistema de abastecimento.

coeficiente do dia de maior consumo - coeficiente de variação de vazão que, aplicado à vazão média diária anual de um sistema de abastecimento de água, define a vazão média diária do dia de maior consumo. 
coeficiente da hora de maior consumo - coeficiente de variação de vazão que, aplicado à vazão média diária anual de um sistema de abastecimento de água, define a vazão da hora de maior consumo do dia.

coeficiente da hora de menor consumo - coeficiente de variação de vazão que, aplicado à vazão média diária anual de um sistema de abastecimento de água, define a vazão da hora de menor consumo do dia.

consumo autorizado - volume de água tratada consumido nas ligações ativas ou fornecido no atacado ou através de carros-tanque.

consumo autorizado não-cobrado - volume de consumo autorizado referente aos usos próprios e operacionais e aos volumes de usos especiais (sociais, operacionais, emergenciais e públicos).

economia - unidade de consumo dos serviços de saneamento; pode ser residencial, industrial, comercial ou pública; no caso de edifícios com diversos pavimentos e de alguns condomínios, uma única ligação abastece mais de uma economia.

estação elevatória - acessório das redes de adução e de distribuição onde são instaladas bombas para o recalque de água.

filtro - ferramenta da Planilha Eletrônica Excel, que permite a busca e o agrupamento de dados com determinada característica, podendo removê-los da base de dados em análise ou analisá-los separadamente dos demais dados.

Força-Tarefa para Redução de Perdas - (em inglês: "Water-Loss Task Force") grupo de trabalho, formado no âmbito da IWA, para disseminação e desenvolvimento de estudos que levem às "melhores práticas em operação de água", visando as ações para redução de perdas.

hidrômetro - medidor utilizado para se registrar o consumo de água.

hidrometração - característica do sistema de distribuição de água que diz respeito à medição dos consumos dos clientes através do uso de hidrômetros.

infra-estrutura de distribuição de água - compreende todos os equipamentos necessários à distribuição de água tratada aos consumidores: reservatórios, tubulações, válvulas, conexões e bombas, que constituem a rede de distribuição, e as ligações de água; no sentido usual, diz respeito às tubulações: redes e ramais.

layer (camada ou nível de dados, teme) - "conceito lógico para distinguir subdivisões de grupos de dados em um mapa digital. É o plano de informação que compõe a base de dados cartográficos de um SIG. Refere-se a dados que têm características semelhantes e que estão contidos em um mesmo grupo de informação". (MARCELLINI, 2002).

ligação ou ligação de água - dispositivo do sistema de distribuição de água, que faz a conexão entre a rede de distribuição e o imóvel do consumidor; compreende o 
ramal, o cavalete e o hidrômetro; muitas vezes é utilizado como sinônimo de ramal, que é a tubulação que faz a ligação entre a rede de distribuição de água e o hidrômetro do consumidor.

ligação ativa - conexão de água, em pleno funcionamento, que contribui para o faturamento da companhia de distribuição de água, no período considerado.

ligação inativa - ligação de água que consta como desativada, no sistema comercial da companhia que opera sistema de distribuição de água e não contribui para o faturamento, no período considerado.

macromedidor - medidor de vazão de água, instalado em pontos estratégicos da rede de adução, com a finalidade de controlar os volumes que circulam no sistema adutor de água tratada, os volumes captados e produzidos pelas estações de tratamento de água (ETAs), bem como os volumes entregues ao sistema de distribuição.

manancial - fonte natural de água (poços, rios ou reservatórios).

micromedição - sistema de medidores de vazão (hidrômetros) que controlam os volumes fornecidos aos consumidores (residenciais, comerciais, industriais e públicos).

micromedidor - o mesmo que hidrômetro.

nível de hidrometração - porcentagem do número de hidrômetros instalados, em relação ao número total de ligações ativas.

nível de significância (a) - "a significância estatística de um resultado é uma medida estimada do grau em que este resultado é verdadeiro" (UFSC, 2003); quanto menor a, maior a confiabilidade dos resultados; nos testes estatísticos do presente trabalho, foram utilizados níveis de significância de 5\% e de 1\%.

número de economias - número de domicílios/estabelecimentos abastecidos pela companhia de distribuição de água.

número de ligações - número de hidrômetros instalados nos consumidores pela companhia de distribuição de água.

outilier - termo utilizado em estatística para nomear pontos extremos e não usuais em uma série de dados.

perdas aparentes - anteriormente chamadas de perdas não-físicas, são também conhecidas como perdas comerciais; representam a parcela de água que foi utilizada, mas que não foi cobrada do consumidor (decorrente de: falhas no sistema de cobrança; submedição nos hidrômetros; ligações não-autorizadas; furtos de água em instalações da rede de abastecimento).

perdas reais - anteriormente, chamadas de perdas físicas, representam as perdas de água do sistema de abastecimento decorrentes de vazamentos na infra-estrutura 
de distribuição e/ou de extravasamentos em reservatórios (a água não foi utilizada, contrariamente ao que ocorre no caso das perdas aparentes).

perdas totais - diferença entre o volume total de água entregue para distribuição e o volume total de consumo autorizado.

"pizza" - gráfico, em formato circular, cujos setores representam as parcelas percentuais que compõem o todo.

pressão dinâmica - pressão, referida ao nível do eixo da via pública, em determinado ponto da rede, sob condição de consumo não nulo (definição: NBR 12218/1994).

pressão estática - pressão, referida ao nível do eixo da via pública, em determinado ponto da rede, sob condição de consumo nulo (definição: NBR 12218/1994).

ramal - parte da ligação de água entre a rede de distribuição e o cavalete (estrutura tubular onde é instalado o hidrômetro).

reabilitação de redes - conjunto de medidas que visam restituir à rede de distribuição sua capacidade de utilização; qualquer intervenção física que prolongue a vida da rede de distribuição e que envolva uma modificação da sua condição ou especificação (IWA).

renovação da infra-estrutura de distribuição - reabilitação de redes e substituição de ramais.

setor de abastecimento - área da rede de distribuição de água confinada por limites estanques e permanentes, alimentada por um ou mais pontos de entrada de água.

setorização - intervenções na rede de distribuição de água, visando o fechamento, através da instalação de trechos de tubulação e válvulas, de determinado trecho da rede, formando um setor de abastecimento com uma faixa de pressão de distribuição adequada.

sistema adutor - conjunto de tubulações (adutoras) e peças especiais (válvulas, conexões e bombas) destinado a conduzir a água produzida nas estações de tratamento aos reservatórios de distribuição.

submedição - volume não registrado pelos hidrômetros, decorrente da passagem de vazões abaixo da vazão mínima de precisão de leitura do hidrômetro (ocorre, principalmente pelo uso de caixas d'água ou por dimensionamento de hidrômetro incompatível com o perfil de consumo do imóvel).

substituição de rede - troca de uma rede existente por outra nova, com a finalidade de restaurar ou ampliar sua capacidade de vazão ou para reparar problemas estruturais na tubulação (fissura; corrosão; etc.). 
t-Student - é uma distribuição de probabilidade estatística simétrica, campaniforme e semelhante à curva normal padrão, porém com caudas mais largas, ou seja, uma simulação da t de Student pode gerar valores mais extremos que uma simulação da normal (definição: Wikipedia < http://pt.wikipedia.org/>).

tabela dinâmica - ferramenta da Planilha Eletrônica Excel, que permite elaborar relatórios "para resumir, analisar, explorar e apresentar dados de resumo" (Ajuda do Excel).

teste de calibração - ensaio realizado nos medidores de vazão, com a finalidade de manter o sistema de medição dentro de um padrão de exatidão considerado adequado.

testes de hipóteses - método estatístico que permite avaliar ou comparar amostras de populações (dados estatísticos).

"top-down" - tipo de abordagem para a determinação dos volumes de usos da água entregue à distribuição e os volumes de perdas, necessários à elaboração do quadro de balanço hídrico, em que se parte do volume entregue (corrigidos os erros de macromedição) e vão se descontando os volumes de usos conhecidos e sendo feitas estimativas dos volumes de perdas aparentes, para se chegar ao volume de perdas reais.

torneira de bóia - também chamada de bóia, é um dispositivo que regula a entrada de água em reservatórios domiciliares, mantendo a água em um nível constante.

transdutor de pressão - equipamento utilizado para conversão de uma unidade de pressão para um sinal digital (definição: INMETRO).

trilho - ferramenta do sistema Signos, equivalente à ferramenta "trace" de outros sistemas semelhantes; permite traçar uma área, ou polígono, recuperando-se informações georreferenciadas às áreas, ou polígonos, traçados.

usos emergenciais - consumo de água nas operações de treinamento e combate a incêndio e através do fornecimento de carros-tanque para abastecimento de emergência.

usos operacionais - consumo de água em operações especiais no sistema de abastecimento, como lavagem de reservatórios, desinfecção de rede de água e lavagem de rede coletora de esgotos.

usos sociais - consumo em áreas de submoradias (favelas, áreas invadidas e cortiços).

Válvula Redutora de Pressão (VRP) - equipamento instalado na entrada de determinada área de rede de distribuição, com o objetivo de reduzir a pressão nesse trecho de rede a níveis mais adequados.

VRP automática - válvula redutora de pressão com controle automático de saída de pressão. 
VRP fixa - válvula redutora de pressão com saída fixa de pressão.

vazamento inerente - vazamento não-visível, que não é passível de detecção com a tecnologia conhecida atualmente.

vazamento não-visível - vazamento que ainda não aflorou; localizável somente com o auxílio de equipamentos de detecção acústica de vazamentos.

vazamento visível - vazamento que já aflorou; detectável a olho nu.

volume efetivamente consumido - o mesmo que consumo efetivo: volume real de água tratada consumida pelo cliente; compreende o volume micromedido mais o volume devido à submedição no hidrômetro.

volume entregue à distribuição - volume transportado pelo sistema adutor aos reservatórios de distribuição, ou para abastecimento direto nos casos de derivação em marcha (quando trechos da rede de distribuição são ligados diretamente a adutoras).

volume medido (ou micromedido) - volume de consumo registrado nos hidrômetros.

zona de pressão - área estanque, da rede de distribuição, com limites permanentes, submetida a pressões definidas a partir das fontes principais de alimentação do setor (reservatório ou adutora), que geralmente adquire as denominações de Zona Baixa, Zona Alta, Zona Média ou zona abastecida por derivação direta do sistema adutor (derivação em marcha); área abrangida por uma subdivisão da rede, na qual as pressões estática e dinâmica obedecem a limites prefixados (definição: NBR 12218/1994). 


\section{APÊNDICE A: TOTALIZAÇÕES DE CONSUMO}

(*) Valores de Consumo em $\mathrm{m}^{3} / \mathrm{mês} /$ ligação

Tabela 1: Totalização dos dados de consumo: Áreas de VRP e testemunha

\begin{tabular}{|c|c|c|}
\hline ÁREA & Valores & Total \\
\hline \multirow[t]{8}{*}{ C1 } & Número de RGls & 1.039 \\
\hline & Número de Economias & 4.614 \\
\hline & Média de v1 & 71,2 \\
\hline & Média de v2 & 71,7 \\
\hline & Média de v3 & 69,4 \\
\hline & Média de v4 & 68,0 \\
\hline & Média de Média 6 Meses Anteriores & 70,7 \\
\hline & Média de Média v2, v3 e v4 & 69,7 \\
\hline \multirow[t]{8}{*}{ C1 (Testem.) } & Número de RGls & 1.662 \\
\hline & Número de Economias & 3.458 \\
\hline & Média de v1 & 36,6 \\
\hline & Média de v2 & 38,2 \\
\hline & Média de v3 & 34,6 \\
\hline & Média de v4 & 37,6 \\
\hline & Média de Média 6 Meses Anteriores & 36,1 \\
\hline & Média de Média v2, v3 e v4 & 36,8 \\
\hline \multirow[t]{8}{*}{ C2 } & Número de RGls & 287 \\
\hline & Número de Economias & 510 \\
\hline & Média de v1 & 33,4 \\
\hline & Média de v2 & 34,0 \\
\hline & Média de v3 & 32,8 \\
\hline & Média de v4 & 33,8 \\
\hline & Média de Média 6 Meses Anteriores & 34,1 \\
\hline & Média de Média v2, v3 e v4 & 33,5 \\
\hline \multirow[t]{8}{*}{ C2 (Testem.) } & Número de RGls & 47 \\
\hline & Número de Economias & 368 \\
\hline & Média de v1 & 82,2 \\
\hline & Média de v2 & 90,6 \\
\hline & Média de v3 & 85,0 \\
\hline & Média de v4 & 88,8 \\
\hline & Média de Média 6 Meses Anteriores & 88,0 \\
\hline & Média de Média v2, v3 e v4 & 88,1 \\
\hline \multirow[t]{8}{*}{ C3 } & Número de RGls & 711 \\
\hline & Número de Economias & 1.518 \\
\hline & Média de v1 & 32,3 \\
\hline & Média de v2 & 34,1 \\
\hline & Média de v3 & 31,7 \\
\hline & Média de v4 & 32,5 \\
\hline & Média de Média 6 Meses Anteriores & 33,4 \\
\hline & Média de Média v2, v3 e v4 & 32,8 \\
\hline
\end{tabular}


(continuação)

\begin{tabular}{|c|c|c|}
\hline \multirow[t]{8}{*}{ C3 (Testem.) } & Número de RGls & 43 \\
\hline & Número de Economias & 130 \\
\hline & Média de v1 & 49,3 \\
\hline & Média de v2 & 50,5 \\
\hline & Média de v3 & 61,7 \\
\hline & Média de v4 & 61,6 \\
\hline & Média de Média 6 Meses Anteriores & 52,8 \\
\hline & Média de Média v2, v3 e v4 & 57,9 \\
\hline \multirow[t]{8}{*}{ C4 } & Número de RGls & 422 \\
\hline & Número de Economias & 637 \\
\hline & Média de v1 & 24,7 \\
\hline & Média de v2 & 27,9 \\
\hline & Média de v3 & 25,9 \\
\hline & Média de v4 & 25,4 \\
\hline & Média de Média 6 Meses Anteriores & 26,7 \\
\hline & Média de Média v2, v3 e v4 & 26,4 \\
\hline \multirow[t]{8}{*}{ C4 (Testem.) } & Número de RGls & 182 \\
\hline & Número de Economias & 344 \\
\hline & Média de v1 & 27,8 \\
\hline & Média de v2 & 29,6 \\
\hline & Média de v3 & 27,7 \\
\hline & Média de v4 & 29,8 \\
\hline & Média de Média 6 Meses Anteriores & 30,0 \\
\hline & Média de Média v2, v3 e v4 & 29,0 \\
\hline \multirow[t]{8}{*}{ C5 } & Número de RGls & 4.127 \\
\hline & Número de Economias & 5.790 \\
\hline & Média de v1 & 17,6 \\
\hline & Média de v2 & 17,4 \\
\hline & Média de v3 & 17,4 \\
\hline & Média de v4 & 18,7 \\
\hline & Média de Média 6 Meses Anteriores & 16,8 \\
\hline & Média de Média v2, v3 e v4 & 17,8 \\
\hline \multirow[t]{8}{*}{ C5 (Testem.) } & Número de RGls & 1.275 \\
\hline & Número de Economias & 1.730 \\
\hline & Média de v1 & 18,8 \\
\hline & Média de v2 & 17,3 \\
\hline & Média de v3 & 17,6 \\
\hline & Média de v4 & 17,9 \\
\hline & Média de Média 6 Meses Anteriores & 16,8 \\
\hline & Média de Média v2, v3 e v4 & 17,6 \\
\hline
\end{tabular}


(continuação)

\begin{tabular}{|c|c|c|}
\hline \multirow[t]{8}{*}{ C6 } & Número de RGls & 1.836 \\
\hline & Número de Economias & 2.559 \\
\hline & Média de v1 & 16,6 \\
\hline & Média de v2 & 16,9 \\
\hline & Média de v3 & 16,7 \\
\hline & Média de v4 & 17,0 \\
\hline & Média de Média 6 Meses Anteriores & 16,3 \\
\hline & Média de Média v2, v3 e v4 & 16,9 \\
\hline \multirow[t]{8}{*}{ C6 (Testem.) } & Número de RGls & 1.588 \\
\hline & Número de Economias & 2.064 \\
\hline & Média de v1 & 16,5 \\
\hline & Média de v2 & 17,7 \\
\hline & Média de v3 & 17,4 \\
\hline & Média de v4 & 17,9 \\
\hline & Média de Média 6 Meses Anteriores & 16,6 \\
\hline & Média de Média v2, v3 e v4 & 17,6 \\
\hline \multirow[t]{8}{*}{ C7 } & Número de RGls & 1.077 \\
\hline & Número de Economias & 1.363 \\
\hline & Média de v1 & 19,0 \\
\hline & Média de v2 & 17,8 \\
\hline & Média de v3 & 20,0 \\
\hline & Média de v4 & 18,2 \\
\hline & Média de Média 6 Meses Anteriores & 18,8 \\
\hline & Média de Média v2, v3 e v4 & 18,7 \\
\hline \multirow[t]{8}{*}{ C7 (Testem.) } & Número de RGls & 448 \\
\hline & Número de Economias & 600 \\
\hline & Média de v1 & 19,8 \\
\hline & Média de v2 & 18,5 \\
\hline & Média de v3 & 19,7 \\
\hline & Média de v4 & 19,8 \\
\hline & Média de Média 6 Meses Anteriores & 19,3 \\
\hline & Média de Média v2, v3 e v4 & 19,3 \\
\hline \multirow[t]{8}{*}{ C8 } & Número de RGls & 95 \\
\hline & Número de Economias & 567 \\
\hline & Média de v1 & 133,1 \\
\hline & Média de v2 & 156,3 \\
\hline & Média de v3 & 130,5 \\
\hline & Média de v4 & 144,3 \\
\hline & Média de Média 6 Meses Anteriores & 148,5 \\
\hline & Média de Média v2, v3 e v4 & 143,7 \\
\hline
\end{tabular}


(continuação)

\begin{tabular}{|c|c|c|}
\hline \multirow[t]{8}{*}{ C8 (Testem.) } & Número de RGls & 171 \\
\hline & Número de Economias & 958 \\
\hline & Média de v1 & 75,1 \\
\hline & Média de v2 & 90,1 \\
\hline & Média de v3 & 75,8 \\
\hline & Média de v4 & 80,0 \\
\hline & Média de Média 6 Meses Anteriores & 83,5 \\
\hline & Média de Média v2, v3 e v4 & 82,0 \\
\hline \multirow[t]{8}{*}{ C9 } & Número de RGls & 1.554 \\
\hline & Número de Economias & 4.130 \\
\hline & Média de v1 & 46,9 \\
\hline & Média de v2 & 42,9 \\
\hline & Média de v3 & 44,7 \\
\hline & Média de v4 & 41,2 \\
\hline & Média de Média 6 Meses Anteriores & 43,6 \\
\hline & Média de Média v2, v3 e v4 & 42,9 \\
\hline \multirow[t]{8}{*}{ C9 (Testem.) } & Número de RGls & 904 \\
\hline & Número de Economias & 1.902 \\
\hline & Média de v1 & 41,5 \\
\hline & Média de v2 & 37,9 \\
\hline & Média de v3 & 40,3 \\
\hline & Média de v4 & 37,7 \\
\hline & Média de Média 6 Meses Anteriores & 38,9 \\
\hline & Média de Média v2, v3 e v4 & 38,6 \\
\hline \multirow[t]{8}{*}{ C10 } & Número de RGls & 101 \\
\hline & Número de Economias & 919 \\
\hline & Média de v1 & 197,4 \\
\hline & Média de v2 & 185,8 \\
\hline & Média de v3 & 219,1 \\
\hline & Média de v4 & 228,5 \\
\hline & Média de Média 6 Meses Anteriores & 186,4 \\
\hline & Média de Média v2, v3 e v4 & 211,1 \\
\hline \multirow[t]{8}{*}{ C10 (Testem.) } & Número de RGls & 112 \\
\hline & Número de Economias & 378 \\
\hline & Média de v1 & 61,8 \\
\hline & Média de v2 & 63,9 \\
\hline & Média de v3 & 61,6 \\
\hline & Média de v4 & 64,7 \\
\hline & Média de Média 6 Meses Anteriores & 58,8 \\
\hline & Média de Média v2, v3 e v4 & 63,4 \\
\hline
\end{tabular}


(continuação)

\begin{tabular}{|c|c|c|}
\hline \multirow[t]{8}{*}{ F1 } & Número de RGls & 658 \\
\hline & Número de Economias & 877 \\
\hline & Média de v1 & 14,9 \\
\hline & Média de v2 & 14,4 \\
\hline & Média de v3 & 16,5 \\
\hline & Média de v4 & 17,0 \\
\hline & Média de Média 6 Meses Anteriores & 15,8 \\
\hline & Média de Média v2, v3 e v4 & 16,0 \\
\hline \multirow[t]{8}{*}{ F1 (Testem.) } & Número de RGls & 423 \\
\hline & Número de Economias & 559 \\
\hline & Média de v1 & 15,1 \\
\hline & Média de v2 & 14,5 \\
\hline & Média de v3 & 16,3 \\
\hline & Média de v4 & 16,6 \\
\hline & Média de Média 6 Meses Anteriores & 15,9 \\
\hline & Média de Média v2, v3 e v4 & 15,8 \\
\hline \multirow[t]{8}{*}{ F2 } & Número de RGls & 424 \\
\hline & Número de Economias & 586 \\
\hline & Média de v1 & 17,8 \\
\hline & Média de v2 & 18,2 \\
\hline & Média de v3 & 18,6 \\
\hline & Média de v4 & 20,1 \\
\hline & Média de Média 6 Meses Anteriores & 20,3 \\
\hline & Média de Média v2, v3 e v4 & 19,0 \\
\hline \multirow[t]{8}{*}{ F2 (Testem.) } & Número de RGls & 374 \\
\hline & Número de Economias & 487 \\
\hline & Média de v1 & 16,4 \\
\hline & Média de v2 & 16,9 \\
\hline & Média de v3 & 17,8 \\
\hline & Média de v4 & 18,7 \\
\hline & Média de Média 6 Meses Anteriores & 18,5 \\
\hline & Média de Média v2, v3 e v4 & 17,8 \\
\hline \multirow[t]{8}{*}{ F3 } & Número de RGls & 35 \\
\hline & Número de Economias & 35 \\
\hline & Média de v1 & 17,1 \\
\hline & Média de v2 & 16,0 \\
\hline & Média de v3 & 18,5 \\
\hline & Média de v4 & 16,5 \\
\hline & Média de Média 6 Meses Anteriores & 17,3 \\
\hline & Média de Média v2, v3 e v4 & 17,0 \\
\hline
\end{tabular}


(continuação)

\begin{tabular}{llr}
\hline F3 (Testem.) & Número de RGls & 493 \\
& Número de Economias & 648 \\
& Média de v1 & 17,5 \\
& Média de v2 & 16,4 \\
& Média de v3 & 18,1 \\
& Média de v4 & 16,5 \\
& Média de Média 6 Meses Anteriores & 17,2 \\
& Média de Média v2, v3 e v4 & 17,0 \\
& Número de RGls & 327 \\
& Número de Economias & 401 \\
& Média de v1 & 19,8 \\
& Média de v2 & 16,9 \\
& Média de v3 & 18,4 \\
& Média de v4 & 16,0 \\
& Média de Média 6 Meses Anteriores & 18,9 \\
& Média de Média v2, v3 e v4 & 17,1 \\
& Número de RGls & 135 \\
& Número de Economias & 167 \\
& Média de v1 & 20,0 \\
& Média de v2 & 18,5 \\
& Média de v3 & 19,0 \\
& Média de v4 & 17,7 \\
& Média de Média 6 Meses Anteriores & 19,7 \\
& Média de Média v2, v3 e v4 & 18,4 \\
& Número de RGls & 287 \\
& Número de Economias & 346 \\
& Média de v1 & 30,8 \\
& Média de v2 & 31,8 \\
& Média de v3 & 26,4 \\
& Média de v4 & 26,6 \\
& Média de Média 6 Meses Anteriores & 30,1 \\
& Média de Média v2, v3 e v4 & 28,3 \\
& Número de RGls & 158 \\
& Número de Economias & 386 \\
& Média de v1 & 44,8 \\
& Média de v2 & 45,9 \\
& Média de v3 & 42,7 \\
& Média de v4 & 42,4 \\
& Média de Média 6 Meses Anteriores & 47,1 \\
& Média de Média v2, v3 e v4 & 43,6 \\
& & $(c o n t i n u a)$ \\
& & \\
\hline F5 (Testem.) & & \\
& & \\
& &
\end{tabular}


(continuação)

\begin{tabular}{|c|c|c|}
\hline \multirow[t]{8}{*}{ F6 } & Número de RGls & 62 \\
\hline & Número de Economias & 73 \\
\hline & Média de v1 & 15,4 \\
\hline & Média de v2 & 12,5 \\
\hline & Média de v3 & 13,9 \\
\hline & Média de v4 & 14,4 \\
\hline & Média de Média 6 Meses Anteriores & 14,4 \\
\hline & Média de Média v2, v3 e v4 & 13,6 \\
\hline \multirow[t]{8}{*}{ F6 (Testem.) } & Número de RGls & 272 \\
\hline & Número de Economias & 331 \\
\hline & Média de v1 & 14,1 \\
\hline & Média de v2 & 14,0 \\
\hline & Média de v3 & 14,8 \\
\hline & Média de v4 & 14,0 \\
\hline & Média de Média 6 Meses Anteriores & 15,4 \\
\hline & Média de Média v2, v3 e v4 & 14,3 \\
\hline \multirow[t]{8}{*}{ F7 } & Número de RGls & 634 \\
\hline & Número de Economias & 747 \\
\hline & Média de v1 & 17,1 \\
\hline & Média de v2 & 15,9 \\
\hline & Média de v3 & 18,0 \\
\hline & Média de v4 & 18,6 \\
\hline & Média de Média 6 Meses Anteriores & 18,9 \\
\hline & Média de Média v2, v3 e v4 & 17,5 \\
\hline \multirow[t]{8}{*}{ F7 (Testem.) } & Número de RGls & 440 \\
\hline & Número de Economias & 502 \\
\hline & Média de v1 & 17,7 \\
\hline & Média de v2 & 17,1 \\
\hline & Média de v3 & 18,6 \\
\hline & Média de v4 & 19,5 \\
\hline & Média de Média 6 Meses Anteriores & 19,7 \\
\hline & Média de Média v2, v3 e v4 & 18,4 \\
\hline \multirow[t]{8}{*}{ F8 } & Número de RGls & 121 \\
\hline & Número de Economias & 128 \\
\hline & Média de v1 & 26,0 \\
\hline & Média de v2 & 26,6 \\
\hline & Média de v3 & 26,5 \\
\hline & Média de v4 & 26,0 \\
\hline & Média de Média 6 Meses Anteriores & 26,1 \\
\hline & Média de Média v2, v3 e v4 & 26,3 \\
\hline
\end{tabular}


(continuação)

\begin{tabular}{|c|c|c|}
\hline \multirow[t]{8}{*}{ F8 (Testem.) } & Número de RGls & 537 \\
\hline & Número de Economias & 636 \\
\hline & Média de v1 & 22,5 \\
\hline & Média de v2 & 22,5 \\
\hline & Média de v3 & 21,8 \\
\hline & Média de v4 & 21,7 \\
\hline & Média de Média 6 Meses Anteriores & 22,6 \\
\hline & Média de Média v2, v3 e v4 & 22,0 \\
\hline \multirow[t]{8}{*}{ F9 } & Número de RGls & 350 \\
\hline & Número de Economias & 409 \\
\hline & Média de v1 & 23,1 \\
\hline & Média de v2 & 22,0 \\
\hline & Média de v3 & 23,8 \\
\hline & Média de v4 & 21,0 \\
\hline & Média de Média 6 Meses Anteriores & 24,7 \\
\hline & Média de Média v2, v3 e v4 & 22,3 \\
\hline \multirow[t]{8}{*}{ F9 (Testem.) } & Número de RGls & 186 \\
\hline & Número de Economias & 196 \\
\hline & Média de v1 & 22,6 \\
\hline & Média de v2 & 20,5 \\
\hline & Média de v3 & 23,3 \\
\hline & Média de v4 & 21,4 \\
\hline & Média de Média 6 Meses Anteriores & 22,2 \\
\hline & Média de Média v2, v3 e v4 & 21,7 \\
\hline \multirow[t]{8}{*}{ F10 } & Número de RGls & 483 \\
\hline & Número de Economias & 585 \\
\hline & Média de v1 & 46,2 \\
\hline & Média de v2 & 46,6 \\
\hline & Média de v3 & 42,7 \\
\hline & Média de v4 & 40,9 \\
\hline & Média de Média 6 Meses Anteriores & 43,9 \\
\hline & Média de Média v2, v3 e v4 & 43,4 \\
\hline \multirow[t]{8}{*}{ F10 (Testem.) } & Número de RGls & 686 \\
\hline & Número de Economias & 1.201 \\
\hline & Média de v1 & 44,4 \\
\hline & Média de v2 & 45,9 \\
\hline & Média de v3 & 40,9 \\
\hline & Média de v4 & 39,6 \\
\hline & Média de Média 6 Meses Anteriores & 43,6 \\
\hline & Média de Média v2, v3 e v4 & 42,1 \\
\hline
\end{tabular}


(continuação)

\begin{tabular}{|c|c|c|}
\hline \multirow[t]{8}{*}{ F11 } & Número de RGls & 89 \\
\hline & Número de Economias & 116 \\
\hline & Média de v1 & 15,4 \\
\hline & Média de v2 & 13,7 \\
\hline & Média de v3 & 16,3 \\
\hline & Média de v4 & 16,9 \\
\hline & Média de Média 6 Meses Anteriores & 16,8 \\
\hline & Média de Média v2, v3 e v4 & 15,6 \\
\hline \multirow[t]{8}{*}{ F11 (Testem.) } & Número de RGls & 61 \\
\hline & Número de Economias & 73 \\
\hline & Média de v1 & 13,1 \\
\hline & Média de v2 & 11,9 \\
\hline & Média de v3 & 14,6 \\
\hline & Média de v4 & 14,6 \\
\hline & Média de Média 6 Meses Anteriores & 14,5 \\
\hline & Média de Média v2, v3 e v4 & 13,7 \\
\hline \multirow[t]{8}{*}{ F12 } & Número de RGls & 430 \\
\hline & Número de Economias & 530 \\
\hline & Média de v1 & 15,9 \\
\hline & Média de v2 & 16,8 \\
\hline & Média de v3 & 19,0 \\
\hline & Média de v4 & 21,1 \\
\hline & Média de Média 6 Meses Anteriores & 18,8 \\
\hline & Média de Média v2, v3 e v4 & 18,9 \\
\hline \multirow[t]{8}{*}{ F12 (Testem.) } & Número de RGls & 540 \\
\hline & Número de Economias & 814 \\
\hline & Média de v1 & 18,9 \\
\hline & Média de v2 & 19,2 \\
\hline & Média de v3 & 21,9 \\
\hline & Média de v4 & 21,8 \\
\hline & Média de Média 6 Meses Anteriores & 22,6 \\
\hline & Média de Média v2, v3 e v4 & 21,0 \\
\hline \multirow[t]{8}{*}{ F13 } & Número de RGls & 554 \\
\hline & Número de Economias & 797 \\
\hline & Média de v1 & 22,1 \\
\hline & Média de v2 & 24,5 \\
\hline & Média de v3 & 22,4 \\
\hline & Média de v4 & 23,3 \\
\hline & Média de Média 6 Meses Anteriores & 22,9 \\
\hline & Média de Média v2, v3 e v4 & 23,4 \\
\hline
\end{tabular}


(continuação)

\begin{tabular}{|c|c|c|}
\hline \multirow[t]{8}{*}{ F13 (Testem.) } & Número de RGls & 36 \\
\hline & Número de Economias & 142 \\
\hline & Média de v1 & 50,9 \\
\hline & Média de v2 & 51,1 \\
\hline & Média de v3 & 55,3 \\
\hline & Média de v4 & 51,5 \\
\hline & Média de Média 6 Meses Anteriores & 54,2 \\
\hline & Média de Média v2, v3 e v4 & 52,6 \\
\hline \multirow[t]{8}{*}{ F14 } & Número de RGls & 231 \\
\hline & Número de Economias & 297 \\
\hline & Média de v1 & 22,1 \\
\hline & Média de v2 & 21,1 \\
\hline & Média de v3 & 21,3 \\
\hline & Média de v4 & 19,8 \\
\hline & Média de Média 6 Meses Anteriores & 20,3 \\
\hline & Média de Média v2, v3 e v4 & 20,8 \\
\hline \multirow[t]{8}{*}{ F14 (Testem.) } & Número de RGls & 35 \\
\hline & Número de Economias & 109 \\
\hline & Média de v1 & 55,4 \\
\hline & Média de v2 & 52,7 \\
\hline & Média de v3 & 50,6 \\
\hline & Média de v4 & 47,4 \\
\hline & Média de Média 6 Meses Anteriores & 48,5 \\
\hline & Média de Média v2, v3 e v4 & 50,2 \\
\hline \multirow[t]{8}{*}{ F15 } & Número de RGls & 223 \\
\hline & Número de Economias & 408 \\
\hline & Média de v1 & 21,0 \\
\hline & Média de v2 & 21,8 \\
\hline & Média de v3 & 22,4 \\
\hline & Média de v4 & 22,7 \\
\hline & Média de Média 6 Meses Anteriores & 20,1 \\
\hline & Média de Média v2, v3 e v4 & 22,3 \\
\hline \multirow[t]{8}{*}{ F15 (Testem.) } & Número de RGls & 360 \\
\hline & Número de Economias & 392 \\
\hline & Média de v1 & 13,5 \\
\hline & Média de v2 & 13,7 \\
\hline & Média de v3 & 14,0 \\
\hline & Média de v4 & 14,7 \\
\hline & Média de Média 6 Meses Anteriores & 13,0 \\
\hline & Média de Média v2, v3 e v4 & 14,1 \\
\hline
\end{tabular}


(continuação)

\begin{tabular}{llr}
\hline F16 & Número de RGls & 15 \\
& Número de Economias & 16 \\
& Média de v1 & 14,3 \\
& Média de v2 & 13,4 \\
& Média de v3 & 14,3 \\
& Média de v4 & 16,3 \\
& Média de Média 6 Meses Anteriores & 16,3 \\
& Média de Média v2, v3 e v4 & 14,7 \\
F16 (Testem.) & Número de RGls & 251 \\
& Número de Economias & 327 \\
& Média de v1 & 15,1 \\
& Média de v2 & 14,6 \\
& Média de v3 & 16,6 \\
& Média de v4 & 13,5 \\
& Média de Média 6 Meses Anteriores & 16,3 \\
& Média de Média v2, v3 e v4 & 14,9 \\
& Número de RGls & 221 \\
& Número de Economias & 269 \\
& Média de v1 & 13,4 \\
& Média de v2 & 13,2 \\
& Média de v3 & 14,9 \\
& Média de v4 & 14,6 \\
& Média de Média 6 Meses Anteriores & 14,7 \\
& Média de Média v2, v3 e v4 & 14,2 \\
& Número de RGls & 422 \\
& Número de Economias & 509 \\
& Média de v1 & 12,8 \\
& Média de v2 & 13,4 \\
& Média de v3 & 14,2 \\
& Média de v4 & 14,4 \\
& Consumo Médio nos 6 Meses Anteriores & 14,3 \\
& Média do Consumo v2, v3 e v4 & 14,0 \\
\hline F17 (Testem. &
\end{tabular}


Dessa Tabela 1, foram geradas as seguintes totalizações:

- Conjunto das Áreas de VRP e Testemunha:

Total Número de RGls

Total Número de Economias

Total Média de v1

Total Média de v2

Total Média de v3

Total Média de v4

Total Consumo Médio nos 6 Meses Anteriores

Total Média dos Consumos v2, v3 e v4

- Conjunto das áreas de VRP:

Total Número de RGls

16.393

Total Número de Economias

29.227

Total Média de v1

27,9

Total Média de v2

27,7

Total Média de v3

27,8

Total Média de v4

27,8

Total Consumo Médio nos 6 Meses Anteriores

27,7

Total Média dos Consumos v2, v3 e v4

27,8

- Conjunto das áreas Testemunha:

Total Número de RGls

Total Número de Economias

Total Média de $\mathbf{v} 1$

Total Média de v2

Total Média de v3

Total Média de v4

Total Consumo Médio nos 6 Meses Anteriores

25,9

Total Média de Consumo v2, v3 e v4 
Tabela 2: Totalização dos dados de consumo: Áreas de VRP c/ saída fixa

\begin{tabular}{|c|c|c|}
\hline AREA & Valores & Total \\
\hline \multirow[t]{8}{*}{ F1 } & Número de RGls & 658 \\
\hline & Número de Economias & 877 \\
\hline & Média de v1 & 14,9 \\
\hline & Média de v2 & 14,4 \\
\hline & Média de v3 & 16,5 \\
\hline & Média de v4 & 17,0 \\
\hline & Consumo Médio nos 6 Meses Anteriores & 15,8 \\
\hline & Média de Consumo Posterior (v2, v3 e v4) & 16,0 \\
\hline \multirow[t]{8}{*}{ F2 } & Número de RGls & 424 \\
\hline & Número de Economias & 586 \\
\hline & Média de v1 & 17,8 \\
\hline & Média de v2 & 18,2 \\
\hline & Média de v3 & 18,6 \\
\hline & Média de v4 & 20,1 \\
\hline & Consumo Médio nos 6 Meses Anteriores & 20,3 \\
\hline & Média de Consumo Posterior (v2, v3 e v4) & 19,0 \\
\hline \multirow[t]{8}{*}{ F3 } & Número de RGls & 35 \\
\hline & Número de Economias & 35 \\
\hline & Média de v1 & 17,1 \\
\hline & Média de v2 & 16,0 \\
\hline & Média de v3 & 18,5 \\
\hline & Média de v4 & 16,5 \\
\hline & Consumo Médio nos 6 Meses Anteriores & 17,3 \\
\hline & Média de Consumo Posterior (v2, v3 e v4) & 17,0 \\
\hline \multirow[t]{8}{*}{ F4 } & Número de RGls & 327 \\
\hline & Número de Economias & 401 \\
\hline & Média de v1 & 19,8 \\
\hline & Média de v2 & 16,9 \\
\hline & Média de v3 & 18,4 \\
\hline & Média de v4 & 16,0 \\
\hline & Consumo Médio nos 6 Meses Anteriores & 18,9 \\
\hline & Média de Consumo Posterior (v2, v3 e v4) & 17,1 \\
\hline \multirow[t]{8}{*}{ F5 } & Número de RGls & 287 \\
\hline & Número de Economias & 346 \\
\hline & Média de v1 & 30,8 \\
\hline & Média de v2 & 31,8 \\
\hline & Média de v3 & 26,4 \\
\hline & Média de v4 & 26,6 \\
\hline & Consumo Médio nos 6 Meses Anteriores & 30,1 \\
\hline & Média de Consumo Posterior (v2, v3 e v4) & 28,3 \\
\hline
\end{tabular}


(continuação)

\begin{tabular}{|c|c|c|}
\hline \multirow[t]{8}{*}{ F6 } & Número de RGls & 62 \\
\hline & Número de Economias & 73 \\
\hline & Média de v1 & 15,4 \\
\hline & Média de v2 & 12,5 \\
\hline & Média de v3 & 13,9 \\
\hline & Média de v4 & 14,4 \\
\hline & Consumo Médio nos 6 Meses Anteriores & 14,4 \\
\hline & Média de Consumo Posterior (v2, v3 e v4) & 13,6 \\
\hline \multirow[t]{8}{*}{ F7 } & Número de RGls & 634 \\
\hline & Número de Economias & 747 \\
\hline & Média de v1 & 17,1 \\
\hline & Média de v2 & 15,9 \\
\hline & Média de v3 & 18,0 \\
\hline & Média de v4 & 18,6 \\
\hline & Consumo Médio nos 6 Meses Anteriores & 18,9 \\
\hline & Média de Consumo Posterior (v2, v3 e v4) & 17,5 \\
\hline \multirow[t]{8}{*}{ F8 } & Número de RGls & 121 \\
\hline & Número de Economias & 128 \\
\hline & Média de v1 & 26,0 \\
\hline & Média de v2 & 26,6 \\
\hline & Média de v3 & 26,5 \\
\hline & Média de v4 & 26,0 \\
\hline & Consumo Médio nos 6 Meses Anteriores & 26,1 \\
\hline & Média de Consumo Posterior (v2, v3 e v4) & 26,3 \\
\hline \multirow[t]{8}{*}{ F9 } & Número de RGls & 350 \\
\hline & Número de Economias & 409 \\
\hline & Média de v1 & 23,1 \\
\hline & Média de v2 & 22,0 \\
\hline & Média de v3 & 23,8 \\
\hline & Média de v4 & 21,0 \\
\hline & Consumo Médio nos 6 Meses Anteriores & 24,7 \\
\hline & Média de Consumo Posterior (v2, v3 e v4) & 22,3 \\
\hline \multirow[t]{8}{*}{ F10 } & Número de RGls & 483 \\
\hline & Número de Economias & 585 \\
\hline & Média de v1 & 46,2 \\
\hline & Média de v2 & 46,6 \\
\hline & Média de v3 & 42,7 \\
\hline & Média de v4 & 40,9 \\
\hline & Consumo Médio nos 6 Meses Anteriores & 43,9 \\
\hline & Média de Consumo Posterior (v2, v3 e v4) & 43,4 \\
\hline
\end{tabular}


(continuação)

\begin{tabular}{|c|c|c|}
\hline \multirow[t]{8}{*}{ F11 } & Número de RGls & 89 \\
\hline & Número de Economias & 116 \\
\hline & Média de v1 & 15,4 \\
\hline & Média de v2 & 13,7 \\
\hline & Média de v3 & 16,3 \\
\hline & Média de v4 & 16,9 \\
\hline & Consumo Médio nos 6 Meses Anteriores & 16,8 \\
\hline & Média de Consumo Posterior (v2, v3 e v4) & 15,6 \\
\hline \multirow[t]{8}{*}{ F12 } & Número de RGls & 430 \\
\hline & Número de Economias & 530 \\
\hline & Média de v1 & 15,9 \\
\hline & Média de v2 & 16,8 \\
\hline & Média de v3 & 19,0 \\
\hline & Média de v4 & 21,1 \\
\hline & Consumo Médio nos 6 Meses Anteriores & 18,8 \\
\hline & Média de Consumo Posterior (v2, v3 e v4) & 18,9 \\
\hline \multirow[t]{8}{*}{ F13 } & Número de RGls & 554 \\
\hline & Número de Economias & 797 \\
\hline & Média de v1 & 22,1 \\
\hline & Média de v2 & 24,5 \\
\hline & Média de v3 & 22,4 \\
\hline & Média de v4 & 23,3 \\
\hline & Consumo Médio nos 6 Meses Anteriores & 22,9 \\
\hline & Média de Consumo Posterior (v2, v3 e v4) & 23,4 \\
\hline \multirow[t]{8}{*}{ F14 } & Número de RGls & 231 \\
\hline & Número de Economias & 297 \\
\hline & Média de v1 & 22,1 \\
\hline & Média de v2 & 21,1 \\
\hline & Média de v3 & 21,3 \\
\hline & Média de v4 & 19,8 \\
\hline & Consumo Médio nos 6 Meses Anteriores & 20,3 \\
\hline & Média de Consumo Posterior (v2, v3 e v4) & 20,8 \\
\hline \multirow[t]{8}{*}{ F15 } & Número de RGls & 223 \\
\hline & Número de Economias & 408 \\
\hline & Média de v1 & 21,0 \\
\hline & Média de v2 & 21,8 \\
\hline & Média de v3 & 22,4 \\
\hline & Média de v4 & 22,7 \\
\hline & Consumo Médio nos 6 Meses Anteriores & 20,1 \\
\hline & Média de Consumo Posterior (v2, v3 e v4) & 22,3 \\
\hline
\end{tabular}


(continuação)

\begin{tabular}{llr}
\hline F16 & Número de RGls & 15 \\
& Número de Economias & 16 \\
& Média de v1 & 14,3 \\
& Média de v2 & 13,4 \\
& Média de v3 & 14,3 \\
& Média de v4 & 16,3 \\
& Consumo Médio nos 6 Meses Anteriores & 16,3 \\
& Média de Consumo Posterior (v2, v3 e v4) & 14,7 \\
& Número de RGls & 221 \\
& Número de Economias & 269 \\
F17 & Média de v1 & 13,4 \\
& Média de v2 & 13,2 \\
& Média de v3 & 14,9 \\
& Média de v4 & 14,6 \\
& Consumo Médio nos 6 Meses Anteriores & 14,7 \\
& Média de Consumo Posterior (v2, v3 e v4) & 14,2 \\
\hline Total Número de RGls & $\mathbf{5 . 1 4 4}$ \\
Total Número de Economias & $\mathbf{6 . 6 2 0}$ \\
Total Média de v1 & $\mathbf{2 1 , 8}$ \\
Total Média de v2 & $\mathbf{2 1 , 7}$ \\
Total Média de v3 & $\mathbf{2 1 , 9}$ \\
Total Média de v4 & $\mathbf{2 1 , 9}$ \\
Total Consumo Médio nos 6 Meses Anteriores & $\mathbf{2 2 , 4}$ \\
Total Média de Consumo Posterior (v2, v3 e v4) & $\mathbf{2 1 , 8}$
\end{tabular}


Tabela 2.1: Totalização de consumo: Áreas VRP FIXA (até 12 econ./Lig.)

\begin{tabular}{|c|c|c|}
\hline AREA & Valores & Total \\
\hline \multirow[t]{8}{*}{ F1 } & Número de RGls & 658 \\
\hline & Número de Economias & 877 \\
\hline & Média de v1 & 14,9 \\
\hline & Média de v2 & 14,4 \\
\hline & Média de v3 & 16,5 \\
\hline & Média de v4 & 17,0 \\
\hline & Consumo Médio nos 6 Meses Anteriores & 15,8 \\
\hline & Média de Consumo Posterior (v2, v3 e v4) & 16,0 \\
\hline \multirow[t]{8}{*}{ F2 } & Número de RGls & 423 \\
\hline & Número de Economias & 546 \\
\hline & Média de v1 & 17,8 \\
\hline & Média de v2 & 18,2 \\
\hline & Média de v3 & 18,6 \\
\hline & Média de v4 & 20,0 \\
\hline & Consumo Médio nos 6 Meses Anteriores & 20,2 \\
\hline & Média de Consumo Posterior (v2, v3 e v4) & 18,9 \\
\hline \multirow[t]{8}{*}{ F3 } & Número de RGls & 35 \\
\hline & Número de Economias & 35 \\
\hline & Média de v1 & 17,1 \\
\hline & Média de v2 & 16,0 \\
\hline & Média de v3 & 18,5 \\
\hline & Média de v4 & 16,5 \\
\hline & Consumo Médio nos 6 Meses Anteriores & 17,3 \\
\hline & Média de Consumo Posterior (v2, v3 e v4) & 17,0 \\
\hline \multirow[t]{8}{*}{ F4 } & Número de RGls & 327 \\
\hline & Número de Economias & 401 \\
\hline & Média de v1 & 19,8 \\
\hline & Média de v2 & 16,9 \\
\hline & Média de v3 & 18,4 \\
\hline & Média de v4 & 16,0 \\
\hline & Consumo Médio nos 6 Meses Anteriores & 18,9 \\
\hline & Média de Consumo Posterior (v2, v3 e v4) & 17,1 \\
\hline \multirow[t]{8}{*}{ F5 } & Número de RGls & 285 \\
\hline & Número de Economias & 292 \\
\hline & Média de v1 & 27,1 \\
\hline & Média de v2 & 28,5 \\
\hline & Média de v3 & 23,4 \\
\hline & Média de v4 & 23,7 \\
\hline & Consumo Médio nos 6 Meses Anteriores & 26,6 \\
\hline & Média de Consumo Posterior (v2, v3 e v4) & 25,2 \\
\hline
\end{tabular}


(continuação)

\begin{tabular}{|c|c|c|}
\hline \multirow[t]{8}{*}{ F6 } & Número de RGls & 62 \\
\hline & Número de Economias & 73 \\
\hline & Média de v1 & 15,4 \\
\hline & Média de v2 & 12,5 \\
\hline & Média de v3 & 13,9 \\
\hline & Média de v4 & 14,4 \\
\hline & Consumo Médio nos 6 Meses Anteriores & 14,4 \\
\hline & Média de Consumo Posterior (v2, v3 e v4) & 13,6 \\
\hline \multirow[t]{8}{*}{ F7 } & Número de RGls & 634 \\
\hline & Número de Economias & 747 \\
\hline & Média de v1 & 17,1 \\
\hline & Média de v2 & 15,9 \\
\hline & Média de v3 & 18,0 \\
\hline & Média de v4 & 18,6 \\
\hline & Consumo Médio nos 6 Meses Anteriores & 18,9 \\
\hline & Média de Consumo Posterior (v2, v3 e v4) & 17,5 \\
\hline \multirow[t]{8}{*}{ F8 } & Número de RGls & 121 \\
\hline & Número de Economias & 128 \\
\hline & Média de v1 & 26,0 \\
\hline & Média de v2 & 26,6 \\
\hline & Média de v3 & 26,5 \\
\hline & Média de v4 & 26,0 \\
\hline & Consumo Médio nos 6 Meses Anteriores & 26,1 \\
\hline & Média de Consumo Posterior (v2, v3 e v4) & 26,3 \\
\hline \multirow[t]{8}{*}{ F9 } & Número de RGls & 349 \\
\hline & Número de Economias & 394 \\
\hline & Média de v1 & 22,4 \\
\hline & Média de v2 & 21,5 \\
\hline & Média de v3 & 23,2 \\
\hline & Média de v4 & 20,3 \\
\hline & Consumo Médio nos 6 Meses Anteriores & 24,1 \\
\hline & Média de Consumo Posterior (v2, v3 e v4) & 21,6 \\
\hline \multirow[t]{8}{*}{ F10 } & Número de RGls & 480 \\
\hline & Número de Economias & 521 \\
\hline & Média de v1 & 40,4 \\
\hline & Média de v2 & 40,7 \\
\hline & Média de v3 & 36,1 \\
\hline & Média de v4 & 34,2 \\
\hline & Consumo Médio nos 6 Meses Anteriores & 38,5 \\
\hline & Média de Consumo Posterior (v2, v3 e v4) & 37,0 \\
\hline
\end{tabular}


(continuação)

\begin{tabular}{|c|c|c|}
\hline \multirow[t]{8}{*}{ F11 } & Número de RGls & 89 \\
\hline & Número de Economias & 116 \\
\hline & Média de v1 & 15,4 \\
\hline & Média de v2 & 13,7 \\
\hline & Média de v3 & 16,3 \\
\hline & Média de v4 & 16,9 \\
\hline & Consumo Médio nos 6 Meses Anteriores & 16,8 \\
\hline & Média de Consumo Posterior (v2, v3 e v4) & 15,6 \\
\hline \multirow[t]{8}{*}{ F12 } & Número de RGls & 429 \\
\hline & Número de Economias & 493 \\
\hline & Média de v1 & 15,9 \\
\hline & Média de v2 & 16,8 \\
\hline & Média de v3 & 19,0 \\
\hline & Média de v4 & 21,0 \\
\hline & Consumo Médio nos 6 Meses Anteriores & 18,8 \\
\hline & Média de Consumo Posterior (v2, v3 e v4) & 18,9 \\
\hline \multirow[t]{8}{*}{ F13 } & Número de RGls & 554 \\
\hline & Número de Economias & 797 \\
\hline & Média de v1 & 22,1 \\
\hline & Média de v2 & 24,5 \\
\hline & Média de v3 & 22,4 \\
\hline & Média de v4 & 23,3 \\
\hline & Consumo Médio nos 6 Meses Anteriores & 22,9 \\
\hline & Média de Consumo Posterior (v2, v3 e v4) & 23,4 \\
\hline \multirow[t]{8}{*}{ F14 } & Número de RGls & 231 \\
\hline & Número de Economias & 297 \\
\hline & Média de v1 & 22,1 \\
\hline & Média de v2 & 21,1 \\
\hline & Média de v3 & 21,3 \\
\hline & Média de v4 & 19,8 \\
\hline & Consumo Médio nos 6 Meses Anteriores & 20,3 \\
\hline & Média de Consumo Posterior (v2, v3 e v4) & 20,8 \\
\hline \multirow[t]{8}{*}{ F15 } & Número de RGls & 218 \\
\hline & Número de Economias & 248 \\
\hline & Média de v1 & 14,3 \\
\hline & Média de v2 & 15,4 \\
\hline & Média de v3 & 15,2 \\
\hline & Média de v4 & 15,2 \\
\hline & Consumo Médio nos 6 Meses Anteriores & 13,5 \\
\hline & Média de Consumo Posterior (v2, v3 e v4) & 15,3 \\
\hline
\end{tabular}


(continuação)

\begin{tabular}{llr}
\hline F16 & Número de RGls & 15 \\
& Número de Economias & 16 \\
& Média de v1 & 14,3 \\
& Média de v2 & 13,4 \\
& Média de v3 & 14,3 \\
& Média de v4 & 16,3 \\
& Consumo Médio nos 6 Meses Anteriores & 16,3 \\
& Média de Consumo Posterior (v2, v3 e v4) & 14,7 \\
& Número de RGls & 221 \\
& Número de Economias & 269 \\
F17 & Média de v1 & 13,4 \\
& Média de v2 & 13,2 \\
& Média de v3 & 14,9 \\
& Média de v4 & 14,6 \\
& Consumo Médio nos 6 Meses Anteriores & 14,7 \\
& Média de Consumo Posterior (v2, v3 e v4) & 14,2 \\
\hline Total Número de RGls & $\mathbf{5 . 1 3 1}$ \\
Total Número de Economias & $\mathbf{6 . 2 5 0}$ \\
Total Média de v1 & $\mathbf{2 0 , 7}$ \\
Total Média de v2 & $\mathbf{2 0 , 6}$ \\
Total Média de v3 & $\mathbf{2 0 , 8}$ \\
Total Média de v4 & $\mathbf{2 0 , 7}$ \\
Total Consumo Médio nos 6 Meses Anteriores & $\mathbf{2 1 , 4}$ \\
Total Média de Consumo Posterior (v2, v3 e v4) & $\mathbf{2 0 , 7}$
\end{tabular}


Tabela 2.2: Totalização de consumo: Áreas VRP FIXA (até 3 econ./Lig.)

\begin{tabular}{|c|c|c|}
\hline ÁREA & Valores & Total \\
\hline \multirow[t]{8}{*}{ F1 } & Número de RGls & 652 \\
\hline & Número de Economias & 853 \\
\hline & Média de v1 & 14,7 \\
\hline & Média de v2 & 14,2 \\
\hline & Média de v3 & 16,3 \\
\hline & Média de v4 & 16,8 \\
\hline & Consumo Médio nos 6 Meses Anteriores & 15,6 \\
\hline & Média de Consumo Posterior (v2, v3 e v4) & 15,8 \\
\hline \multirow[t]{8}{*}{ F2 } & Número de RGls & 416 \\
\hline & Número de Economias & 508 \\
\hline & Média de v1 & 17,1 \\
\hline & Média de v2 & 17,6 \\
\hline & Média de v3 & 17,8 \\
\hline & Média de v4 & 19,2 \\
\hline & Consumo Médio nos 6 Meses Anteriores & 19,5 \\
\hline & Média de Consumo Posterior (v2, v3 e v4) & 18,2 \\
\hline \multirow[t]{8}{*}{ F3 } & Número de RGls & 35 \\
\hline & Número de Economias & 35 \\
\hline & Média de v1 & 17,1 \\
\hline & Média de v2 & 16,0 \\
\hline & Média de v3 & 18,5 \\
\hline & Média de v4 & 16,5 \\
\hline & Consumo Médio nos 6 Meses Anteriores & 17,3 \\
\hline & Média de Consumo Posterior (v2, v3 e v4) & 17,0 \\
\hline \multirow[t]{8}{*}{ F4 } & Número de RGls & 324 \\
\hline & Número de Economias & 382 \\
\hline & Média de v1 & 19,2 \\
\hline & Média de v2 & 16,3 \\
\hline & Média de v3 & 17,9 \\
\hline & Média de v4 & 15,6 \\
\hline & Consumo Médio nos 6 Meses Anteriores & 18,3 \\
\hline & Média de Consumo Posterior (v2, v3 e v4) & 16,6 \\
\hline \multirow[t]{8}{*}{ F5 } & Número de RGls & 285 \\
\hline & Número de Economias & 292 \\
\hline & Média de v1 & 27,1 \\
\hline & Média de v2 & 28,5 \\
\hline & Média de v3 & 23,4 \\
\hline & Média de v4 & 23,7 \\
\hline & Consumo Médio nos 6 Meses Anteriores & 26,6 \\
\hline & Média de Consumo Posterior (v2, v3 e v4) & 25,2 \\
\hline
\end{tabular}


(continuação)

\begin{tabular}{|c|c|c|}
\hline \multirow[t]{8}{*}{ F6 } & Número de RGls & 62 \\
\hline & Número de Economias & 73 \\
\hline & Média de v1 & 15,4 \\
\hline & Média de v2 & 12,5 \\
\hline & Média de v3 & 13,9 \\
\hline & Média de v4 & 14,4 \\
\hline & Consumo Médio nos 6 Meses Anteriores & 14,4 \\
\hline & Média de Consumo Posterior (v2, v3 e v4) & 13,6 \\
\hline \multirow[t]{8}{*}{ F7 } & Número de RGls & 629 \\
\hline & Número de Economias & 721 \\
\hline & Média de v1 & 16,9 \\
\hline & Média de v2 & 15,8 \\
\hline & Média de v3 & 17,7 \\
\hline & Média de v4 & 18,2 \\
\hline & Consumo Médio nos 6 Meses Anteriores & 18,7 \\
\hline & Média de Consumo Posterior (v2, v3 e v4) & 17,2 \\
\hline \multirow[t]{8}{*}{ F8 } & Número de RGls & 120 \\
\hline & Número de Economias & 124 \\
\hline & Média de v1 & 26,1 \\
\hline & Média de v2 & 26,7 \\
\hline & Média de v3 & 26,5 \\
\hline & Média de v4 & 26,1 \\
\hline & Consumo Médio nos 6 Meses Anteriores & 26,2 \\
\hline & Média de Consumo Posterior (v2, v3 e v4) & 26,4 \\
\hline \multirow[t]{8}{*}{ F9 } & Número de RGls & 347 \\
\hline & Número de Economias & 385 \\
\hline & Média de v1 & 22,3 \\
\hline & Média de v2 & 21,4 \\
\hline & Média de v3 & 23,1 \\
\hline & Média de v4 & 20,3 \\
\hline & Consumo Médio nos 6 Meses Anteriores & 24,1 \\
\hline & Média de Consumo Posterior (v2, v3 e v4) & 21,6 \\
\hline \multirow[t]{8}{*}{ F10 } & Número de RGls & 477 \\
\hline & Número de Economias & 490 \\
\hline & Média de v1 & 38,0 \\
\hline & Média de v2 & 38,7 \\
\hline & Média de v3 & 34,2 \\
\hline & Média de v4 & 32,2 \\
\hline & Consumo Médio nos 6 Meses Anteriores & 36,5 \\
\hline & Média de Consumo Posterior (v2, v3 e v4) & 35,1 \\
\hline
\end{tabular}


(continuação)

\begin{tabular}{|c|c|c|}
\hline \multirow[t]{8}{*}{ F11 } & Número de RGls & 88 \\
\hline & Número de Economias & 112 \\
\hline & Média de v1 & 15,2 \\
\hline & Média de v2 & 13,4 \\
\hline & Média de v3 & 16,0 \\
\hline & Média de v4 & 16,6 \\
\hline & Consumo Médio nos 6 Meses Anteriores & 16,5 \\
\hline & Média de Consumo Posterior (v2, v3 e v4) & 15,3 \\
\hline \multirow[t]{8}{*}{ F12 } & Número de RGls & 427 \\
\hline & Número de Economias & 476 \\
\hline & Média de v1 & 15,6 \\
\hline & Média de v2 & 16,2 \\
\hline & Média de v3 & 18,7 \\
\hline & Média de v4 & 20,9 \\
\hline & Consumo Médio nos 6 Meses Anteriores & 18,5 \\
\hline & Média de Consumo Posterior (v2, v3 e v4) & 18,6 \\
\hline \multirow[t]{8}{*}{ F13 } & Número de RGls & 544 \\
\hline & Número de Economias & 752 \\
\hline & Média de v1 & 20,9 \\
\hline & Média de v2 & 23,3 \\
\hline & Média de v3 & 21,2 \\
\hline & Média de v4 & 22,0 \\
\hline & Consumo Médio nos 6 Meses Anteriores & 21,8 \\
\hline & Média de Consumo Posterior (v2, v3 e v4) & 22,2 \\
\hline \multirow[t]{8}{*}{ F14 } & Número de RGls & 226 \\
\hline & Número de Economias & 275 \\
\hline & Média de v1 & 21,8 \\
\hline & Média de v2 & 20,9 \\
\hline & Média de v3 & 21,0 \\
\hline & Média de v4 & 19,4 \\
\hline & Consumo Médio nos 6 Meses Anteriores & 20,0 \\
\hline & Média de Consumo Posterior (v2, v3 e v4) & 20,4 \\
\hline \multirow[t]{8}{*}{ F15 } & Número de RGls & 218 \\
\hline & Número de Economias & 248 \\
\hline & Média de v1 & 14,3 \\
\hline & Média de v2 & 15,4 \\
\hline & Média de v3 & 15,2 \\
\hline & Média de v4 & 15,2 \\
\hline & Consumo Médio nos 6 Meses Anteriores & 13,5 \\
\hline & Média de Consumo Posterior (v2, v3 e v4) & 15,3 \\
\hline
\end{tabular}


(continuação)

\begin{tabular}{llr}
\hline F16 & Número de RGls & 15 \\
& Número de Economias & 16 \\
& Média de v1 & 14,3 \\
& Média de v2 & 13,4 \\
& Média de v3 & 14,3 \\
& Média de v4 & 16,3 \\
& Consumo Médio nos 6 Meses Anteriores & 16,3 \\
& Média de Consumo Posterior (v2, v3 e v4) & 14,7 \\
& Número de RGls & 221 \\
& Número de Economias & 269 \\
F17 & Média de v1 & 13,4 \\
& Média de v2 & 13,2 \\
& Média de v3 & 14,9 \\
& Média de v4 & 14,6 \\
& Consumo Médio nos 6 Meses Anteriores & 14,7 \\
& Média de Consumo Posterior (v2, v3 e v4) & 14,2 \\
\hline Total Número de RGls & $\mathbf{5 . 0 8 6}$ \\
Total Número de Economias & $\mathbf{6 . 0 1 1}$ \\
Total Média de v1 & $\mathbf{2 0 , 1}$ \\
Total Média de v2 & $\mathbf{2 0 , 1}$ \\
Total Média de v3 & $\mathbf{2 0 , 3}$ \\
Total Média de v4 & $\mathbf{2 0 , 2}$ \\
Total Consumo Médio nos 6 Meses Anteriores & $\mathbf{2 0 , 9}$ \\
Total Média de Consumo Posterior (v2, v3 e v4) & $\mathbf{2 0 , 2}$
\end{tabular}


Tabela 2.3: Totalização de consumo: Áreas VRP FIXA (1 econ./Lig.)

\begin{tabular}{|c|c|c|}
\hline ÁREA & Valores & Total \\
\hline \multirow[t]{8}{*}{ F1 } & Número de RGls & 482 \\
\hline & Número de Economias & 482 \\
\hline & Média de v1 & 13,0 \\
\hline & Média de v2 & 12,7 \\
\hline & Média de v3 & 14,5 \\
\hline & Média de v4 & 15,1 \\
\hline & Consumo Médio nos 6 Meses Anteriores & 13,9 \\
\hline & Média de Consumo Posterior (v2, v3 e v4) & 14,1 \\
\hline \multirow[t]{8}{*}{ F2 } & Número de RGls & 336 \\
\hline & Número de Economias & 336 \\
\hline & Média de v1 & 16,0 \\
\hline & Média de v2 & 16,3 \\
\hline & Média de v3 & 16,3 \\
\hline & Média de v4 & 17,6 \\
\hline & Consumo Médio nos 6 Meses Anteriores & 18,0 \\
\hline & Média de Consumo Posterior (v2, v3 e v4) & 16,7 \\
\hline \multirow[t]{8}{*}{ F3 } & Número de RGls & 35 \\
\hline & Número de Economias & 35 \\
\hline & Média de v1 & 17,1 \\
\hline & Média de v2 & 16,0 \\
\hline & Média de v3 & 18,5 \\
\hline & Média de v4 & 16,5 \\
\hline & Consumo Médio nos 6 Meses Anteriores & 17,3 \\
\hline & Média de Consumo Posterior (v2, v3 e v4) & 17,0 \\
\hline \multirow[t]{8}{*}{ F4 } & Número de RGls & 273 \\
\hline & Número de Economias & 273 \\
\hline & Média de v1 & 18,1 \\
\hline & Média de v2 & 15,5 \\
\hline & Média de v3 & 16,5 \\
\hline & Média de v4 & 14,5 \\
\hline & Consumo Médio nos 6 Meses Anteriores & 17,1 \\
\hline & Média de Consumo Posterior (v2, v3 e v4) & 15,5 \\
\hline \multirow[t]{8}{*}{ F5 } & Número de RGls & 279 \\
\hline & Número de Economias & 279 \\
\hline & Média de v1 & 27,0 \\
\hline & Média de v2 & 28,2 \\
\hline & Média de v3 & 23,3 \\
\hline & Média de v4 & 23,6 \\
\hline & Consumo Médio nos 6 Meses Anteriores & 26,4 \\
\hline & Média de Consumo Posterior (v2, v3 e v4) & 25,0 \\
\hline
\end{tabular}


(continuação)

\begin{tabular}{|c|c|c|}
\hline \multirow[t]{8}{*}{ F6 } & Número de RGls & 51 \\
\hline & Número de Economias & 51 \\
\hline & Média de v1 & 14,7 \\
\hline & Média de v2 & 12,1 \\
\hline & Média de v3 & 13,3 \\
\hline & Média de v4 & 13,8 \\
\hline & Consumo Médio nos 6 Meses Anteriores & 13,8 \\
\hline & Média de Consumo Posterior (v2, v3 e v4) & 13,1 \\
\hline \multirow[t]{8}{*}{ F7 } & Número de RGls & 553 \\
\hline & Número de Economias & 553 \\
\hline & Média de v1 & 16,0 \\
\hline & Média de v2 & 15,0 \\
\hline & Média de v3 & 16,9 \\
\hline & Média de v4 & 17,5 \\
\hline & Consumo Médio nos 6 Meses Anteriores & 17,8 \\
\hline & Média de Consumo Posterior (v2, v3 e v4) & 16,5 \\
\hline \multirow[t]{8}{*}{ F8 } & Número de RGls & 116 \\
\hline & Número de Economias & 116 \\
\hline & Média de v1 & 25,8 \\
\hline & Média de v2 & 26,2 \\
\hline & Média de v3 & 26,4 \\
\hline & Média de v4 & 26,1 \\
\hline & Consumo Médio nos 6 Meses Anteriores & 26,0 \\
\hline & Média de Consumo Posterior (v2, v3 e v4) & 26,2 \\
\hline \multirow[t]{8}{*}{ F9 } & Número de RGls & 313 \\
\hline & Número de Economias & 313 \\
\hline & Média de v1 & 22,4 \\
\hline & Média de v2 & 21,7 \\
\hline & Média de v3 & 23,1 \\
\hline & Média de v4 & 20,0 \\
\hline & Consumo Médio nos 6 Meses Anteriores & 24,3 \\
\hline & Média de Consumo Posterior (v2, v3 e v4) & 21,6 \\
\hline \multirow[t]{8}{*}{ F10 } & Número de RGls & 465 \\
\hline & Número de Economias & 465 \\
\hline & Média de v1 & 37,8 \\
\hline & Média de v2 & 38,9 \\
\hline & Média de v3 & 34,0 \\
\hline & Média de v4 & 32,0 \\
\hline & Consumo Médio nos 6 Meses Anteriores & 36,4 \\
\hline & Média de Consumo Posterior (v2, v3 e v4) & 35,0 \\
\hline
\end{tabular}


(continuação)

\begin{tabular}{|c|c|c|}
\hline \multirow[t]{8}{*}{ F11 } & Número de RGls & 65 \\
\hline & Número de Economias & 65 \\
\hline & Média de v1 & 13,3 \\
\hline & Média de v2 & 11,8 \\
\hline & Média de v3 & 14,4 \\
\hline & Média de v4 & 14,5 \\
\hline & Consumo Médio nos 6 Meses Anteriores & 14,6 \\
\hline & Média de Consumo Posterior (v2, v3 e v4) & 13,6 \\
\hline \multirow{8}{*}{ F12 } & Número de RGls & 386 \\
\hline & Número de Economias & 386 \\
\hline & Média de v1 & 14,7 \\
\hline & Média de v2 & 15,1 \\
\hline & Média de v3 & 17,9 \\
\hline & Média de v4 & 20,1 \\
\hline & Consumo Médio nos 6 Meses Anteriores & 17,4 \\
\hline & Média de Consumo Posterior (v2, v3 e v4) & 17,7 \\
\hline \multirow{8}{*}{ F13 } & Número de RGls & 365 \\
\hline & Número de Economias & 365 \\
\hline & Média de v1 & 18,9 \\
\hline & Média de v2 & 21,1 \\
\hline & Média de v3 & 19,2 \\
\hline & Média de v4 & 20,0 \\
\hline & Consumo Médio nos 6 Meses Anteriores & 19,8 \\
\hline & Média de Consumo Posterior (v2, v3 e v4) & 20,1 \\
\hline \multirow[t]{8}{*}{ F14 } & Número de RGls & 180 \\
\hline & Número de Economias & 180 \\
\hline & Média de v1 & 21,3 \\
\hline & Média de v2 & 20,3 \\
\hline & Média de v3 & 20,4 \\
\hline & Média de v4 & 18,8 \\
\hline & Consumo Médio nos 6 Meses Anteriores & 19,5 \\
\hline & Média de Consumo Posterior (v2, v3 e v4) & 19,8 \\
\hline \multirow[t]{8}{*}{ F15 } & Número de RGls & 189 \\
\hline & Número de Economias & 189 \\
\hline & Média de v1 & 13,6 \\
\hline & Média de v2 & 14,7 \\
\hline & Média de v3 & 14,4 \\
\hline & Média de v4 & 14,2 \\
\hline & Consumo Médio nos 6 Meses Anteriores & 12,8 \\
\hline & Média de Consumo Posterior (v2, v3 e v4) & 14,4 \\
\hline
\end{tabular}


(continuação)

\begin{tabular}{llr}
\hline F16 & Número de RGls & 14 \\
& Número de Economias & 14 \\
& Média de v1 & 14,2 \\
& Média de v2 & 12,8 \\
& Média de v3 & 13,4 \\
& Média de v4 & 15,6 \\
& Consumo Médio nos 6 Meses Anteriores & 15,0 \\
& Média de Consumo Posterior (v2, v3 e v4) & 13,9 \\
& Número de RGls & 176 \\
& Número de Economias & 176 \\
F17 & Média de v1 & 13,1 \\
& Média de v2 & 12,7 \\
& Média de v3 & 13,7 \\
& Média de v4 & 13,5 \\
& Consumo Médio nos 6 Meses Anteriores & 13,9 \\
& Média de Consumo Posterior (v2, v3 e v4) & 13,3 \\
\hline Total Número de RGls & $\mathbf{4 . 2 7 8}$ \\
Total Número de Economias & $\mathbf{4 . 2 7 8}$ \\
Total Média de v1 & $\mathbf{1 9 , 7}$ \\
Total Média de v2 & $\mathbf{1 9 , 7}$ \\
Total Média de v3 & $\mathbf{1 9 , 7}$ \\
Total Média de v4 & $\mathbf{1 9 , 5}$ \\
Total Consumo Médio nos 6 Meses Anteriores & $\mathbf{2 0 , 3}$ \\
Total Média de Consumo Posterior (v2, v3 e v4) & $\mathbf{1 9 , 6}$
\end{tabular}


Tabela 3: Totalização de consumo: Áreas de VRP c/ contr. autom. de pressão

\begin{tabular}{|c|c|c|}
\hline ÁREA & Valores & Total \\
\hline \multirow[t]{8}{*}{ C1 } & Número de RGls & 1.039 \\
\hline & Número de Economias & 4.614 \\
\hline & Média de v1 & 71,2 \\
\hline & Média de v2 & 71,7 \\
\hline & Média de v3 & 69,4 \\
\hline & Média de v4 & 68,0 \\
\hline & Consumo Médio nos 6 Meses Anteriores & 70,7 \\
\hline & Média de Consumo Posterior (v2, v3 e v4) & 69,7 \\
\hline \multirow[t]{8}{*}{ C2 } & Número de RGls & 287 \\
\hline & Número de Economias & 510 \\
\hline & Média de v1 & 33,4 \\
\hline & Média de v2 & 34,0 \\
\hline & Média de v3 & 32,8 \\
\hline & Média de v4 & 33,8 \\
\hline & Consumo Médio nos 6 Meses Anteriores & 34,1 \\
\hline & Média de Consumo Posterior (v2, v3 e v4) & 33,5 \\
\hline \multirow[t]{8}{*}{ C3 } & Número de RGls & 711 \\
\hline & Número de Economias & 1.518 \\
\hline & Média de v1 & 32,3 \\
\hline & Média de v2 & 34,1 \\
\hline & Média de v3 & 31,7 \\
\hline & Média de v4 & 32,5 \\
\hline & Consumo Médio nos 6 Meses Anteriores & 33,4 \\
\hline & Média de Consumo Posterior (v2, v3 e v4) & 32,8 \\
\hline \multirow[t]{8}{*}{ C4 } & Número de RGls & 422 \\
\hline & Número de Economias & 637 \\
\hline & Média de v1 & 24,7 \\
\hline & Média de v2 & 27,9 \\
\hline & Média de v3 & 25,9 \\
\hline & Média de v4 & 25,4 \\
\hline & Consumo Médio nos 6 Meses Anteriores & 26,7 \\
\hline & Média de Consumo Posterior (v2, v3 e v4) & 26,4 \\
\hline \multirow[t]{8}{*}{ C5 } & Número de RGls & 4.127 \\
\hline & Número de Economias & 5.790 \\
\hline & Média de v1 & 17,6 \\
\hline & Média de v2 & 17,4 \\
\hline & Média de v3 & 17,4 \\
\hline & Média de v4 & 18,7 \\
\hline & Consumo Médio nos 6 Meses Anteriores & 16,8 \\
\hline & Média de Consumo Posterior (v2, v3 e v4) & 17,8 \\
\hline
\end{tabular}


(continuação)

\begin{tabular}{|c|c|c|}
\hline \multirow[t]{8}{*}{ C6 } & Número de RGls & 1.836 \\
\hline & Número de Economias & 2.559 \\
\hline & Média de v1 & 16,6 \\
\hline & Média de v2 & 16,9 \\
\hline & Média de v3 & 16,7 \\
\hline & Média de v4 & 17,0 \\
\hline & Consumo Médio nos 6 Meses Anteriores & 16,3 \\
\hline & Média de Consumo Posterior (v2, v3 e v4) & 16,9 \\
\hline \multirow[t]{8}{*}{ C7 } & Número de RGls & 1.077 \\
\hline & Número de Economias & 1.363 \\
\hline & Média de v1 & 19,0 \\
\hline & Média de v2 & 17,8 \\
\hline & Média de v3 & 20,0 \\
\hline & Média de v4 & 18,2 \\
\hline & Consumo Médio nos 6 Meses Anteriores & 18,8 \\
\hline & Média de Consumo Posterior (v2, v3 e v4) & 18,7 \\
\hline \multirow[t]{8}{*}{ C8 } & Número de RGls & 95 \\
\hline & Número de Economias & 567 \\
\hline & Média de v1 & 133,1 \\
\hline & Média de v2 & 156,3 \\
\hline & Média de v3 & 130,5 \\
\hline & Média de v4 & 144,3 \\
\hline & Consumo Médio nos 6 Meses Anteriores & 148,5 \\
\hline & Média de Consumo Posterior (v2, v3 e v4) & 143,7 \\
\hline \multirow[t]{8}{*}{ C9 } & Número de RGls & 1.554 \\
\hline & Número de Economias & 4.130 \\
\hline & Média de v1 & 46,9 \\
\hline & Média de v2 & 42,9 \\
\hline & Média de v3 & 44,7 \\
\hline & Média de v4 & 41,2 \\
\hline & Consumo Médio nos 6 Meses Anteriores & 43,6 \\
\hline & Média de Consumo Posterior (v2, v3 e v4) & 42,9 \\
\hline
\end{tabular}


(continuação)

\begin{tabular}{llr}
\hline C10 & Número de RGls & 101 \\
& Número de Economias & 919 \\
& Média de v1 & 197,4 \\
& Média de v2 & 185,8 \\
& Média de v3 & 219,1 \\
& Média de v4 & 228,5 \\
& Consumo Médio nos 6 Meses Anteriores & 186,4 \\
& Média de Consumo Posterior (v2, v3 e v4) & 211,1 \\
\hline & $\mathbf{1 1 . 2 4 9}$ \\
Total Número de RGls & $\mathbf{2 2 . 6 0 7}$ \\
Total Número de Economias & $\mathbf{3 0 , 7}$ \\
Total Média de v1 & $\mathbf{3 0 , 5}$ \\
Total Média de v2 & $\mathbf{3 0 , 5}$ \\
Total Média de v3 & $\mathbf{3 0 , 5}$ \\
Total Média de v4 & $\mathbf{3 0 , 1}$ \\
Total Consumo Médio nos 6 Meses Anteriores & $\mathbf{3 0 , 5}$ \\
Total Média de Consumo Posterior (v2, v3 e v4)
\end{tabular}


Tabela 3.1: Totalização de consumo: Áreas de VRP Auto. (até 12 econ./Lig.)

\begin{tabular}{|c|c|c|}
\hline ÁREA & Valores & Total \\
\hline \multirow[t]{8}{*}{ C1 } & Número de RGls & 981 \\
\hline & Número de Economias & 1.644 \\
\hline & Média de v1 & 34,8 \\
\hline & Média de v2 & 36,1 \\
\hline & Média de v3 & 33,4 \\
\hline & Média de v4 & 31,7 \\
\hline & Consumo Médio nos 6 Meses Anteriores & 34,0 \\
\hline & Média de Consumo Posterior (v2, v3 e v4) & 33,7 \\
\hline \multirow[t]{8}{*}{ C2 } & Número de RGls & 284 \\
\hline & Número de Economias & 341 \\
\hline & Média de v1 & 22,6 \\
\hline & Média de v2 & 23,3 \\
\hline & Média de v3 & 22,7 \\
\hline & Média de v4 & 21,6 \\
\hline & Consumo Médio nos 6 Meses Anteriores & 23,3 \\
\hline & Média de Consumo Posterior (v2, v3 e v4) & 22,5 \\
\hline \multirow[t]{8}{*}{ C3 } & Número de RGls & 699 \\
\hline & Número de Economias & 1.312 \\
\hline & Média de v1 & 29,1 \\
\hline & Média de v2 & 30,8 \\
\hline & Média de v3 & 28,4 \\
\hline & Média de v4 & 29,3 \\
\hline & Consumo Médio nos 6 Meses Anteriores & 29,9 \\
\hline & Média de Consumo Posterior (v2, v3 e v4) & 29,5 \\
\hline \multirow[t]{8}{*}{ C4 } & Número de RGls & 422 \\
\hline & Número de Economias & 637 \\
\hline & Média de v1 & 24,7 \\
\hline & Média de v2 & 27,9 \\
\hline & Média de v3 & 25,9 \\
\hline & Média de v4 & 25,4 \\
\hline & Consumo Médio nos 6 Meses Anteriores & 26,7 \\
\hline & Média de Consumo Posterior (v2, v3 e v4) & 26,4 \\
\hline \multirow[t]{8}{*}{ C5 } & Número de RGls & 4.126 \\
\hline & Número de Economias & 5.650 \\
\hline & Média de v1 & 17,4 \\
\hline & Média de v2 & 17,3 \\
\hline & Média de v3 & 17,1 \\
\hline & Média de v4 & 18,2 \\
\hline & Consumo Médio nos 6 Meses Anteriores & 16,5 \\
\hline & Média de Consumo Posterior (v2, v3 e v4) & 17,5 \\
\hline
\end{tabular}


(continuação)

\begin{tabular}{|c|c|c|}
\hline \multirow[t]{8}{*}{ C6 } & Número de RGls & 1.836 \\
\hline & Número de Economias & 2.559 \\
\hline & Média de v1 & 16,6 \\
\hline & Média de v2 & 16,9 \\
\hline & Média de v3 & 16,7 \\
\hline & Média de v4 & 17,0 \\
\hline & Consumo Médio nos 6 Meses Anteriores & 16,3 \\
\hline & Média de Consumo Posterior (v2, v3 e v4) & 16,9 \\
\hline \multirow[t]{8}{*}{ C7 } & Número de RGls & 1.076 \\
\hline & Número de Economias & 1.310 \\
\hline & Média de v1 & 18,0 \\
\hline & Média de v2 & 16,8 \\
\hline & Média de v3 & 19,2 \\
\hline & Média de v4 & 17,4 \\
\hline & Consumo Médio nos 6 Meses Anteriores & 17,8 \\
\hline & Média de Consumo Posterior (v2, v3 e v4) & 17,8 \\
\hline \multirow[t]{8}{*}{ C8 } & Número de RGls & 81 \\
\hline & Número de Economias & 112 \\
\hline & Média de v1 & 35,2 \\
\hline & Média de v2 & 44,4 \\
\hline & Média de v3 & 39,9 \\
\hline & Média de v4 & 43,1 \\
\hline & Consumo Médio nos 6 Meses Anteriores & 43,4 \\
\hline & Média de Consumo Posterior (v2, v3 e v4) & 42,5 \\
\hline \multirow[t]{8}{*}{ C9 } & Número de RGls & 1.503 \\
\hline & Número de Economias & 2.179 \\
\hline & Média de v1 & 27,9 \\
\hline & Média de v2 & 25,9 \\
\hline & Média de v3 & 26,2 \\
\hline & Média de v4 & 24,2 \\
\hline & Consumo Médio nos 6 Meses Anteriores & 25,8 \\
\hline & Média de Consumo Posterior (v2, v3 e v4) & 25,4 \\
\hline
\end{tabular}




\begin{tabular}{lrr} 
& & (continuação) \\
\hline C10 & Número de RGls \\
& Número de Economias & 79 \\
& Média de v1 & 90 \\
& Média de v2 & 46,4 \\
& Média de v3 & 42,2 \\
& Média de v4 & 37,3 \\
& Consumo Médio nos 6 Meses Anteriores & 47,2 \\
& Média de Consumo Posterior (v2, v3 e v4) & 42,9 \\
& 42,2 \\
\hline & 11.087 \\
Total Número de RGls & 15.834 \\
Total Número de Economias & $\mathbf{2 1 , 8}$ \\
Total Média de v1 & $\mathbf{2 1 , 8}$ \\
Total Média de v2 & $\mathbf{2 1 , 4}$ \\
Total Média de v3 & $\mathbf{2 1 , 4}$ \\
Total Média de v4 & $\mathbf{2 1 , 2}$ \\
Total Consumo Médio nos 6 Meses Anteriores & $\mathbf{2 1 , 5}$ \\
Total Média de Consumo Posterior (v2, v3 e v4)
\end{tabular}


Tabela 3.2: Totalização de consumo: Áreas de VRP Auto. (até 3 econ./Lig.)

\begin{tabular}{|c|c|c|}
\hline ÁREA & Valores & Total \\
\hline \multirow[t]{8}{*}{ C1 } & Número de RGls & 882 \\
\hline & Número de Economias & 973 \\
\hline & Média de v1 & 30,0 \\
\hline & Média de v2 & 31,5 \\
\hline & Média de v3 & 28,7 \\
\hline & Média de v4 & 26,6 \\
\hline & Consumo Médio nos 6 Meses Anteriores & 29,2 \\
\hline & Média de Consumo Posterior (v2, v3 e v4) & 28,9 \\
\hline \multirow[t]{8}{*}{ C2 } & Número de RGls & 277 \\
\hline & Número de Economias & 309 \\
\hline & Média de v1 & 22,0 \\
\hline & Média de v2 & 22,5 \\
\hline & Média de v3 & 22,3 \\
\hline & Média de v4 & 21,2 \\
\hline & Consumo Médio nos 6 Meses Anteriores & 22,6 \\
\hline & Média de Consumo Posterior (v2, v3 e v4) & 22,0 \\
\hline \multirow[t]{8}{*}{ C3 } & Número de RGls & 595 \\
\hline & Número de Economias & 649 \\
\hline & Média de v1 & 21,9 \\
\hline & Média de v2 & 23,4 \\
\hline & Média de v3 & 21,6 \\
\hline & Média de v4 & 21,8 \\
\hline & Consumo Médio nos 6 Meses Anteriores & 22,9 \\
\hline & Média de Consumo Posterior (v2, v3 e v4) & 22,3 \\
\hline \multirow[t]{8}{*}{ C4 } & Número de RGls & 391 \\
\hline & Número de Economias & 436 \\
\hline & Média de v1 & 20,7 \\
\hline & Média de v2 & 23,0 \\
\hline & Média de v3 & 22,3 \\
\hline & Média de v4 & 21,6 \\
\hline & Consumo Médio nos 6 Meses Anteriores & 22,1 \\
\hline & Média de Consumo Posterior (v2, v3 e v4) & 22,3 \\
\hline \multirow[t]{8}{*}{ C5 } & Número de RGls & 4.061 \\
\hline & Número de Economias & 5.373 \\
\hline & Média de v1 & 17,0 \\
\hline & Média de v2 & 17,0 \\
\hline & Média de v3 & 16,7 \\
\hline & Média de v4 & 17,9 \\
\hline & Consumo Médio nos 6 Meses Anteriores & 16,2 \\
\hline & Média de Consumo Posterior (v2, v3 e v4) & 17,2 \\
\hline
\end{tabular}


(continuação)

\begin{tabular}{|c|c|c|}
\hline \multirow[t]{8}{*}{ C6 } & Número de RGls & 1.798 \\
\hline & Número de Economias & 2.396 \\
\hline & Média de v1 & 16,2 \\
\hline & Média de v2 & 16,5 \\
\hline & Média de v3 & 16,2 \\
\hline & Média de v4 & 16,6 \\
\hline & Consumo Médio nos 6 Meses Anteriores & 15,9 \\
\hline & Média de Consumo Posterior (v2, v3 e v4) & 16,4 \\
\hline \multirow[t]{8}{*}{ C7 } & Número de RGls & 1.065 \\
\hline & Número de Economias & 1.263 \\
\hline & Média de v1 & 17,8 \\
\hline & Média de v2 & 16,7 \\
\hline & Média de v3 & 19,0 \\
\hline & Média de v4 & 17,2 \\
\hline & Consumo Médio nos 6 Meses Anteriores & 17,6 \\
\hline & Média de Consumo Posterior (v2, v3 e v4) & 17,6 \\
\hline \multirow[t]{8}{*}{ C8 } & Número de RGls & 78 \\
\hline & Número de Economias & 78 \\
\hline & Média de v1 & 24,1 \\
\hline & Média de v2 & 29,2 \\
\hline & Média de v3 & 27,3 \\
\hline & Média de v4 & 28,7 \\
\hline & Consumo Médio nos 6 Meses Anteriores & 29,6 \\
\hline & Média de Consumo Posterior (v2, v3 e v4) & 28,4 \\
\hline \multirow[t]{8}{*}{ C9 } & Número de RGls & 1.407 \\
\hline & Número de Economias & 1.534 \\
\hline & Média de v1 & 24,3 \\
\hline & Média de v2 & 22,4 \\
\hline & Média de v3 & 22,8 \\
\hline & Média de v4 & 21,1 \\
\hline & Consumo Médio nos 6 Meses Anteriores & 22,2 \\
\hline & Média de Consumo Posterior (v2, v3 e v4) & 22,1 \\
\hline
\end{tabular}


(continuação)

\begin{tabular}{llr}
\hline C10 & Número de RGls & 78 \\
& Número de Economias & 78 \\
& Média de v1 & 39,8 \\
& Média de v2 & 35,9 \\
& Média de v3 & 31,9 \\
& Média de v4 & 36,9 \\
& Consumo Médio nos 6 Meses Anteriores & 36,3 \\
& Média de Consumo Posterior (v2, v3 e v4) & 34,9 \\
\multicolumn{1}{l}{ Total Número de RGls } & $\mathbf{1 0 . 6 3 2}$ \\
Total Número de Economias & $\mathbf{1 3 . 0 8 9}$ \\
Total Média de v1 & $\mathbf{1 9 , 8}$ \\
Total Média de v2 & $\mathbf{1 9 , 7}$ \\
Total Média de v3 & $\mathbf{1 9 , 5}$ \\
Total Média de v4 & $\mathbf{1 9 , 4}$ \\
Total Consumo Médio nos 6 Meses Anteriores & $\mathbf{1 9 , 2}$ \\
Total Média de Consumo Posterior (v2, v3 e v4) & $\mathbf{1 9 , 5}$
\end{tabular}


Tabela 3.3: Totalização de consumo: Áreas de VRP Auto. (1 econ./Lig.)

\begin{tabular}{|c|c|c|}
\hline ÁREA & Valores & Total \\
\hline \multirow[t]{8}{*}{ C1 } & Número de RGls & 811 \\
\hline & Número de Economias & 811 \\
\hline & Média de v1 & 29,8 \\
\hline & Média de v2 & 31,2 \\
\hline & Média de v3 & 28,5 \\
\hline & Média de v4 & 26,3 \\
\hline & Consumo Médio nos 6 Meses Anteriores & 28,9 \\
\hline & Média de Consumo Posterior (v2, v3 e v4) & 28,7 \\
\hline \multirow[t]{8}{*}{ C2 } & Número de RGls & 247 \\
\hline & Número de Economias & 247 \\
\hline & Média de v1 & 21,4 \\
\hline & Média de v2 & 21,9 \\
\hline & Média de v3 & 21,6 \\
\hline & Média de v4 & 20,7 \\
\hline & Consumo Médio nos 6 Meses Anteriores & 22,0 \\
\hline & Média de Consumo Posterior (v2, v3 e v4) & 21,4 \\
\hline \multirow[t]{8}{*}{ C3 } & Número de RGls & 547 \\
\hline & Número de Economias & 547 \\
\hline & Média de v1 & 21,7 \\
\hline & Média de v2 & 23,1 \\
\hline & Média de v3 & 21,4 \\
\hline & Média de v4 & 21,5 \\
\hline & Consumo Médio nos 6 Meses Anteriores & 22,7 \\
\hline & Média de Consumo Posterior (v2, v3 e v4) & 22,0 \\
\hline \multirow[t]{8}{*}{ C4 } & Número de RGls & 352 \\
\hline & Número de Economias & 352 \\
\hline & Média de v1 & 20,5 \\
\hline & Média de v2 & 22,8 \\
\hline & Média de v3 & 22,1 \\
\hline & Média de v4 & 21,4 \\
\hline & Consumo Médio nos 6 Meses Anteriores & 21,7 \\
\hline & Média de Consumo Posterior (v2, v3 e v4) & 22,1 \\
\hline \multirow[t]{8}{*}{ C5 } & Número de RGls & 2.964 \\
\hline & Número de Economias & 2.964 \\
\hline & Média de v1 & 14,9 \\
\hline & Média de v2 & 14,8 \\
\hline & Média de v3 & 14,5 \\
\hline & Média de v4 & 15,6 \\
\hline & Consumo Médio nos 6 Meses Anteriores & 14,1 \\
\hline & Média de Consumo Posterior (v2, v3 e v4) & 15,0 \\
\hline
\end{tabular}


(continuação)

\begin{tabular}{|c|c|c|}
\hline \multirow[t]{8}{*}{ C6 } & Número de RGls & 1.283 \\
\hline & Número de Economias & 1.283 \\
\hline & Média de v1 & 14,3 \\
\hline & Média de v2 & 14,7 \\
\hline & Média de v3 & 14,4 \\
\hline & Média de v4 & 14,6 \\
\hline & Consumo Médio nos 6 Meses Anteriores & 14,1 \\
\hline & Média de Consumo Posterior (v2, v3 e v4) & 14,6 \\
\hline \multirow[t]{8}{*}{ C7 } & Número de RGls & 890 \\
\hline & Número de Economias & 890 \\
\hline & Média de v1 & 16,9 \\
\hline & Média de v2 & 15,9 \\
\hline & Média de v3 & 18,1 \\
\hline & Média de v4 & 16,4 \\
\hline & Consumo Médio nos 6 Meses Anteriores & 16,8 \\
\hline & Média de Consumo Posterior (v2, v3 e v4) & 16,8 \\
\hline \multirow[t]{8}{*}{ C8 } & Número de RGls & 78 \\
\hline & Número de Economias & 78 \\
\hline & Média de v1 & 24,1 \\
\hline & Média de v2 & 29,2 \\
\hline & Média de v3 & 27,3 \\
\hline & Média de v4 & 28,7 \\
\hline & Consumo Médio nos 6 Meses Anteriores & 29,6 \\
\hline & Média de Consumo Posterior (v2, v3 e v4) & 28,4 \\
\hline \multirow[t]{8}{*}{ C9 } & Número de RGls & 1.304 \\
\hline & Número de Economias & 1.304 \\
\hline & Média de v1 & 23,8 \\
\hline & Média de v2 & 21,9 \\
\hline & Média de v3 & 22,4 \\
\hline & Média de v4 & 20,5 \\
\hline & Consumo Médio nos 6 Meses Anteriores & 21,8 \\
\hline & Média de Consumo Posterior (v2, v3 e v4) & 21,6 \\
\hline
\end{tabular}


(continuação)

\begin{tabular}{llr}
\hline C10 & Número de RGls & 78 \\
& Número de Economias & 78 \\
& Média de v1 & 39,8 \\
& Média de v2 & 35,9 \\
& Média de v3 & 31,9 \\
& Média de v4 & 36,9 \\
& Consumo Médio nos 6 Meses Anteriores & 36,3 \\
& Média de Consumo Posterior (v2, v3 e v4) & 34,9 \\
\hline \multicolumn{1}{l}{ Total Número de RGls } & $\mathbf{8 . 5 5 4}$ \\
Total Número de Economias & $\mathbf{8 . 5 5 4}$ \\
Total Média de v1 & $\mathbf{1 9 , 0}$ \\
Total Média de v2 & $\mathbf{1 8 , 9}$ \\
Total Média de v3 & $\mathbf{1 8 , 6}$ \\
Total Média de v4 & $\mathbf{1 8 , 4}$ \\
Total Consumo Médio nos 6 Meses Anteriores & $\mathbf{1 8 , 4}$ \\
Total Média de Consumo Posterior (v2, v3 e v4) & $\mathbf{1 8 , 6}$
\end{tabular}


Tabela 4: Totalização dos dados de consumo: Áreas testemunha de VRP FIXA

\begin{tabular}{|c|c|c|}
\hline ÁREA & Valores & Total \\
\hline \multirow[t]{8}{*}{ F1 (Testem.) } & Número de RGls & 423 \\
\hline & Número de Economias & 559 \\
\hline & Média de v1 & 15,1 \\
\hline & Média de v2 & 14,5 \\
\hline & Média de v3 & 16,3 \\
\hline & Média de v4 & 16,6 \\
\hline & Consumo Médio nos 6 Meses Anteriores & 15,9 \\
\hline & Média de Consumo Posterior (v2, v3 e v4) & 15,8 \\
\hline \multirow[t]{8}{*}{ F2 (Testem.) } & Número de RGls & 374 \\
\hline & Número de Economias & 487 \\
\hline & Média de v1 & 16,4 \\
\hline & Média de v2 & 16,9 \\
\hline & Média de v3 & 17,8 \\
\hline & Média de v4 & 18,7 \\
\hline & Consumo Médio nos 6 Meses Anteriores & 18,5 \\
\hline & Média de Consumo Posterior (v2, v3 e v4) & 17,8 \\
\hline \multirow[t]{8}{*}{ F3 (Testem.) } & Número de RGls & 493 \\
\hline & Número de Economias & 648 \\
\hline & Média de v1 & 17,5 \\
\hline & Média de v2 & 16,4 \\
\hline & Média de v3 & 18,1 \\
\hline & Média de v4 & 16,5 \\
\hline & Consumo Médio nos 6 Meses Anteriores & 17,2 \\
\hline & Média de Consumo Posterior (v2, v3 e v4) & 17,0 \\
\hline \multirow[t]{8}{*}{ F4 (Testem.) } & Número de RGls & 135 \\
\hline & Número de Economias & 167 \\
\hline & Média de v1 & 20,0 \\
\hline & Média de v2 & 18,5 \\
\hline & Média de v3 & 19,0 \\
\hline & Média de v4 & 17,7 \\
\hline & Consumo Médio nos 6 Meses Anteriores & 19,7 \\
\hline & Média de Consumo Posterior (v2, v3 e v4) & 18,4 \\
\hline \multirow[t]{8}{*}{ F5 (Testem.) } & Número de RGls & 158 \\
\hline & Número de Economias & 386 \\
\hline & Média de v1 & 44,8 \\
\hline & Média de v2 & 45,9 \\
\hline & Média de v3 & 42,7 \\
\hline & Média de v4 & 42,4 \\
\hline & Consumo Médio nos 6 Meses Anteriores & 47,1 \\
\hline & Média de Consumo Posterior (v2, v3 e v4) & 43,6 \\
\hline
\end{tabular}


(continuação)

\begin{tabular}{|c|c|c|}
\hline \multirow[t]{8}{*}{ F6 (Testem.) } & Número de RGls & 272 \\
\hline & Número de Economias & 331 \\
\hline & Média de v1 & 14,1 \\
\hline & Média de v2 & 14,0 \\
\hline & Média de v3 & 14,8 \\
\hline & Média de v4 & 14,0 \\
\hline & Consumo Médio nos 6 Meses Anteriores & 15,4 \\
\hline & Média de Consumo Posterior (v2, v3 e v4) & 14,3 \\
\hline \multirow{8}{*}{ F7 (Testem.) } & Número de RGls & 440 \\
\hline & Número de Economias & 502 \\
\hline & Média de v1 & 17,7 \\
\hline & Média de v2 & 17,1 \\
\hline & Média de v3 & 18,6 \\
\hline & Média de v4 & 19,5 \\
\hline & Consumo Médio nos 6 Meses Anteriores & 19,7 \\
\hline & Média de Consumo Posterior (v2, v3 e v4) & 18,4 \\
\hline \multirow{8}{*}{ F8 (Testem.) } & Número de RGls & 537 \\
\hline & Número de Economias & 636 \\
\hline & Média de v1 & 22,5 \\
\hline & Média de v2 & 22,5 \\
\hline & Média de v3 & 21,8 \\
\hline & Média de v4 & 21,7 \\
\hline & Consumo Médio nos 6 Meses Anteriores & 22,6 \\
\hline & Média de Consumo Posterior (v2, v3 e v4) & 22,0 \\
\hline \multirow[t]{8}{*}{ F9 (Testem.) } & Número de RGls & 186 \\
\hline & Número de Economias & 196 \\
\hline & Média de v1 & 22,6 \\
\hline & Média de v2 & 20,5 \\
\hline & Média de v3 & 23,3 \\
\hline & Média de v4 & 21,4 \\
\hline & Consumo Médio nos 6 Meses Anteriores & 22,2 \\
\hline & Média de Consumo Posterior (v2, v3 e v4) & 21,7 \\
\hline \multirow[t]{8}{*}{ F10 (Testem.) } & Número de RGls & 686 \\
\hline & Número de Economias & 1.201 \\
\hline & Média de v1 & 44,4 \\
\hline & Média de v2 & 45,9 \\
\hline & Média de v3 & 40,9 \\
\hline & Média de v4 & 39,6 \\
\hline & Consumo Médio nos 6 Meses Anteriores & 43,6 \\
\hline & Média de Consumo Posterior (v2, v3 e v4) & 42,1 \\
\hline
\end{tabular}


(continuação)

\begin{tabular}{|c|c|c|}
\hline \multirow[t]{8}{*}{ F11 (Testem.) } & Número de RGls & 61 \\
\hline & Número de Economias & 73 \\
\hline & Média de v1 & 13,1 \\
\hline & Média de v2 & 11,9 \\
\hline & Média de v3 & 14,6 \\
\hline & Média de v4 & 14,6 \\
\hline & Consumo Médio nos 6 Meses Anteriores & 14,5 \\
\hline & Média de Consumo Posterior (v2, v3 e v4) & 13,7 \\
\hline \multirow[t]{8}{*}{ F12 (Testem.) } & Número de RGls & 540 \\
\hline & Número de Economias & 814 \\
\hline & Média de v1 & 18,9 \\
\hline & Média de v2 & 19,2 \\
\hline & Média de v3 & 21,9 \\
\hline & Média de v4 & 21,8 \\
\hline & Consumo Médio nos 6 Meses Anteriores & 22,6 \\
\hline & Média de Consumo Posterior (v2, v3 e v4) & 21,0 \\
\hline \multirow[t]{8}{*}{ F13 (Testem.) } & Número de RGls & 36 \\
\hline & Número de Economias & 142 \\
\hline & Média de v1 & 50,9 \\
\hline & Média de v2 & 51,1 \\
\hline & Média de v3 & 55 \\
\hline & Média de v4 & 51,5 \\
\hline & Consumo Médio nos 6 Meses Anteriores & 54,2 \\
\hline & Média de Consumo Posterior (v2, v3 e v4) & 52,6 \\
\hline \multirow[t]{8}{*}{ F14 (Testem.) } & Número de RGls & 35 \\
\hline & Número de Economias & 109 \\
\hline & Média de v1 & 55 \\
\hline & Média de v2 & 52 \\
\hline & Média de v3 & 50 \\
\hline & Média de v4 & 47,4 \\
\hline & Consumo Médio nos 6 Meses Anteriores & 48,5 \\
\hline & Média de Consumo Posterior (v2, v3 e v4) & 50,2 \\
\hline \multirow{8}{*}{ F15 (Testem.) } & Número de RGls & 360 \\
\hline & Número de Economias & 392 \\
\hline & Média de v1 & 13,5 \\
\hline & Média de v2 & 13,7 \\
\hline & Média de v3 & 14,0 \\
\hline & Média de v4 & 14,7 \\
\hline & Consumo Médio nos 6 Meses Anteriores & 13,0 \\
\hline & Média de Consumo Posterior (v2, v3 e v4) & 14 \\
\hline
\end{tabular}


(continuação)

\begin{tabular}{llr}
\hline F16 (Testem.) & Número de RGls & 251 \\
& Número de Economias & 327 \\
& Média de v1 & 15,1 \\
& Média de v2 & 14,6 \\
& Média de v3 & 16,6 \\
& Média de v4 & 13,5 \\
& Consumo Médio nos 6 Meses Anteriores & 16,3 \\
& Média de Consumo Posterior (v2, v3 e v4) & 14,9 \\
& Número de RGls & 422 \\
\hline & Número de Economias & 509 \\
& Média de v1 & 12,8 \\
& Média de v2 & 13,4 \\
& Média de v3 & 14,2 \\
& Média de v4 & 14,4 \\
& Consumo Médio nos 6 Meses Anteriores & 14,3 \\
& Média de Consumo Posterior (v2, v3 e v4) & 14,0 \\
\hline Total Número de RGls & $\mathbf{5 . 4 0 9}$ \\
Total Número de & \\
Economias & & $\mathbf{7 . 4 7 9}$ \\
Total Média de v1 & $\mathbf{2 1 , 8}$ \\
Total Média de v2 & $\mathbf{2 1 , 8}$ \\
Total Média de v3 & $\mathbf{2 2 , 1}$ \\
Total Média de v4 & $\mathbf{2 1 , 7}$ \\
Total Consumo Médio nos 6 Meses Anteriores & $\mathbf{2 2 , 7}$ \\
Total Média de Consumo Posterior (v2, v3 e v4) & $\mathbf{2 1 , 9}$
\end{tabular}


Tabela 4.1: Totalização: Áreas testemunha de VRP FIXA (até 12 econ./Lig.)

\begin{tabular}{|c|c|c|}
\hline ÁREA & Valores & Total \\
\hline \multirow[t]{8}{*}{ F1 (Testem.) } & Número de RGls & 423 \\
\hline & Número de Economias & 559 \\
\hline & Média de v1 & 15,1 \\
\hline & Média de v2 & 14,5 \\
\hline & Média de v3 & 16,3 \\
\hline & Média de v4 & 16,6 \\
\hline & Consumo Médio nos 6 Meses Anteriores & 15,9 \\
\hline & Média de Consumo Posterior (v2, v3 e v4) & 15,8 \\
\hline \multirow[t]{8}{*}{ F2 (Testem.) } & Número de RGls & 374 \\
\hline & Número de Economias & 487 \\
\hline & Média de v1 & 16,4 \\
\hline & Média de v2 & 16,9 \\
\hline & Média de v3 & 17,8 \\
\hline & Média de v4 & 18,7 \\
\hline & Consumo Médio nos 6 Meses Anteriores & 18,5 \\
\hline & Média de Consumo Posterior (v2, v3 e v4) & 17,8 \\
\hline \multirow[t]{8}{*}{ F3 (Testem.) } & Número de RGls & 493 \\
\hline & Número de Economias & 648 \\
\hline & Média de v1 & 17,5 \\
\hline & Média de v2 & 16,4 \\
\hline & Média de v3 & 18,1 \\
\hline & Média de v4 & 16,5 \\
\hline & Consumo Médio nos 6 Meses Anteriores & 17,2 \\
\hline & Média de Consumo Posterior (v2, v3 e v4) & 17,0 \\
\hline \multirow[t]{8}{*}{ F4 (Testem.) } & Número de RGls & 135 \\
\hline & Número de Economias & 167 \\
\hline & Média de v1 & 20,0 \\
\hline & Média de v2 & 18,5 \\
\hline & Média de v3 & 19,0 \\
\hline & Média de v4 & 17,7 \\
\hline & Consumo Médio nos 6 Meses Anteriores & 19,7 \\
\hline & Média de Consumo Posterior (v2, v3 e v4) & 18,4 \\
\hline \multirow[t]{8}{*}{ F5 (Testem.) } & Número de RGls & 150 \\
\hline & Número de Economias & 167 \\
\hline & Média de v1 & 22,1 \\
\hline & Média de v2 & 22,3 \\
\hline & Média de v3 & 19,8 \\
\hline & Média de v4 & 19,5 \\
\hline & Consumo Médio nos 6 Meses Anteriores & 22,8 \\
\hline & Média de Consumo Posterior (v2, v3 e v4) & 20,5 \\
\hline
\end{tabular}


(continuação)

\begin{tabular}{|c|c|c|}
\hline \multirow[t]{8}{*}{ F6 (Testem.) } & Número de RGls & 272 \\
\hline & Número de Economias & 331 \\
\hline & Média de v1 & 14,1 \\
\hline & Média de v2 & 14,0 \\
\hline & Média de v3 & 14,8 \\
\hline & Média de v4 & 14,0 \\
\hline & Consumo Médio nos 6 Meses Anteriores & 15,4 \\
\hline & Média de Consumo Posterior (v2, v3 e v4) & 14,3 \\
\hline \multirow[t]{8}{*}{ F7 (Testem.) } & Número de RGls & 440 \\
\hline & Número de Economias & 502 \\
\hline & Média de v1 & 17,7 \\
\hline & Média de v2 & 17 , \\
\hline & Média de v3 & 18, \\
\hline & Média de v4 & 19 , \\
\hline & Consumo Médio nos 6 Meses Anteriores & 19,7 \\
\hline & Média de Consumo Posterior (v2, v3 e v4) & 18,4 \\
\hline \multirow[t]{8}{*}{ F8 (Testem.) } & Número de RGls & 536 \\
\hline & Número de Economias & 621 \\
\hline & Média de v1 & 22 , \\
\hline & Média de v2 & 22, \\
\hline & Média de v3 & 21 , \\
\hline & Média de v4 & 21,4 \\
\hline & Consumo Médio nos 6 Meses Anteriores & 22,2 \\
\hline & Média de Consumo Posterior (v2, v3 e v4) & 21,6 \\
\hline \multirow[t]{8}{*}{ F9 (Testem.) } & Número de RGls & 186 \\
\hline & Número de Economias & 196 \\
\hline & Média de v1 & 22 , \\
\hline & Média de v2 & 20 , \\
\hline & Média de v3 & 23,3 \\
\hline & Média de v4 & 21,4 \\
\hline & Consumo Médio nos 6 Meses Anteriores & 22,2 \\
\hline & Média de Consumo Posterior (v2, v3 e v4) & 21,7 \\
\hline \multirow[t]{8}{*}{ F10 (Testem.) } & Número de RGls & 671 \\
\hline & Número de Economias & 739 \\
\hline & Média de v1 & 33,8 \\
\hline & Média de v2 & 35,7 \\
\hline & Média de v3 & 31,5 \\
\hline & Média de v4 & 29,6 \\
\hline & Consumo Médio nos 6 Meses Anteriores & 33, \\
\hline & Média de Consumo Posterior (v2, v3 e v4) & 32 , \\
\hline
\end{tabular}


(continuação)

\begin{tabular}{|c|c|c|}
\hline \multirow[t]{8}{*}{ F11 (Testem.) } & Número de RGls & 61 \\
\hline & Número de Economias & 73 \\
\hline & Média de v1 & 13,1 \\
\hline & Média de v2 & 11,9 \\
\hline & Média de v3 & 14,6 \\
\hline & Média de v4 & 14,6 \\
\hline & Consumo Médio nos 6 Meses Anteriores & 14,5 \\
\hline & Média de Consumo Posterior (v2, v3 e v4) & 13,7 \\
\hline \multirow[t]{8}{*}{ F12 (Testem.) } & Número de RGls & 539 \\
\hline & Número de Economias & 792 \\
\hline & Média de v1 & 19,0 \\
\hline & Média de v2 & 19,2 \\
\hline & Média de v3 & 21,9 \\
\hline & Média de v4 & 21,8 \\
\hline & Consumo Médio nos 6 Meses Anteriores & 22,5 \\
\hline & Média de Consumo Posterior (v2, v3 e v4) & 21,0 \\
\hline \multirow[t]{8}{*}{ F13 (Testem.) } & Número de RGls & 36 \\
\hline & Número de Economias & 142 \\
\hline & Média de v1 & 50,9 \\
\hline & Média de v2 & 51,1 \\
\hline & Média de v3 & 55,3 \\
\hline & Média de v4 & 51,5 \\
\hline & Consumo Médio nos 6 Meses Anteriores & 54,2 \\
\hline & Média de Consumo Posterior (v2, v3 e v4) & 52,6 \\
\hline \multirow[t]{8}{*}{ F14 (Testem.) } & Número de RGls & 35 \\
\hline & Número de Economias & 109 \\
\hline & Média de v1 & 55,4 \\
\hline & Média de v2 & 52,7 \\
\hline & Média de v3 & 50,6 \\
\hline & Média de v4 & 47,4 \\
\hline & Consumo Médio nos 6 Meses Anteriores & 48,5 \\
\hline & Média de Consumo Posterior (v2, v3 e v4) & 50,2 \\
\hline \multirow[t]{8}{*}{ F15 (Testem.) } & Número de RGls & 360 \\
\hline & Número de Economias & 392 \\
\hline & Média de v1 & 13,5 \\
\hline & Média de v2 & 13,7 \\
\hline & Média de v3 & 14,0 \\
\hline & Média de v4 & 14,7 \\
\hline & Consumo Médio nos 6 Meses Anteriores & 13,0 \\
\hline & Média de Consumo Posterior (v2, v3 e v4) & 14,1 \\
\hline
\end{tabular}


(continuação)

\begin{tabular}{llr}
\hline F16 (Testem.) & Número de RGls & 251 \\
& Número de Economias & 327 \\
& Média de v1 & 15,1 \\
& Média de v2 & 14,6 \\
& Média de v3 & 16,6 \\
& Média de v4 & 13,5 \\
& Consumo Médio nos 6 Meses Anteriores & 16,3 \\
& Média de Consumo Posterior (v2, v3 e v4) & 14,9 \\
& Número de RGls & 422 \\
\hline & Número de Economias & 509 \\
& Média de v1 & 12,8 \\
& Média de v2 & 13,4 \\
& Média de v3 & 14,2 \\
& Média de v4 & 14,4 \\
& Consumo Médio nos 6 Meses Anteriores & 14,3 \\
& Média de Consumo Posterior (v2, v3 e v4) & 14,0 \\
\hline Total Número de RGls & $\mathbf{5 . 3 8 4}$ \\
Total Número de Economias & $\mathbf{6 . 7 6 1}$ \\
Total Média de v1 & $\mathbf{1 9 , 7}$ \\
Total Média de v2 & $\mathbf{1 9 , 8}$ \\
Total Média de v3 & $\mathbf{2 0 , 2}$ \\
Total Média de v4 & $\mathbf{1 9 , 7}$ \\
Total Consumo Médio nos 6 Meses Anteriores & $\mathbf{2 0 , 6}$ \\
Total Média de Consumo Posterior (v2, v3 e v4) & $\mathbf{1 9 , 9}$
\end{tabular}


Tabela 4.2: Totalização: Áreas testemunha de VRP FIXA (até 3 econ./Lig.)

\begin{tabular}{|c|c|c|}
\hline ÁREA & Valores & Total \\
\hline \multirow[t]{8}{*}{ F1 (Testem.) } & Número de RGls & 415 \\
\hline & Número de Economias & 525 \\
\hline & Média de v1 & 14,6 \\
\hline & Média de v2 & 14,1 \\
\hline & Média de v3 & 15,9 \\
\hline & Média de v4 & 16,2 \\
\hline & Consumo Médio nos 6 Meses Anteriores & 15,5 \\
\hline & Média de Consumo Posterior (v2, v3 e v4) & 15,4 \\
\hline \multirow[t]{8}{*}{ F2 (Testem.) } & Número de RGls & 367 \\
\hline & Número de Economias & 459 \\
\hline & Média de v1 & 16,0 \\
\hline & Média de v2 & 16,6 \\
\hline & Média de v3 & 17,4 \\
\hline & Média de v4 & 18,3 \\
\hline & Consumo Médio nos 6 Meses Anteriores & 18,1 \\
\hline & Média de Consumo Posterior (v2, v3 e v4) & 17,4 \\
\hline \multirow[t]{8}{*}{ F3 (Testem.) } & Número de RGls & 486 \\
\hline & Número de Economias & 617 \\
\hline & Média de v1 & 17,4 \\
\hline & Média de v2 & 16,3 \\
\hline & Média de v3 & 17,8 \\
\hline & Média de v4 & 16,3 \\
\hline & Consumo Médio nos 6 Meses Anteriores & 17,1 \\
\hline & Média de Consumo Posterior (v2, v3 e v4) & 16,8 \\
\hline \multirow[t]{8}{*}{ F4 (Testem.) } & Número de RGls & 133 \\
\hline & Número de Economias & 156 \\
\hline & Média de v1 & 19,1 \\
\hline & Média de v2 & 17,7 \\
\hline & Média de v3 & 18,0 \\
\hline & Média de v4 & 17,0 \\
\hline & Consumo Médio nos 6 Meses Anteriores & 18,9 \\
\hline & Média de Consumo Posterior (v2, v3 e v4) & 17,6 \\
\hline \multirow[t]{8}{*}{ F5 (Testem.) } & Número de RGls & 148 \\
\hline & Número de Economias & 156 \\
\hline & Média de v1 & 20,3 \\
\hline & Média de v2 & 20,5 \\
\hline & Média de v3 & 18,1 \\
\hline & Média de v4 & 17,8 \\
\hline & Consumo Médio nos 6 Meses Anteriores & 21,0 \\
\hline & Média de Consumo Posterior (v2, v3 e v4) & 18,8 \\
\hline
\end{tabular}


(continuação)

\begin{tabular}{|c|c|c|}
\hline \multirow[t]{8}{*}{ F6 (Testem.) } & Número de RGls & 271 \\
\hline & Número de Economias & 327 \\
\hline & Média de v1 & 14,1 \\
\hline & Média de v2 & 14,1 \\
\hline & Média de v3 & 14,8 \\
\hline & Média de v4 & 14,0 \\
\hline & Consumo Médio nos 6 Meses Anteriores & 15,4 \\
\hline & Média de Consumo Posterior (v2, v3 e v4) & 14,3 \\
\hline \multirow[t]{8}{*}{ F7 (Testem.) } & Número de RGls & 437 \\
\hline & Número de Economias & 488 \\
\hline & Média de v1 & 17,5 \\
\hline & Média de v2 & 17,0 \\
\hline & Média de v3 & 18,4 \\
\hline & Média de v4 & 19,3 \\
\hline & Consumo Médio nos 6 Meses Anteriores & 19,5 \\
\hline & Média de Consumo Posterior (v2, v3 e v4) & 18,2 \\
\hline \multirow[t]{8}{*}{ F8 (Testem.) } & Número de RGls & 526 \\
\hline & Número de Economias & 579 \\
\hline & Média de v1 & 21,6 \\
\hline & Média de v2 & 21,8 \\
\hline & Média de v3 & 21,0 \\
\hline & Média de v4 & 21,0 \\
\hline & Consumo Médio nos 6 Meses Anteriores & 21,8 \\
\hline & Média de Consumo Posterior (v2, v3 e v4) & 21,2 \\
\hline \multirow[t]{8}{*}{ F9 (Testem.) } & Número de RGls & 186 \\
\hline & Número de Economias & 196 \\
\hline & Média de v1 & 22 \\
\hline & Média de v2 & 20,5 \\
\hline & Média de v3 & 23 , \\
\hline & Média de v4 & 21, \\
\hline & Consumo Médio nos 6 Meses Anteriores & 22,2 \\
\hline & Média de Consumo Posterior (v2, v3 e v4) & 21,7 \\
\hline \multirow[t]{8}{*}{ F10 (Testem.) } & Número de RGls & 663 \\
\hline & Número de Economias & 678 \\
\hline & Média de v1 & 32,0 \\
\hline & Média de v2 & 33,7 \\
\hline & Média de v3 & 29 , \\
\hline & Média de v4 & 28,0 \\
\hline & Consumo Médio nos 6 Meses Anteriores & 31,4 \\
\hline & Média de Consumo Posterior (v2, v3 e v4) & 30,6 \\
\hline
\end{tabular}


(continuação)

\begin{tabular}{|c|c|c|}
\hline \multirow[t]{8}{*}{ F11 (Testem.) } & Número de RGls & 61 \\
\hline & Número de Economias & 73 \\
\hline & Média de v1 & 13,1 \\
\hline & Média de v2 & 11,9 \\
\hline & Média de v3 & 14,6 \\
\hline & Média de v4 & 14,6 \\
\hline & Consumo Médio nos 6 Meses Anteriores & 14,5 \\
\hline & Média de Consumo Posterior (v2, v3 e v4) & 13,7 \\
\hline \multirow[t]{8}{*}{ F12 (Testem.) } & Número de RGls & 515 \\
\hline & Número de Economias & 677 \\
\hline & Média de v1 & 16,9 \\
\hline & Média de v2 & 17,1 \\
\hline & Média de v3 & 19,4 \\
\hline & Média de v4 & 19,7 \\
\hline & Consumo Médio nos 6 Meses Anteriores & 20,2 \\
\hline & Média de Consumo Posterior (v2, v3 e v4) & 18,7 \\
\hline \multirow[t]{8}{*}{ F13 (Testem.) } & Número de RGls & 27 \\
\hline & Número de Economias & 34 \\
\hline & Média de v1 & 19,5 \\
\hline & Média de v2 & 23,0 \\
\hline & Média de v3 & 21,6 \\
\hline & Média de v4 & 19,8 \\
\hline & Consumo Médio nos 6 Meses Anteriores & 21,0 \\
\hline & Média de Consumo Posterior (v2, v3 e v4) & 21,5 \\
\hline \multirow[t]{8}{*}{ F14 (Testem.) } & Número de RGls & 29 \\
\hline & Número de Economias & 37 \\
\hline & Média de v1 & 23 , \\
\hline & Média de v2 & 23,3 \\
\hline & Média de v3 & 22,4 \\
\hline & Média de v4 & 20,5 \\
\hline & Consumo Médio nos 6 Meses Anteriores & 20,9 \\
\hline & Média de Consumo Posterior (v2, v3 e v4) & 22,1 \\
\hline \multirow[t]{8}{*}{ F15 (Testem.) } & Número de RGls & 359 \\
\hline & Número de Economias & 388 \\
\hline & Média de v1 & 13 \\
\hline & Média de v2 & 13,7 \\
\hline & Média de v3 & 13,9 \\
\hline & Média de v4 & 14,6 \\
\hline & Consumo Médio nos 6 Meses Anteriores & 13,0 \\
\hline & Média de Consumo Posterior (v2, v3 e v4) & 14 \\
\hline
\end{tabular}


(continuação)

\begin{tabular}{llr}
\hline F16 (Testem.) & Número de RGls & 251 \\
& Número de Economias & 327 \\
& Média de v1 & 15,1 \\
& Média de v2 & 14,6 \\
& Média de v3 & 16,6 \\
& Média de v4 & 13,5 \\
& Consumo Médio nos 6 Meses Anteriores & 16,3 \\
& Média de Consumo Posterior (v2, v3 e v4) & 14,9 \\
& Número de RGls & 420 \\
\hline F17 (Testem.) & Número de Economias & 501 \\
& Média de v1 & 12,8 \\
& Média de v2 & 13,4 \\
& Média de v3 & 14,2 \\
& Média de v4 & 14,4 \\
& Consumo Médio nos 6 Meses Anteriores & 14,2 \\
& Média de Consumo Posterior (v2, v3 e v4) & 14,0 \\
\hline Total Número de RGls & $\mathbf{5 . 2 9 4}$ \\
Total Número de Economias & $\mathbf{6 . 2 1 8}$ \\
Total Média de v1 & $\mathbf{1 8 , 7}$ \\
Total Média de v2 & & $\mathbf{1 8 , 7}$ \\
Total Média de v3 & $\mathbf{1 9 , 1}$ \\
Total Média de v4 & & $\mathbf{1 8 , 7}$ \\
Total Consumo Médio nos 6 Meses Anteriores & $\mathbf{1 9 , 5}$ \\
Total Média de Consumo Posterior (v2, v3 e v4) & $\mathbf{1 8 , 8}$
\end{tabular}


Tabela 4.3: Totalização: Áreas testemunha de VRP FIXA (1 econ./Lig.)

\begin{tabular}{|c|c|c|}
\hline ÁREA & Valores & Total \\
\hline \multirow[t]{8}{*}{ F1 (Testem.) } & Número de RGls & 316 \\
\hline & Número de Economias & 316 \\
\hline & Média de v1 & 13,2 \\
\hline & Média de v2 & 12,7 \\
\hline & Média de v3 & 14,6 \\
\hline & Média de v4 & 14,8 \\
\hline & Consumo Médio nos 6 Meses Anteriores & 14,1 \\
\hline & Média de Consumo Posterior (v2, v3 e v4) & 14,1 \\
\hline \multirow[t]{8}{*}{ F2 (Testem.) } & Número de RGls & 289 \\
\hline & Número de Economias & 289 \\
\hline & Média de v1 & 14,8 \\
\hline & Média de v2 & 15,4 \\
\hline & Média de v3 & 16,2 \\
\hline & Média de v4 & 16,8 \\
\hline & Consumo Médio nos 6 Meses Anteriores & 16,7 \\
\hline & Média de Consumo Posterior (v2, v3 e v4) & 16,1 \\
\hline \multirow[t]{8}{*}{ F3 (Testem.) } & Número de RGls & 372 \\
\hline & Número de Economias & 372 \\
\hline & Média de v1 & 16,3 \\
\hline & Média de v2 & 15,1 \\
\hline & Média de v3 & 16,7 \\
\hline & Média de v4 & 15,4 \\
\hline & Consumo Médio nos 6 Meses Anteriores & 16,0 \\
\hline & Média de Consumo Posterior (v2, v3 e v4) & 15,7 \\
\hline \multirow[t]{8}{*}{ F4 (Testem.) } & Número de RGls & 112 \\
\hline & Número de Economias & 112 \\
\hline & Média de v1 & 17,8 \\
\hline & Média de v2 & 16,6 \\
\hline & Média de v3 & 16,6 \\
\hline & Média de v4 & 15,5 \\
\hline & Consumo Médio nos 6 Meses Anteriores & 17,8 \\
\hline & Média de Consumo Posterior (v2, v3 e v4) & 16,2 \\
\hline \multirow[t]{8}{*}{ F5 (Testem.) } & Número de RGls & 140 \\
\hline & Número de Economias & 140 \\
\hline & Média de v1 & 20,4 \\
\hline & Média de v2 & 20,6 \\
\hline & Média de v3 & 18,2 \\
\hline & Média de v4 & 17,8 \\
\hline & Consumo Médio nos 6 Meses Anteriores & 21,1 \\
\hline & Média de Consumo Posterior (v2, v3 e v4) & 18,9 \\
\hline
\end{tabular}


(continuação)

\begin{tabular}{|c|c|c|}
\hline \multirow[t]{8}{*}{ F6 (Testem.) } & Número de RGls & 226 \\
\hline & Número de Economias & 226 \\
\hline & Média de v1 & 13,4 \\
\hline & Média de v2 & 13,1 \\
\hline & Média de v3 & 13,7 \\
\hline & Média de v4 & 13,2 \\
\hline & Consumo Médio nos 6 Meses Anteriores & 14,4 \\
\hline & Média de Consumo Posterior (v2, v3 e v4) & 13,3 \\
\hline \multirow[t]{8}{*}{ F7 (Testem.) } & Número de RGls & 389 \\
\hline & Número de Economias & 389 \\
\hline & Média de v1 & 17,1 \\
\hline & Média de v2 & 16,6 \\
\hline & Média de v3 & 17,9 \\
\hline & Média de v4 & 18,8 \\
\hline & Consumo Médio nos 6 Meses Anteriores & 19,0 \\
\hline & Média de Consumo Posterior (v2, v3 e v4) & 17,7 \\
\hline \multirow[t]{8}{*}{ F8 (Testem.) } & Número de RGls & 483 \\
\hline & Número de Economias & 483 \\
\hline & Média de v1 & 21,3 \\
\hline & Média de v2 & 21,6 \\
\hline & Média de v3 & 20,6 \\
\hline & Média de v4 & 20,8 \\
\hline & Consumo Médio nos 6 Meses Anteriores & 21,4 \\
\hline & Média de Consumo Posterior (v2, v3 e v4) & 21,0 \\
\hline \multirow[t]{8}{*}{ F9 (Testem.) } & Número de RGls & 179 \\
\hline & Número de Economias & 179 \\
\hline & Média de v1 & 22,6 \\
\hline & Média de v2 & 20,5 \\
\hline & Média de v3 & 23,3 \\
\hline & Média de v4 & 21,3 \\
\hline & Consumo Médio nos 6 Meses Anteriores & 22,2 \\
\hline & Média de Consumo Posterior (v2, v3 e v4) & 21,7 \\
\hline \multirow[t]{8}{*}{ F10 (Testem.) } & Número de RGls & 649 \\
\hline & Número de Economias & 649 \\
\hline & Média de v1 & 32,1 \\
\hline & Média de v2 & 33,9 \\
\hline & Média de v3 & 30,1 \\
\hline & Média de v4 & 28,2 \\
\hline & Consumo Médio nos 6 Meses Anteriores & 31,5 \\
\hline & Média de Consumo Posterior (v2, v3 e v4) & 30 \\
\hline
\end{tabular}


(continuação)

\begin{tabular}{|c|c|c|}
\hline \multirow[t]{8}{*}{ F11 (Testem.) } & Número de RGls & 49 \\
\hline & Número de Economias & 49 \\
\hline & Média de v1 & 12,5 \\
\hline & Média de v2 & 11,5 \\
\hline & Média de v3 & 13,8 \\
\hline & Média de v4 & 13,7 \\
\hline & Consumo Médio nos 6 Meses Anteriores & 14,0 \\
\hline & Média de Consumo Posterior (v2, v3 e v4) & 13,0 \\
\hline \multirow[t]{8}{*}{ F12 (Testem.) } & Número de RGls & 388 \\
\hline & Número de Economias & 388 \\
\hline & Média de v1 & 15,3 \\
\hline & Média de v2 & 15,6 \\
\hline & Média de v3 & 17,5 \\
\hline & Média de v4 & 18,1 \\
\hline & Consumo Médio nos 6 Meses Anteriores & 18,3 \\
\hline & Média de Consumo Posterior (v2, v3 e v4) & 17,1 \\
\hline \multirow[t]{8}{*}{ F13 (Testem.) } & Número de RGls & 20 \\
\hline & Número de Economias & 20 \\
\hline & Média de v1 & 20,7 \\
\hline & Média de v2 & 25 , \\
\hline & Média de v3 & 20,5 \\
\hline & Média de v4 & 17,9 \\
\hline & Consumo Médio nos 6 Meses Anteriores & 21,2 \\
\hline & Média de Consumo Posterior (v2, v3 e v4) & 21,1 \\
\hline \multirow[t]{8}{*}{ F14 (Testem.) } & Número de RGls & 22 \\
\hline & Número de Economias & 22 \\
\hline & Média de v1 & 24,9 \\
\hline & Média de v2 & 24,0 \\
\hline & Média de v3 & 21,9 \\
\hline & Média de v4 & 21,5 \\
\hline & Consumo Médio nos 6 Meses Anteriores & 21,9 \\
\hline & Média de Consumo Posterior (v2, v3 e v4) & 22,5 \\
\hline \multirow{8}{*}{ F15 (Testem.) } & Número de RGls & 333 \\
\hline & Número de Economias & 333 \\
\hline & Média de v1 & 13,2 \\
\hline & Média de v2 & 13,5 \\
\hline & Média de v3 & 13,6 \\
\hline & Média de v4 & 14,3 \\
\hline & Consumo Médio nos 6 Meses Anteriores & 12,8 \\
\hline & Média de Consumo Posterior (v2, v3 e v4) & 13 \\
\hline
\end{tabular}


(continuação)

\begin{tabular}{llr}
\hline F16 (Testem.) & Número de RGls & 186 \\
& Número de Economias & 186 \\
& Média de v1 & 14,7 \\
& Média de v2 & 13,8 \\
& Média de v3 & 15,8 \\
& Média de v4 & 12,9 \\
& Consumo Médio nos 6 Meses Anteriores & 15,9 \\
& Média de Consumo Posterior (v2, v3 e v4) & 14,2 \\
& Número de RGls & 344 \\
\hline & Número de Economias & 344 \\
& Média de v1 & 12,1 \\
& Média de v2 & 12,9 \\
& Média de v3 & 13,7 \\
& Média de v4 & 13,7 \\
& Consumo Médio nos 6 Meses Anteriores & 13,6 \\
& Média de Consumo Posterior (v2, v3 e v4) & 13,4 \\
\hline Total Número de RGls & $\mathbf{4 . 4 9 7}$ \\
Total Número de Economias & $\mathbf{4 . 4 9 7}$ \\
Total Média de v1 & & $\mathbf{1 8 , 5}$ \\
Total Média de v2 & & $\mathbf{1 8 , 6}$ \\
Total Média de v3 & & $\mathbf{1 8 , 7}$ \\
Total Média de v4 & $\mathbf{1 8 , 3}$ \\
Total Consumo Médio nos 6 Meses Anteriores & $\mathbf{1 9 , 2}$ \\
Total Média de Consumo Posterior (v2, v3 e v4) & $\mathbf{1 8 , 5}$
\end{tabular}


Tabela 5: Totalização de consumo: Áreas testemunha de VRP AUTOMÁTICA

\begin{tabular}{|c|c|c|}
\hline ÁREA & Valores & Total \\
\hline \multirow[t]{8}{*}{ C1 (Testem.) } & Número de RGls & 1.662 \\
\hline & Número de Economias & 3.458 \\
\hline & Média de v1 & 36,6 \\
\hline & Média de v2 & 38,2 \\
\hline & Média de v3 & 34,6 \\
\hline & Média de v4 & 37,6 \\
\hline & Consumo Médio nos 6 Meses Anteriores & 36,1 \\
\hline & Média de Consumo Posterior (v2, v3 e v4) & 36,8 \\
\hline \multirow[t]{8}{*}{ C2 1 (Testem.) } & Número de RGls & 47 \\
\hline & Número de Economias & 368 \\
\hline & Média de v1 & 82,2 \\
\hline & Média de v2 & 90,6 \\
\hline & Média de v3 & 85,0 \\
\hline & Média de v4 & 88,8 \\
\hline & Consumo Médio nos 6 Meses Anteriores & 88,0 \\
\hline & Média de Consumo Posterior (v2, v3 e v4) & 88,1 \\
\hline \multirow[t]{8}{*}{ C3 (Testem.) } & Número de RGls & 43 \\
\hline & Número de Economias & 130 \\
\hline & Média de v1 & 49,3 \\
\hline & Média de v2 & 50,5 \\
\hline & Média de v3 & 61,7 \\
\hline & Média de v4 & 61,6 \\
\hline & Consumo Médio nos 6 Meses Anteriores & 52,8 \\
\hline & Média de Consumo Posterior (v2, v3 e v4) & 57,9 \\
\hline \multirow[t]{8}{*}{ C4 (Testem.) } & Número de RGls & 182 \\
\hline & Número de Economias & 344 \\
\hline & Média de v1 & 27,8 \\
\hline & Média de v2 & 29,6 \\
\hline & Média de v3 & 27,7 \\
\hline & Média de v4 & 29,8 \\
\hline & Consumo Médio nos 6 Meses Anteriores & 30,0 \\
\hline & Média de Consumo Posterior (v2, v3 e v4) & 29,0 \\
\hline \multirow[t]{8}{*}{ C5 (Testem.) } & Número de RGls & 1.275 \\
\hline & Número de Economias & 1.730 \\
\hline & Média de v1 & 18,8 \\
\hline & Média de v2 & 17,3 \\
\hline & Média de v3 & 17,6 \\
\hline & Média de v4 & 17,9 \\
\hline & Consumo Médio nos 6 Meses Anteriores & 16,8 \\
\hline & Média de Consumo Posterior (v2, v3 e v4) & 17,6 \\
\hline
\end{tabular}


(continuação)

\begin{tabular}{llr}
\hline C6 (Testem.) & Número de RGls & 1.588 \\
& Número de Economias & 2.064 \\
& Média de v1 & 16,5 \\
& Média de v2 & 17,7 \\
& Média de v3 & 17,4 \\
& Média de v4 & 17,9 \\
& Consumo Médio nos 6 Meses Anteriores & 16,6 \\
& Média de Consumo Posterior (v2, v3 e v4) & 17,6 \\
& Número de RGls & 448 \\
C7 (Testem.) & Número de Economias & 600 \\
& Média de v1 & 19,8 \\
& Média de v2 & 18,5 \\
& Média de v3 & 19,7 \\
& Média de v4 & 19,8 \\
& Consumo Médio nos 6 Meses Anteriores & 19,3 \\
& Média de Consumo Posterior (v2, v3 e v4) & 19,3 \\
& Número de RGls & 171 \\
& Número de Economias & 958 \\
& Média de v1 & 75,1 \\
& Média de v2 & 90,1 \\
& Média de v3 & 75,8 \\
& Média de v4 & 80,0 \\
& Consumo Médio nos 6 Meses Anteriores & 83,5 \\
& Média de Consumo Posterior (v2, v3 e v4) & 82,0 \\
& Número de RGls & 904 \\
& Número de Economias & 1.902 \\
& Média de v1 & 41,5 \\
& Média de v2 & 37,9 \\
& Média de v3 & 40,3 \\
& Média de v4 & 37,7 \\
& Consumo Médio nos 6 Meses Anteriores & 38,9 \\
& Média de Consumo Posterior (v2, v3 e v4) & 38,6 \\
\hline C9 (Testem.) & & (continua) \\
& & \\
& &
\end{tabular}


(continuação)

\begin{tabular}{llr}
\hline C10 (Testem.) & Número de RGls & 112 \\
& Número de Economias & 378 \\
& Média de v1 & 61,8 \\
& Média de v2 & 63,9 \\
& Média de v3 & 61,6 \\
& Média de v4 & 64,7 \\
& Consumo Médio nos 6 Meses Anteriores & 58,8 \\
$\quad$ Média de Consumo Posterior (v2, v3 e v4) & 63,4 \\
\hline Total Número de RGls & $\mathbf{6 . 4 3 2}$ \\
Total Número de Economias & $\mathbf{1 1 . 9 3 2}$ \\
Total Média de v1 & $\mathbf{2 9 , 2}$ \\
Total Média de v2 & $\mathbf{2 9 , 6}$ \\
Total Média de v3 & $\mathbf{2 8 , 7}$ \\
Total Média de v4 & $\mathbf{2 9 , 5}$ \\
Total Consumo Médio nos 6 Meses Anteriores & $\mathbf{2 8 , 6}$ \\
Total Média de Consumo Posterior (v2, v3 e v4) & $\mathbf{2 9 , 3}$
\end{tabular}


Tabela 5.1: Totalização: Áreas testemunha de VRP AUTO (até 12 econ./Lig.)

\begin{tabular}{|c|c|c|}
\hline ÁREA & Valores & Total \\
\hline \multirow[t]{8}{*}{ C1 (Testem.) } & Número de RGls & 1.628 \\
\hline & Número de Economias & 2.596 \\
\hline & Média de v1 & 29,8 \\
\hline & Média de v2 & 31,0 \\
\hline & Média de v3 & 27,8 \\
\hline & Média de v4 & 30,7 \\
\hline & Consumo Médio nos 6 Meses Anteriores & 29,4 \\
\hline & Média de Consumo Posterior (v2, v3 e v4) & 29,8 \\
\hline \multirow[t]{8}{*}{ C2 (Testem.) } & Número de RGls & 46 \\
\hline & Número de Economias & 47 \\
\hline & Média de v1 & 42,5 \\
\hline & Média de v2 & 45,7 \\
\hline & Média de v3 & 43,0 \\
\hline & Média de v4 & 41,4 \\
\hline & Consumo Médio nos 6 Meses Anteriores & 45,7 \\
\hline & Média de Consumo Posterior (v2, v3 e v4) & 43,4 \\
\hline \multirow[t]{8}{*}{ C3 (Testem.) } & Número de RGls & 41 \\
\hline & Número de Economias & 58 \\
\hline & Média de v1 & 35,7 \\
\hline & Média de v2 & 37,0 \\
\hline & Média de v3 & 36,9 \\
\hline & Média de v4 & 38,7 \\
\hline & Consumo Médio nos 6 Meses Anteriores & 37,7 \\
\hline & Média de Consumo Posterior (v2, v3 e v4) & 37,5 \\
\hline \multirow[t]{8}{*}{ C4 (Testem.) } & Número de RGls & 179 \\
\hline & Número de Economias & 285 \\
\hline & Média de v1 & 23,2 \\
\hline & Média de v2 & 24,8 \\
\hline & Média de v3 & 22,3 \\
\hline & Média de v4 & 24,5 \\
\hline & Consumo Médio nos 6 Meses Anteriores & 25,5 \\
\hline & Média de Consumo Posterior (v2, v3 e v4) & 23,8 \\
\hline \multirow[t]{8}{*}{ C5 (Testem.) } & Número de RGls & 1.268 \\
\hline & Número de Economias & 1.618 \\
\hline & Média de v1 & 17,2 \\
\hline & Média de v2 & 15,7 \\
\hline & Média de v3 & 16,1 \\
\hline & Média de v4 & 16,3 \\
\hline & Consumo Médio nos 6 Meses Anteriores & 15,3 \\
\hline & Média de Consumo Posterior (v2, v3 e v4) & 16,0 \\
\hline
\end{tabular}


(continuação)

\begin{tabular}{llr}
\hline C6 (Testem.) & Número de RGls & 1.588 \\
& Número de Economias & 2.064 \\
& Média de v1 & 16,5 \\
& Média de v2 & 17,7 \\
& Média de v3 & 17,4 \\
& Média de v4 & 17,9 \\
& Consumo Médio nos 6 Meses Anteriores & 16,6 \\
& Média de Consumo Posterior (v2, v3 e v4) & 17,6 \\
C7 (Testem.) & Número de RGls & 446 \\
& Número de Economias & 542 \\
& Média de v1 & 18,3 \\
& Média de v2 & 17,0 \\
& Média de v3 & 18,3 \\
& Média de v4 & 18,3 \\
& Consumo Médio nos 6 Meses Anteriores & 17,6 \\
& Média de Consumo Posterior (v2, v3 e v4) & 17,9 \\
& Número de RGls & 157 \\
C8 (Testem.) & Número de Economias & 200 \\
& Média de v1 & 27,9 \\
& Média de v2 & 34,7 \\
& Média de v3 & 28,8 \\
& Média de v4 & 29,5 \\
& Consumo Médio nos 6 Meses Anteriores & 32,5 \\
& Média de Consumo Posterior (v2, v3 e v4) & 31,0 \\
& Número de RGls & 877 \\
& Número de Economias & 1.117 \\
& Média de v1 & 27,7 \\
& Média de v2 & 26,1 \\
& Média de v3 & 26,8 \\
& Média de v4 & 25,2 \\
& Consumo Médio nos 6 Meses Anteriores & 25,7 \\
& Média de Consumo Posterior (v2, v3 e v4) & 26,1 \\
\hline C9 (Testem.) & & (continua) \\
& & \\
& &
\end{tabular}


(continuação)

\begin{tabular}{llr}
\hline C10 (Testem.) & Número de RGls & 104 \\
& Número de Economias & 183 \\
& Média de v1 & 35,3 \\
& Média de v2 & 32,6 \\
& Média de v3 & 30,8 \\
& Média de v4 & 33,0 \\
& Consumo Médio nos 6 Meses Anteriores & 31,7 \\
& Média de Consumo Posterior (v2, v3 e v4) & 32,1 \\
\hline Total Número de RGls & $\mathbf{6 . 3 3 4}$ \\
Total Número de Economias & $\mathbf{8 . 7 1 0}$ \\
Total Média de v1 & $\mathbf{2 2 , 8}$ \\
Total Média de v2 & $\mathbf{2 3 , 0}$ \\
Total Média de v3 & $\mathbf{2 2 , 1}$ \\
Total Média de v4 & $\mathbf{2 2 , 9}$ \\
Total Consumo Médio nos 6 Meses Anteriores & $\mathbf{2 2 , 2}$ \\
Total Média de Consumo Posterior (v2, v3 e v4) & $\mathbf{2 2 , 7}$
\end{tabular}


Tabela 5.2: Totalização: Áreas testemunha de VRP AUTO (até 3 econ./Lig.)

\begin{tabular}{|c|c|c|}
\hline ÁREA & Valores & Total \\
\hline \multirow[t]{8}{*}{ C1 (Testem.) } & Número de RGls & 1.486 \\
\hline & Número de Economias & 1.628 \\
\hline & Média de v1 & 25,5 \\
\hline & Média de v2 & 27,2 \\
\hline & Média de v3 & 23,4 \\
\hline & Média de v4 & 26,5 \\
\hline & Consumo Médio nos 6 Meses Anteriores & 25,2 \\
\hline & Média de Consumo Posterior (v2, v3 e v4) & 25,7 \\
\hline \multirow[t]{8}{*}{ C2 (Testem.) } & Número de RGls & 46 \\
\hline & Número de Economias & 47 \\
\hline & Média de v1 & 42,5 \\
\hline & Média de v2 & 45,7 \\
\hline & Média de v3 & 43,0 \\
\hline & Média de v4 & 41,4 \\
\hline & Consumo Médio nos 6 Meses Anteriores & 45,7 \\
\hline & Média de Consumo Posterior (v2, v3 e v4) & 43,4 \\
\hline \multirow[t]{8}{*}{ C3 (Testem.) } & Número de RGls & 39 \\
\hline & Número de Economias & 43 \\
\hline & Média de v1 & 33,7 \\
\hline & Média de v2 & 35,5 \\
\hline & Média de v3 & 36,5 \\
\hline & Média de v4 & 38,3 \\
\hline & Consumo Médio nos 6 Meses Anteriores & 36,4 \\
\hline & Média de Consumo Posterior (v2, v3 e v4) & 36,8 \\
\hline \multirow[t]{8}{*}{ C4 (Testem.) } & Número de RGls & 165 \\
\hline & Número de Economias & 185 \\
\hline & Média de v1 & 20,6 \\
\hline & Média de v2 & 21,9 \\
\hline & Média de v3 & 19,2 \\
\hline & Média de v4 & 21,2 \\
\hline & Consumo Médio nos 6 Meses Anteriores & 22,8 \\
\hline & Média de Consumo Posterior (v2, v3 e v4) & 20,8 \\
\hline \multirow[t]{8}{*}{ C5 (Testem.) } & Número de RGls & 1.254 \\
\hline & Número de Economias & 1.554 \\
\hline & Média de v1 & 17,0 \\
\hline & Média de v2 & 15,5 \\
\hline & Média de v3 & 15,8 \\
\hline & Média de v4 & 16,0 \\
\hline & Consumo Médio nos 6 Meses Anteriores & 15,0 \\
\hline & Média de Consumo Posterior (v2, v3 e v4) & 15,8 \\
\hline
\end{tabular}


(continuação)

\begin{tabular}{llr}
\hline C6 (Testem.) & Número de RGls & 1.561 \\
& Número de Economias & 1.948 \\
& Média de v1 & 16,1 \\
& Média de v2 & 17,2 \\
& Média de v3 & 16,9 \\
& Média de v4 & 17,4 \\
& Consumo Médio nos 6 Meses Anteriores & 16,2 \\
& Média de Consumo Posterior (v2, v3 e v4) & 17,2 \\
C7 (Testem.) & Número de RGls & 441 \\
& Número de Economias & 519 \\
& Média de v1 & 17,9 \\
& Média de v2 & 16,6 \\
& Média de v3 & 17,9 \\
& Média de v4 & 18,0 \\
& Consumo Médio nos 6 Meses Anteriores & 17,3 \\
& Média de Consumo Posterior (v2, v3 e v4) & 17,5 \\
& Número de RGls & 152 \\
C8 (Testem.) & Número de Economias & 167 \\
& Média de v1 & 24,9 \\
& Média de v2 & 31,0 \\
& Média de v3 & 26,4 \\
& Média de v4 & 27,2 \\
& Consumo Médio nos 6 Meses Anteriores & 29,5 \\
& Média de Consumo Posterior (v2, v3 e v4) & 28,2 \\
& Número de RGls & 848 \\
& Número de Economias & 911 \\
& Média de v1 & 25,1 \\
& Média de v2 & 23,8 \\
& Média de v3 & 24,3 \\
& Média de v4 & 22,7 \\
& Consumo Médio nos 6 Meses Anteriores & 23,5 \\
& Média de Consumo Posterior (v2, v3 e v4) & 23,6 \\
\hline C9 (Testem.) & $($ continua) \\
& & \\
& &
\end{tabular}


(continuação)

\begin{tabular}{llr}
\hline C10 (Testem.) & Número de RGls & 94 \\
& Número de Economias & 110 \\
& Média de v1 & 25,3 \\
& Média de v2 & 24,5 \\
& Média de v3 & 22,3 \\
$\quad$ Média de v4 & 24,3 \\
$\quad$ Consumo Médio nos 6 Meses Anteriores & 23,1 \\
$\quad$ Média de Consumo Posterior (v2, v3 e v4) & 23,7 \\
& $\mathbf{6 . 0 8 6}$ \\
Total Número de RGls & $\mathbf{7 . 1 1 2}$ \\
Total Número de Economias & $\mathbf{2 0 , 8}$ \\
Total Média de v1 & $\mathbf{2 1 , 1}$ \\
Total Média de v2 & $\mathbf{2 0 , 1}$ \\
Total Média de v3 & $\mathbf{2 0 , 9}$ \\
Total Média de v4 & $\mathbf{2 0 , 2}$ \\
Total Consumo Médio nos 6 Meses Anteriores & $\mathbf{2 0 , 7}$ \\
Total Média de Consumo Posterior (v2, v3 e v4)
\end{tabular}


Tabela 5.3: Totalização: Áreas testemunha de VRP AUTO (1 econ./Lig.)

\begin{tabular}{|c|c|c|}
\hline ÁREA & Valores & Total \\
\hline \multirow[t]{8}{*}{ C1 (Testem.) } & Número de RGls & 1.361 \\
\hline & Número de Economias & 1.361 \\
\hline & Média de v1 & 25,6 \\
\hline & Média de v2 & 27,4 \\
\hline & Média de v3 & 23,5 \\
\hline & Média de v4 & 26,6 \\
\hline & Consumo Médio nos 6 Meses Anteriores & 25,2 \\
\hline & Média de Consumo Posterior (v2, v3 e v4) & 25,8 \\
\hline \multirow[t]{8}{*}{ C2 (Testem.) } & Número de RGls & 45 \\
\hline & Número de Economias & 45 \\
\hline & Média de v1 & 43,0 \\
\hline & Média de v2 & 46,2 \\
\hline & Média de v3 & 43,6 \\
\hline & Média de v4 & 41,8 \\
\hline & Consumo Médio nos 6 Meses Anteriores & 46,3 \\
\hline & Média de Consumo Posterior (v2, v3 e v4) & 43,9 \\
\hline \multirow[t]{8}{*}{ C3 (Testem.) } & Número de RGls & 36 \\
\hline & Número de Economias & 36 \\
\hline & Média de v1 & 34,6 \\
\hline & Média de v2 & 36,9 \\
\hline & Média de v3 & 37,8 \\
\hline & Média de v4 & 39,9 \\
\hline & Consumo Médio nos 6 Meses Anteriores & 37,6 \\
\hline & Média de Consumo Posterior (v2, v3 e v4) & 38,2 \\
\hline \multirow[t]{8}{*}{ C4 (Testem.) } & Número de RGls & 148 \\
\hline & Número de Economias & 148 \\
\hline & Média de v1 & 21,0 \\
\hline & Média de v2 & 22,2 \\
\hline & Média de v3 & 18,6 \\
\hline & Média de v4 & 20,9 \\
\hline & Consumo Médio nos 6 Meses Anteriores & 22,7 \\
\hline & Média de Consumo Posterior (v2, v3 e v4) & 20,5 \\
\hline \multirow[t]{8}{*}{ C5 (Testem.) } & Número de RGls & 991 \\
\hline & Número de Economias & 991 \\
\hline & Média de v1 & 15,8 \\
\hline & Média de v2 & 14,3 \\
\hline & Média de v3 & 14,6 \\
\hline & Média de v4 & 14,9 \\
\hline & Consumo Médio nos 6 Meses Anteriores & 13,9 \\
\hline & Média de Consumo Posterior (v2, v3 e v4) & 14,6 \\
\hline
\end{tabular}


(continuação)

\begin{tabular}{llr}
\hline C6 (Testem.) & Número de RGls & 1.233 \\
& Número de Economias & 1.233 \\
& Média de v1 & 14,9 \\
& Média de v2 & 16,0 \\
& Média de v3 & 15,6 \\
& Média de v4 & 16,0 \\
& Consumo Médio nos 6 Meses Anteriores & 15,1 \\
& Média de Consumo Posterior (v2, v3 e v4) & 15,9 \\
& Número de RGls & 373 \\
C7 (Testem.) & Número de Economias & 373 \\
& Média de v1 & 16,6 \\
& Média de v2 & 15,6 \\
& Média de v3 & 16,8 \\
& Média de v4 & 16,7 \\
& Consumo Médio nos 6 Meses Anteriores & 16,2 \\
& Média de Consumo Posterior (v2, v3 e v4) & 16,3 \\
& Número de RGls & 139 \\
& Número de Economias & 139 \\
& Média de v1 & 24,6 \\
C8 (Testem.) & 30,9 \\
& Média de v2 & 26,0 \\
& Média de v3 & 26,7 \\
& Média de v4 & 29,2 \\
& Consumo Médio nos 6 Meses Anteriores & 27,9 \\
& Média de Consumo Posterior (v2, v3 e v4) & 795 \\
& Número de RGls & 795 \\
& Número de Economias & 25,1 \\
& Média de v1 & 23,8 \\
& Média de v2 & 24,2 \\
& Média de v3 & 22,6 \\
& Média de v4 & 23,4 \\
& Consumo Médio nos 6 Meses Anteriores & 23,5 \\
\hline Média de Consumo Posterior (v2, v3 e v4) & $($ continua)
\end{tabular}


(continuação)

\begin{tabular}{llr}
\hline C10 (Testem.) & Número de RGls & 80 \\
& Número de Economias & 80 \\
& Média de v1 & 24,9 \\
& Média de v2 & 24,5 \\
& Média de v3 & 21,7 \\
& Média de v4 & 23,7 \\
& Consumo Médio nos 6 Meses Anteriores & 23,0 \\
$\quad \quad$ Média de Consumo Posterior (v2, v3 e v4) & 23,3 \\
\hline Total Número de RGls & $\mathbf{5 . 2 0 1}$ \\
Total Número de Economias & $\mathbf{5 . 2 0 1}$ \\
Total Média de v1 & 20,5 \\
Total Média de v2 & 20,9 \\
Total Média de v3 & $\mathbf{1 9 , 7}$ \\
Total Média de v4 & $\mathbf{2 0 , 6}$ \\
Total Consumo Médio nos 6 Meses Anteriores & $\mathbf{2 0 , 0}$ \\
Total Média de Consumo Posterior (v2, v3 e v4) & $\mathbf{2 0 , 4}$
\end{tabular}




\section{APÊNDICE B: ANÁLISES DE CONSISTÊNCIA DAS SÉRIES DE DADOS DE DIFERENÇAS DE MÉDIA DE CONSUMOS}

As análises das séries de dados de consumo onde foram identificados outiliers, foram repetidas, após a exclusão desses dados considerados fora do padrão, até que não fosse identificado nenhum, sendo apresentada uma tabela para cada ciclo de análise.

Obs.: todos os valores de média de consumo e de diferenças de média de consumo são dados em $\mathrm{m}^{3} /$ mês/ligação. 
ANÁLISE 1: ÁREAS DE VRP E ÁREAS TESTEMUNHA (2)

BOX-PLOT COM CERCAS, DOS VALORES DE CONSUMO MÉDIO NAS ÁREAS DE VRP, PARA IDENTIFICAÇÃO DE OUTLIERS

\begin{tabular}{|c|c|c|c|c|c|c|c|c|c|}
\hline & VRP & ANTES (Xi) & APÓS (Yi) & $D i=(X i-Y i)$ & & MÉDIA: & 0,5 & & \\
\hline 1 & F15 & 20,1 & 22,3 & $-2,3$ & & AMPLITUDE: & 5,7 & 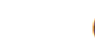 & \\
\hline 2 & F14 Test. & 48,5 & 50,2 & $-1,8$ & & $\mathrm{~N}^{0}$ CLASSES: & 7,1 & . & \\
\hline 3 & F15 Test. & 13,0 & 14,1 & $-1,2$ & & FAIXA: & 0,81 & 0 & \\
\hline 4 & C6 Test. & 16,6 & 17,6 & $-1,0$ & & & & & \\
\hline 5 & $\mathrm{C} 5$ & 16,8 & 17,8 & $-1,0$ & & & & & \\
\hline 6 & C5 Test. & 16,8 & 17,6 & $-0,8$ & Classe & Consumo & ni & fi & fac \\
\hline 7 & C1 Test. & 36,1 & 36,8 & $-0,7$ & 1 & $-2,5 a-1,6$ & 2 & 0,04 & 0,04 \\
\hline 8 & F13 & 22,9 & 23,4 & $-0,5$ & 2 & $-1,6$ a $-0,7$ & 4 & 0,08 & 0,12 \\
\hline 9 & C6 & 16,3 & 16,9 & $-0,5$ & 3 & $-0,7$ a 0,2 & 10 & 0,20 & 0,32 \\
\hline 10 & F14 & 20,3 & 20,8 & $-0,5$ & 4 & 0,2 a 1,1 & 18 & 0,36 & 0,68 \\
\hline 11 & F8 & 26,1 & 26,3 & $-0,2$ & 5 & 1,1 a 2,0 & 14 & 0,28 & 0,96 \\
\hline 12 & C2 Test. & 88,0 & 88,1 & $-0,2$ & 6 & 2,0 a 2,9 & 1 & 0,02 & 0,98 \\
\hline 13 & F12 & 18,8 & 18,9 & $-0,1$ & 7 & 2,9 a 3,8 & 1 & 0,02 & 1,00 \\
\hline 14 & F1 & 15,8 & 16,0 & $-0,1$ & & soma $=$ & 50 & & \\
\hline
\end{tabular}

\begin{tabular}{|c|c|c|c|c|}
15 & C7 Test. & 19,3 & 19,3 & $-0,1$ \\
\cline { 2 - 5 } 16 & F1 Test. & 15,9 & 15,8 & 0,1 \\
nyyyn
\end{tabular}

\begin{tabular}{|c|c|c|c|c|}
\hline 17 & C7 & 18,8 & 18,7 & 0,2 \\
\hline 1 & F3 Test. & 17,2 & 17,0 & 0,2 \\
\hline & F17 Test. & 14,3 & 14,0 & 0,2 \\
\hline
\end{tabular}

onde: $\mathrm{ni}=\mathrm{n}^{0}$ de ocorrências em cada classe de consumo $\mathrm{fi}=$ freqüência relativa do $n^{\circ}$ de ocorrência/classe fac $=$ freqüência acumulada do $n^{\circ}$ de ocorrências

\begin{tabular}{|c|c|c|c|c|}
\hline 20 & F3 & 17,3 & 17,0 & 0,2 \\
\hline 21 & C4 & 26,7 & 26,4 & 0,3 \\
\hline
\end{tabular}

Posição

\begin{tabular}{|c|c|c|c|c|c|c|c|c|}
\hline 21 & $\mathrm{C} 4$ & 26,7 & 26,4 & 0,3 & & $1 \mathrm{Q}=$ & 13,0 & $-0,1$ \\
\hline 22 & C9 Test. & 38,9 & 38,6 & 0,3 & Mediana: & $2 Q=$ & 25,5 & 0,5 \\
\hline 23 & F9 Test. & 22,2 & 21,7 & 0,5 & & $3 \mathrm{Q}=$ & 38,0 & 1,3 \\
\hline 24 & F10 & 43,9 & 43,4 & 0,5 & & $4 Q=$ & 50,5 & 3,5 \\
\hline 25 & F17 & 147 & 142 & 0.5 & & $\| Q=$ & 14 & \\
\hline
\end{tabular}

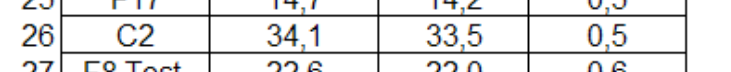

\begin{tabular}{|c|c|c|c|c|}
\cline { 2 - 4 } 27 & F8 Test. & 22,6 & 22,0 & 0,6 \\
\cline { 2 - 4 } 28 & C3 & 33,4 & 32,8 & 0,6 \\
\hline
\end{tabular}

\begin{tabular}{|c|c|c|c|c|}
\hline 28 & c3 & 334 & 328 & 0,6 \\
\hline 29 & $\mathrm{C9}$ & 436 & 429 & 0.7 \\
\hline . & F2 Test. & 18,5 & 17.8 & 0.7 \\
\hline
\end{tabular}

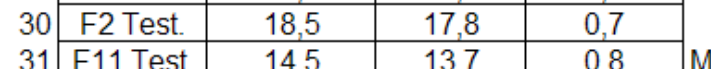

\begin{tabular}{c|c|c|c|c|}
31 & F11 Test. & 14,5 & 13,7 & 0,8 \\
\cline { 2 - 5 } 32 & F6 & 14,4 & 13,6 & 0,8 \\
\cline { 2 - 5 } & &
\end{tabular}

\begin{tabular}{|c|c|c|c|c|}
33 & C4 Test. & 30,0 & 29,0 & 1,0 \\
\cline { 2 - 5 } 34 & C1 & 707 & 697 & 10 \\
\hline
\end{tabular}

\begin{tabular}{c|c|c|c|c|}
34 & C1 & 70,7 & 69,7 & 1,0 \\
\cline { 2 - 5 } 36 & F6 Test. & 15,4 & 14,3 & 1,1 \\
\cline { 2 - 5 } 36 & F11 & 16,8 & 15,6 & 1,2 \\
\hline
\end{tabular}

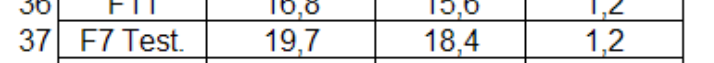

\begin{tabular}{|c|c|c|c|c|}
\hline 38 & F4 Test. & 19,7 & 18,4 & 1,3 \\
\hline 30 [ & $\mathrm{F} 2$ & 20,3 & 19,0 & 1,3 \\
\hline
\end{tabular}

\begin{tabular}{|c|c|c|c|c|}
39 & $F 2$ & 20,3 & 19,0 & 1,3 \\
\cline { 2 - 5 } 40 & $F 7$ & 18,9 & 17,5 & 1,4 \\
\cline { 2 - 4 } & &
\end{tabular}

\begin{tabular}{|l|l|l|l|l|}
41 & F16 Test. & 16,3 & 14,9 & 1,5 \\
\cline { 2 - 5 } 42 & F10 Test. & 43,6 & 42,1 & 1,5 \\
\hline
\end{tabular}

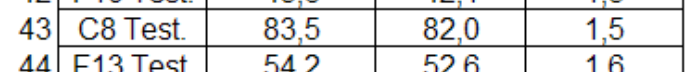

\begin{tabular}{|c|c|c|c|c|}
\hline & & & & \\
\hline 44 & F13 Test. & 54,2 & 52,6 & 1,6 \\
\hline 45 & F16 & 16,3 & 14,7 & 1,6 \\
\hline
\end{tabular}

\begin{tabular}{|c|c|c|c|c|}
46 & F12 Test. & 22,6 & 21,0 & 1,6 \\
\cline { 2 - 5 } 47 & F4 & 18,9 & 17,1 & 1,7 \\
\hline
\end{tabular}

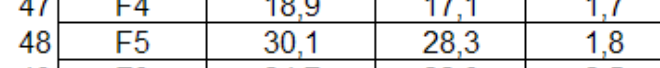

Dessa análise constata-se que os consumos médios das áreas de VRP F15 e Testemunha F5 foram classificadas

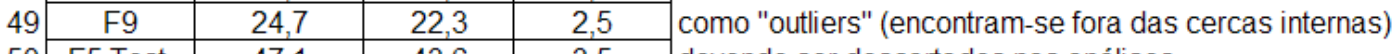

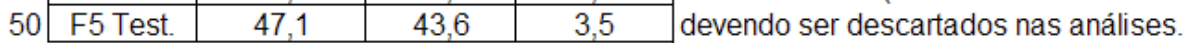

${ }^{(*)}$ Xi e Yi = valores de consumo médio em $\mathrm{m}^{3} / \mathrm{mês} /$ ligação

${ }^{* *}$ F1 a F15 = áreas com VRP Fixa; C1 a C10 = áreas com VRP com controle Automático.

${ }^{(* * *)}$ Test = áreas testemunha de áreas de VRP (áreas que não estão sob efeito da VRP. 
ANÁLISE 1: ÁREAS DE VRP E ÁREAS TESTEMUNHA (3)

BOX-PLOT COM CERCAS, DOS VALORES DE CONSUMO MÉDIO NAS ÁREAS DE VRP, PARA IDENTIFICAÇÃO DE OUTLIERS

\begin{tabular}{|c|c|c|c|c|c|c|c|c|c|}
\hline & VRP & ANTES $(\mathrm{Xi})$ & APÓS (Yi) & $(X i-Y i)$ & & MÉDIA: & 0,5 & & \\
\hline 1 & F14 Test. & 48,5 & 50,2 & $-1,8$ & & AMPLITUDE: & 4,3 & & \\
\hline 2 & F15 Test. & 13,0 & 14,1 & $-1,2$ & & $\mathrm{~N}^{\circ}$ CLASSES: & 6,9 & & \\
\hline 3 & C6 Test. & 16,6 & 17,6 & $-1,0$ & & FAIXA: & 0,62 & & \\
\hline 4 & $\mathrm{C} 5$ & 16,8 & 17,8 & $-1,0$ & & & & & \\
\hline 5 & C5 Test. & 16,8 & 17,6 & $-0,8$ & & & & & \\
\hline 6 & C1 Test. & 36,1 & 36,8 & $-0,7$ & Classe & Consumo & ni & fi & fac \\
\hline 7 & F13 & 22,9 & 23,4 & $-0,5$ & 1 & $-2,0 a-1,3$ & 2 & 0,04 & 0,04 \\
\hline 8 & C6 & 16,3 & 16,9 & $-0,5$ & 2 & $-1,3$ a $-0,6$ & 4 & 0,08 & 0,13 \\
\hline 9 & F14 & 20,3 & 20,8 & $-0,5$ & 3 & $-0,6$ a 0,1 & 8 & 0,17 & 0,29 \\
\hline 10 & F8 & 26,1 & 26,3 & $-0,2$ & 4 & 0,1 a 0,8 & 15 & 0,31 & 0,60 \\
\hline 11 & C2 Test. & 88,0 & 88,1 & $-0,2$ & 5 & 0,8 a 1,5 & 10 & 0,21 & 0,81 \\
\hline 12 & F12 & 18,8 & 18,9 & $-0,1$ & 6 & 1,5 a 2,2 & 8 & 0,17 & 0,98 \\
\hline 13 & F1 & 15,8 & 16,0 & $-0,1$ & 7 & 2,2 a 2,9 & 1 & 0,02 & 1,00 \\
\hline 14 & C7 Test. & 19,3 & 19,3 & $-0,1$ & & soma $=$ & 48 & & \\
\hline
\end{tabular}

onde: $\mathrm{ni}=\mathrm{n}^{0}$ de ocorrências em cada classe de consumo $\mathrm{fi}=$ freqüência relativa do $\mathrm{n}^{0}$ de ocorrência/classe fac $=$ freqüência acumulada do $n^{0}$ de ocorrências

\begin{tabular}{|c|c|c|c|}
\hline F3 Test. & 17,2 & 17,0 & 0,2 \\
\hline $\begin{array}{l}\text { F17 Test. } \\
\text { F17 Test }\end{array}$ & 14,3 & 14,0 & 0,2 \\
\hline
\end{tabular}

\begin{tabular}{c|c|c|c|}
\hline F3 & 17,3 & 17,0 & 0,2 \\
\hline
\end{tabular}

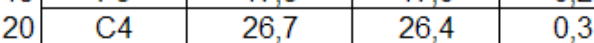

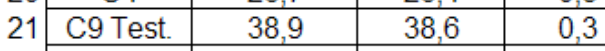

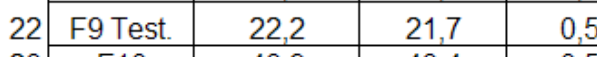

\begin{tabular}{l|l|l|l|l}
\cline { 2 - 5 } 23 & $\mathrm{~F} 10$ & 43,9 & 43,4 & 0,5 \\
\cline { 2 - 5 } 24 & $\mathrm{~F} 17$ & 14,7 & 14,2 & 0,5 \\
\hline
\end{tabular}

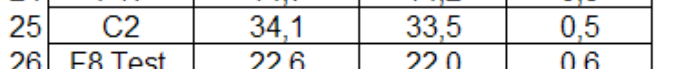

\begin{tabular}{l|c|c|c|c|}
27 & $\mathrm{C} 3$ & 33,4 & 32,8 & 0,6 \\
\cline { 2 - 5 } 28 & 436 & 429 & 07
\end{tabular}

\begin{tabular}{|c|c|c|c|c|}
28 & C9 & 43,6 & 42,9 & 0,7 \\
\cline { 2 - 5 } 29 & F2 Test. & 18,5 & 17,8 & 0,7 \\
\hline
\end{tabular}

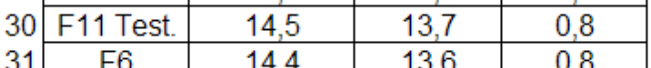

\begin{tabular}{r|c|c|c|c|}
32 & C4 Test. & 30,0 & 29,0 & 1,0 \\
\cline { 2 - 4 } & C Mediana: &
\end{tabular}

33 C1 10,70

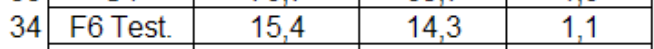

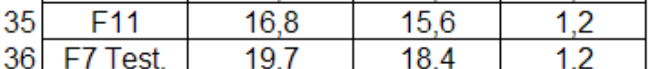

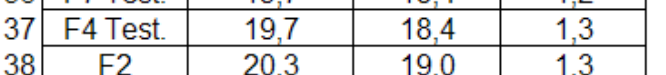

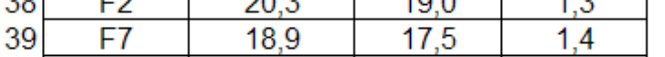

\begin{tabular}{l|l|l|l|l|}
40 & F16 Test. & 16,3 & 14,9 & 1,5 \\
\cline { 2 - 5 } & F10 Test & 43,6 & 421 & 15 \\
\hline
\end{tabular}

\begin{tabular}{l|l|l|l|r|}
42 & C8 Test. & 83,5 & 82,0 & 1,5 \\
\cline { 2 - 4 } & F 13 Test & 542 & 52,0 & 1,6 \\
\hline
\end{tabular}

\begin{tabular}{l|l|l|l|l}
43 & F13 Test. & 54,2 & 52,6 & 1,6
\end{tabular}

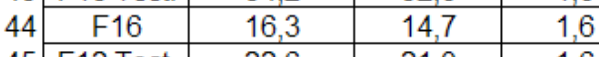

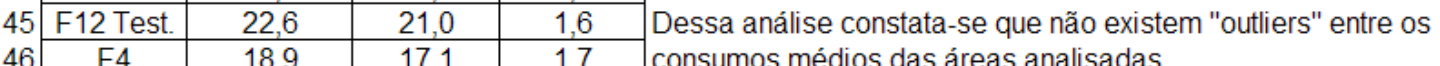

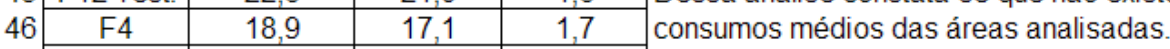

Posição

\begin{tabular}{rrr}
$1 \mathrm{Q}=$ & 12,5 & $-0,1$ \\
\hline $\mathrm{Q}=$ & 24,5 & 0,5 \\
\hline $3 \mathrm{Q}=$ & 36,5 & 1,2 \\
$4 \mathrm{Q}=$ & 48,5 & 2,5 \\
$\mathrm{IQ}=$ & 1,3 & \\
$\mathrm{~L} 1=$ & $1 \mathrm{Q}-1,5 \| \mathrm{Q}:$ & $-2,1$ \\
$\mathrm{~L}=$ & $1 \mathrm{Q}-3,0 \mathrm{Q}:$ & $-4,0$ \\
$\mathrm{U} 1=$ & $3 \mathrm{Q}+1,5 \| \mathrm{Q}$ & 3,2 \\
$\mathrm{U}=$ & $3 \mathrm{Q}+3,0 \| \mathrm{Q}$ & 5,1
\end{tabular}

\begin{tabular}{l|l|l|l|r|}
47 & F5 & 30,1 & 28,3 & 1,8 \\
\cline { 2 - 5 } 48 & F9 & 24,7 & 22,3 & 2,5 \\
\hline
\end{tabular}

${ }^{(*)} \mathrm{Xi}$ e $\mathrm{Yi}$ = valores de consumo médio em $\mathrm{m}^{3} / \mathrm{mês} /$ ligação

(*z) F1 a F15 = áreas com VRP Fixa; C1 a C10 = áreas com VRP com controle Automático.

(*kx) Test = áreas testemunha de áreas de VRP (áreas que não estão sob efeito da VRP. 
ANÁLISE 2: ÁREAS DE VRP (1)

BOX-PLOT COM CERCAS, DOS VALORES DE CONSUMO MÉDIO NAS ÁREAS DE VRP, PARA IDENTIFICAÇÃO DE OUTLIERS

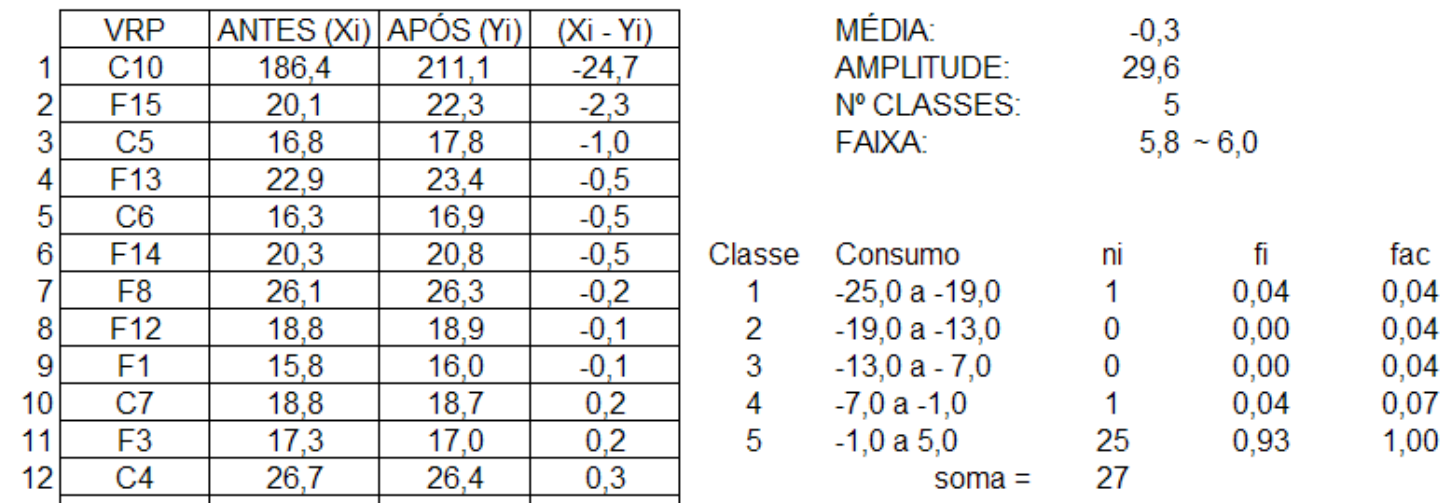

onde: $\mathrm{ni}=\mathrm{n}^{0}$ de ocorrências em cada classe de consumo $\mathrm{fi}=$ freqüência relativa do $\mathrm{n}^{0}$ de ocorrência/classe fac $=$ freqüência acumulada do $n^{0}$ de ocorrências

\begin{tabular}{|l|l|l|l}
\hline 15 & 14,7 & 14,2 & 0,5 \\
\hline
\end{tabular}

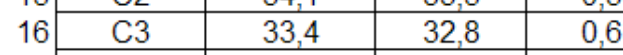

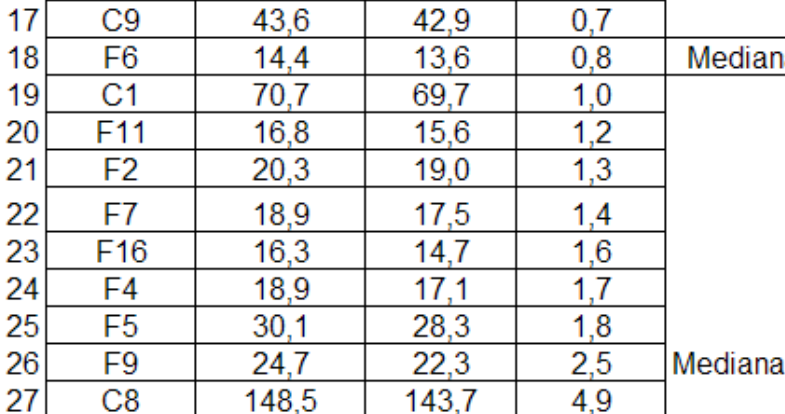

$\left.{ }^{*}\right) \mathrm{Xi}$ e $\mathrm{Yi}=$ valores de consumo médio em $\mathrm{m}^{5} / \mathrm{mês} /$ ligação

(*z) F1 a F15 = áreas com VRP Fixa; C1 a C10 = áreas com VRP Automática

Dessa análise constata-se que os consumos médios das áreas de VRP C8 e C10, foram classificados como "outliers" devendo ser descartados nas análises. Posição

\begin{tabular}{|c|c|c|}
\hline \multicolumn{3}{|c|}{ Posição } \\
\hline $1 \mathrm{Q}=$ & 7,3 & $-0,2$ \\
\hline $2 \mathrm{Q}=$ & 14,0 & 0,5 \\
\hline $3 Q=$ & 20,8 & 1,3 \\
\hline $4 \mathrm{Q}=$ & 27,5 & 4,9 \\
\hline$\| Q=$ & 1,5 & \\
\hline $\mathrm{L} 1=$ & $1 \mathrm{Q}-1,5 \| \mathrm{Q}:$ & $-2,5$ \\
\hline $\mathrm{L} 2=$ & $1 \mathrm{Q}-3,0 \| \mathrm{Q}:$ & $-4,7$ \\
\hline $\mathrm{U} 1=$ & $3 \mathrm{Q}+1,5 \| \mathrm{Q}$ & 3,6 \\
\hline $\mathrm{U} 2=$ & $3 \mathrm{Q}+3,0 \| \mathrm{Q}$ & 5,8 \\
\hline \multicolumn{3}{|c|}{0,5} \\
\hline onde: & \\
\hline $1 Q=$ & \multicolumn{2}{|c|}{ ( $1^{\circ}$ quartil) } \\
\hline $2 \mathrm{Q}=$ & \multicolumn{2}{|c|}{ ( $2^{\circ}$ quartil) } \\
\hline $3 Q=$ & \multicolumn{2}{|c|}{ ( $3^{\circ}$ quartil) } \\
\hline $4 Q=$ & \multicolumn{2}{|c|}{ ( $4^{\circ}$ quartil) } \\
\hline$\| \mathrm{Q}=$ & \multicolumn{2}{|c|}{ (intervalo interquartil) } \\
\hline $\mathrm{L} 1=$ & \multirow{2}{*}{\multicolumn{2}{|c|}{$\begin{array}{l}\text { grade interna inferior } \\
\text { grade externa inferior }\end{array}$}} \\
\hline $\mathrm{L} 2=$ & & \\
\hline $\mathrm{U} 1=$ & \\
\hline $\mathrm{U} 2=$ & \multicolumn{2}{|c|}{$\begin{array}{l}\text { grade interna superior } \\
\text { grade externa superior }\end{array}$} \\
\hline
\end{tabular}


ANÁLISE 2: ÁREAS DE VRP (2)

BOX-PLOT COM CERCAS, DOS VALORES DE CONSUMO MÉDIO NAS ÁREAS DE VRP, PARA IDENTIFICAÇÃO DE OUTLIERS

\begin{tabular}{|c|c|c|c|c|c|c|c|c|c|}
\hline & VRP & ANTES $(\mathrm{Xi})$ & APÓS (Yi) & $(\mathrm{Xi}-\mathrm{Yi})$ & \multirow{11}{*}{$\begin{array}{c}\text { Classe } \\
1 \\
2 \\
3 \\
4 \\
5\end{array}$} & \multirow{4}{*}{$\begin{array}{l}\text { MÉDIA: } \\
\text { AMPLITUDE: } \\
\text { N CLASSES: } \\
\text { FAIXA: }\end{array}$} & 0 & & \\
\hline 1 & F15 & 20,1 & 22,3 & $-2,3$ & & & & & \\
\hline 2 & C5 & 16,8 & 17,8 & $-1,0$ & & & & & \\
\hline 3 & F13 & 22,9 & 23,4 & $-0,5$ & & & & & \\
\hline 4 & C6 & 16,3 & 16,9 & $-0,5$ & & & & & \\
\hline 5 & F14 & 20,3 & 20,8 & $-0,5$ & & Consumo & ni & fi & fac \\
\hline 6 & F8 & 26,1 & 26,3 & $-0,2$ & & $-2,5 a-1,5$ & 1 & 0,04 & 0,04 \\
\hline 7 & $\mathrm{~F} 12$ & 18,8 & 18,9 & $-0,1$ & & $-1,5 a-0,5$ & 1 & 0,04 & 0,08 \\
\hline 8 & F1 & 15,8 & 16,0 & $-0,1$ & & $-0,5$ a 0,5 & 9 & 0,36 & 0,44 \\
\hline 9 & C7 & 18,8 & 18,7 & 0,2 & & 0,5 a 1,5 & 10 & 0,40 & 0,84 \\
\hline 10 & F3 & 17,3 & 17,0 & 0,2 & & 1,5 a 2,5 & 4 & 0,16 & 1,00 \\
\hline 11 & C4 & 26,7 & 26,4 & 0,3 & & soma $=$ & 25 & & \\
\hline
\end{tabular}

onde: $n i=n^{0}$ de ocorrências em cada classe de consumo $\mathrm{fi}=$ freqüência relativa do $\mathrm{n}^{0}$ de ocorrência/classe fac $=$ freqüência acumulada do $n^{0}$ de ocorrências

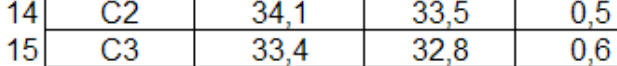
\begin{tabular}{l|l|l|l|l|}
\cline { 2 - 4 } 16 & C9 & 43,6 & 42,9 & 0,7 \\
\hline & & 14,4 & 13,6 & 0,8
\end{tabular}

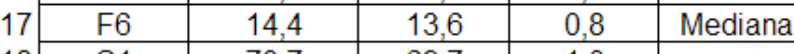
Posição

\begin{tabular}{l|l|l|l|l}
\cline { 2 - 4 } 18 & $\mathrm{C} 1$ & 70,7 & 69,7 & 1,0 \\
\cline { 2 - 5 } 19 & $\mathrm{~F} 11$ & 16,8 & 15,6 & 1,2 \\
\hline
\end{tabular}

\begin{tabular}{l|l|l|l|r|}
20 & $F 11$ & 16,8 & 15,6 & 1,2 \\
\cline { 2 - 5 } 21 & $F 2$ & 20,3 & 19,0 & 1,3 \\
\cline { 2 - 5 } & $F 7$ & 18.9 & 17.5 & 1.4
\end{tabular}

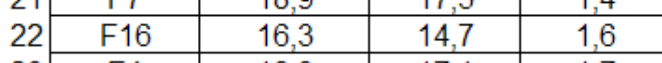

\begin{tabular}{|l|l|l|l|l|}
\cline { 2 - 5 } 23 & $\mathrm{~F} 4$ & 18,9 & 17,1 & 1,7 \\
\cline { 2 - 5 } 24 & $\mathrm{~F} 5$ & 30,1 & 28,3 & 1,8 \\
\hline
\end{tabular}

25 24,7

22,3

2,5

(*) $\mathrm{Xie} \mathrm{Yi}=$ valores de consumo médio $\mathrm{em} \mathrm{m³/mês/ligação}$

(**) F1 a F17 = áreas com VRP Fixa; C1 a C10 = áreas com VRP Automática

Dessa análise constata-se que os consumos médios da área de VRP F15 foram classificados como "outliers" devendo ser descartados nas análises.

\begin{tabular}{|c|c|c|}
\hline $1 \mathrm{Q}=$ & 6,8 & $-0,1$ \\
\hline $2 \mathrm{Q}=$ & 13,0 & 0,5 \\
\hline $3 Q=$ & 19,3 & 1,2 \\
\hline $4 Q=$ & 25,5 & 2,5 \\
\hline$\| \mathrm{Q}=$ & 1,3 & \\
\hline $\mathrm{L} 1=$ & $1 \mathrm{Q}-1,5 \| \mathrm{Q}$ & $-2,1$ \\
\hline $\mathrm{L} 2=$ & $1 \mathrm{Q}-3,0 \| \mathrm{Q}$ & $-4,0$ \\
\hline $\mathrm{U} 1=$ & $3 Q+1,5 \| Q$ & 3,2 \\
\hline $\mathrm{U} 2=$ & $3 \mathrm{Q}+3,0 \| \mathrm{Q}$ & 5,1 \\
\hline onde: & \multirow{2}{*}{\multicolumn{2}{|c|}{ ( $1^{\circ}$ quartil) }} \\
\hline $1 \mathrm{Q}=$ & & \\
\hline $2 \mathrm{Q}=$ & \multicolumn{2}{|c|}{ ( $2^{\circ}$ quartil) } \\
\hline $3 Q=$ & \multicolumn{2}{|c|}{ ( $3^{\circ}$ quartil) } \\
\hline $4 Q=$ & \multicolumn{2}{|c|}{ ( $4^{\circ}$ quartil) } \\
\hline$\| \mathrm{Q}=$ & \multicolumn{2}{|c|}{ (intervalo interquartil) } \\
\hline $\mathrm{L} 1=$ & \multicolumn{2}{|c|}{ grade interna inferior } \\
\hline $\mathrm{L} 2=$ & \multicolumn{2}{|c|}{ grade externa inferior } \\
\hline $\mathrm{U} 1=$ & \multicolumn{2}{|c|}{ grade interna superior } \\
\hline $\mathrm{U} 2=$ & grade exter & perior \\
\hline
\end{tabular}


ANÁLISE 2: ÁREAS DE VRP (3)

BOX-PLOT COM CERCAS, DOS VALORES DE CONSUMO MÉDIO NAS ÁREAS DE VRP, PARA IDENTIFICAÇÃO DE OUTLIERS

\begin{tabular}{|c|c|c|c|c|c|c|c|c|c|}
\hline & VRP & ANTES (Xi) & APÓS (Yi) & $(X i-Y i)$ & & \multirow{4}{*}{$\begin{array}{l}\text { MÉDIA: } \\
\text { AMPLITUDE: } \\
\text { N CLASSES: } \\
\text { FAIXA: }\end{array}$} & \multicolumn{2}{|c|}{0.6} & \\
\hline 1 & C5 & 16,8 & 17,8 & $-1,0$ & & & & & \\
\hline 2 & F13 & 22,9 & 23,4 & $-0,5$ & & & & & \\
\hline 3 & C6 & 16,3 & 16,9 & $-0,5$ & & & & & \\
\hline 4 & F14 & 20,3 & 20,8 & $-0,5$ & & & & & \\
\hline 5 & F8 & 26,1 & 26,3 & $-0,2$ & & & & & \\
\hline 6 & F12 & 18,8 & 18,9 & $-0,1$ & Classe & Consumo & ni & fi & fac \\
\hline 7 & $\mathrm{~F} 1$ & 15,8 & 16,0 & $-0,1$ & 1 & $-1,0$ a $-0,3$ & 4 & 0,17 & 0,17 \\
\hline 8 & C7 & 18,8 & 18,7 & 0,2 & 2 & $-0,3$ a 0,4 & 6 & 0,25 & 0,42 \\
\hline 9 & F3 & 17,3 & 17,0 & 0,2 & 3 & 0,4 a 1,1 & 7 & 0,29 & 0,71 \\
\hline 10 & $\mathrm{C} 4$ & 26,7 & 26,4 & 0,3 & 4 & 1,1 a 1,8 & 6 & 0,25 & 0,96 \\
\hline 11 & $\mathrm{~F} 10$ & 43,9 & 43,4 & 0,5 & 5 & 1,8 a 2,5 & 1 & 0,04 & 1,00 \\
\hline 12 & F17 & 14,7 & 14,2 & 0,5 & & soma $=$ & 24 & & \\
\hline
\end{tabular}

onde: $n i=n^{0}$ de ocorrências em cada classe de consumo $\mathrm{fi}=$ freqüência relativa do $\mathrm{n}^{0}$ de ocorrência/classe fac $=$ freqüência acumulada do $n^{0}$ de ocorrências

\begin{tabular}{r|c|r|r|r}
\cline { 3 - 5 } 16 & $\mathrm{~F} 6$ & 14,4 & 13,6 & 0,8 \\
\cline { 2 - 5 } 17 & $\mathrm{C} 1$ & 70,7 & 69,7 & 1,0 \\
\cline { 2 - 5 } 18 & $\mathrm{~F} 11$ & 16,8 & 15,6 & 1,2 \\
\cline { 2 - 5 } 19 & $\mathrm{~F} 2$ & 20,3 & 19,0 & 1,3 \\
\cline { 2 - 5 } 20 & $\mathrm{~F} 7$ & 18,9 & 17,5 & 1,4 \\
\cline { 2 - 5 } 21 & $\mathrm{~F} 16$ & 16,3 & 14,7 & 1,6 \\
\cline { 2 - 5 } 22 & $\mathrm{~F} 4$ & 18,9 & 17,1 & 1,7 \\
\cline { 3 - 5 } 23 & $\mathrm{~F} 5$ & 30,1 & 28,3 & 1,8 \\
\cline { 3 - 5 } 24 & $\mathrm{~F} 9$ & 24,7 & 22,3 & 2,5 \\
\hline
\end{tabular}

(*) $\mathrm{Xie} \mathrm{Yi}$ = valores de consumo médio em ms/mês/ligação

${ }^{(* *)}$ F1 a F15 = áreas com VRP Fixa; C1 a C10 = áreas com VRP Automática
Dessa análise constata-se que os consumos médios das áreas de VRP relacionadas não apresentam "outliers".

-

trecer

Mediana

Median

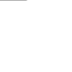

ediana:

\begin{tabular}{rrr} 
& \multicolumn{3}{c}{ Posição } \\
$1 \mathrm{Q}=$ & 6,5 & $-0,1$ \\
$2 \mathrm{Q}=$ & 12,5 & 0,5 \\
$3 \mathrm{Q}=$ & 18,5 & 1,2 \\
$4 \mathrm{Q}=$ & 24,5 & 2,5 \\
$\mathrm{IQ}=$ & 1,3 & \\
$\mathrm{~L} 1=$ & $1 \mathrm{Q}-1,5 \| \mathrm{Q}:$ & $-2,1$ \\
$\mathrm{~L} 2=$ & $1 \mathrm{Q}-3,0 \| \mathrm{Q}:$ & -4 \\
$\mathrm{U} 1=$ & $3 \mathrm{Q}+1,5 \| \mathrm{Q}$ & 3,2 \\
$\mathrm{U} 2=$ & $3 \mathrm{Q}+3,0 \| \mathrm{Q}$ & 5,1
\end{tabular}

onde:

$\begin{array}{lc}1 \mathrm{Q}= & \left(1^{\circ} \text { quartil }\right) \\ 2 \mathrm{Q}= & \left(2^{\circ} \text { quartil }\right) \\ 3 \mathrm{Q}= & \left(3^{\circ} \text { quartil }\right) \\ 4 \mathrm{Q}= & \left(4^{\circ} \text { quartil }\right) \\ \mathrm{IQ}= & \text { (intervalo interquartil) } \\ \mathrm{L} 1= & \text { grade interna inferior } \\ \mathrm{L} 2= & \text { grade externa inferior } \\ \mathrm{U} 1= & \text { grade interna superior } \\ \mathrm{U} 2= & \text { grade externa superior }\end{array}$


ANÁLISE 3: ÁREAS TESTEMUNHA DE ÁREA DE VRP (2)

BOX-PLOT COM CERCAS, DOS VALORES DE CONSUMO MÉDIO NAS ÁREAS DE VRP, PARA IDENTIFICAÇÃO DE OUTLIERS

\begin{tabular}{|c|c|c|c|c|c|c|c|c|c|}
\hline & VRP & ANTES $(\mathrm{Xi})$ & APÓS (Yi) & $(X i-Y i)$ & \multirow{13}{*}{$\begin{array}{c}\text { Classe } \\
1 \\
2 \\
3 \\
4 \\
5\end{array}$} & \multirow{6}{*}{$\begin{array}{l}\text { MÉDIA: } \\
\text { AMPLITUDE: } \\
\text { N CLASSES: } \\
\text { FAIXA: }\end{array}$} & \multicolumn{2}{|c|}{0,5} & \\
\hline 1 & F14 Test. & 48,5 & 50,2 & $-1,8$ & & & \multicolumn{2}{|c|}{5,3} & \\
\hline 2 & F15 Test. & 13,0 & 14,1 & $-1,2$ & & & \multicolumn{2}{|c|}{5} & \\
\hline 3 & C6 Test. & 16,6 & 17,6 & $-1,0$ & & & \multicolumn{2}{|c|}{1,1} & \\
\hline 4 & C5 Test. & 16,8 & 17,6 & $-0,8$ & & & & & \\
\hline 5 & C1 Test. & 36,1 & 36,8 & $-0,7$ & & & & & \\
\hline 6 & C2 Test. & 88,0 & 88,1 & $-0,2$ & & Consumo & ni & fi & fac \\
\hline 7 & C7 Test. & 19,3 & 19,3 & $-0,1$ & & $-1,8$ a $-0,7$ & 4 & 0,16 & 0,16 \\
\hline 8 & F1 Test. & 15,9 & 15,8 & 0,1 & & $-0,7$ a 0,4 & 7 & 0,28 & 0,44 \\
\hline 9 & F3 Test. & 17,2 & 17,0 & 0,2 & & 0,4 a 1,5 & 8 & 0,32 & 0,76 \\
\hline 10 & F17 Test. & 14,3 & 14,0 & 0,2 & & 1,5 a 2,6 & 5 & 0,20 & 0,96 \\
\hline 11 & C9 Test. & 38,9 & 38,6 & 0,3 & & 2,6 a 3,7 & 1 & 0,04 & 1,00 \\
\hline 12 & F9 Test. & 22,2 & 21,7 & 0,5 & & soma $=$ & 25 & & \\
\hline & & & & & & & & & \\
\hline
\end{tabular}

onde: $n i=n^{\circ}$ de ocorrências em cada classe de consumo $\mathrm{fi}=$ freqüência relativa do $\mathrm{n}^{0}$ de ocorrência/classe fac $=$ freqüência acumulada do $n^{0}$ de ocorrências

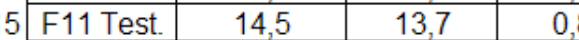

\begin{tabular}{l|l|l|l|l}
16 & C4 Test. & 30,0 & 29,0 & 1,0 \\
\hline
\end{tabular}

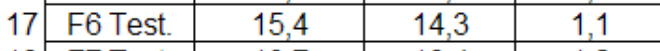

18 \begin{tabular}{c|r}
\hline F7 Test. & 19,7 \\
\cline { 2 - 3 } & F4 Test. \\
\hline
\end{tabular}

19 F4 Test. 19,7

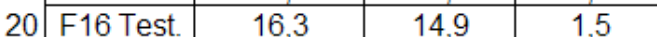

21 F10 Test. 43,6

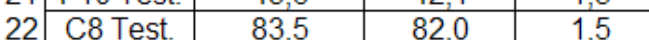

23 F13 Test. $\quad 54,2$

24 F12 Test. 22,6

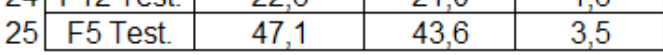

(*) $\mathrm{Xi}$ e Yi = valores de consumo médio em m³/mês/ligação

${ }^{(* z)}$ F1 Test a F15 Test = áreas testemunha de VRP Fixa

${ }^{(* * x)}$ C1 Test a C10 Test = áreas testemunha de VRP Automática

\begin{tabular}{|c|c|c|c|c|c|}
\hline & \multicolumn{3}{|c|}{ Posição } & \multicolumn{2}{|c|}{ onde: } \\
\hline & $1 Q=$ & 6,8 & $-0,1$ & $1 \mathrm{Q}=$ & ( $1^{\circ}$ quartil) \\
\hline Mediana: & $2 Q=$ & 13,0 & 0,6 & $2 \mathrm{Q}=$ & ( $2^{\circ}$ quartil) \\
\hline & $3 Q=$ & 19,3 & 1,3 & $3 \mathrm{Q}=$ & ( $3^{\circ}$ quartil) \\
\hline & $4 Q=$ & 25,5 & 3,5 & $4 Q=$ & ( $4^{\circ}$ quartil) \\
\hline & $\| Q=$ & 1,4 & & $\| \mathrm{Q}=$ & (intervalo interquartil) \\
\hline & $\mathrm{L} 1=$ & $1 \mathrm{Q}-1,5 \| \mathrm{Q}:$ & $-2,2$ & $\mathrm{~L} 1=$ & grade interna inferior \\
\hline & $\mathrm{L} 2=$ & $1 \mathrm{Q}-3,0 \| \mathrm{Q}:$ & $-4,3$ & $\mathrm{~L} 2=$ & grade externa inferior \\
\hline & $\mathrm{U} 1=$ & $3 \mathrm{Q}+1,5 \| \mathrm{Q}$ & 3,4 & $\mathrm{U} 1=$ & grade interna superior \\
\hline & $\mathrm{U} 2=$ & $3 \mathrm{Q}+3,0 \| \mathrm{Q}$ & 5,5 & $\mathrm{U} 2=$ & grade externa superior \\
\hline
\end{tabular}

Dessa análise constata-se que os consumos médios da área Testemunha F5 foram classificados como "outliers" (fora dos limites da cerca interna inferior do "box-plot"), devendo ser descartados nas análises. 
ANÁLISE 3: ÁREAS TESTEMUNHA DE ÁREA DE VRP (3)

BOX-PLOT COM CERCAS, DOS VALORES DE CONSUMO MÉDIO NAS ÁREAS DE VRP, PARA IDENTIFICAÇÃO DE OUTLIERS

\begin{tabular}{|c|c|c|c|c|c|c|c|c|c|}
\hline & VRP & ANTES (Xi) & APÓS (Yi) & $(X i-Y i)$ & \multirow{13}{*}{$\begin{array}{c}\text { Classe } \\
1 \\
2 \\
3 \\
4 \\
5\end{array}$} & \multirow{6}{*}{$\begin{array}{l}\text { MÉDIA: } \\
\text { AMPLITUDE: } \\
\text { № CLASSES: } \\
\text { FAIXA: }\end{array}$} & \multicolumn{2}{|c|}{0,4} & \\
\hline 1 & F14 Test. & 48,5 & 50,2 & $-1,8$ & & & & & \\
\hline 2 & F15 Test. & 13,0 & 14,1 & $-1,2$ & & & & & \\
\hline 3 & C6 Test. & 16,6 & 17,6 & $-1,0$ & & & & & \\
\hline 4 & C5 Test. & 16,8 & 17,6 & $-0,8$ & & & & & \\
\hline 5 & C1 Test. & 36,1 & 36,8 & $-0,7$ & & & & & \\
\hline 6 & C2 Test. & 88,0 & 88,1 & $-0,2$ & & Consumo & ni & fi & fac \\
\hline 7 & C7 Test. & 19,3 & 19,3 & $-0,1$ & & $-1,8 \mathrm{a}-1,1$ & 2 & 0,08 & 0,08 \\
\hline 8 & F1 Test. & 15,9 & 15,8 & 0,1 & & $-1,1$ a $-0,3$ & 3 & 0,13 & 0,21 \\
\hline 9 & F3 Test. & 17,2 & 17,0 & 0,2 & & $-0,3$ a 0,4 & 6 & 0,25 & 0,46 \\
\hline 10 & F17 Test. & 14,3 & 14,0 & 0,2 & & 0,4 a 1,1 & 5 & 0,21 & 0,67 \\
\hline 11 & C9 Test. & 38,9 & 38,6 & 0,3 & & 1,1 a 1,8 & 8 & 0,33 & 1,00 \\
\hline 12 & F9 Test. & 22,2 & 21,7 & 0,5 & & soma $=$ & 24 & & \\
\hline
\end{tabular}

onde: $n i=n^{0}$ de ocorrências em cada classe de consumo $\mathrm{fi}=$ freqüência relativa do $\mathrm{n}^{0}$ de ocorrência/classe fac $=$ frequêencia acumulada do $n^{0}$ de ocorrências 


\section{ANÁLISE 4: ÁREAS DE VRP COM SAÍDA FIXA DE PRESSÃO}

\section{BOX-PLOT COM GRADES, DOS VALORES DE CONSUMO MÉDIO NAS ÁREAS DE VRP, PARA IDENTIFICAÇÃO DE OUTLIERS}

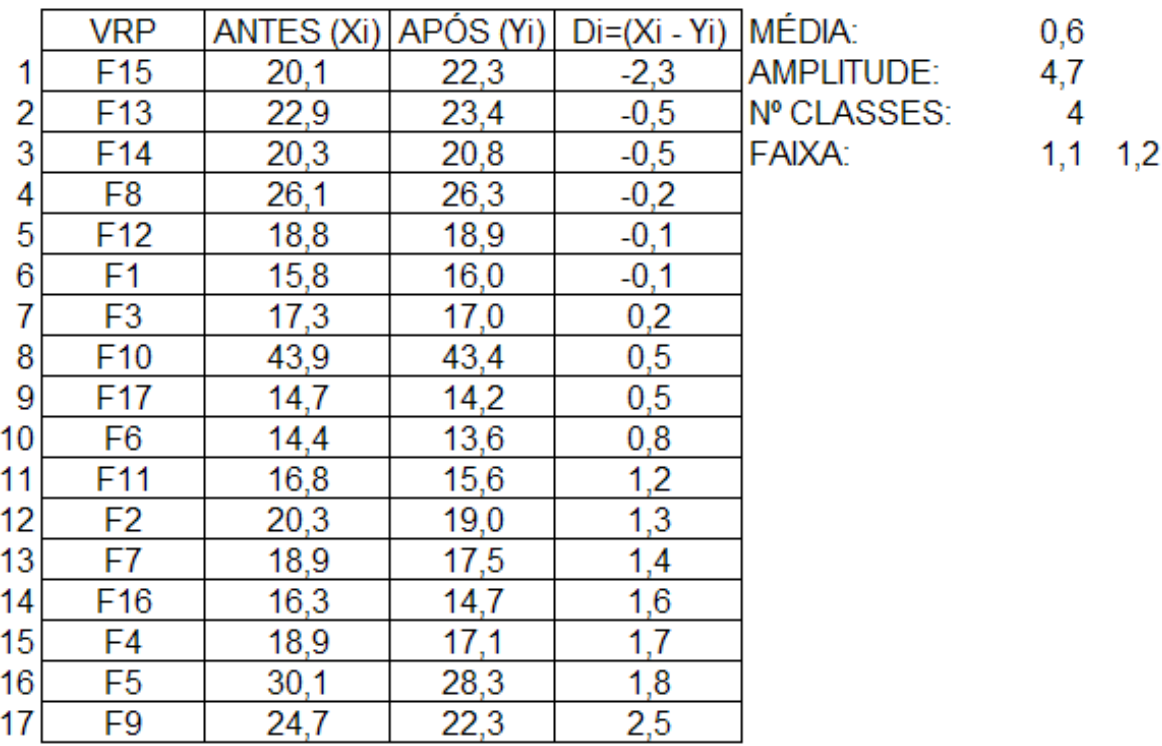

${ }^{*}$ ) $\mathrm{Xi} \mathrm{e} \mathrm{Yi}=$ valores de consumo médio em $\mathrm{m}^{2} / \mathrm{mês} /$ ligação

$\left.{ }^{* *}\right)$ F1 a F15 = áreas com VRP Fixa

$\begin{array}{ccccc}\text { Classe } & \text { Consumo } & \text { ni } & \text { fi } & \text { fac } \\ 1 & -2,3 \text { a }-1,1 & 1 & 0,06 & 0,06 \\ 2 & -1,1 \text { a } 0,1 & 5 & 0,29 & 0,35 \\ 3 & 0,1 \text { a } 1,3 & 5 & 0,29 & 0,65 \\ 4 & 1,3 \text { a } 2,5 & 6 & 0,35 & 1,00 \\ & \text { soma }= & 17 & & \end{array}$

onde: $\mathrm{ni}=\mathrm{n}^{0}$ de ocorrências em cada classe de consumo

$\mathrm{fi}=$ freqüência relativa do $\mathrm{n}^{0}$ de ocorrência/classe

fac $=$ freqüência acumulada do $n^{0}$ de ocorrências

\begin{tabular}{|c|c|c|c|c|}
\hline & & Posição & Valor & \\
\hline & $1 \mathrm{Q}=$ & 4,8 & $-0,1$ & ( $1^{\circ}$ quartil) \\
\hline Mediana: & $2 Q=$ & 9,0 & 0,5 & ( $2^{\circ}$ quartil) \\
\hline & $3 \mathrm{Q}=$ & 13,3 & 1,4 & ( $3^{\circ}$ quartil) \\
\hline & $4 \mathrm{Q}=$ & 17,5 & 2,5 & ( $4^{\circ}$ quartil) \\
\hline & $\| \mathrm{Q}=$ & $3 Q-1 Q=$ & 1,5 & (intervalo interquartil) \\
\hline & $\mathrm{L} 1=$ & $1 \mathrm{Q}-1,5 \| \mathrm{Q}=$ & $-2,4$ & grade interna inferior \\
\hline & $\mathrm{L} 2=$ & $1 \mathrm{Q}-3,0 \| \mathrm{Q}=$ & $-4,6$ & grade externa inferior \\
\hline & $\mathrm{U} 1=$ & $3 \mathrm{Q}+1,5 \| \mathrm{Q}=$ & 3,7 & grade interna superior \\
\hline & $\mathrm{U} 2=$ & $3 \mathrm{Q}+3.0 \| \mathrm{Q}=$ & 5,9 & grade externa superior \\
\hline
\end{tabular}

Dessa análise constata-se que os consumos médios das áreas de VRP com controle fixo de saida não apresentam "outliers" (toda a série de valores se encontra entre os limites das grades internas: entre $-2,4$ e 3,7 ). 


\section{ANÁLISE 4.1: ÁREAS DE VRP FIXA (até 12 econ./Lig.)}

\section{BOX-PLOT COM CERCAS, DOS VALORES DE CONSUMO MÉDIO NAS ÁREAS DE VRP, PARA IDENTIFICAÇÃO DE OUTLIERS}

\begin{tabular}{|c|c|c|c|c|c|c|}
\hline & VRP & ANTES (Xi) & APÓS (Yi) & $\mathrm{Di}=(\mathrm{Xi}-\mathrm{Yi})$ & MÉDIA: & 0,6 \\
\hline 1 & F15 & 13,5 & 15,3 & $-1,8$ & AMPLITUDE: & 4,3 \\
\hline 2 & F13 & 22,9 & 23,4 & $-0,5$ & $N^{\circ}$ CLASSES: & 4 \\
\hline 3 & F14 & 20,3 & 20,8 & $-0,5$ & FAIXA: & 1,01 \\
\hline 4 & F8 & 26,1 & 26,3 & $-0,2$ & & \\
\hline 5 & F1 & 15,8 & 16,0 & $-0,1$ & & \\
\hline 6 & F12 & 18,8 & 18,9 & $-0,1$ & & \\
\hline 7 & F3 & 17,3 & 17,0 & 0,2 & & \\
\hline 8 & F17 & 14,7 & 14,2 & 0,5 & & \\
\hline 9 & F6 & 14,4 & 13,6 & 0,8 & & \\
\hline 10 & F11 & 16,8 & 15,6 & 1,2 & & \\
\hline 11 & F2 & 20,2 & 18,9 & 1,3 & & \\
\hline 12 & F5 & 26,6 & 25,2 & 1,4 & & \\
\hline 13 & F7 & 18,9 & 17,5 & 1,4 & & \\
\hline 14 & F10 & 38,5 & 37,0 & 1,5 & & \\
\hline 15 & F16 & 16,3 & 14,7 & 1,6 & & \\
\hline 16 & F4 & 18,9 & 17,1 & 1,7 & & \\
\hline 17 & F9 & 24,1 & 21,6 & 2,5 & & \\
\hline
\end{tabular}

$\left.{ }^{*}\right) \mathrm{Xi}$ e $\mathrm{Yi}=$ valores de consumo médio $\mathrm{em} \mathrm{m}^{3} / \mathrm{mês} /$ ligação

(**) F1 a F15 = áreas com VRP Fixa

$\begin{array}{ccccc}\text { Classe } & \text { Consumo } & \text { ni } & \text { fi } & \text { fac } \\ 1 & -1,8 \text { a }-0,7 & 1 & 0,06 & 0,06 \\ 2 & -0,7 \text { a } 0,4 & 6 & 0,35 & 0,41 \\ 3 & 0,4 \text { a } 1,5 & 6 & 0,35 & 0,76 \\ 4 & 1,5 \text { a } 2,6 & 4 & 0,24 & 1,00 \\ & \text { soma }= & 17 & & \end{array}$

onde: $\mathrm{ni}=\mathrm{n}^{0}$ de ocorrências em cada classe de consumo $\mathrm{fi}=$ freqüência relativa do $n^{0}$ de ocorrência/classe fac $=$ freqüência acumulada do $n^{\circ}$ de ocorrências

\begin{tabular}{rrrrr} 
& \multicolumn{2}{c}{ Posição } & Valor & \\
\hline Mediana: & $1 \mathrm{Q}=$ & 4,8 & $-0,1$ & $\left(1^{\circ}\right.$ quartil) \\
\hline $\mathrm{Q}=$ & 9,0 & 0,8 & $\left(2^{\circ}\right.$ quartil) \\
& $3 \mathrm{Q}=$ & 13,3 & 1,4 & $\left(3^{\circ}\right.$ quartil) \\
$4 \mathrm{Q}=$ & 17,5 & 2,5 & $\left(4^{\circ}\right.$ quartil) \\
$\mathrm{IQ}=$ & 1,5 & & (intervalo interquartil) \\
& & & & \\
$\mathrm{L} 1=$ & $1 \mathrm{Q}-1,5 \| \mathrm{Q}=$ & $-2,4$ & grade interna inferior \\
$\mathrm{L} 2=$ & $1 \mathrm{Q}-3,0 \| \mathrm{Q}=$ & $-4,6$ & grade externa inferior \\
$\mathrm{U} 1=$ & $3 \mathrm{Q}+1,5 \| \mathrm{Q}=$ & 3,7 & grade interna superior \\
$\mathrm{U} 2=$ & $3 \mathrm{Q}+3,0 \| \mathrm{Q}=$ & 5,9 & grade externa superior
\end{tabular}

Dessa análise constata-se que os consumos médios das áreas de VRP com controle fixo de saída não apresentam "outliers". 


\section{ANÁLISE 4.2: ÁREAS DE VRP FIXA (até 3 econ./Lig.)}

\section{BOX-PLOT COM CERCAS, DOS VALORES DE CONSUMO MÉDIO NAS ÁREAS DE VRP, PARA IDENTIFICAÇÃO DE OUTLIERS}

\begin{tabular}{|c|c|c|c|c|c|c|}
\hline & VRP & ANTES (Xi) & APÓS (Yi) & $\mathrm{Di}=(\mathrm{Xi}-\mathrm{Yi})$ & MÉDIA: & 0,6 \\
\hline 1 & F15 & 13,5 & 15,3 & $-1,8$ & AMPLITUDE: & 4,3 \\
\hline 2 & F13 & 21,8 & 22,2 & $-0,4$ & $N^{0}$ CLASSES: & 4 \\
\hline 3 & F14 & 20,0 & 20,4 & $-0,4$ & FAIXA: & 1,01 \\
\hline 4 & F8 & 26,2 & 26,4 & $-0,3$ & & \\
\hline 5 & $\mathrm{~F} 1$ & 15,6 & 15,8 & $-0,1$ & & \\
\hline 6 & F12 & 18,5 & 18,6 & $-0,1$ & & \\
\hline 7 & F3 & 17,3 & 17,0 & 0,2 & & \\
\hline 8 & F17 & 14,7 & 14,2 & 0,5 & & \\
\hline 9 & F6 & 14,4 & 13,6 & 0,8 & & \\
\hline 10 & F11 & 16,5 & 15,3 & 1,2 & & \\
\hline 11 & F2 & 19,5 & 18,2 & 1,3 & & \\
\hline 12 & F5 & 26,6 & 25,2 & 1,4 & & \\
\hline 13 & $\mathrm{~F} 10$ & 36,5 & 35,1 & 1,4 & & \\
\hline 14 & F7 & 18,7 & 17,2 & 1,4 & & \\
\hline 15 & F16 & 16,3 & 14,7 & 1,6 & & \\
\hline 16 & $\mathrm{~F} 4$ & 18,3 & 16,6 & 1,7 & & \\
\hline 17 & F9 & 24,1 & 21,6 & 2,5 & & \\
\hline
\end{tabular}

$\left.{ }^{*}\right) \mathrm{Xi}$ e $\mathrm{Yi}=$ valores de consumo médio $\mathrm{em} \mathrm{m}^{3} / \mathrm{mês} /$ ligação

${ }^{(* *)}$ F1 a F15 = áreas com VRP Fixa

$\begin{array}{ccccc}\text { Classe } & \text { Consumo } & \text { ni } & \text { fi } & \text { fac } \\ 1 & -1,8 \text { a }-0,7 & 1 & 0,06 & 0,06 \\ 2 & -0,7 \text { a } 0,4 & 6 & 0,35 & 0,41 \\ 3 & 0,4 \text { a } 1,5 & 7 & 0,41 & 0,82 \\ 4 & 1,5 \text { a } 2,6 & 3 & 0,18 & 1,00 \\ & \text { soma }= & 17 & & \end{array}$

onde: $\mathrm{ni}=\mathrm{n}^{\circ}$ de ocorrências em cada classe de consumo

$\mathrm{fi}=$ freqüência relativa do $\mathrm{n}^{0}$ de ocorrência/classe

fac = frequêencia acumulada do $n^{0}$ de ocorrências

\begin{tabular}{rrrr} 
& \multicolumn{2}{c}{ Posição } \\
\hline Mediana: & $2 \mathrm{Q}=$ & 4,8 & $-0,1$ \\
\hline $3 \mathrm{Q}=$ & 13,0 & 0,8 \\
$\mathrm{4Q}=$ & 17,3 & 1,4 \\
$\mathrm{IQ}=$ & 1,5 & 2,5 \\
& & \\
$\mathrm{~L} 1=$ & $1 \mathrm{Q}-1,5 \| \mathrm{Q}=$ & $-2,4$ \\
$\mathrm{~L} 2=$ & $1 \mathrm{Q}-3,0 \| \mathrm{Q}=$ & $-4,6$ \\
$\mathrm{U} 1=$ & $3 \mathrm{Q}+1,5 \| \mathrm{Q}=$ & 3,7 \\
$\mathrm{U} 2=$ & $3 \mathrm{Q}+3,0 \| \mathrm{Q}=$ & 5,9
\end{tabular}

Mediana:

Dessa análise constata-se que os consumos médios das áreas de VRP com controle fixo de saida não apresentam "outliers". 
ANÁLISE 4.3: ÁREAS DE VRP FIXA (1 econ./Lig.)

BOX-PLOT COM CERCAS, DOS VALORES DE CONSUMO MÉDIO NAS ÁREAS DE VRP, PARA IDENTIFICAÇÃO DE OUTLIERS

\begin{tabular}{|c|c|c|c|c|c|}
\hline & VRP & ANTES (Xi) & APÓS (Yi) & $\mathrm{Di}=(\mathrm{Xi}-\mathrm{Yi})$ & MÉDIA: \\
\hline 1 & F15 & 12,8 & 14,4 & $-1,7$ & AMPLITUDE: \\
\hline 2 & F13 & 19,8 & 20,1 & $-0,3$ & $\mathrm{~N}^{\circ} \mathrm{CLASSES}$ \\
\hline 3 & F14 & 19,5 & 19,8 & $-0,3$ & FAIXA: \\
\hline 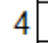 & F12 & 17,4 & 17,7 & $-0,3$ & \\
\hline 5 & $\mathrm{~F} 1$ & 13,9 & 14,1 & $-0,2$ & \\
\hline 6 & F8 & 26,0 & 26,2 & $-0,2$ & \\
\hline 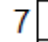 & F3 & 17,3 & 17,0 & 0,2 & \\
\hline 8 & F17 & 13,9 & 13,3 & 0,6 & \\
\hline 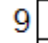 & F6 & 13,8 & 13,1 & 0,7 & \\
\hline 10 & F11 & 14,6 & 13,6 & 1,0 & \\
\hline 11 & F16 & 15,0 & 13,9 & 1,1 & \\
\hline 12 & $\mathrm{~F} 2$ & 18,0 & 16,7 & 1,3 & \\
\hline 13 & F7 & 17,8 & 16,5 & 1,3 & \\
\hline 14 & F5 & 26,4 & 25,0 & 1,4 & \\
\hline 15 & F10 & 36,4 & 35,0 & 1,4 & \\
\hline 16 & F4 & 17,1 & 15,5 & 1,6 & \\
\hline 17 & F9 & 24,3 & 21,6 & 2,7 & \\
\hline
\end{tabular}

0,6

4

1,1

$\begin{array}{ccccc}\text { Classe } & \text { Consumo } & \text { ni } & \text { fi } & \text { fac } \\ 1 & -1,7 \text { a }-0,6 & 1 & 0,06 & 0,06 \\ 2 & -0,6 \text { a } 0,5 & 6 & 0,35 & 0,41 \\ 3 & 0,5 \text { a } 1,6 & 8 & 0,47 & 0,88 \\ 4 & 1,6 \text { a } 2,7 & 2 & 0,12 & 1,00 \\ & \text { soma }= & 17 & & \end{array}$

onde: $\mathrm{ni}=\mathrm{n}^{0}$ de ocorrências em cada classe de consumo $\mathrm{fi}=$ freqüência relativa do $\mathrm{n}^{0}$ de ocorrência/classe fac $=$ freqüência acumulada do $n^{0}$ de ocorrências

\begin{tabular}{rrrr} 
& \multicolumn{3}{c}{ Posição } \\
\hline Mediana: & $2 \mathrm{Q}=$ & 4,8 & $-0,2$ \\
\hline $\mathrm{3Q}=$ & 13,0 & 0,7 \\
$\mathrm{4Q}=$ & 17,5 & 1,3 \\
$\mathrm{IQ}=$ & 1,5 & 2,7 \\
& & \\
$\mathrm{~L} 1=$ & $1 \mathrm{Q}-1,5 \| \mathrm{Q}=$ & $-2,5$ \\
$\mathrm{~L} 2=$ & $1 \mathrm{Q}-3,0 \| \mathrm{Q}=$ & $-4,7$ \\
$\mathrm{U} 1=$ & $3 \mathrm{Q}+1,5 \| \mathrm{Q}=$ & 3,6 \\
$\mathrm{U} 2=$ & $3 \mathrm{Q}+3,0 \| \mathrm{Q}=$ & 5,8
\end{tabular}

Mediana: $\quad 0,7$

Dessa análise constata-se que os consumos médios das áreas de VRP com controle fixo de saída não apresentam "outliers". 
ANÁLISE 5: ÁREAS DE VRP COM CONTROLE AUTOMÁTICO DE PRESSÃO (1) BOX-PLOT COM CERCAS, DOS VALORES DE CONSUMO MÉDIO NAS ÁREAS DE VRP, PARA IDENTIFICAÇÃO DE OUTLIERS

\begin{tabular}{|c|c|c|c|c|}
\hline & VRP & ANTES (Xi) & APÓS (Yi) & $(X i-Y i)$ \\
\hline 1 & C10 & 186,4 & 211,1 & $-24,7$ \\
\hline 2 & $\mathrm{C} 5$ & 16.8 & 17.8 & -1.0 \\
\hline 3 & C6 & 16,3 & 16,9 & $-0,5$ \\
\hline 4 & C7 & 18,8 & 18,7 & 0,2 \\
\hline 5 & C4 & 26,7 & 26,4 & 0,3 \\
\hline 6 & $\mathrm{C} 2$ & 34,1 & 33,5 & 0,5 \\
\hline 7 & C3 & 33,4 & 328 & 0,6 \\
\hline 8 & C9 & 43,6 & 42,9 & 0,7 \\
\hline 9 & C1 & 70,7 & 69,7 & 1,0 \\
\hline 10 & $\mathrm{C} 8$ & 148,5 & 143,7 & 4,9 \\
\hline
\end{tabular}
(*t) $\mathrm{C} 1$ a C10 = áreas com VRP Automática

\begin{tabular}{|c|c|c|c|}
\hline & \multicolumn{3}{|c|}{ Posição } \\
\hline & $1 \mathrm{Q}=$ & 3,0 & $-0,5$ \\
\hline Mediana & $2 Q=$ & 5,5 & 0,3 \\
\hline & $3 \mathrm{Q}=$ & 8,0 & 0,7 \\
\hline & $4 Q=$ & 10,5 & 4,9 \\
\hline & $\| \mathrm{Q}=$ & 1,2 & \\
\hline & $\mathrm{L} 1=$ & $1 \mathrm{Q}-1,5 \| \mathrm{Q}:$ & $-2,3$ \\
\hline & $\mathrm{L} 2=$ & $1 \mathrm{Q}-3,0 \| \mathrm{Q}:$ & $-4,1$ \\
\hline & $\mathrm{U} 1=$ & $3 \mathrm{Q}+1,5 \| \mathrm{Q}$ & 2,5 \\
\hline & $\mathrm{U} 2=$ & $3 \mathrm{Q}+3,0 \| \mathrm{Q}$ & 4,3 \\
\hline
\end{tabular}

$\begin{array}{lr}\text { MÉDIA: } & -1,8 \\ \text { AMPLITUDE: } & 29,6 \\ \text { N }{ }^{\circ} \text { CLASSES: } & 3 \\ \text { FAIXA: } & 9,9\end{array}$

Classe

$\begin{array}{lc}\text { Consumo } & \text { ni } \\ -24,7 \text { a }-14,8 & 1 \\ -14,8 \text { a }-4,9 & 2 \\ -4,9 \text { a } 5,0 & 7 \\ \text { soma }= & 10\end{array}$

fi fac

0,10

0,30

$0,70 \quad 1,00$

onde: $\mathrm{ni}=\mathrm{n}^{0}$ de ocorrências em cada classe de consumo $\mathrm{fi}=$ frequêencia relativa do $n^{0}$ de ocorrência/classe fac $=$ frequêencia acumulada do $n^{0}$ de ocorrências

Dessa análise constata-se que os consumos médios das áreas de VRP C8 e C10 foram classificados como "outliers" (encontram-se fora dos limites das cercas externas, superior e inferior, respectivamente), devendo ser descartados nas análises.

ANÁLISE 5: ÁREAS DE VRP COM CONTROLE AUTOMÁTICO DE PRESSÃO (2) BOX-PLOT COM CERCAS, DOS VALORES DE CONSUMO MÉDIO NAS ÁREAS DE VRP, PARA IDENTIFICAÇÃO DE OUTLIERS

\begin{tabular}{|c|c|c|c|c|}
\cline { 2 - 5 } & VRP & ANTES (Xi) & APÓS (Yi) & $(\mathrm{Xi}-\mathrm{Yi})$ \\
\cline { 2 - 5 } 1 & C5 & 16,8 & 17,8 & $-1,0$ \\
\cline { 2 - 5 } 2 & C6 & 16,3 & 16,9 & $-0,5$ \\
\cline { 2 - 5 } 3 & C7 & 18,8 & 18,7 & 0,2 \\
\hline 4 & C4 & 26,7 & 26,4 & 0,3 \\
\hline 5 & C2 & 34,1 & 33,5 & 0,5 \\
\hline 6 & C3 & 33,4 & 32,8 & 0,6 \\
\cline { 2 - 5 } 7 & C9 & 43,6 & 42,9 & 0,7 \\
\cline { 2 - 5 } 8 & C1 & 70,7 & 69,7 & 1,0 \\
\hline
\end{tabular}

$\left.{ }^{(}\right) \mathrm{Xi}$ $\mathrm{Yi}=$ valores de consumo médio em m³/mês/ligação (**) $\mathrm{C} 1$ a C10 = áreas com VRP Automática

\begin{tabular}{|c|c|c|c|}
\hline & \multicolumn{3}{|c|}{ Posição } \\
\hline & $1 \mathrm{Q}=$ & 2,5 & $-0,5$ \\
\hline Mediana & $2 Q=$ & 4,5 & 0,3 \\
\hline & $3 Q=$ & 6,5 & 0,6 \\
\hline & $4 Q=$ & 8,5 & 1,0 \\
\hline & $\| Q=$ & 1,1 & \\
\hline & $\mathrm{L} 1=$ & $1 \mathrm{Q}-1,5 \| \mathrm{Q}:$ & $-2,2$ \\
\hline & $\mathrm{L} 2=$ & $1 \mathrm{Q}-3,0 \| \mathrm{Q}:$ & $-3,8$ \\
\hline & $\mathrm{U} 1=$ & $3 \mathrm{Q}+1,5 \| \mathrm{Q}$ & 2,3 \\
\hline & $\mathrm{U} 2=$ & $3 \mathrm{Q}+3,0 \| \mathrm{Q}$ & 3,9 \\
\hline & Mediana: & 0,4 & \\
\hline
\end{tabular}

\begin{tabular}{|c|c|c|c|}
\hline MÉDIA: & 0,2 & & \\
\hline AMPLITUDE: & 2,0 & & \\
\hline N CLASSES: & 2 & 3 & \\
\hline FAIXA: & 1,0 & 0,7 & \\
\hline Consumo & ni & fi & fac \\
\hline$-1,0$ a $-0,3$ & 2 & 0,25 & 0,25 \\
\hline$-0,3$ a 0,4 & 2 & 0,25 & 0,50 \\
\hline 0,4 a 1,1 & 4 & 0,50 & 1,00 \\
\hline soma $=$ & 8 & & \\
\hline
\end{tabular}

onde: $\mathrm{ni}=\mathrm{n}^{\circ}$ de ocorrências em cada classe de consumo $f i=$ frequêtncia relativa do $n^{\circ}$ de ocorrência/classe fac $=$ freqüência acumulada do $n^{0}$ de ocorrências

$\begin{array}{lc}\text { onde: } & \\ 1 Q= & \left(1^{\circ} \text { quartil) }\right. \\ 2 \mathrm{Q}= & \left(2^{\circ} \text { quartil) }\right. \\ 3 \mathrm{Q}= & \left(3^{\circ} \text { quartil) }\right. \\ 4 \mathrm{Q}= & \left(4^{\circ} \text { quartil) }\right. \\ \| \mathrm{Q}= & \text { (intervalo interquartil) } \\ \mathrm{L} 1= & \text { grade interna inferior } \\ \mathrm{L} 2= & \text { grade externa inferior } \\ \mathrm{U} 1= & \text { grade interna superior } \\ \mathrm{U} 2= & \text { grade externa superior }\end{array}$

Nessa análise, não foram encontrados "outliers" nos consumos médios de VRPs com controle automático de saida 
ANÁLISE 5.1: ÁREAS DE VRP AUTOMÁTICA (até 12 econ./Lig.) BOX-PLOT COM CERCAS, DOS VALORES DE CONSUMO MÉDIO NAS ÁREAS DE VRP, PARA IDENTIFICAÇÃO DE OUTLIERS

\begin{tabular}{|c|c|c|c|c|}
\hline & VRP & ANTES (Xi) & APÓS (Yi) & $(X i-Y i)$ \\
\hline 1 & $\mathrm{C} 5$ & 16,5 & 17,5 & $-1,0$ \\
\hline 2 & C6 & 16,3 & 16,9 & $-0,5$ \\
\hline 3 & C7 & 178 & 17.8 & $-0,1$ \\
\hline 4 & $\mathrm{C} 1$ & 34,0 & 33,7 & 0,3 \\
\hline 5 & $\mathrm{C} 4$ & 26,7 & 26,4 & 0,3 \\
\hline 6 & C9 & 25,8 & 25,4 & 0,4 \\
\hline 7 & C3 & 29,9 & 29,5 & 0,4 \\
\hline 8 & C10 & 42,9 & 42,2 & 0,7 \\
\hline 9 & $\mathrm{C} 2$ & 23,3 & 22,5 & 0,8 \\
\hline 10 & C8 & 434 & 425 & 1.0 \\
\hline
\end{tabular}
(*) $\mathrm{C} 1$ a $\mathrm{C} 10=$ áreas com VRP Automática

\begin{tabular}{rrrr}
\multicolumn{5}{c}{} & \multicolumn{3}{c}{ Posição } \\
\hline Mediana: & $2 \mathrm{Q}=$ & 3,0 & $-0,1$ \\
& $3 \mathrm{Q}=$ & 5,5 & 0,3 \\
$\mathrm{4Q}=$ & 10,0 & 0,7 \\
& $\mathrm{IQ}=$ & 0,8 & 1,0 \\
$\mathrm{~L} 1=$ & $1 \mathrm{Q}-1,5 \| \mathrm{Q}:$ & $-1,3$ \\
& $\mathrm{~L} 2=$ & $1 \mathrm{Q}-3,0 \| \mathrm{Q}:$ & $-2,5$ \\
& $\mathrm{U} 1=$ & $3 \mathrm{Q}+1,5 \| \mathrm{Q}$ & 1,9 \\
& $\mathrm{U} 2=$ & $3 \mathrm{Q}+3,0 \| \mathrm{Q}$ & 3,1
\end{tabular}

MÉDIA:

AMPLITUDE:

No CLASSES:

FAIXA:

3
0,7

$\begin{array}{ccccc}\text { Classe } & \text { Consumo } & \text { ni } & \text { fi } & \text { fac } \\ 1 & -1,0 \text { a }-0,3 & 2 & 0,20 & 0,20 \\ 2 & -0,3 \text { a } 0,4 & 3 & 0,30 & 0,50 \\ 3 & 0,4 \text { a } 1,1 & 5 & 0,50 & 1,00 \\ & \text { soma }= & 10 & & \end{array}$

onde: $n i=n^{0}$ de ocorrências em cada classe de consumo $\mathrm{fi}=$ freqüência relativa do $n^{\circ}$ de ocorrência/classe fac $=$ freqüência acumulada do $n^{0}$ de ocorrências

$\begin{array}{lc}\text { onde: } & \\ 1 \mathrm{Q}= & \left(1^{\circ} \text { quartil) }\right. \\ 2 \mathrm{Q}= & \left(2^{\circ} \text { quartil) }\right. \\ 3 \mathrm{Q}= & \left(3^{\circ} \text { quartil }\right) \\ 4 \mathrm{Q}= & \left(4^{\circ} \text { quartil) }\right. \\ \| \mathrm{Q}= & \text { (intervalo interquartil) } \\ \mathrm{L} 1= & \text { grade interna inferior } \\ \mathrm{L} 2= & \text { grade externa inferior } \\ \mathrm{U} 1= & \text { grade interna superior } \\ \mathrm{U} 2= & \text { grade externa superior }\end{array}$

Nessa análise não foram identificados "outliers"

ANÁLISE 5.2: ÁREAS DE VRP AUTOMÁTICA (até 3 econ./Lig.)

BOX-PLOT COM CERCAS, DOS VALORES DE CONSUMO MÉDIO NAS ÁREAS DE VRP, PARA IDENTIFICAÇÃO DE OUTLIERS

\begin{tabular}{|c|c|c|c|c|}
\hline & VRP & ANTES (Xi) & APÓS (Yi) & $(X i-Y i)$ \\
\hline 1 & C5 & 16,2 & 17,2 & $-1,0$ \\
\hline 2 & C6 & 15,9 & 16,4 & $-0,5$ \\
\hline 3 & C4 & 22,1 & 22,3 & $-0,2$ \\
\hline 4 & C7 & 17,6 & 17,6 & 0,0 \\
\hline 5 & C9 & 22,2 & 22,1 & 0,2 \\
\hline 6 & $\mathrm{C} 1$ & 29,2 & 28,9 & 0,3 \\
\hline 7 & C3 & 22,9 & 22,3 & 0,6 \\
\hline 8 & $\mathrm{C} 2$ & 22,6 & 22,0 & 0,6 \\
\hline 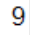 & C8 & 29,6 & 28,4 & 1,2 \\
\hline 10 & C10 & 36,3 & 34,9 & 1,4 \\
\hline
\end{tabular}

$\left.{ }^{*}\right)$ Xi $\mathrm{e} Y \mathrm{i}=$ valores de consumo médio em m³/mês/ligação (*) $\mathrm{C} 1$ a $\mathrm{C} 10=$ áreas com VRP Automática

\begin{tabular}{|c|c|c|c|}
\hline & \multicolumn{3}{|c|}{ Posição } \\
\hline & $1 \mathrm{Q}=$ & 3,0 & $-0,2$ \\
\hline Mediana & $2 \mathrm{Q}=$ & 5,5 & 0,2 \\
\hline & $3 Q=$ & 8,0 & 0,6 \\
\hline & $4 Q=$ & 10,5 & 1,4 \\
\hline & $\| \mathrm{Q}=$ & 0,8 & \\
\hline & $\mathrm{L} 1=$ & $1 \mathrm{Q}-1,5 \| \mathrm{Q}:$ & $-1,4$ \\
\hline & $\mathrm{L} 2=$ & $1 \mathrm{Q}-3,0 \| \mathrm{Q}:$ & $-2,6$ \\
\hline & $\mathrm{U} 1=$ & $3 \mathrm{Q}+1,5 \| \mathrm{Q}$ & 1,8 \\
\hline & $\mathrm{U} 2=$ & $3 \mathrm{Q}+3,0 \| \mathrm{Q}$ & 3 \\
\hline Mediana: & & & \\
\hline
\end{tabular}

$\begin{array}{lr}\text { MÉDIA: } & 0,2 \\ \text { AMPLITUDE: } & 2,4 \\ \text { No CLASSES: } & 3 \\ \text { FAIXA: } & 0,8\end{array}$

$\begin{array}{ccccc}\text { Classe } & \text { Consumo } & \text { ni } & \text { fi } & \text { fac } \\ 1 & -1,0 \text { a }-0,2 & 2 & 0,20 & 0,20 \\ 2 & -0,2 \text { a } 0,6 & 4 & 0,40 & 0,60 \\ 3 & 0,6 \text { a } 1,4 & 4 & 0,40 & 1,00\end{array}$

onde: $\mathrm{ni}=\mathrm{n}^{\circ}$ de ocorrências em cada classe de consumo $\mathrm{fi}=$ freqüência relativa do $\mathrm{n}^{0}$ de ocorrência/classe fac $=$ freqüência acumulada do $n^{0}$ de ocorrências

$\begin{array}{rc}\text { onde: } & \\ 1 \mathrm{Q}= & \left(1^{\circ} \text { quartil) }\right. \\ 2 \mathrm{Q}= & \left(2^{\circ} \text { quartil) }\right. \\ 3 \mathrm{Q}= & \left(3^{\circ} \text { quartil) }\right. \\ 4 \mathrm{Q}= & \left(4^{\circ} \text { quartil) }\right. \\ \| \mathrm{Q}= & \text { (intervalo interquartil) } \\ \mathrm{L} 1= & \text { grade interna inferior } \\ \mathrm{L} 2= & \text { grade externa inferior } \\ \mathrm{U} 1= & \text { grade interna superior } \\ \mathrm{U} 2= & \text { grade externa superior }\end{array}$

Nessa análise não foram identificados "outliers" 
ANÁLISE 5.3: ÁREAS DE VRP AUTOMÁTICA (1 econ./Lig.)

BOX-PLOT COM CERCAS, DOS VALORES DE CONSUMO MÉDIO NAS ÁREAS DE VRP, PARA IDENTIFICAÇÃO DE OUTLIERS

\begin{tabular}{|c|c|c|c|c|}
\hline & VRP & ANTES (Xi) & APÓS (Yi) & $(X i-Y i)$ \\
\hline 1 & $\mathrm{C} 5$ & 14,1 & 15,0 & $-0,8$ \\
\hline 2 & C6 & 14,1 & 14,6 & $-0,5$ \\
\hline 3 & $\mathrm{C} 4$ & 21,7 & 22,1 & $-0,4$ \\
\hline 4 & C7 & 16,8 & 16,8 & 0,0 \\
\hline 5 & C9 & 21,8 & 21,6 & 0,2 \\
\hline 6 & C1 & 28,9 & 287 & 0,3 \\
\hline 7 & $\mathrm{C} 2$ & 22,0 & 21,4 & 0,6 \\
\hline 8 & C3 & 22,7 & 22,0 & 0,6 \\
\hline 9 & $\mathrm{C} 8$ & 29,6 & 28,4 & 1,2 \\
\hline 10 & C10 & 36,3 & 34,9 & 1,4 \\
\hline
\end{tabular}

$\left.{ }^{*}\right) \mathrm{Xi}$ e $\mathrm{Yi}=$ valores de consumo médio $\mathrm{em} \mathrm{m}^{3} / \mathrm{mês} /$ ligação $\left.{ }^{* *}\right)$ C1 a C10 = áreas com VRP Automática

\begin{tabular}{|c|c|c|c|}
\hline & \multicolumn{3}{|c|}{ Posição } \\
\hline & $1 \mathrm{Q}=$ & 3,0 & $-0,4$ \\
\hline Mediana: & $2 \mathrm{Q}=$ & 5,5 & 0,2 \\
\hline & $3 Q=$ & 8,0 & 0,6 \\
\hline & $4 Q=$ & 10,5 & 1,4 \\
\hline & $\| Q=$ & 1,0 & \\
\hline & $\mathrm{L} 1=$ & $1 \mathrm{Q}-1,5 \| \mathrm{Q}:$ & $-1,9$ \\
\hline & $\mathrm{L} 2=$ & $1 \mathrm{Q}-3,0 \| \mathrm{Q}:$ & $-3,4$ \\
\hline & $\mathrm{U} 1=$ & $3 \mathrm{Q}+1,5 \| \mathrm{Q}$ & 2,1 \\
\hline & $\mathrm{U} 2=$ & $3 \mathrm{Q}+3,0 \| \mathrm{Q}$ & 3,6 \\
\hline
\end{tabular}

0,2

2,2

3

$0,7 \quad 0,8$

$\begin{array}{ccccc}\text { Classe } & \text { Consumo } & \text { ni } & \text { fi } & \text { fac } \\ 1 & -0,8 \text { a } 0,0 & 3 & 0,30 & 0,30 \\ 2 & 0,0 \text { a } 0,8 & 5 & 0,50 & 0,80 \\ 3 & 0,8 \text { a } 1,6 & 2 & 0,20 & 1,00\end{array}$

onde: $n i=n^{0}$ de ocorrências em cada classe de consumo $\mathrm{fi}_{\mathrm{i}}=$ freqüência relativa do $\mathrm{n}^{0}$ de ocorrência/classe fac $=$ freqüência acumulada do $n^{0}$ de ocorrências

onde:

$1 \mathrm{Q}=$

$2 \mathrm{Q}=$

$3 \mathrm{Q}=$

$4 \mathrm{Q}=$

$\| \mathrm{Q}=$

$\mathrm{L} 1=$

$\mathrm{L} 2=$

$\mathrm{U} 1=$

$\mathrm{U} 2=$ $\left(1^{\circ}\right.$ quartil)
$\left(2^{\circ}\right.$ quartil)
$\left(3^{\circ}\right.$ quartil)
$\left(4^{\circ}\right.$ quartil) (intervalo interquartil) grade interna inferior grade externa inferior grade interna superior grade externa superior

Nessa análise não foram identificados "outliers". 
ANÁLISE 6: ÁREAS TESTEMUNHA - VRP FIXA (1)

BOX-PLOT COM CERCAS, DOS VALORES DE CONSUMO MÉDIO NAS ÁREAS DE VRP, PARA IDENTIFICAÇÃO DE OUTLIERS

\begin{tabular}{|c|c|c|c|c|}
\hline & VRP & ANTES (Xi) & APÓS (Yi) & $(X i-Y i)$ \\
\hline 1 & \begin{tabular}{|l} 
F14 Test. \\
F14 Test
\end{tabular} & 48,5 & 50,2 & $-1,8$ \\
\hline 2 & F15 Test. & 13,0 & 14.1 & $-1,2$ \\
\hline 3 & F1 Test. & 159 & 15,8 & 0,1 \\
\hline 4 & F3 Test & 172 & 170 & 02 \\
\hline 5 & F17 Test. & 14,3 & 14,0 & 0,2 \\
\hline 6 & F9 Test. & 22,2 & 21,7 & 0,5 \\
\hline 7 & F8 Test. & 22,6 & 22,0 & 0,6 \\
\hline 8 & F2 Test. & 18,5 & 17,8 & 0,7 \\
\hline 9 & F11 Test. & 14,5 & 13,7 & 0,8 \\
\hline & F6 Test. & 15,4 & 14,3 & 1,1 \\
\hline & F7 Test. & 19.7 & 18.4 & 1,2 \\
\hline 2 & F4 Test. & 197 & 18.4 & 13 \\
\hline 3 & \begin{tabular}{|l} 
F16 Test. \\
.
\end{tabular} & 16,3 & 14.9 & 1,5 \\
\hline 4 & F10 Test. & 43,6 & 42,1 & 1,5 \\
\hline 5 & \begin{tabular}{|l} 
F13 Test. \\
Tesest
\end{tabular} & 54,2 & 52.6 & 16 \\
\hline 6 & F12 Test. & 22,6 & 21,0 & 1,6 \\
\hline 7 & F5 Test. & 47,1 & 43,6 & 3,5 \\
\hline
\end{tabular}

$\begin{array}{lr}\text { MÉDIA: } & 0,8 \\ \text { AMPLITUDE: } & 5,3 \\ \text { N }{ }^{\circ} \text { CLASSES: } & 4 \\ \text { FAIXA: } & 1,3\end{array}$

$\begin{array}{ccccc}\text { Classe } & \text { Consumo } & \text { ni } & \text { fi } & \text { fac } \\ 1 & -1,8 \text { a }-0,4 & 2 & 0,12 & 0,12 \\ 2 & -0,4 \text { a } 1,0 & 7 & 0,41 & 0,53 \\ 3 & 1,0 \text { a } 2,4 & 7 & 0,41 & 0,94 \\ 4 & 2,4 \text { a } 3,8 & 1 & 0,06 & 1,00\end{array}$

onde: $\mathrm{ni}=\mathrm{n}^{0}$ de ocorrências em cada classe de consumo $\mathrm{fi}=$ freqüência relativa do $n^{0}$ de ocorrência/classe fac $=$ frequêencia acumulada do $n^{\circ}$ de ocorrências

${ }^{(*)} \mathrm{Xi}$ e $\mathrm{Yi}=$ valores de consumo médio em $\mathrm{m}^{3} / \mathrm{mês} /$ ligação

(*z) F1 Test a F15 Test = áreas testemunha de VRP Fixa

\begin{tabular}{|c|c|c|c|}
\hline & \multicolumn{3}{|c|}{ Posição } \\
\hline & $1 \mathrm{Q}=$ & 4,8 & 0,2 \\
\hline Mediana: & $2 \mathrm{Q}=$ & 9,0 & 0,8 \\
\hline & $3 Q=$ & 13,3 & 1,5 \\
\hline & $4 Q=$ & 17,5 & 3,5 \\
\hline & $\| \mathrm{Q}=$ & 1,3 & \\
\hline & $\mathrm{L} 1=$ & $1 \mathrm{Q}-1,5 \| \mathrm{Q}:$ & $-1,8$ \\
\hline & $\mathrm{L} 2=$ & $1 \mathrm{Q}-3,0 \| \mathrm{Q}:$ & $-3,7$ \\
\hline & $\mathrm{U} 1=$ & $3 Q+1,5 \| Q$ & 3,5 \\
\hline & $\mathrm{U} 2=$ & $3 Q+3,0 \| Q$ & 5,4 \\
\hline
\end{tabular}

$\begin{array}{cc}\text { onde: } & \\ 1 \mathrm{Q}= & \left(1^{\circ} \text { quartil) }\right. \\ 2 \mathrm{Q}= & \left(2^{\circ} \text { quartil) }\right. \\ 3 \mathrm{Q}= & \left(3^{\circ} \text { quartil }\right) \\ 4 \mathrm{Q}= & \left(4^{\circ} \text { quartil }\right) \\ \mathrm{IQ}= & \text { (intervalo interquartil) } \\ \mathrm{L} 1= & \text { grade interna inferior } \\ \mathrm{L} 2= & \text { grade externa inferior } \\ \mathrm{U} 1= & \text { grade interna superior } \\ \mathrm{U} 2= & \text { grade externa superior }\end{array}$

Como os consumos médios das áreas Testemunhas F14 e F5 cairam nos limites das cercas internas do "box-plot", foram classificados como "outliers" e, portanto, não serão utilizados nas análises. 
ANÁLISE 6: ÁREAS TESTEMUNHA - VRP FIXA (2)

BOX-PLOT COM CERCAS, DOS VALORES DE CONSUMO MÉDIO NAS ÁREAS DE VRP, PARA IDENTIFICAÇÃO DE OUTLIERS

\begin{tabular}{|c|c|c|c|}
\hline VRP & ANTES (Xi) & APÓS (Yi) & $(X i-Y i)$ \\
\hline 1 F15 Test. & 13,0 & 14,1 & $-1,2$ \\
\hline$2 \longdiv { F 1 \text { Test. } }$ & 15,9 & 15,8 & 0,1 \\
\hline 3 F3 Test. & 17,2 & 17,0 & 0,2 \\
\hline 4 F17 Test. & 14,3 & 14,0 & 0,2 \\
\hline 5 F9 Test. & 22,2 & 21,7 & 0,5 \\
\hline 6 F8 Test. & 22,6 & 22,0 & 0,6 \\
\hline 7 F2 Test. & 18,5 & 17,8 & 0,7 \\
\hline 8 F11 Test. & 14,5 & 13,7 & 0,8 \\
\hline 9 F6 Test. & 15,4 & 14,3 & 1,1 \\
\hline F7 Test. & 19,7 & 18,4 & 1,2 \\
\hline F4 Test. & 19.7 & 18.4 & 13 \\
\hline 2 F16 Test. & 16,3 & 14,9 & 1,5 \\
\hline 3 F10 Test. & 43,6 & 42,1 & 1,5 \\
\hline F13 Test. & 54,2 & 52,6 & 1,6 \\
\hline F12 Test. & 22,6 & 21,0 & 1,6 \\
\hline
\end{tabular}

$\left.{ }^{*}\right) \mathrm{Xi}$ e $\mathrm{Yi}=$ valores de consumo médio em $\mathrm{m}^{3} / \mathrm{mês} /$ ligação ${ }^{* *}$ F1 Test a F15 Test = áreas testemunha de VRP Fixa

\begin{tabular}{|c|c|c|c|}
\hline & \multicolumn{3}{|c|}{ Posição } \\
\hline & $1 \mathrm{Q}=$ & 4,3 & 0,2 \\
\hline Mediana: & $2 \mathrm{Q}=$ & 8,0 & 0,8 \\
\hline & $3 \mathrm{Q}=$ & 11,8 & 1,5 \\
\hline & $4 Q=$ & 15,5 & 1,6 \\
\hline & $\| \mathrm{Q}=$ & 1,3 & \\
\hline & $\mathrm{L} 1=$ & $1 \mathrm{Q}-1,5 \| \mathrm{Q}:$ & $-1,8$ \\
\hline & $\mathrm{L} 2=$ & $1 \mathrm{Q}-3,0 \| \mathrm{Q}:$ & $-3,7$ \\
\hline & $\mathrm{U} 1=$ & $3 \mathrm{Q}+1,5 \| \mathrm{Q}$ & 3,5 \\
\hline & $\mathrm{U} 2=$ & $3 \mathrm{Q}+3,0 \| \mathrm{Q}$ & 5,4 \\
\hline
\end{tabular}

Não foram observados "outliers" nessa série.

\begin{tabular}{|c|c|c|c|}
\hline MÉDIA: & & & \\
\hline AMPLITUDE: & & & \\
\hline $\mathrm{N}^{0}$ CLASSES: & & & \\
\hline FAIXA: & & & \\
\hline Consumo & ni & fi & fac \\
\hline$-1,3 a-0,3$ & 1 & 0,07 & 0,07 \\
\hline$-0,3$ a 0,7 & 5 & 0,33 & 0,40 \\
\hline 0,7 a 1,7 & 9 & 0,60 & 1,00 \\
\hline soma $=$ & 15 & & \\
\hline
\end{tabular}

onde: $n i=n^{0}$ de ocorrências em cada classe de consumo $\mathrm{fi}=$ freqüência relativa do $\mathrm{n}^{0}$ de ocorrência/classe fac $=$ frequeência acumulada do $n^{0}$ de ocorrências

$\begin{array}{lc}\text { onde: } & \\ 1 \mathrm{Q}= & \left(1^{\circ} \text { quartil }\right) \\ 2 \mathrm{Q}= & \left(2^{\circ} \text { quartil }\right) \\ 3 \mathrm{Q}= & \left(3^{\circ} \text { quartil }\right) \\ 4 \mathrm{Q}= & \left(4^{\circ} \text { quartil) }\right. \\ \| \mathrm{Q}= & \text { (intervalo interquartil) } \\ \mathrm{L} 1= & \text { grade interna inferior } \\ \mathrm{L} 2= & \text { grade externa inferior } \\ \mathrm{U} 1= & \text { grade interna superior } \\ \mathrm{U} 2= & \text { grade externa superior }\end{array}$

onde: (intervalo interquartil) grade interna inferior grade interna superior grade externa superior 
ANÁLISE 6.1: ÁREAS TESTEMUNHA - VRP FIXA (até 12 econ./Lig.)

BOX-PLOT COM CERCAS, DOS VALORES DE CONSUMO MÉDIO NAS ÁREAS DE VRP, PARA IDENTIFICAÇÃO DE OUTLIERS

\begin{tabular}{|c|c|c|c|c|}
\hline & AREA & ANTES (Xi) & APÓS (Yi) & $(X i-Y i)$ \\
\hline 1 & F14 Test. & 48,5 & 50,2 & $-1,8$ \\
\hline 2 & F15 Test. & 13,0 & 14,1 & $-1,2$ \\
\hline 3 & F1 Test. & 15,9 & 15,8 & 0,1 \\
\hline 4 & F3 Test. & 17,2 & 17,0 & 0,2 \\
\hline 5 & F17 Test. & 14,3 & 14,0 & 0,2 \\
\hline 6 & F9 Test. & 22,2 & 21,7 & 0,5 \\
\hline 7 & F8 Test. & 22,2 & 21,6 & 0,5 \\
\hline 8 & F2 Test. & 18,5 & 17,8 & 0,7 \\
\hline 9 & F11 Test. & 14,5 & 13,7 & 0,8 \\
\hline 10 & F10 Test. & 33,1 & 32,2 & 0,9 \\
\hline 11 & F6 Test. & 15,4 & 14,3 & 1,1 \\
\hline 12 & F7 Test. & 19,7 & 18,4 & 1,2 \\
\hline 13 & F4 Test. & 19,7 & 18,4 & 1,3 \\
\hline 14 & F16 Test. & 16,3 & 14,9 & 1,5 \\
\hline 15 & F13 Test. & 54,2 & 52,6 & 1,6 \\
\hline 16 & F12 Test. & 22,5 & 21.0 & 1.6 \\
\hline 17 & F5 Test. & 22,8 & 20,5 & 2,2 \\
\hline
\end{tabular}

$\left.{ }^{*}\right)$ Xi e Yi = valores de consumo médio em $\mathrm{m}^{3} / \mathrm{mês} /$ ligação

(*) F1 Test a F15 Test $=$ áreas testemunha de VRP Fixa

\begin{tabular}{rrrr}
\multicolumn{5}{c}{} & \multicolumn{3}{c}{ Posição } \\
\hline Mediana: & $2 \mathrm{Q}=$ & 4,8 & 0,2 \\
& $3 \mathrm{Q}=$ & 13,0 & 0,8 \\
& $\mathrm{4Q}=$ & 17,5 & 1,3 \\
& $\mathrm{IQ}=$ & 1,1 & 2,2 \\
$\mathrm{~L} 1=$ & $1 \mathrm{Q}-1,5 \| \mathrm{Q}:$ & $-1,5$ \\
& $\mathrm{~L} 2=$ & $1 \mathrm{Q}-3,0 \| \mathrm{Q}:$ & $-3,1$ \\
& $\mathrm{U} 1=$ & $3 \mathrm{Q}+1,5 \| \mathrm{Q}$ & 3,0 \\
& $\mathrm{U} 2=$ & $3 \mathrm{Q}+3,0 \| \mathrm{Q}$ & 4,6 \\
Mediana: & & &
\end{tabular}

$\begin{array}{lr}\text { MÉDIA: } & 0,7 \\ \text { AMPLITUDE: } & 4,0 \\ \text { N } & 4 \\ \text { FAIXA: } & 1,0\end{array}$

$\begin{array}{ccccc}\text { Classe } & \text { Consumo } & \text { ni } & \text { fi } & \text { fac } \\ 1 & -1,8 \mathrm{a}-0,8 & 2 & 0,12 & 0,12 \\ 2 & -0,8 \mathrm{a} 0,2 & 1 & 0,06 & 0,18 \\ 3 & 0,2 \mathrm{a} 1,2 & 8 & 0,47 & 0,65 \\ 4 & 1,2 \mathrm{a} 2,2 & 6 & 0,35 & 1,00\end{array}$

onde: $\mathrm{ni}=\mathrm{n}^{0}$ de ocorrências em cada classe de consumo $\mathrm{fi}=$ freqüência relativa do $\mathrm{n}^{0}$ de ocorrência/classe fac $=$ frequêtencia acumulada do $n^{0}$ de ocorrências

A análise identificou a área testemunha F14 Test como "outlier"; portanto os dados relativos a essa área não serão utilizados nas análises em referência.

$\begin{array}{cc}\text { onde: } & \\ 1 \mathrm{Q}= & \left(1^{\circ} \text { quartil) }\right. \\ 2 \mathrm{Q}= & \left(2^{\circ} \text { quartil }\right) \\ 3 \mathrm{Q}= & \left(3^{\circ} \text { quartil) }\right. \\ 4 \mathrm{Q}= & \left(4^{\circ} \text { quartil) }\right. \\ \mathrm{IQ}= & \text { (intervalo interquartil) } \\ \mathrm{L} 1= & \text { grade interna inferior } \\ \mathrm{L} 2= & \text { grade externa inferior } \\ \mathrm{U} 1= & \text { grade interna superior } \\ \mathrm{U} 2= & \text { grade externa superior }\end{array}$

onde:

$3 \mathrm{Q}=$

$4 \mathrm{Q}=$

$L 1=$

$\mathrm{L} 2=$

$\mathrm{U} 2=$ 
ANÁLISE 6.2: ÁREAS TESTEMUNHA - VRP FIXA (até 3 econ./Lig.)

BOX-PLOT COM CERCAS, DOS VALORES DE CONSUMO MÉDIO NAS ÁREAS DE VRP, PARA IDENTIFICAÇÃO DE OUTLIERS

\begin{tabular}{|c|c|c|c|c|}
\hline & AREA & ANTES (Xi) & APÓS (Yi) & $(X i-Y i)$ \\
\hline & F14 Test. & 20,9 & 22,1 & $-1,2$ \\
\hline & F15 Test. & 13,0 & 14,1 & $-1,1$ \\
\hline & F13 Test. & 21,0 & 21,5 & $-0,5$ \\
\hline & F1 Test. & 15,5 & 15,4 & 0,1 \\
\hline & F17 Test. & 14,2 & 14,0 & 0,2 \\
\hline & F3 Test. & 17.1 & 16.8 & 0,3 \\
\hline & F9 Test. & 22,2 & 21,7 & 0,5 \\
\hline & F8 Test. & 21,8 & 21,2 & 0,5 \\
\hline & F2 Test. & 18,1 & 17,4 & 0,7 \\
\hline 0 & F11 Test. & 14,5 & 13,7 & 0,8 \\
\hline 1 & F10 Test. & 31,4 & 30,6 & 0,8 \\
\hline & F6 Test. & 15,4 & 14,3 & 1,1 \\
\hline & F7 Test. & 19,5 & 18,2 & 1,2 \\
\hline & F4 Test. & 18,9 & 17.6 & 14 \\
\hline 5 & F16 Test & 16.3 & 149 & 15 \\
\hline & F12 Test. & 20,2 & 18,7 & 1,5 \\
\hline 7 & F5 Test. & 21,0 & 18,8 & 2,2 \\
\hline
\end{tabular}

${ }^{(*)} \mathrm{Xi}$ e $\mathrm{Yi}=$ valores de consumo médio em $\mathrm{m}^{3} / \mathrm{mês} /$ ligação

(*z) F1 Test a F15 Test $=$ áreas testemunha de VRP Fixa

\begin{tabular}{|c|c|c|c|}
\hline & \multicolumn{3}{|c|}{ Posição } \\
\hline & $1 \mathrm{Q}=$ & 4,8 & 0,2 \\
\hline Mediana & $2 \mathrm{Q}=$ & 9,0 & 0,7 \\
\hline & $3 Q=$ & 13,3 & 1,2 \\
\hline & $4 \mathrm{Q}=$ & 17,5 & 2,2 \\
\hline & $\| \mathrm{Q}=$ & 1,0 & \\
\hline & $\mathrm{L} 1=$ & $1 \mathrm{Q}-1,5 \| \mathrm{Q}:$ & $-1,3$ \\
\hline & $\mathrm{L} 2=$ & $1 \mathrm{Q}-3,0 \| \mathrm{Q}:$ & $-2,8$ \\
\hline & $\mathrm{U} 1=$ & $3 \mathrm{Q}+1,5 \| \mathrm{Q}$ & 2,7 \\
\hline & $\mathrm{U} 2=$ & $3 \mathrm{Q}+3,0 \| \mathrm{Q}$ & 4,2 \\
\hline
\end{tabular}

Mediana: 0,7

Nessa análise não foram identificados "outliers".

$\begin{array}{lr}\text { MÉDIA: } & 0,6 \\ \text { AMPLITUDE: } & 3,4 \\ \text { NNo CLASSES: } & 4 \\ \text { FAIXA: } & 0,9\end{array}$

$\begin{array}{ccccc}\text { Classe } & \text { Consumo } & \text { ni } & \text { fi } & \text { fac } \\ 1 & -1,2 \text { a }-0,3 & 3 & 0,18 & 0,18 \\ 2 & -0,3 \text { a } 0,6 & 5 & 0,29 & 0,47 \\ 3 & 0,6 \text { a } 1,5 & 6 & 0,35 & 0,82 \\ 4 & 1,5 \text { a } 2,4 & 3 & 0,18 & 1,00\end{array}$

onde: $\mathrm{ni}=\mathrm{n}^{0}$ de ocorrências em cada classe de consumo $\mathrm{fi}=$ freqüência relativa do $\mathrm{n}^{0}$ de ocorrência/classe fac $=$ freqüência acumulada do $n^{0}$ de ocorrências 
ANÁLISE 6.3: ÁREAS TESTEMUNHA - VRP FIXA (1 econ./Lig.)

BOX-PLOT COM CERCAS, DOS VALORES DE CONSUMO MÉDIO NAS ÁREAS DE VRP, PARA IDENTIFICAÇÃO DE OUTLIERS

\begin{tabular}{|c|c|c|c|c|}
\hline & AREA & ANTES $(\mathrm{Xi})$ & APÓS (Yi) & $(X i-Y i)$ \\
\hline 1 & F15 Test. & 12,8 & 13,8 & $-1,0$ \\
\hline 2 & F14 Test. & 21,9 & 22,5 & $-0,6$ \\
\hline 3 & F1 Test. & 14,1 & 14,1 & 0,1 \\
\hline 41 & F13 Test. & 21,2 & 21,1 & 0,1 \\
\hline 5 & F17 Test. & 13,6 & 13,4 & 0,2 \\
\hline 6 & F3 Test. & 16,0 & 15,7 & 0,2 \\
\hline 7 & F8 Test. & 21.4 & 21,0 & 0,4 \\
\hline 8 & F9 Test. & 22,2 & 21,7 & 0,5 \\
\hline 9 & F2 Test. & 16,7 & 16,1 & 0,6 \\
\hline 0 & F10 Test. & 31,5 & 30,7 & 0,8 \\
\hline 1 & F11 Test. & 14,0 & 13,0 & 1,0 \\
\hline 2 & F6 Test. & 14,4 & 13,3 & 1,1 \\
\hline 3 & F12 Test. & 18,3 & 17,1 & 1,2 \\
\hline 4 & F7 Test. & 19,0 & 17,7 & 1,2 \\
\hline 5 & F4 Test. & 17,8 & 16,2 & 1,6 \\
\hline 16 & F16 Test. & 15,9 & 14,2 & 1,7 \\
\hline 7 & F5 T & 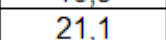 & 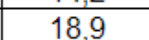 & 2.2 \\
\hline
\end{tabular}

${ }^{(*)} \mathrm{Xi}$ e Yi = valores de consumo médio em $\mathrm{m}^{3} / \mathrm{mês} /$ ligação $\left.{ }^{(* *}\right)$ F1 Test a F15 Test = áreas testemunha de VRP Fixa

\begin{tabular}{rrrr}
\multicolumn{1}{c}{} & \multicolumn{3}{c}{ Posição } \\
\hline Mediana: & $2 \mathrm{Q}=$ & 4,8 & 0,2 \\
& $3 \mathrm{Q}=$ & 9,0 & 0,6 \\
& $\mathrm{4Q}=$ & 13,3 & 1,2 \\
& $\mathrm{IQ}=$ & 1,5 & 2,2 \\
$\mathrm{~L} 1=$ & $1 \mathrm{Q}-1,5 \| \mathrm{Q}:$ & $-1,3$ \\
& $\mathrm{~L} 2=$ & $1 \mathrm{Q}-3,0 \| \mathrm{Q}:$ & $-2,8$ \\
& $\mathrm{U} 1=$ & $3 \mathrm{Q}+1,5 \| \mathrm{Q}$ & 2,7 \\
& $\mathrm{U} 2=$ & $3 \mathrm{Q}+3,0 \| \mathrm{Q}$ & 4,2 \\
Mediana: & & &
\end{tabular}

$\begin{array}{lr}\text { MÉDIA: } & 0,7 \\ \text { AMPLITUDE: } & 3,2 \\ \text { No }{ }^{\circ} \text { CLASSES: } & 4 \\ \text { FAIXA: } & 0,8\end{array}$

$\begin{array}{ccccc}\text { Classe } & \text { Consumo } & \text { ni } & \text { fi } & \text { fac } \\ 1 & -1,0 \text { a }-0,2 & 2 & 0,12 & 0,12 \\ 2 & -0,2 \text { a } 0,6 & 6 & 0,35 & 0,47 \\ 3 & 0,6 \text { a } 1,4 & 6 & 0,35 & 0,82 \\ 4 & 1,4 \text { a } 2,2 & 3 & 0,18 & 1,00 \\ & \text { soma }= & 17 & & \end{array}$

onde: $\mathrm{ni}=\mathrm{n}^{0}$ de ocorrências em cada classe de consumo $\mathrm{fi}=$ freqüência relativa do $n^{0}$ de ocorrência/classe fac $=$ freqüência acumulada do $n^{0}$ de ocorrências

Nessa análise não foram identificados "outliers".

$\begin{array}{cc}\text { onde: } & \\ 1 \mathrm{Q}= & \left(1^{\circ} \text { quartil) }\right. \\ 2 \mathrm{Q}= & \left(2^{\circ} \text { quartil) }\right. \\ 3 \mathrm{Q}= & \left(3^{\circ} \text { quartil }\right) \\ 4 \mathrm{Q}= & \left(4^{\circ} \text { quartil) }\right. \\ \| \mathrm{Q}= & \text { (intervalo interquartil) } \\ \mathrm{L} 1= & \text { grade interna inferior } \\ \mathrm{L} 2= & \text { grade externa inferior } \\ \mathrm{U} 1= & \text { grade interna superior } \\ \mathrm{U} 2= & \text { grade externa superior }\end{array}$

onde: 
ANÁLISE 7: ÁREAS TESTEMUNHA - VRP AUTOMÁTICA (1)

BOX-PLOT COM CERCAS, DOS VALORES DE CONSUMO MÉDIO NAS ÁREAS DE VRP, PARA IDENTIFICAÇÃO DE OUTLIERS

\begin{tabular}{|c|c|c|c|}
\hline VRP & ANTES (Xi) & APÓS (Yi) & $(X i-Y i)$ \\
\hline C3 Test. & 52,8 & 57,9 & $-5,2$ \\
\hline C10 Test. & 58,8 & 63,4 & $-4,6$ \\
\hline C6 Test. & 16,6 & 17,6 & $-1,0$ \\
\hline C5 Test. & 16,8 & 17,6 & $-0,8$ \\
\hline C1 Test. & 36,1 & 36,8 & $-0,7$ \\
\hline C2 Test. & 88,0 & 88,1 & $-0,2$ \\
\hline C7 Test. & 19,3 & 19,3 & $-0,1$ \\
\hline C9 Test. & 38,9 & 38,6 & 0,3 \\
\hline C4 Test. & 30,0 & 29,0 & 1,0 \\
\hline C8 Test. & 83,5 & 82,0 & 1,5 \\
\hline
\end{tabular}

Posição

\begin{tabular}{rrrr} 
& $1 \mathrm{Q}=$ & 3,0 & $-1,0$ \\
\hline Mediana: & $2 \mathrm{Q}=$ & 5,5 & $-0,4$ \\
\hline & $3 \mathrm{Q}=$ & 8,0 & 0,3 \\
$\mathrm{4Q}$ & $=$ & 10,5 & 1,5 \\
$\mathrm{IQ}=$ & 1,3 & \\
$\mathrm{~L} 1=$ & $1 \mathrm{Q}-1,5 \| \mathrm{Q}:$ & $-3,0$ \\
& $\mathrm{~L} 2=$ & $1 \mathrm{Q}-3,0 \| \mathrm{Q}:$ & $-4,9$ \\
& $\mathrm{U} 1=$ & $3 \mathrm{Q}+1,5 \| \mathrm{Q}$ & 2,3 \\
& $\mathrm{U} 2=$ & $3 \mathrm{Q}+3,0 \| \mathrm{Q}$ & 4,2 \\
Mediana: & & &
\end{tabular}
$-0,4$

$\begin{array}{lr}\text { MÉDIA: } & -1,0 \\ \text { AMPLITUDE: } & 6,7 \\ \text { N }{ }^{\circ} \text { CLASSES: } & 3 \\ \text { FAIXA: } & 2,1\end{array}$

Classe

Consumo
$-5,2$ a $-2,9$
$-2,9$ a $-0,6$
$-0,6$ a 1,7

ni
2
3
5

ni
2
3
5
10

fi

0,20

$0,30 \quad 0,50$

$0,50 \quad 1,00$

onde: $n i=n^{0}$ de ocorrências em cada classe de consumo $\mathrm{fi}=$ frequeência relativa do $n^{0}$ de ocorrência/classe fac $=$ freqüência acumulada do $n^{0}$ de ocorrências

$\begin{array}{rc}\text { onde: } & \\ 1 \mathrm{Q}= & \left(1^{\circ} \text { quartil }\right) \\ 2 \mathrm{Q}= & \left(2^{\circ} \text { quartil) }\right. \\ 3 \mathrm{Q}= & \left(3^{\circ} \text { quartil) }\right. \\ 4 \mathrm{Q}= & \left(4^{\circ} \text { quartil) }\right. \\ \mathrm{IQ}= & \text { (intervalo interquartil) } \\ \mathrm{L} 1= & \text { grade interna inferior } \\ \mathrm{L} 2= & \text { grade externa inferior } \\ \mathrm{U} 1= & \text { grade interna superior } \\ \mathrm{U} 2= & \text { grade externa superior }\end{array}$

Dessa análise constata-se que os consumos médios das áreas Testemunhas C3 e C10 foram classificados como "outliers" (fora dos limites da cerca interna inferior do "box-plot"), devendo ser descartados nas análises.

ANÁLISE 7: ÁREAS TESTEMUNHA - VRP AUTOMÁTICA (2)

BOX-PLOT COM CERCAS, DOS VALORES DE CONSUMO MÉDIO NAS ÁREAS DE VRP, PARA IDENTIFICAÇÃO DE OUTLIERS

\begin{tabular}{|c|c|c|c|}
\hline VRP & ANTES (Xi) & APÓS (Yi) & $(X i-Y i)$ \\
\hline C6 Test. & 16,6 & 17,6 & $-1,0$ \\
\hline C5 Test. & 16,8 & 17,6 & $-0,8$ \\
\hline C1 Test. & 36,1 & 36,8 & $-0,7$ \\
\hline C2 Test. & 88,0 & 88,1 & $-0,2$ \\
\hline C7 Test. & 19,3 & 19,3 & $-0,1$ \\
\hline C9 Test. & 38,9 & 38,6 & 0,3 \\
\hline C4 Test. & 30,0 & 29,0 & 1,0 \\
\hline C8 Test. & 83,5 & 82,0 & 1,5 \\
\hline
\end{tabular}

Classe
1
2
3

$\begin{array}{lr}\text { MÉDIA: } & 0,0 \\ \text { AMPLITUDE: } & 2,5 \\ \text { N } & 3 \\ \text { FAIXA: } & 0,9\end{array}$

(*t) C1 Test a C10 Test = áreas testemunha de VRP Automática

$\begin{array}{cccc}\text { Consumo } & \text { ni } & \text { fi } & \text { fac } \\ -1,0 \text { a }-0,1 & 4 & 0,50 & 0,50 \\ -0,1 \text { a } 0,8 & 2 & 0,25 & 0,75 \\ 0,8 \text { a } 1,7 & 2 & 0,25 & 1,00\end{array}$

nde: $\mathrm{ni}=\mathrm{n}^{0}$ de ocorrências em cada classe de consumo $\mathrm{fi}=$ freqüência relativa do $\mathrm{n}^{0}$ de ocorrência/classe fac $=$ frequêencia acumulada do $n^{0}$ de ocorrências

\begin{tabular}{|c|c|c|c|}
\hline & \multicolumn{3}{|c|}{ Posição } \\
\hline & $1 \mathrm{Q}=$ & 2,5 & $-0,8$ \\
\hline Mediana: & $2 \mathrm{Q}=$ & 4,5 & $-0,1$ \\
\hline & $3 Q=$ & 6,5 & 0,3 \\
\hline & $4 Q=$ & 8,5 & 1,5 \\
\hline & $\| \mathrm{Q}=$ & 1,1 & \\
\hline & $\mathrm{L} 1=$ & $1 \mathrm{Q}-1,5 \| \mathrm{Q}:$ & $-2,5$ \\
\hline & $\mathrm{L} 2=$ & $1 \mathrm{Q}-3,0 \| \mathrm{Q}:$ & $-4,1$ \\
\hline & $\mathrm{U} 1=$ & $3 \mathrm{Q}+1,5 \| \mathrm{Q}$ & 2,0 \\
\hline & $\mathrm{U} 2=$ & $3 \mathrm{Q}+3,0 \| \mathrm{Q}$ & 3,6 \\
\hline Mediana: & & & \\
\hline
\end{tabular}

$\begin{array}{cc}\text { onde: } & \\ 1 \mathrm{Q}= & \left(1^{\circ} \text { quartil) }\right. \\ 2 \mathrm{Q}= & \left(2^{\circ} \text { quartil }\right) \\ 3 \mathrm{Q}= & \left(3^{\circ} \text { quartil) }\right. \\ 4 \mathrm{Q}= & \left(4^{\circ} \text { quartil) }\right. \\ \mathrm{IQ}= & \text { (intervalo interquartil) } \\ \mathrm{L} 1= & \text { grade interna inferior } \\ \mathrm{L} 2= & \text { grade externa inferior } \\ \mathrm{U} 1= & \text { grade interna superior } \\ \mathrm{U} 2= & \text { grade externa superior }\end{array}$

Nessa análise, não foram identificados "outliers" entre os consumos médios das áreas testemunha 
ANÁLISE 7.1: ÁREAS TESTEMUNHA - VRP AUTO (até 12 econ./Lig.)

BOX-PLOT COM CERCAS, DOS VALORES DE CONSUMO MÉDIO NAS ÁREAS DE VRP, PARA IDENTIFICAÇÃO

\begin{tabular}{r|c|c|c|c|}
\cline { 2 - 5 } & AREA & ANTES $(\mathrm{Xi})$ & APÓS $(\mathrm{Yi})$ & $(\mathrm{Xi}-\mathrm{Yi})$ \\
\cline { 2 - 5 } 1 & C6 Test. & 16,6 & 17,6 & $-1,0$ \\
\cline { 2 - 5 } 2 & C5 Test. & 15,3 & 16,0 & $-0,7$ \\
\cline { 2 - 5 } 3 & C10 Test. & 31,7 & 32,1 & $-0,5$ \\
\cline { 2 - 5 } 4 & C1 Test. & 29,4 & 29,8 & $-0,5$ \\
\cline { 2 - 5 } 5 & C9 Test. & 25,7 & 26,1 & $-0,3$ \\
\hline & C7 Test. & 17,6 & 17,9 & $-0,2$ \\
\cline { 2 - 5 } 7 & C3 Test. & 37,7 & 37,5 & 0,2 \\
\cline { 2 - 5 } 8 & C8 Test. & 32,5 & 31,0 & 1,5 \\
\cline { 2 - 5 } & C4 Test. & 25,5 & 23,8 & 1,7 \\
\cline { 2 - 5 } 10 & C2 Test. & 45,7 & 43,4 & 2,3 \\
\cline { 2 - 5 } & & &
\end{tabular}

(*) Xi e Yi = valores de consumo médio em m³/mês/ligação

(**) C1 Test a C10 Test $=$ áreas testemunha de VRP Automática

\begin{tabular}{|c|c|c|c|}
\hline & \multicolumn{3}{|c|}{ Posição } \\
\hline & $1 \mathrm{Q}=$ & 3,0 & $-0,5$ \\
\hline Mediana: & $2 \mathrm{Q}=$ & 5,5 & $-0,3$ \\
\hline & $3 Q=$ & 8,0 & 1,5 \\
\hline & $4 Q=$ & 10,5 & 2 , \\
\hline & $\| \mathrm{Q}=$ & 2,0 & \\
\hline & $\mathrm{L} 1=$ & $1 \mathrm{Q}-1,5 \| \mathrm{Q}:$ & -3 , \\
\hline & $\mathrm{L} 2=$ & $1 \mathrm{Q}-3,0 \| \mathrm{Q}:$ & -6 \\
\hline & $\mathrm{U} 1=$ & $3 \mathrm{Q}+1,5 \| \mathrm{Q}$ & 4 \\
\hline & $\mathrm{U} 2=$ & $3 \mathrm{Q}+3,0 \| \mathrm{Q}$ & 7 , \\
\hline Mediana: & & & \\
\hline
\end{tabular}

$\begin{array}{lr}\text { MÉDIA: } & 0,2 \\ \text { AMPLITUDE: } & 3,4 \\ \text { N } & 3 \\ \text { FAIXA: } & 1,1\end{array}$

$\begin{array}{ccccc}\text { Classe } & \text { Consumo } & \text { ni } & \text { fi } & \text { fac } \\ 1 & -1,0 \text { a } 0,2 & 6 & 0,60 & 0,60 \\ 2 & 0,2 \text { a } 1,4 & 1 & 0,10 & 0,70 \\ 3 & 1,4 \text { a } 2,6 & 3 & 0,30 & 1,00\end{array}$

onde: $\mathrm{ni}=\mathrm{n}^{0}$ de ocorrências em cada classe de consumo

$\mathrm{fi}=$ freqüência relativa do $\mathrm{n}^{0}$ de ocorrência/classe fac $=$ freque ência acumulada do $n^{0}$ de ocorrências

$\begin{array}{lc}\text { onde: } & \\ 1 \mathrm{Q}= & \left(1^{\circ} \text { quartil }\right) \\ 2 \mathrm{Q}= & \left(2^{\circ} \text { quartil }\right) \\ 3 \mathrm{Q}= & \left(3^{\circ} \text { quartil }\right) \\ 4 \mathrm{Q}= & \left(4^{\circ} \text { quartil) }\right. \\ \mathrm{IQ}= & \text { (intervalo interquartil) } \\ \mathrm{L} 1= & \text { grade interna inferior } \\ \mathrm{L} 2= & \text { grade externa inferior } \\ \mathrm{U} 1= & \text { grade interna superior } \\ \mathrm{U} 2= & \text { grade externa superior }\end{array}$

Não foram identificados "outliers" nessa análise.

ANÁLISE 7.2: ÁREAS TESTEMUNHA - VRP AUTO (até 3 econ./Lig.)

BOX-PLOT COM CERCAS, DOS VALORES DE CONSUMO MÉDIO NAS ÁREAS DE VRP, PARA IDENTIFICAÇÃO

\begin{tabular}{|c|c|c|c|c|}
\cline { 2 - 5 } & AREA & ANTES $(\mathrm{Xi})$ & APÓS $(\mathrm{Yi})$ & $(\mathrm{Xi}-\mathrm{Yi})$ \\
\cline { 2 - 5 } 1 & C6 Test. & 16,2 & 17,2 & $-1,0$ \\
\cline { 2 - 5 } 2 & C5 Test. & 15,0 & 15,8 & $-0,7$ \\
\cline { 2 - 5 } 3 & C10 Test. & 23,1 & 23,7 & $-0,6$ \\
\cline { 2 - 5 } 4 & C1 Test. & 25,2 & 25,7 & $-0,5$ \\
\cline { 2 - 5 } 5 & C3 Test. & 36,4 & 36,8 & $-0,4$ \\
\cline { 2 - 5 } 6 & C7 Test. & 17,3 & 17,5 & $-0,2$ \\
\cline { 2 - 5 } 7 & C9 Test. & 23,5 & 23,6 & $-0,1$ \\
\cline { 2 - 5 } 8 & C8 Test. & 29,5 & 28,2 & 1,3 \\
\cline { 2 - 5 } & C4 Test. & 22,8 & 20,8 & 2,0 \\
\cline { 2 - 5 } 10 & C2 Test. & 45,7 & 43,4 & 2,3 \\
\cline { 2 - 5 } & & & &
\end{tabular}

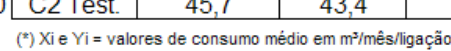

(**) C1 Test a C10 Test = áreas testemunha de VRP Automática

Posição

\begin{tabular}{|c|c|c|c|}
\hline & \multicolumn{3}{|c|}{ Posiçao } \\
\hline & $1 \mathrm{Q}=$ & 3,0 & $-0,6$ \\
\hline Mediana: & $2 \mathrm{Q}=$ & 5,5 & $-0,3$ \\
\hline & $3 Q=$ & 8,0 & 1,3 \\
\hline & $4 Q=$ & 10,5 & 2,3 \\
\hline & $\| \mathrm{Q}=$ & 1,9 & \\
\hline & $\mathrm{L} 1=$ & $1 \mathrm{Q}-1,5 \| \mathrm{Q}:$ & $-3,5$ \\
\hline & $\mathrm{L} 2=$ & $1 \mathrm{Q}-3,0 \| \mathrm{Q}:$ & $-6,3$ \\
\hline & $\mathrm{U} 1=$ & $3 \mathrm{Q}+1,5 \| \mathrm{Q}$ & 4,2 \\
\hline & $\mathrm{U} 2=$ & $3 \mathrm{Q}+3,0 \| \mathrm{Q}$ & 1 \\
\hline
\end{tabular}

$-0,3$

Não foram identificados "outliers" nessa análise.
MÉDIA:

AMPLITUDE: $\quad 3,3$

N ${ }^{\circ}$ CLASSES:

FAIXA: $\quad 1,0$

1,1

$\begin{array}{ccccc}\text { Classe } & \text { Consumo } & \text { ni } & \text { fi } & \text { fac } \\ 1 & -1,0 \text { a } 0,1 & 7 & 0,70 & 0,70 \\ 2 & 0,1 \text { a } 1,2 & 0 & 0,00 & 0,70 \\ 3 & 1,2 \text { a } 2,3 & 3 & 0,30 & 1,00\end{array}$

onde: $\mathrm{ni}=\mathrm{n}^{0}$ de ocorrências em cada classe de consumo $\mathrm{fi}=$ freqüência relativa do $n^{0}$ de ocorrência/classe $\mathrm{fac}=$ freqüência acumulada do $n^{0}$ de ocorrências

$\begin{array}{lc}\text { onde: } & \\ 1 \mathrm{Q}= & \left(1^{\circ} \text { quartil) }\right. \\ 2 \mathrm{Q}= & \left(2^{\circ} \text { quartil) }\right. \\ 3 \mathrm{Q}= & \left(3^{\circ} \text { quartil) }\right. \\ 4 \mathrm{Q}= & \left(4^{\circ} \text { quartil) }\right. \\ \mathrm{IQ}= & \text { (intervalo interquartil) } \\ \mathrm{L} 1= & \text { grade interna inferior } \\ \mathrm{L} 2= & \text { grade externa inferior } \\ \mathrm{U} 1= & \text { grade interna superior } \\ \mathrm{U} 2= & \text { grade externa superior }\end{array}$


BOX-PLOT COM CERCAS, DOS VALORES DE CONSUMO MÉDIO NAS ÁREAS TESTEMUNHA DE VRP, PARA IDENTIFICAÇÃO DE OUTLIERS

\begin{tabular}{|c|c|c|c|c|}
\cline { 2 - 5 } & AREA & ANTES $(\mathrm{Xi})$ & APÓS $(\mathrm{Yi})$ & $(\mathrm{Xi}-\mathrm{Yi})$ \\
\cline { 2 - 5 } & C6 Test. & 15,1 & 15,9 & $-0,8$ \\
\cline { 2 - 5 } 2 & C5 Test. & 13,9 & 14,6 & $-0,7$ \\
\cline { 2 - 5 } 3 & C1 Test. & 25,2 & 25,8 & $-0,7$ \\
\cline { 2 - 5 } & C3 Test. & 37,6 & 38,2 & $-0,6$ \\
\cline { 2 - 5 } 5 & C10 Test. & 23,0 & 23,3 & $-0,3$ \\
\hline & C7 Test. & 16,2 & 16,3 & $-0,2$ \\
\cline { 2 - 5 } 7 & C9 Test. & 23,4 & 23,5 & $-0,1$ \\
\cline { 2 - 5 } 8 & C8 Test. & 29,2 & 27,9 & 1,3 \\
\cline { 2 - 5 } 9 & C4 Test. & 22,7 & 20,5 & 2,2 \\
\cline { 2 - 5 } 10 & C2 Test. & 46,3 & 43,9 & 2,4 \\
\cline { 2 - 5 } & & &
\end{tabular}

(*) $\mathrm{Xi}$ e $\mathrm{Yi}=$ valores de consumo médio em $\mathrm{m}^{3} / \mathrm{mês} /$ ligação $\left.{ }^{* *}\right)$ C1 Test a C10 Test $=$ áreas testemunha de VRP Automática

\begin{tabular}{rrrr}
\multicolumn{1}{c}{} & \multicolumn{3}{c}{ Posição } \\
\hline Mediana: & $2 \mathrm{Q}=$ & 3,0 & $-0,7$ \\
\hline & $3 \mathrm{Q}=$ & 5,5 & $-0,2$ \\
$\mathrm{4Q}=$ & 8,0 & 1,3 \\
& $\mathrm{IQ}=$ & 2,0 & \\
& $\mathrm{~L} 1=$ & 10,5 & $2,4,5 \| \mathrm{Q}:$ \\
& $\mathrm{L} 2=$ & $1 \mathrm{Q}-3,0 \| \mathrm{Q}:$ & $-3,7$ \\
& $\mathrm{U} 1=$ & $3 \mathrm{Q}+1,5 \| \mathrm{Q}$ & $-6,7$ \\
& $\mathrm{U} 2=$ & $3 \mathrm{Q}+3,0 \| \mathrm{Q}$ & 7,3 \\
Mediana: & & & $-0,2$
\end{tabular}

MÉDIA:

AMPLITUDE:

$N^{0}$ CLASSES

FAIXA:

Classe
1
2
3

onde: $\mathrm{ni}=\mathrm{n}^{0}$ de ocorrências em cada classe de consumo $\mathrm{fi}=$ freqüência relativa do $n^{0}$ de ocorrência/classe fac $=$ freqüência acumulada do $n^{0}$ de ocorrências

$\begin{array}{lc}\text { onde: } & \\ 1 \mathrm{Q}= & \left(1^{\circ} \text { quartil) }\right. \\ 2 \mathrm{Q}= & \left(2^{\circ} \text { quartil) }\right. \\ 3 \mathrm{Q}= & \left(3^{\circ} \text { quartil) }\right. \\ 4 \mathrm{Q}= & \left(4^{\circ} \text { quartil) }\right. \\ \mathrm{IQ}= & \text { (intervalo interquartil) } \\ \mathrm{L} 1= & \text { grade interna inferior } \\ \mathrm{L} 2= & \text { grade externa inferior } \\ \mathrm{U} 1= & \text { grade interna superior } \\ \mathrm{U} 2= & \text { grade externa superior }\end{array}$

Não foram identificados "outliers" nessa análise. 


\section{APÊNDICE C: PLANILHAS COM OS TESTES DE HIPÓTESES}

Para avaliação da tendência e significância estatística das diferenças entre médias de consumo, na situação antes e depois da entrada em operação de válvulas redutoras de pressão (VRPs), foram realizados testes paramétricos de hipóteses conhecidos por testes de t-pareado.

Neste apêndice, são apresentadas cópias das planilhas Excel onde foram feitas essas análises.

Obs.: todos os valores de média de consumo e de diferenças de média de consumo são dados em $\mathrm{m}^{3} / \mathrm{mês} /$ ligação. 
ANÁLISE 1: ÁREAS DE VRP E TESTEMUNHA

TESTE DE HIPÓTESE DAS MÉDIAS DE CONSUMO ANTES E APÓS A REDUÇÃO DE PRESSÃO PROVOCADA PELA INSTALAÇÃO DA VRP

\begin{tabular}{|c|c|c|c|c|c|c|}
\hline & VRP & ANTES (Xi) & APÓS (Yi) & $D i=(X i-Y i)$ & $\mathrm{Di}-\mathrm{MD}$ & $(\mathrm{Di}-\mathrm{MD})^{2}$ \\
\hline 1 & F14 Test. & 48,5 & 50,2 & $-1,8$ & $-2,3$ & 5,2 \\
\hline 2 & F15 Test. & 13,0 & 14,1 & $-1,2$ & $-1,6$ & 2,7 \\
\hline 3 & C6 Test. & 16,6 & 17,6 & $-1,0$ & $-1,5$ & 2,3 \\
\hline 4 & C5 & 16,8 & 17,8 & $-1,0$ & $-1,5$ & 2,2 \\
\hline 5 & C5 Test. & 16,8 & 17,6 & $-0,8$ & $-1,3$ & 1,8 \\
\hline 6 & C1 Test. & 36,1 & 36,8 & $-0,7$ & $-1,2$ & 1,5 \\
\hline 7 & F13 & 22,9 & 23,4 & $-0,5$ & $-1,0$ & 1,0 \\
\hline 8 & C6 & 16,3 & 16,9 & $-0,5$ & $-1,0$ & 1,0 \\
\hline 9 & F14 & 20,3 & 20,8 & $-0,5$ & $-1,0$ & 1,0 \\
\hline 10 & F8 & 26,1 & 26,3 & $-0,2$ & $-0,7$ & 0,5 \\
\hline 11 & C2 Test. & 88,0 & 88,1 & $-0,2$ & $-0,6$ & 0,4 \\
\hline 12 & F12 & 18,8 & 18,9 & $-0,1$ & $-0,6$ & 0,4 \\
\hline 13 & F1 & 15,8 & 16,0 & $-0,1$ & $-0,6$ & 0,4 \\
\hline 14 & C7 Test. & 19,3 & 19,3 & $-0,1$ & $-0,6$ & 0,3 \\
\hline 15 & F1 Test. & 15,9 & 15,8 & 0,1 & $-0,4$ & 0,2 \\
\hline 16 & C7 & 18,8 & 18,7 & 0,2 & $-0,3$ & 0,1 \\
\hline 17 & F3 Test. & 17,2 & 17,0 & 0,2 & $-0,3$ & 0,1 \\
\hline 18 & F17 Test. & 14,3 & 14,0 & 0,2 & $-0,2$ & 0,1 \\
\hline 19 & F3 & 17,3 & 17,0 & 0,2 & $-0,2$ & 0,1 \\
\hline 20 & $\mathrm{C} 4$ & 26,7 & 26,4 & 0,3 & $-0,2$ & 0,0 \\
\hline 21 & C9 Test. & 38,9 & 38,6 & 0,3 & $-0,2$ & 0,0 \\
\hline 22 & F9 Test. & 22,2 & 21,7 & 0,5 & 0,0 & 0,0 \\
\hline 23 & F10 & 43,9 & 43,4 & 0,5 & 0,0 & 0,0 \\
\hline 24 & F17 & 14,7 & 14,2 & 0,5 & 0,0 & 0,0 \\
\hline 25 & $\mathrm{C} 2$ & 34,1 & 33,5 & 0,5 & 0,0 & 0,0 \\
\hline 26 & F8 Test. & 22,6 & 22,0 & 0,6 & 0,1 & 0,0 \\
\hline 27 & $\mathrm{C} 3$ & 33,4 & 32,8 & 0,6 & 0,2 & 0,0 \\
\hline 28 & C9 & 43,6 & 42,9 & 0,7 & 0,2 & 0,0 \\
\hline 29 & F2 Test. & 18,5 & 17,8 & 0,7 & 0,2 & 0,1 \\
\hline 30 & F11 Test. & 14,5 & 13,7 & 0,8 & 0,3 & 0,1 \\
\hline 31 & F6 & 14,4 & 13,6 & 0,8 & 0,3 & 0,1 \\
\hline 32 & C4 Test. & 30,0 & 29,0 & 1,0 & 0,5 & 0,2 \\
\hline 33 & C1 & 70,7 & 69,7 & 1,0 & 0,5 & 0,3 \\
\hline 34 & F6 Test. & 15,4 & 14,3 & 1,1 & 0,6 & 0,4 \\
\hline 35 & F11 & 16,8 & 15,6 & 1,2 & 0,7 & 0,5 \\
\hline 36 & F7 Test. & 19,7 & 18,4 & 1,2 & 0,8 & 0,6 \\
\hline 37 & F4 Test. & 19,7 & 18,4 & 1,3 & 0,8 & 0,6 \\
\hline 38 & $\mathrm{~F} 2$ & 20,3 & 19,0 & 1,3 & 0,8 & 0,7 \\
\hline 39 & F7 & 18,9 & 17,5 & 1,4 & 0,9 & 0,9 \\
\hline 40 & F16 Test. & 16,3 & 14,9 & 1,5 & 1,0 & 0,9 \\
\hline 41 & F10 Test. & 43,6 & 42,1 & 1,5 & 1,0 & 1,0 \\
\hline 42 & C8 Test. & 83,5 & 82,0 & 1,5 & 1,0 & 1,0 \\
\hline 43 & F13 Test. & 54,2 & 52,6 & 1,6 & 1,1 & 1,1 \\
\hline 44 & F16 & 16,3 & 14,7 & 1,6 & 1,1 & 1,2 \\
\hline 45 & F12 Test. & 22,6 & 21,0 & 1,6 & 1,1 & 1,2 \\
\hline 46 & $\mathrm{~F} 4$ & 18,9 & 17,1 & 1,7 & 1,2 & 1,6 \\
\hline 47 & F5 & 30,1 & 28,3 & 1,8 & 1,3 & 1,7 \\
\hline 48 & F9 & 24,7 & 22,3 & 2,5 & 2,0 & 3,9 \\
\hline
\end{tabular}

(*) $\mathrm{X}_{\mathrm{i}}$ Y Yi valores médios de consumo em ms/mês/ligação

(**) F1 a F15: áreas com VRP Fixa

\section{Caracteristicas de Di: AMPLITUDE: 4,3 MÉDIA (MD): 0,5 MEDIANA: 0,5}

$\mathrm{H} 0: \mathrm{MD}=0$ (o consumo médio, antes e após a data de entrada em operação da VRP, não variou) $\mathrm{H} 1: \mathrm{MD} \neq 0$ (o consumo médio, antes e após a data de entrada em operação da VRP, variou)

Média: $\mathrm{MD}=0,5$

Variância: $\mathrm{SD}^{2}=\sum(\mathrm{Di}-\mathrm{MD})^{2} /(\mathrm{n}-1)=$

Desvio Padrão: $\mathrm{SD}=\sqrt{ } 0,8=\quad 0,9$

$39,3 / 47=\quad 0,8$

$$
\mathrm{t}_{\mathrm{obs}}=\mathrm{MD} /(\mathrm{SD} / \sqrt{ }(\mathrm{n}))=\quad 0,5 / 0,91 / \sqrt{ } 48=3,738
$$

Na tabela de Distribuição Student:

graus de liberdade: gl: $(n-1)=47$

nivel de significância: $\alpha=0,01$

$t_{\text {crtico: }}:$ tc $=2,680$

Como $\mathrm{t}_{\mathrm{obs}}=3,738$ se encontra fora do intervalo de confiança $-\mathrm{tc}=-2,680$ e tc $=2,680$, podemos rejeitar a

hipótese $\mathrm{H} 0$ de que o consumo antes e após a data de entrada em operação da VRP não variou,

quando consideradas as áreas de VRP e as áreas testemunha (sem influência da VRP)

Dessa forma, constata-se uma tendência à redução do consumo médio (variação positiva da relação Antes - Após), na média geral das áreas avaliadas 


\section{ANÁLISE 2: ÁREAS DE VRP}

TESTE DE HIPÓTESE DAS MÉDIAS DE CONSUMO ANTES E APÓS A REDUÇÃO DE PRESSÃO PROVOCADA PELA INSTALAÇÃO DA VRP

\begin{tabular}{|c|c|c|c|c|c|c|}
\hline & VRP & ANTES (Xi) & APÓS (Yi) & $D i=(X i-Y i)$ & Di - MD & $(\mathrm{Di}-\mathrm{MD})^{2}$ \\
\hline 1 & C5 & 16,8 & 17,8 & $-1,0$ & $-1,6$ & 2,5 \\
\hline 2 & F13 & 22,9 & 23,4 & $-0,5$ & $-1,1$ & 1,2 \\
\hline 3 & C6 & 16,3 & 16,9 & $-0,5$ & $-1,1$ & 1,2 \\
\hline 4 & F14 & 20,3 & 20,8 & $-0,5$ & $-1,1$ & 1,1 \\
\hline 5 & F8 & 26,1 & 26,3 & $-0,2$ & $-0,8$ & 0,6 \\
\hline 6 & F12 & 18,8 & 18,9 & $-0,1$ & $-0,7$ & 0,5 \\
\hline 7 & F1 & 15,8 & 16,0 & $-0,1$ & $-0,7$ & 0,5 \\
\hline 8 & C7 & 18,8 & 18,7 & 0,2 & $-0,4$ & 0,2 \\
\hline 9 & F3 & 17,3 & 17,0 & 0,2 & $-0,3$ & 0,1 \\
\hline 10 & $\mathrm{C} 4$ & 26,7 & 26,4 & 0,3 & $-0,3$ & 0,1 \\
\hline 11 & F10 & 43,9 & 43,4 & 0,5 & $-0,1$ & 0,0 \\
\hline 12 & F17 & 14,7 & 14,2 & 0,5 & $-0,1$ & 0,0 \\
\hline 13 & $\mathrm{C} 2$ & 34,1 & 33,5 & 0,5 & 0,0 & 0,0 \\
\hline 14 & C3 & 33,4 & 32,8 & 0,6 & 0,1 & 0,0 \\
\hline 15 & $\mathrm{C9}$ & 43,6 & 42,9 & 0,7 & 0,1 & 0,0 \\
\hline 16 & F6 & 14,4 & 13,6 & 0,8 & 0,2 & 0,0 \\
\hline 17 & $\mathrm{C} 1$ & 70,7 & 69,7 & 1,0 & 0,4 & 0,2 \\
\hline 18 & F11 & 16,8 & 15,6 & 1,2 & 0,6 & 0,4 \\
\hline 19 & F2 & 20,3 & 19,0 & 1,3 & 0,7 & 0,5 \\
\hline 20 & F7 & 18,9 & 17,5 & 1,4 & 0,9 & 0,7 \\
\hline 21 & F16 & 16,3 & 14,7 & 1,6 & 1,0 & 1,0 \\
\hline 22 & F4 & 18,9 & 17,1 & 1,7 & 1,2 & 1,3 \\
\hline 23 & F5 & 30,1 & 28,3 & 1,8 & 1,2 & 1,5 \\
\hline 24 & F9 & 24,7 & 22,3 & 2,5 & 1,9 & 3,6 \\
\hline
\end{tabular}

(*) F1 a F15: áreas com VRP Fixa

\section{Características de Di: AMPLITUDE: 3,5 \\ MÉDIA (MD): 0,6 \\ MEDIANA: $\quad 0,5$}

H0: MD = 0 (o consumo médio, antes e após a data de entrada em operação da VRP, não variou) $\mathrm{H} 1: \mathrm{MD} \neq 0$ (o consumo médio, antes e após a data de entrada em operação da VRP, variou)

Média: $\mathrm{MD}=0,6$

Variância: $\mathrm{SD}^{2}=\sum(\mathrm{Di}-\mathrm{MD})^{2} /(\mathrm{n}-1)=\quad 17,4 / 23=\quad 0,8$
Desvio Padrão: $\mathrm{SD}=\sqrt{0,8}=\quad 0,87$

$$
\mathrm{t}_{\mathrm{obs}}=\mathrm{MD} /(\mathrm{SD} / \sqrt{ }(\mathrm{n}))=\quad 0,6 / 0,87 / \sqrt{ } 24=3,262
$$

Na tabela de Distribuição Student:

graus de liberdade: $\mathrm{gl}:(\mathrm{n}-1)=23$

nivel de significância: $\alpha=0,01$

$$
t_{\text {crtico: }} \text { tc }=2,807
$$

Como tobs $=3,262$ se encontra fora do intervalo de confiança $-\mathrm{tc}=-2,807$ e tc $=2,807$, podemos rejeitar a hipótese $\mathrm{H} 0$ de que o consumo antes e após a data de entrada em operação da VRP não variou, quando consideradas as áreas de VRP. 
ANÁLISE 3: ÁREAS TESTEMUNHA

TESTE DE HIPÓTESE DAS MÉDIAS DE CONSUMO ANTES E APÓS A REDUÇÃO DE PRESSÃO PROVOCADA PELA INSTALAÇÃO DA VRP

\begin{tabular}{|c|c|c|c|c|c|c|}
\hline & VRP & ANTES (Xi) & APÓS (Yi) & $\mathrm{Di}=(\mathrm{Xi}-\mathrm{Yi})$ & $\mathrm{Di}-\mathrm{MD}$ & $(\mathrm{Di}-\mathrm{MD})^{2}$ \\
\hline 1 & F14 Test. & 48,5 & 50,2 & $-1,8$ & $-2,2$ & 4,8 \\
\hline 2 & F15 Test. & 13,0 & 14,1 & $-1,2$ & $-1,6$ & 2,4 \\
\hline 3 & \begin{tabular}{|l} 
C6 Test. \\
\end{tabular} & 16,6 & 17,6 & $-1,0$ & $-1,4$ & 2,1 \\
\hline 4 & C5 Test. & 16,8 & 17,6 & $-0,8$ & $-1,2$ & 1,5 \\
\hline 5 & C1 Test. & 36,1 & 36,8 & $-0,7$ & $-1,2$ & 1,3 \\
\hline 6 & C2 Test. & 88,0 & 88,1 & $-0,2$ & $-0,6$ & 0,3 \\
\hline 7 & C7 Test. & 19,3 & 19,3 & $-0,1$ & $-0,5$ & 0,2 \\
\hline 8 & F1 Test. & 15,9 & 15,8 & 0,1 & $-0,3$ & 0,1 \\
\hline 9 & F3 Test. & 17,2 & 17,0 & 0,2 & $-0,2$ & 0,0 \\
\hline 10 & F17 Test. & 14,3 & 14,0 & 0,2 & $-0,2$ & 0,0 \\
\hline 11 & C9 Test. & 38,9 & 38,6 & 0,3 & $-0,1$ & 0,0 \\
\hline 12 & F9 Test. & 22,2 & 21,7 & 0,5 & 0,1 & 0,0 \\
\hline 13 & F8 Test. & 22,6 & 22,0 & 0,6 & 0,2 & 0,0 \\
\hline 14 & F2 Test. & 18,5 & 17,8 & 0,7 & 0,3 & 0,1 \\
\hline 15 & F11 Test. & 14,5 & 13,7 & 0,8 & 0,4 & 0,1 \\
\hline 16 & C4 Test. & 30,0 & 29,0 & 1,0 & 0,5 & 0,3 \\
\hline 17 & F6 Test. & 15,4 & 14,3 & 1,1 & 0,7 & 0,5 \\
\hline 18 & F7 Test. & 19,7 & 18,4 & 1,2 & 0,8 & 0,7 \\
\hline 19 & F4 Test. & 19,7 & 18,4 & 1,3 & 0,9 & 0,8 \\
\hline 20 & \begin{tabular}{|l} 
F16 Test. \\
\end{tabular} & 16,3 & 14,9 & 1,5 & 1,0 & 1,1 \\
\hline 21 & F10 Test. & 43,6 & 42,1 & 1,5 & 1,1 & 1,2 \\
\hline 22 & C8 Test. & 83,5 & 82,0 & 1,5 & 1,1 & 1,2 \\
\hline 23 & \begin{tabular}{|l} 
F13 Test. \\
F13 Test
\end{tabular} & 54,2 & 52,6 & 1,6 & 1,2 & 1,3 \\
\hline 24 & F12 Test. & 22,6 & 21,0 & 1,6 & 1,2 & 1,4 \\
\hline
\end{tabular}

$\left.{ }^{(\star *}\right)$ F1 a F15: áreas com VRP Fixa

Caracteristicas de Di: AMPLITUDE: 3,4

MÉDIA (MD): 0,4

MEDIANA: $\quad 0,5$

H0: MD = 0 (o consumo médio, antes e após a data de entrada em operação da VRP, não variou) $\mathrm{H} 1: \mathrm{MD} \neq 0$ (o consumo médio, antes e após a data de entrada em operação da VRP, variou)

Média: $\mathrm{MD}=0,4$

$$
\begin{aligned}
& \text { Variância: } \mathrm{SD}^{2}=\sum(\mathrm{Di}-\mathrm{MD})^{2} /(\mathrm{n}-1)=\quad 21,6 / 23=\quad 0,9 \\
& \text { Desvio Padrão: } \mathrm{SD}=\sqrt{1,3}=\quad 0,97 \\
& \mathrm{t}_{\mathrm{obs}}=\mathrm{MD} /(\mathrm{SD} / \sqrt{ }(\mathrm{n}))=\quad 0,4 / 0,97 / \sqrt{ } 24=2,062
\end{aligned}
$$

Na tabela de Distribuição Student:

graus de liberdade: $\mathrm{gl}:(\mathrm{n}-1)=23$

nivel de significância: $\alpha=0,05$

$$
t_{\text {critico: }}: \text { tc }=2,069
$$

Como tobs $=2,062$ se encontra dentro do intervalo de confiança - tc $=-2,807$ e tc $=2,807$, não podemos rejeitar a hipótese $\mathrm{H} 0$ de que o consumo antes e após a data de entrada em operação da VRP, não variou, quando consideradas as áreas testemunha (sem influência direta de VRP), com um grau de confiança de $95 \%$. 


\section{ANÁLISE 4: ÁREAS DE VRP COM SAÍDA FIXA DE PRESSÃO TESTE DE HIPÓTESE DAS MÉDIAS DE CONSUMO ANTES E APÓS A REDUÇÃO DE PRESSÃO PROVOCADA PELA INSTALAÇÃO DA VRP COM SAIDA DE PRESSÃO FIXA}

\begin{tabular}{|c|c|c|c|c|c|c|}
\hline & VRP & ANTES (Xi) & APÓS (Yi) & $\mathrm{Di}=(\mathrm{Xi}-\mathrm{Yi})$ & Di -MD & $(\mathrm{Di}-\mathrm{MD})^{2}$ \\
\hline 1 & F15 & 20,1 & 22,3 & $-2,3$ & $-2,8$ & 8,0 \\
\hline 2 & F13 & 22,9 & 23,4 & $-0,5$ & $-1,1$ & 1,2 \\
\hline 3 & F14 & 20,3 & 20,8 & $-0,5$ & $-1,1$ & 1,1 \\
\hline 4 & F8 & 26,1 & 26,3 & $-0,2$ & $-0,8$ & 0,6 \\
\hline 5 & F12 & 18,8 & 18,9 & $-0,1$ & $-0,7$ & 0,5 \\
\hline 6 & $\mathrm{~F} 1$ & 15,8 & 16,0 & $-0,1$ & $-0,7$ & 0,5 \\
\hline 7 & F3 & 17,3 & 17,0 & 0,2 & $-0,3$ & 0,1 \\
\hline 8 & F10 & 43,9 & 43,4 & 0,5 & $-0,1$ & 0,0 \\
\hline 9 & F17 & 14,7 & 14,2 & 0,5 & $-0,1$ & 0,0 \\
\hline 10 & F6 & 14,4 & 13,6 & 0,8 & 0,2 & 0,0 \\
\hline 11 & F11 & 16,8 & 15,6 & 1,2 & 0,6 & 0,4 \\
\hline 12 & $\mathrm{~F} 2$ & 20,3 & 19,0 & 1,3 & 0,7 & 0,5 \\
\hline 13 & F7 & 18,9 & 17,5 & 1,4 & 0,9 & 0,7 \\
\hline 14 & F16 & 16,3 & 14,7 & 1,6 & 1,0 & 1,0 \\
\hline 15 & $\mathrm{~F} 4$ & 18,9 & 17,1 & 1,7 & 1,2 & 1,4 \\
\hline 16 & F5 & 30,1 & 28,3 & 1,8 & 1,2 & 1,5 \\
\hline 17 & F9 & 24,7 & 22,3 & 2,5 & 1,9 & 3,6 \\
\hline
\end{tabular}

$\left.{ }^{*}\right) \mathrm{Xi}$ e $\mathrm{Yi}$ : valores médios de consumo em $\mathrm{m}^{3} / \mathrm{mês} /$ ligação

$\sum$ :

21,3

${ }^{(*)}$ F1 a F15: áreas com VRP Fixa

Caracteristicas de Di: AMPLITUDE: 4,7

MÉDIA (MD): 0,6

MEDIANA: $\quad 0,5$

H0: MD = 0 (o consumo médio, antes e após a data de entrada em operação da VRP, não variou) H1: MD $\neq 0$ (o consumo médio, antes e após a data de entrada em operação da VRP, variou)

$$
\begin{aligned}
& \text { Média: } \mathrm{MD}=0,6 \\
& \begin{array}{l}
\text { Variância: } \mathrm{SD}^{2}=\sum(\mathrm{Di}-\mathrm{MD})^{2} /(\mathrm{n}-1)=\quad 21,3 / 16= \\
\text { Desvio Padrão: } \mathrm{SD}=\sqrt{1,3}=\quad 1,15 \\
\mathrm{t}_{\mathrm{obs}}=\mathrm{MD} /(\mathrm{SD} / \sqrt{ }(\mathrm{n}))=
\end{array} \quad 0,6 / 1,15 / \sqrt{ } 17=2,069
\end{aligned}
$$

Na tabela de Distribuição Student:

graus de liberdade: gl: $(n-1)=16$

nivel de significância: $\alpha=0,05$

$$
t_{\text {critico: }}: t_{c}=2,120
$$

Como $_{\mathrm{obs}}=2,069$ se encontra dentro do intervalo de confiança $-\mathrm{tc}=-2,120$ e tc $=2,120$, não podemos rejeitar a hipótese $\mathrm{H} 0$ de que o consumo antes e após a data de entrada em operação da VRP não variou, quando consideradas as áreas de VRP com saída fixa, com um grau de confiança de $95 \%$. 
ANÁLISE 4.1: ÁREAS DE VRP SAÍDA FIXA (até 12 econ./Lig.) TESTE DE HIPÓTESE DAS MÉDIAS DE CONSUMO ANTES E APÓS A REDUÇÃO DE PRESSÃO PROVOCADA PELA INSTALAÇÃO DA VRP COM SAIDA DE PRESSÃO FIXA

\begin{tabular}{|c|c|c|c|c|c|c|}
\hline & VRP & ANTES (Xi) & APÓS (Yi) & $D i=(X i-Y i)$ & $\mathrm{Di}-\mathrm{MD}$ & $(\mathrm{Di}-\mathrm{MD})^{2}$ \\
\hline 1 & F15 & 13,5 & 15,3 & $-1,8$ & $-2,4$ & 5,8 \\
\hline 2 & F13 & 22,9 & 23,4 & $-0,5$ & $-1,2$ & 1,4 \\
\hline 3 & F14 & 20,3 & 20,8 & $-0,5$ & $-1,1$ & 1,3 \\
\hline 4 & F8 & 26,1 & 26,3 & $-0,2$ & $-0,8$ & 0,7 \\
\hline 5 & $\mathrm{~F} 1$ & 15,8 & 16,0 & $-0,1$ & $-0,8$ & 0,6 \\
\hline 6 & F12 & 18,8 & 18,9 & $-0,1$ & $-0,8$ & 0,6 \\
\hline 7 & F3 & 17,3 & 17,0 & 0,2 & $-0,4$ & 0,2 \\
\hline 8 & F17 & 14,7 & 14,2 & 0,5 & $-0,2$ & 0,0 \\
\hline 9 & F6 & 14,4 & 13,6 & 0,8 & 0,1 & 0,0 \\
\hline 10 & F11 & 16,8 & 15,6 & 1,2 & 0,5 & 0,3 \\
\hline 11 & $\mathrm{~F} 2$ & 20,2 & 18,9 & 1,3 & 0,7 & 0,4 \\
\hline 12 & $\mathrm{~F} 5$ & 26,6 & 25,2 & 1,4 & 0,7 & 0,5 \\
\hline 13 & F7 & 18,9 & 17,5 & 1,4 & 0,8 & 0,6 \\
\hline 14 & F10 & 38,5 & 37,0 & 1,5 & 0,8 & 0,7 \\
\hline 15 & F16 & 16,3 & 14,7 & 1,6 & 1,0 & 0,9 \\
\hline 16 & $\mathrm{~F} 4$ & 18,9 & 17,1 & 1,7 & 1,1 & 1,2 \\
\hline 17 & F9 & 24,1 & 21,6 & 2,5 & 1,9 & 3,5 \\
\hline
\end{tabular}

(*) Xi e Yi: valores médios de consumo em $\mathrm{m}^{3} / \mathrm{mês} /$ ligação

$\left.{ }^{* *}\right)$ F1 a F15: áreas com VRP Fixa

Características de Di: AMPLITUDE: 4,3

MÉDIA (MD): 0,6

MEDIANA: $\quad 0,8$

$\mathrm{H} 0: \mathrm{MD}=0$ (o consumo médio, antes e após a data de entrada em operação da VRP, não variou) $\mathrm{H} 1: \mathrm{MD} \neq 0$ (o consumo médio, antes e após a data de entrada em operação da VRP, variou)

Média: $\mathrm{MD}=0,6$

Variância: $\mathrm{SD}^{2}=\sum(\mathrm{Di}-\mathrm{MD})^{2} /(\mathrm{n}-1)=\quad 18,7 / 16=\quad 1,2$

Desvio Padrão: $\mathrm{SD}=\sqrt{1,2}=1,08$

$$
\mathrm{t}_{\mathrm{obs}}=\mathrm{MD} /(\mathrm{SD} / \sqrt{ }(\mathrm{n}))=\quad 0,65 / 1,08 / \sqrt{ } 17=2,461
$$

Na tabela de Distribuição Student:

graus de liberdade: $\mathrm{gl}:(\mathrm{n}-1)=16$

nivel de significância: $\alpha=0,01$

$t_{\text {critico: }}$ tc $=2,921$

Como tobs $=2,461$ se encontra dentro do intervalo de confiança - tc $=-2,921$ e tc $=2,921$, não podemos rejeitar a hipótese $\mathrm{H} 0$ de que o consumo antes e após a data de entrada em operação da VRP não variou, quando consideradas as áreas de VRP com saída fixa, com um grau de confiança de $99 \%$.

Na tabela de Distribuição Student:

graus de liberdade: $\mathrm{gl}:(\mathrm{n}-1)=16$

nivel de significância: $\alpha=0,05$

$t_{\text {crtico: }}: t_{c}=2,120$

Como tobs $=2,461$ se encontra fora do intervalo de confianca $-\mathrm{tc}=-2,120$ e tc $=2,120$, podemos rejeitar a hipótese $\mathrm{H} 0$ de que o consumo antes e após a data de entrada em operação da VRP, não variou, quando consideradas as áreas de VRP com saida fixa, com um grau de confiança de $95 \%$

Dessa forma, quando se analisa a série de médias de consumo, em referência, com um grau de confiança de $95 \%$, verifica-se uma tendência à redução do consumo médio (variação positiva da relação Antes - Após), na média geral das áreas avaliadas, fato que não pode ser afirmado com um grau de confiança de $99 \%$ 
ANÁLISE 4.2: ÁREAS DE VRP SAÍDA FIXA (até 3 econ./Lig.)

TESTE DE HIPÓTESE DAS MÉDIAS DE CONSUMO ANTES E APÓS A REDUÇÃO DE PRESSÃO PROVOCADA PELA INSTALAÇÃO DA VRP

\begin{tabular}{|c|c|c|c|c|c|c|}
\hline & VRP & ANTES (Xi) & APÓS (Yi) & $D i=(X i-Y i)$ & $\mathrm{Di}-\mathrm{MD}$ & $(\mathrm{Di}-\mathrm{MD})^{2}$ \\
\hline 1 & F15 & 13,5 & 15,3 & $-1,8$ & $-2,4$ & 5,8 \\
\hline 2 & F13 & 21,8 & 22,2 & $-0,4$ & $-1,1$ & 1,2 \\
\hline 3 & F14 & 20,0 & 20,4 & $-0,4$ & $-1,1$ & 1,2 \\
\hline 4 & F8 & 26,2 & 26,4 & $-0,3$ & $-0,9$ & 0,8 \\
\hline 5 & $\mathrm{~F} 1$ & 15,6 & 15,8 & $-0,1$ & $-0,8$ & 0,6 \\
\hline 6 & F12 & 18,5 & 18,6 & $-0,1$ & $-0,7$ & 0,5 \\
\hline 7 & $\mathrm{~F} 3$ & 17,3 & 17,0 & 0,2 & $-0,4$ & 0,2 \\
\hline 8 & $\mathrm{~F} 17$ & 14,7 & 14,2 & 0,5 & $-0,2$ & 0,0 \\
\hline 9 & F6 & 14,4 & 13,6 & 0,8 & 0,1 & 0,0 \\
\hline 10 & F11 & 16,5 & 15,3 & 1,2 & 0,6 & 0,4 \\
\hline 11 & $\mathrm{~F} 2$ & 19,5 & 18,2 & 1,3 & 0,7 & 0,4 \\
\hline 12 & F5 & 26,6 & 25,2 & 1,4 & 0,7 & 0,5 \\
\hline 13 & $\mathrm{~F} 10$ & 36,5 & 35,1 & 1,4 & 0,8 & 0,6 \\
\hline 14 & $\mathrm{~F} 7$ & 18,7 & 17,2 & 1,4 & 0,8 & 0,6 \\
\hline 15 & F16 & 16,3 & 14,7 & 1,6 & 1,0 & 0,9 \\
\hline 16 & $\mathrm{~F} 4$ & 18,3 & 16,6 & 1,7 & 1,0 & 1,1 \\
\hline 17 & F9 & 24,1 & 21,6 & 2,5 & 1,8 & 3,4 \\
\hline
\end{tabular}

(*) Xi e Yi: valores médios de consumo em $\mathrm{m}^{3} /$ mês/ligação

$\Sigma$

${ }^{(*)}$ F1 a F15: áreas com VRP Fixa

Caracteristicas de Di: AMPLITUDE: 4,3

MÉDIA (MD): 0,6

MEDIANA: $\quad 0,8$

H0: MD = 0 (o consumo médio, antes e após a data de entrada em operação da VRP, não variou) $\mathrm{H} 1: \mathrm{MD} \neq 0$ (o consumo médio, antes e após a data de entrada em operação da VRP, variou)

Média: $\mathrm{MD}=0,6$

Variância: $\mathrm{SD}^{2}=\sum(\mathrm{Di}-\mathrm{MD})^{2} /(\mathrm{n}-1)=\quad 18,2 / 16=\quad 1,1$

Desvio Padrão: $\mathrm{SD}=\sqrt{ } 1,1=1,07$

$$
\mathrm{t}_{\mathrm{obs}}=\mathrm{MD} /(\mathrm{SD} / \sqrt{ }(\mathrm{n}))=\quad 0,6 / 1,07 / \sqrt{ } 17=2,495
$$

Na tabela de Distribuição Student:

graus de liberdade: gl: $(n-1)=16$

nível de significância: $\alpha=0,01$

$$
t_{\text {crítico: }} \text { tc }=2,921
$$

Como tobs $=2,495$ se encontra dentro do intervalo de confiança - tc $=-2,921$ e tc $=2,921$, não podemos rejeitar a hipótese $\mathrm{H} 0$ de que o consumo antes e após a data de entrada em operação da VRP não variou, quando consideradas as áreas de VRP com saida fixa, com um grau de confiança de $99 \%$.

Na tabela de Distribuição Student:

graus de liberdade: $\mathrm{gl}:(\mathrm{n}-1)=16$

nivel de significância: $\alpha=0,05$

$$
t_{\text {critico: }}: t c=2,120
$$

Como tobs $=2,495$ se encontra fora do intervalo de confiança - tc $=-2,120$ e tc $=2,120$, podemos rejeitar a hipótese $\mathrm{H} 0$ de que o consumo antes e após a data de entrada em operação da VRP, não variou, quando consideradas as áreas de VRP com saida fixa, com um grau de confiança de $95 \%$.

Dessa forma, quando se analisa a série de médias de consumo, em referência, com um grau de confiança de $95 \%$, verifica-se uma tendência à redução do consumo médio (variação positiva da relação Antes - Após), na média geral das áreas avaliadas, fato que não pode ser afirmado com um grau de confiança de $99 \%$. 
ANÁLISE 4.3: ÁREAS DE VRP SAÍDA FIXA (1 econ./Lig.)

TESTE DE HIPÓTESE DAS MÉDIAS DE CONSUMO ANTES E APÓS A REDUÇÃO DE PRESSÃO PROVOCADA PELA INSTALAÇÃO DA VRP

\begin{tabular}{|c|c|c|c|c|c|c|}
\hline & VRP & ANTES (Xi) & APÓS (Yi) & $D i=(X i-Y i)$ & $\mathrm{Di}-\mathrm{MD}$ & $(\mathrm{Di}-\mathrm{MD})^{2}$ \\
\hline 1 & F15 & 12,8 & 14,4 & $-1,7$ & $-2,3$ & 5,1 \\
\hline 2 & F13 & 19,8 & 20,1 & $-0,3$ & $-0,9$ & 0,9 \\
\hline 3 & F14 & 19,5 & 19,8 & $-0,3$ & $-0,9$ & 0,8 \\
\hline 4 & F12 & 17,4 & 17,7 & $-0,3$ & $-0,9$ & 0,8 \\
\hline 5 & F1 & 13,9 & 14,1 & $-0,2$ & $-0,8$ & 0,7 \\
\hline 6 & F8 & 26,0 & 26,2 & $-0,2$ & $-0,8$ & 0,6 \\
\hline 7 & F3 & 17,3 & 17,0 & 0,2 & $-0,4$ & 0,1 \\
\hline 8 & F17 & 13,9 & 13,3 & 0,6 & 0,0 & 0,0 \\
\hline 9 & F6 & 13,8 & 13,1 & 0,7 & 0,1 & 0,0 \\
\hline 10 & F11 & 14,6 & 13,6 & 1,0 & 0,4 & 0,1 \\
\hline 11 & F16 & 15,0 & 13,9 & 1,1 & 0,5 & 0,2 \\
\hline 12 & F2 & 18,0 & 16,7 & 1,3 & 0,7 & 0,4 \\
\hline 13 & F7 & 17,8 & 16,5 & 1,3 & 0,7 & 0,5 \\
\hline 14 & F5 & 26,4 & 25,0 & 1,4 & 0,8 & 0,6 \\
\hline 15 & F10 & 36,4 & 35,0 & 1,4 & 0,8 & 0,7 \\
\hline 16 & F4 & 17,1 & 15,5 & 1,6 & 1,0 & 1,0 \\
\hline 17 & F9 & 24,3 & 21,6 & 2,7 & 2,1 & 4,4 \\
\hline
\end{tabular}

${ }^{(*)} \mathrm{Xi}$ e Yi: valores médios de consumo em $\mathrm{m}^{3} / \mathrm{mês} /$ ligação

$\Sigma$

$\left.{ }^{(*}\right)$ F1 a F15: áreas com VRP Fixa

Características de Di: AMPLITUDE: 4,3

MÉDIA (MD): 0,6

MEDIANA: $\quad 0,7$

H0: MD = 0 (o consumo médio, antes e após a data de entrada em operação da VRP, não variou) $\mathrm{H} 1: \mathrm{MD} \neq 0$ (o consumo médio, antes e após a data de entrada em operação da VRP, variou)

Média: $\mathrm{MD}=0,6$

Desvio Padrão: $\mathrm{SD}=\sqrt{1,1}=1,03$

$16,9 / 16=\quad 1,1$

$$
\mathrm{t}_{\mathrm{obs}}=\mathrm{MD} /(\mathrm{SD} / \sqrt{ }(\mathrm{n}))=\quad 0,61 / 1,03 / \sqrt{ } 17=2,435
$$

Na tabela de Distribuição Student

graus de liberdade: $\mathrm{gl}:(\mathrm{n}-1)=16$

nivel de significância: $\alpha=0,01$

$t_{\text {critico: }}$ tc $=2,921$

Como tobs $=2,435$ se encontra dentro do intervalo de confiança $-\mathrm{tc}=-2,921$ e tc $=2,921$, não podemos rejeitar a hipótese $\mathrm{H} 0$ de que o consumo antes e após a data de entrada em operação da VRP não variou, quando consideradas as áreas de VRP com saida fixa, com um grau de confiança de $99 \%$.

Na tabela de Distribuição Student

$$
\begin{array}{r}
\text { graus de liberdade: } g l:(n-1)= \\
\text { nivel de significância: } \alpha=0,05 \\
t_{\text {crtico: }}: t c=2,120
\end{array}
$$

Como tobs $=2,435$ se encontra fora do intervalo de confiança - tc $=-2,120$ e tc $=2,120$, podemos rejeitar a hipótese $\mathrm{H} 0$ de que o consumo antes e após a data de entrada em operação da VRP, não variou, quando consideradas as áreas de VRP com saida fixa, com um grau de confiança de $95 \%$

Dessa forma, quando se analisa a série de médias de consumo, em referência, com um grau de confiança de $95 \%$, verifica-se uma tendência à redução do consumo médio (variação positiva da relação Antes - Após), na média geral das áreas avaliadas, fato que não pode ser afirmado com um grau de confiança de $99 \%$ 


\section{ANÁLISE 5: ÁREAS DE VRP - CONTROLE AUTOMÁTICO DE PRESSÃO TESTE DE HIPÓTESE DAS MÉDIAS DE CONSUMO ANTES E APÓS A REDUÇÃO DE PRESSÃO PROVOCADA PELA INSTALAÇÃO DA VRP}

\begin{tabular}{|c|c|c|c|c|c|c|}
\hline & VRP & ANTES (Xi) & APÓS (Yi) & $\mathrm{Di}=(\mathrm{Xi}-\mathrm{Yi})$ & $\mathrm{Di}-\mathrm{MD}$ & $(\mathrm{Di}-\mathrm{MD})^{2}$ \\
\hline 1 & $\mathrm{C} 5$ & 16,8 & 17,8 & $-1,0$ & $-1,2$ & 1,5 \\
\hline 2 & C6 & 16,3 & 16,9 & $-0,5$ & $-0,7$ & 0,5 \\
\hline 3 & C7 & 18,8 & 18,7 & 0,2 & $-0,1$ & 0,0 \\
\hline 4 & $\mathrm{C} 4$ & 26,7 & 26,4 & 0,3 & 0,1 & 0,0 \\
\hline 5 & $\mathrm{C} 2$ & 34,1 & 33,5 & 0,5 & 0,3 & 0,1 \\
\hline 6 & C3 & 33,4 & 32,8 & 0,6 & 0,4 & 0,2 \\
\hline 7 & C9 & 43,6 & 42,9 & 0,7 & 0,4 & 0,2 \\
\hline 8 & C1 & 70,7 & 69,7 & 1,0 & 0,8 & 0,6 \\
\hline
\end{tabular}

$\left.{ }^{*}\right) \mathrm{Xi}$ e $\mathrm{Yi}$ : valores médios de consumo em $\mathrm{m}^{3} / \mathrm{mês} /$ ligação

$\sum:$

3,1

${ }^{\left({ }^{*}\right)}$ F1 a F15: áreas com VRP Fixa

Caracteristicas de Di: AMPLITUDE: 2,0

MÉDIA (MD): 0,2

MEDIANA: $\quad 0,4$

H0: MD = 0 (o consumo médio, antes e após a data de entrada em operação da VRP, não variou) H1: MD $\neq 0$ (o consumo médio, antes e após a data de entrada em operação da VRP, variou)

$$
\text { Média: } M D=0,2
$$

Variância: $\mathrm{SD}^{2}=\sum(\mathrm{Di}-\mathrm{MD})^{2} /(\mathrm{n}-1)=$

Desvio Padrão: $\mathrm{SD}=\sqrt{1}, 1=0,67$

$$
3,1 / 7=\quad 0,4
$$

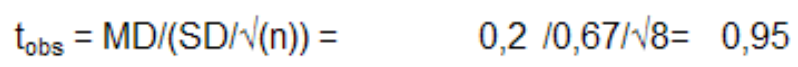

Na tabela de Distribuição Student:

$$
\text { graus de liberdade: } \text { gl: }(n-1)=7
$$

nivel de significância: $\alpha=0,05$

$$
t_{\text {critico: }}: t_{c}=2,365
$$

Como tobs $=0,951$ se encontra dentro do intervalo de confiança - tc $=-2,365$ e tc $=2,365$, não podemos rejeitar a hipótese $\mathrm{H} 0$ de que o consumo antes e após a data de entrada em operação da VRP, não variou, quando consideradas as áreas de VRP com controle automático de saída, com um grau de confiança de $95 \%$. 
ANÁLISE 5.1: ÁREAS DE VRP AUTOMÁTICA (até 12 econ./Lig.) TESTE DE HIPÓTESE DAS MÉDIAS DE CONSUMO ANTES E APÓS A REDUÇÃO DE PRESSÃO PROVOCADA PELA INSTALAÇÃO DA VRP

\begin{tabular}{|c|c|c|c|c|c|c|}
\hline & VRP & ANTES (Xi) & APÓS (Yi) & $\mathrm{Di}=(\mathrm{Xi}-\mathrm{Yi})$ & $\mathrm{Di}-\mathrm{MD}$ & $(\mathrm{Di}-\mathrm{MD})^{2}$ \\
\hline 1 & $\mathrm{C} 5$ & 16.5 & 17,5 & -1.0 & $-1,2$ & 1,5 \\
\hline 2 & C6 & 16,3 & 16,9 & $-0,5$ & $-0,7$ & 0,5 \\
\hline 3 & C7 & 17,8 & 17,8 & $-0,1$ & $-0,3$ & 0,1 \\
\hline 4 & C1 & 34,0 & 33,7 & 0,3 & 0,0 & 0,0 \\
\hline 5 & $\mathrm{C} 4$ & 26,7 & 26,4 & 0,3 & 0,1 & 0,0 \\
\hline 6 & C9 & 25,8 & 25,4 & 0,4 & 0,2 & 0,0 \\
\hline 7 & C3 & 29,9 & 29,5 & 0,4 & 0,2 & 0,0 \\
\hline 8 & C10 & 42,9 & 42,2 & 0,7 & 0,5 & 0,2 \\
\hline 9 & $\mathrm{C} 2$ & 23,3 & 22,5 & 0,8 & 0,6 & 0,3 \\
\hline 10 & C8 & 43,4 & 42,5 & 1,0 & 0,8 & 0,6 \\
\hline
\end{tabular}

${ }^{*}$ ) $\mathrm{Xi}$ e $\mathrm{Yi}$ : valores médios de consumo $\mathrm{em} \mathrm{m}^{3} / \mathrm{mês} /$ ligação $\sum$ : 3,3

$\left.{ }^{\star \star}\right)$ F1 a F15: áreas com VRP Fixa

Caracteristicas de Di: AMPLITUDE: 2,0 MÉDIA (MD): 0,2 MEDIANA: $\quad 0,3$

$\mathrm{H} 0: \mathrm{MD}=0$ (o consumo médio, antes e após a data de entrada em operação da VRP, não variou) $\mathrm{H} 1: \mathrm{MD} \neq 0$ (o consumo médio, antes e após a data de entrada em operação da VRP, variou)

$$
\begin{aligned}
& \text { Média: } \mathrm{MD}=0,2 \\
& \text { Variância: } \mathrm{SD}^{2}=\sum(\mathrm{Di}-\mathrm{MD})^{2} /(\mathrm{n}-1)=\quad 3,3 / 9=\quad 0,4 \\
& \text { Desvio Padrão: } \mathrm{SD}=\sqrt{ } 1,1=\quad 0,61 \\
& \mathrm{t}_{\mathrm{obs}}=\mathrm{MD} /(\mathrm{SD} / \sqrt{(n)})=\quad 0,2 / 0,61 / \sqrt{ } 10=1,141 \\
& t_{\text {crtico: }}: t_{c}=2,262
\end{aligned}
$$

Como tobs $=1,141$ se encontra dentro do intervalo de confiança -tc $=-2,262$ e tc $=2,262$, não podemos rejeitar a hipótese $\mathrm{H} 0$ de que o consumo antes e após a data de entrada em operação da VRP, não variou, quando consideradas as áreas de VRP com controle automático de saída, com um grau de confiança de $95 \%$. 
ANÁLISE 5.2: ÁREAS DE VRP AUTOMÁTICA (até 3 econ./Lig.) TESTE DE HIPÓTESE DAS MÉDIAS DE CONSUMO ANTES E APÓS A REDUÇÃO DE PRESSÃO PROVOCADA PELA INSTALAÇÃO DA VRP

\begin{tabular}{|c|c|c|c|c|c|c|}
\hline & VRP & ANTES (Xi) & APÓS (Yi) & $\mathrm{Di}=(\mathrm{Xi}-\mathrm{Yi})$ & $\mathrm{Di}-\mathrm{MD}$ & $(\mathrm{Di}-\mathrm{MD})^{2}$ \\
\hline 1 & C5 & 16,2 & 17,2 & $-1,0$ & $-1,3$ & 1,6 \\
\hline 2 & C6 & 15,9 & 16,4 & $-0,5$ & $-0,7$ & 0,6 \\
\hline 3 & $\mathrm{C} 4$ & 22,1 & 22,3 & $-0,2$ & $-0,4$ & 0,2 \\
\hline 4 & C7 & 17,6 & 17,6 & 0,0 & $-0,3$ & 0,1 \\
\hline 5 & C9 & 22,2 & 22,1 & 0,2 & $-0,1$ & 0,0 \\
\hline 6 & C1 & 29,2 & 28,9 & 0,3 & 0,0 & 0,0 \\
\hline 7 & C3 & 22,9 & 22,3 & 0,6 & 0,3 & 0,1 \\
\hline 8 & $\mathrm{C} 2$ & 22,6 & 22,0 & 0,6 & 0,4 & 0,2 \\
\hline 9 & C8 & 29,6 & 28,4 & 1,2 & 0,9 & 0,9 \\
\hline 10 & C10 & 36,3 & 34,9 & 1,4 & 1,2 & 1,4 \\
\hline \multicolumn{7}{|c|}{ valores médios de consumo em m³/mês/ligação } \\
\hline
\end{tabular}

${ }^{*}$ ) $\mathrm{Xi}$ e Yi: valores médios de consumo em $\mathrm{m}^{3} / \mathrm{mês/ligação}$

$\left.{ }^{* \star}\right)$ F1 a F15: áreas com VRP Fixa

Caracteristicas de Di: AMPLITUDE: 2,4

MÉDIA (MD): 0,2

MEDIANA: $\quad 0,2$

H0: MD = 0 (o consumo médio, antes e após a data de entrada em operação da VRP, não variou) $\mathrm{H} 1: \mathrm{MD} \neq 0$ (o consumo médio, antes e após a data de entrada em operação da VRP, variou)

$$
\begin{aligned}
& \text { Média: } \mathrm{MD}=0,2 \\
& \text { Variância: } \mathrm{SD}^{2}=\sum(\mathrm{Di}-\mathrm{MD})^{2} /(\mathrm{n}-1)=\quad 4,9 / 9=\quad 0,5 \\
& \text { Desvio Padrão: } \mathrm{SD}=\sqrt{ } 1,1=\quad 0,74 \\
& \mathrm{t}_{\mathrm{obs}}=\mathrm{MD} /(\mathrm{SD} / \sqrt{(n)})=\quad 0,2 / 0,74 / \sqrt{ } 10=1,061 \\
& t_{\text {crtico: }}: t_{c}=2,262
\end{aligned}
$$

Como tobs $=1,061$ se encontra dentro do intervalo de confiança -tc $=-2,262$ e tc $=2,262$, não podemos rejeitar a hipótese $\mathrm{H} 0$ de que o consumo antes e após a data de entrada em operação da VRP, não variou, quando consideradas as áreas de VRP com controle automático de saída, com um grau de confiança de $95 \%$. 
ANÁLISE 5.3: ÁREAS DE VRP AUTOMÁTICA (1 econ./Lig.) TESTE DE HIPÓTESE DAS MÉDIAS DE CONSUMO ANTES E APÓS A REDUÇÃO DE PRESSÃO PROVOCADA PELA INSTALAÇÃO DA VRP

\begin{tabular}{|c|c|c|c|c|c|c|}
\hline & VRP & ANTES (Xi) & APÓS (Yi) & $\mathrm{Di}=(\mathrm{Xi}-\mathrm{Yi})$ & $\mathrm{Di}-\mathrm{MD}$ & $(\mathrm{Di}-\mathrm{MD})^{2}$ \\
\hline 1 & $\mathrm{C} 5$ & 14,1 & 15,0 & $-0,8$ & $-1,1$ & 1,2 \\
\hline 2 & C6 & 14,1 & 14,6 & $-0,5$ & $-0,7$ & 0,5 \\
\hline 3 & $\mathrm{C} 4$ & 21,7 & 22,1 & $-0,4$ & $-0,6$ & 0,4 \\
\hline 4 & $\mathrm{C} 7$ & 16,8 & 16,8 & 0,0 & $-0,3$ & 0,1 \\
\hline 5 & C9 & 21,8 & 21,6 & 0,2 & $-0,1$ & 0,0 \\
\hline 6 & $\mathrm{C} 1$ & 28,9 & 28,7 & 0,3 & 0,0 & 0,0 \\
\hline 7 & $\mathrm{C} 2$ & 22,0 & 21,4 & 0,6 & 0,3 & 0,1 \\
\hline 8 & C3 & 22,7 & 22,0 & 0,6 & 0,4 & 0,2 \\
\hline 9 & $\mathrm{C} 8$ & 29,6 & 28,4 & 1,2 & 0,9 & 0,9 \\
\hline 10 & C10 & 36,3 & 34,9 & 1,4 & 1,2 & 1,4 \\
\hline
\end{tabular}

${ }^{*}$ ) $\mathrm{Xi}$ e Yi: valores médios de consumo em $\mathrm{m}^{3} / \mathrm{mês/ligação}$

$\left.{ }^{* \star}\right)$ F1 a F15: áreas com VRP Fixa

Caracteristicas de Di: AMPLITUDE: 2,2

MÉDIA (MD): 0,2

MEDIANA: $\quad 0,2$

H0: MD = 0 (o consumo médio, antes e após a data de entrada em operação da VRP, não variou) $\mathrm{H} 1: \mathrm{MD} \neq 0$ (o consumo médio, antes e após a data de entrada em operação da VRP, variou)

$$
\begin{aligned}
& \text { Média: } \mathrm{MD}=0,2 \\
& \text { Variância: } \mathrm{SD}^{2}=\sum(\mathrm{Di}-\mathrm{MD})^{2} /(\mathrm{n}-1)=\quad 4,7 / 9=\quad 0,5 \\
& \text { Desvio Padrão: } \mathrm{SD}=\sqrt{1,1}=\quad 0,72 \\
& \mathrm{t}_{\mathrm{obs}}=\mathrm{MD} /(\mathrm{SD} / \sqrt{(\mathrm{n}))}=\quad 0,2 / 0,72 / \sqrt{ } 10=1,059 \\
& t_{\text {crtico: }}: t c=2,262
\end{aligned}
$$

Como tobs $=1,059$ se encontra dentro do intervalo de confiança -tc $=-2,262$ e tc $=2,262$, não podemos rejeitar a hipótese $\mathrm{H} 0$ de que o consumo antes e após a data de entrada em operação da VRP, não variou, quando consideradas as áreas de VRP com controle automático de saída, com um grau de confiança de $95 \%$. 


\section{ANÁLISE 6: ÁREAS TESTEMUNHA DE VRP COM SAÍDA FIXA TESTE DE HIPÓTESE DAS MÉDIAS DE CONSUMO ANTES E APÓS A REDUÇÃO DE PRESSÃO PROVOCADA PELA INSTALAÇÃO DA VRP}

\begin{tabular}{|c|c|c|c|c|c|c|}
\hline & ÁREA & ANTES $(\mathrm{Xi})$ & APÓS (Yi) & $D i=(X i-Y i)$ & $\mathrm{Di}-\mathrm{MD}$ & $(\mathrm{Di}-\mathrm{MD})^{2}$ \\
\hline 1 & F15 Test. & 13,0 & 14,1 & $-1,2$ & $-1,9$ & 3,7 \\
\hline 2 & F1 Test. & 15,9 & 15,8 & 0,1 & $-0,7$ & 0,5 \\
\hline 3 & F3 Test. & 17,2 & 17,0 & 0,2 & $-0,5$ & 0,3 \\
\hline 4 & F17 Test. & 14,3 & 14,0 & 0,2 & $-0,5$ & 0,3 \\
\hline 5 & F9 Test. & 22,2 & 21,7 & 0,5 & $-0,3$ & 0,1 \\
\hline 6 & F8 Test. & 22,6 & 22,0 & 0,6 & $-0,2$ & 0,0 \\
\hline 7 & F2 Test. & 18,5 & 17,8 & 0,7 & 0,0 & 0,0 \\
\hline 3 & F11 Test. & 14,5 & 13,7 & 0,8 & 0,0 & 0,0 \\
\hline 9 & F6 Test. & 15,4 & 14,3 & 1,1 & 0,3 & 0,1 \\
\hline & F7 Test. & 19,7 & 18,4 & 1,2 & 0,5 & 0,2 \\
\hline & F4 Test. & 19,7 & 18,4 & 1,3 & 0,5 & 0,2 \\
\hline 2 & F16 Test. & 16,3 & 14,9 & 1,5 & 0,7 & 0,5 \\
\hline 3 & F10 Test. & 43,6 & 42,1 & 1,5 & 0,7 & 0,5 \\
\hline 4 & F13 Test. & 54,2 & 52,6 & 1,6 & 0,8 & 0,6 \\
\hline & F12 Test. & 22,6 & 21,0 & 1,6 & 0,8 & 0,7 \\
\hline \multicolumn{7}{|c|}{ res médios de consumo $\theta$} \\
\hline
\end{tabular}

$\left.{ }^{*}\right) \mathrm{Xi}$ e $\mathrm{Yi}$ : valores médios de consumo $\mathrm{em} \mathrm{m}^{3} / \mathrm{mês} /$ ligação

$\left.{ }^{(*}\right) \mathrm{F} 1$ a F15: áreas com VRP Fixa

Caracteristicas de Di: AMPLITUDE: 2,8 MÉDIA (MD): 0,8 MEDIANA: $\quad 0,8$

H0: MD = 0 (o consumo médio, antes e após a data de entrada em operação da VRP, não variou) $\mathrm{H} 1: \mathrm{MD} \neq 0$ (o consumo médio, antes e após a data de entrada em operação da VRP, variou)

$$
\begin{aligned}
& \text { Média: } \mathrm{MD}=0,8 \\
& \text { Variância: } \mathrm{SD}^{2}=\sum(\mathrm{Di}-\mathrm{MD})^{2} /(\mathrm{n}-1)=\quad 7,7 / 14=\quad 0,6 \\
& \text { Desvio Padrão: } \mathrm{SD}=\sqrt{ } 0,6=0,74 \\
& \mathrm{t}_{\mathrm{obs}}=\mathrm{MD} /(\mathrm{SD} / \sqrt{ }(\mathrm{n}))=\quad 0,8 / 0,74 / \sqrt{15}=4,066
\end{aligned}
$$

Na tabela de Distribuição Student:

graus de liberdade: $\mathrm{gl}:(\mathrm{n}-1)=14$

nivel de significância: $\alpha=0,01$

$$
t_{\text {critico: }} \text { tc }=2,977
$$

Como tobs $=4,066$ se encontra fora do intervalo de confiança - tc $=-2,977$ e tc $=2,977$, podemos rejeitar a hipótese $\mathrm{H} 0$ de que o consumo antes e após a data de entrada em operação da VRP não variou, quando consideradas as áreas testemunha de VRP com saida fixa, com um grau de confiança de $99 \%$.

Nesse caso, podemos afirmar que foi observada uma tendência de redução de consumo médio nas ligações pertencentes a essas áreas testemunha. 
ANÁLISE 6.1: ÁREAS TEST. VRP FIXA (até 12 econ./Lig.) TESTE DE HIPÓTESE DAS MÉDIAS DE CONSUMO ANTES E APÓS A REDUÇÃO DE PRESSÃO PROVOCADA PELA INSTALAÇÃO DA VRP

\begin{tabular}{|c|c|c|c|c|c|c|}
\hline & ÁREA & ANTES (Xi) & APÓS (Yi) & $\mathrm{Di}=(\mathrm{Xi}-\mathrm{Yi})$ & Di - MD & $(\mathrm{Di}-\mathrm{MD})^{2}$ \\
\hline 1 & F15 Test. & 13,0 & 14,1 & $-1,2$ & $-2,0$ & 3,9 \\
\hline 2 & F1 Test. & 15,9 & 15,8 & 0,1 & $-0,7$ & 0,5 \\
\hline 3 & F3 Test. & 17,2 & 17,0 & 0,2 & $-0,6$ & 0,4 \\
\hline 4 & F17 Test. & 14,3 & 14,0 & 0,2 & $-0,6$ & 0,3 \\
\hline 5 & F9 Test. & 22,2 & 21,7 & 0,5 & $-0,4$ & 0,1 \\
\hline 6 & F8 Test. & 22,2 & 21,6 & 0,5 & $-0,3$ & 0,1 \\
\hline 7 & F2 Test. & 18,5 & 17,8 & 0,7 & $-0,1$ & 0,0 \\
\hline 8 & F11 Test. & 14,5 & 13,7 & 0,8 & $-0,1$ & 0,0 \\
\hline 9 & F10 Test. & 33.1 & 32,2 & 0.9 & 0.1 & 0,0 \\
\hline 0 & F6 Test. & 15,4 & 14.3 & 1.1 & 0.3 & 0.1 \\
\hline 1 & F7 Test. & 197 & 18.4 & 1.2 & 0.4 & 0.2 \\
\hline 2 & F4 Test. & 19,7 & 18,4 & 1,3 & 0,4 & 0,2 \\
\hline 3 & F16 Test. & 16,3 & 14,9 & 1,5 & 0,6 & 0,4 \\
\hline 4 & F13 Test. & 54,2 & 52,6 & 1,6 & 0,7 & 0,5 \\
\hline 5 & F12 Test. & 22,5 & 21,0 & 1,6 & 0,8 & 0,6 \\
\hline 6 & F5 Test. & 22,8 & 20,5 & 2,2 & 1,4 & 2,0 \\
\hline
\end{tabular}

${ }^{(*)} \mathrm{Xi}$ e Yi: valores médios de consumo em $\mathrm{m}^{3 /} / \mathrm{mês} /$ ligação $\sum$ :

9,3

${ }^{(\star *)}$ F1 a F15: áreas com VRP Fixa

Características de Di: AMPLITUDE: 3,4 MÉDIA (MD): 0,8 MEDIANA: $\quad 0,8$

H0: $\mathrm{MD}=0$ (o consumo médio, antes e após a data de entrada em operação da VRP, não variou) H1: MD $\neq 0$ (o consumo médio, antes e após a data de entrada em operação da VRP, variou)

$$
\begin{aligned}
& \text { Média: } \mathrm{MD}=0,8 \\
& \text { Variância: } \mathrm{SD}^{2}=\sum(\mathrm{Di}-\mathrm{MD})^{2} /(\mathrm{n}-1)=\quad 9,3 / 15=\quad 0,6 \\
& \text { Desvio Padrão: } \mathrm{SD}=\sqrt{ } 0,6=\quad 0,79 \\
& \mathrm{t}_{\mathrm{obs}}=\mathrm{MD} /(\mathrm{SD} / \sqrt{ }(\mathrm{n}))=\quad 0,8 / 0,79 / \sqrt{ } 16=4,211 \\
& t_{\text {critico: }} \text { : } t c=2,947
\end{aligned}
$$

Como tobs $=4,211$ se encontra fora do intervalo de confiança $-t c=-2,947$ e tc $=2,947$, podemos rejeitar a hipótese $\mathrm{H} 0$ de que o consumo antes e após a data de entrada em operação da VRP não variou, quando consideradas as áreas testemunha de VRP com saída fixa, com um grau de confiança de $99 \%$.

Nesse caso, podemos afirmar que foi observada uma tendência de redução de consumo médio nas ligações pertencentes a essas áreas testemunha. 
ANÁLISE 6.2: ÁREAS TEST. VRP FIXA (até 3 econ./Lig.) TESTE DE HIPÓTESE DAS MÉDIAS DE CONSUMO ANTES E APÓS A REDUÇÃO DE PRESSÃO PROVOCADA PELA INSTALAÇÃO DA VRP

\begin{tabular}{|c|c|c|c|c|c|c|}
\hline & ÁREA & ANTES (Xi) & APÓS (Yi) & $\mathrm{Di}=(\mathrm{Xi}-\mathrm{Yi})$ & $\mathrm{Di}-\mathrm{MD}$ & $(\mathrm{Di}-\mathrm{MD})^{2}$ \\
\hline & F14 Test. & 20,9 & 22,1 & $-1,2$ & $-1,8$ & 3,2 \\
\hline & F15 Test. & 13,0 & 14,1 & $-1,1$ & $-1,7$ & 2,9 \\
\hline 3 & F13 Test. & 21,0 & 21,5 & $-0,5$ & $-1,1$ & 1,1 \\
\hline 4 & F1 Test. & 15,5 & 15,4 & 0,1 & $-0,5$ & 0,2 \\
\hline 5 & F17 Test. & 14,2 & 14,0 & 0,2 & $-0,3$ & 0,1 \\
\hline & F3 Test. & 17,1 & 16,8 & 0,3 & $-0,3$ & 0,1 \\
\hline 7 & F9 Test. & 22,2 & 21,7 & 0,5 & $-0,1$ & 0,0 \\
\hline 8 & F8 Test. & 21,8 & 21,2 & 0,5 & $-0,1$ & 0,0 \\
\hline 9 & F2 Test. & 18,1 & 17,4 & 0,7 & 0,1 & 0,0 \\
\hline & F11 Test. & 14,5 & 13,7 & 0,8 & 0,2 & 0,0 \\
\hline & F10 Test. & 31,4 & 30,6 & 0,8 & 0,2 & 0,0 \\
\hline & F6 Test. & 15,4 & 14,3 & 1,1 & 0,5 & 0,3 \\
\hline & F7 Test. & 19,5 & 18,2 & 1,2 & 0,7 & 0,4 \\
\hline & F4 Test. & 18,9 & 17,6 & 1,4 & 0,8 & 0,6 \\
\hline & F16 Test. & 16,3 & 14,9 & 1,5 & 0,9 & 0,8 \\
\hline & F12 Test. & 20,2 & 18,7 & 1,5 & 0,9 & 0,8 \\
\hline & F5 Test. & 21,0 & 18,8 & 2,2 & 1,6 & 2,6 \\
\hline
\end{tabular}

${ }^{*}$ ) $\mathrm{Xi}$ e Yi: valores médios de consumo em $\mathrm{m}^{3 / m e ̂ s / l i g a c ̧ a ̃ o ~}$ $\Sigma$ : 13,3

$\left.{ }^{(*}\right)$ F1 a F15: áreas com VRP Fixa

Caracteristicas de Di: AMPLITUDE: 3,4

MÉDIA (MD): 0,6

MEDIANA: $\quad 0,7$

$\mathrm{H} 0: \mathrm{MD}=0$ (o consumo médio, antes e após a data de entrada em operação da VRP, não variou) $\mathrm{H} 1: \mathrm{MD} \neq 0$ (o consumo médio, antes e após a data de entrada em operação da VRP, variou)

Média: $M D=0,6$

Variância: $\mathrm{SD}^{2}=\sum(\mathrm{Di}-\mathrm{MD})^{2} /(\mathrm{n}-1)=\quad 13,3 / 16=\quad 0,8$

Desvio Padrão: $\mathrm{SD}=\sqrt{0,6}=\quad 0,91$

$$
\mathrm{t}_{\mathrm{obs}}=\mathrm{MD} /(\mathrm{SD} / \sqrt{ }(\mathrm{n}))=\quad 0,6 / 0,91 / \sqrt{ } 17=2,631
$$

Na tabela de Distribuição Student:

graus de liberdade: $g l:(n-1)=16$

nivel de significância: $\alpha=0,01$

$$
t_{\text {critico: }}: \text { tc }=2,921
$$

Como tobs $=2,631$ se encontra dentro do intervalo de confiança - tc $=-2,921$ e tc $=2,921$, não podemos rejeitar a hipótese $\mathrm{H} 0$ de que o consumo antes e após a data de entrada em operação da VRP não variou, quando consideradas as áreas testemunha de VRP com saida fixa, com um grau de confiança de $99 \%$.

Na tabela de Distribuição Student:

$$
\begin{aligned}
\text { graus de liberdade: } & \text { gl: }(n-1)=16 \\
\text { nivel de significância: } & \alpha=0,05 \\
t_{\text {crtico: }}: & \text { tc }=2,120
\end{aligned}
$$

Como tobs $=2,631$ se encontra fora do intervalo de confiança - tc $=-2,120$ e tc $=2,120$, podemos rejeitar a hipótese $\mathrm{HO}$ de que o consumo antes e após a data de entrada em operação da VRP não variou, quando consideradas as áreas testemunha de VRP com saída fixa, com um grau de confiança de $95 \%$

Nesse último caso, podemos afirmar que foi observada uma tendência de redução de consumo médio nas ligações pertencentes a essas áreas testemunha. 
ANÁLISE 6.3: ÁREAS TEST. VRP FIXA (1 econ./Lig.)

TESTE DE HIPÓTESE DAS MÉDIAS DE CONSUMO ANTES E APÓS A REDUÇÃO DE PRESSÃO PROVOCADA PELA INSTALAÇÃO DA VRP

\begin{tabular}{|c|c|c|c|c|c|c|}
\hline & ÁREA & ANTES (Xi) & APÓS (Yi) & $D i=(X i-Y i)$ & $\mathrm{Di}-\mathrm{MD}$ & $(\mathrm{Di}-\mathrm{MD})^{2}$ \\
\hline & F15 Test. & 12,8 & 13,8 & $-1,0$ & $-1,7$ & 2,8 \\
\hline & F14 Test. & 21,9 & 22,5 & $-0,6$ & $-1,3$ & 1,7 \\
\hline & F1 Test. & 14,1 & 14,1 & 0,1 & $-0,6$ & 0,4 \\
\hline & F13 Test. & 21,2 & 21,1 & 0,1 & $-0,6$ & 0,3 \\
\hline & F17 Test. & 13,6 & 13,4 & 0,2 & $-0,5$ & 0,2 \\
\hline & F3 Test. & 16,0 & 15,7 & 0,2 & $-0,4$ & 0,2 \\
\hline & F8 Test. & 21,4 & 21,0 & 0,4 & $-0,3$ & 0,1 \\
\hline & F9 Test. & 22,2 & 21,7 & 0,5 & $-0,2$ & 0,0 \\
\hline & F2 Test. & 16,7 & 16,1 & 0,6 & 0,0 & 0,0 \\
\hline & F10 Test. & 31,5 & 30,7 & 0,8 & 0,1 & 0,0 \\
\hline & F11 Test. & 14,0 & 13,0 & 1,0 & 0,3 & 0,1 \\
\hline & F6 Test. & 14,4 & 13,3 & 1,1 & 0,4 & 0,2 \\
\hline & F12 Test. & 18,3 & 17,1 & 1,2 & 0,5 & 0,3 \\
\hline & F7 Test. & 19,0 & 17,7 & 1,2 & 0,6 & 0,3 \\
\hline & F4 Test. & 17,8 & 16,2 & 1,6 & 1,0 & 0,9 \\
\hline & F16 Test. & 15,9 & 14,2 & 1,7 & 1,1 & 1,2 \\
\hline & F5 Test. & 21,1 & 18,9 & 2,2 & 1,5 & 2,3 \\
\hline & & & & & $\Sigma$ & 11,0 \\
\hline
\end{tabular}

$\left.{ }^{\star *}\right)$ F1 a F15: áreas com VRP Fixa

Caracteristicas de Di: AMPLITUDE: 3,2

MÉDIA (MD): 0,7

MEDIANA: $\quad 0,6$

$\mathrm{H} 0: \mathrm{MD}=0$ (o consumo médio, antes e após a data de entrada em operação da VRP, não variou) H1: MD $\neq 0$ (o consumo médio, antes e após a data de entrada em operação da VRP, variou)

$$
\text { Média: } \mathrm{MD}=\quad 0,7
$$

Variância: $\mathrm{SD}^{2}=\sum(\mathrm{Di}-\mathrm{MD})^{2} /(\mathrm{n}-1)=\quad 11,0 / 16=\quad 0,7$

Desvio Padrão: $\mathrm{SD}=\sqrt{ } 0,7=0,83$

$$
\mathrm{t}_{\mathrm{obs}}=\mathrm{MD} /(\mathrm{SD} / \sqrt{ }(\mathrm{n}))=\quad 0,7 / 0,83 / \sqrt{ } 17=3,262
$$

Na tabela de Distribuição Student:

graus de liberdade: $g l:(n-1)=16$

nivel de significância: $\alpha=0,01$

$$
t_{\text {crtico: }}: \text { tc }=2,921
$$

Como tobs $=3,262$ se encontra fora do intervalo de confiança $-\mathrm{tc}=-2,921$ e tc $=2,921$, podemos rejeitar a hipótese $\mathrm{H} 0$ de que o consumo antes e após a data de entrada em operação da VRP não variou, quando consideradas as áreas testemunha de VRP com saída fixa, com um grau de confiança de $99 \%$.

Nesse caso, podemos afirmar que foi observada uma tendência de redução de consumo médio nas ligações pertencentes a essas áreas testemunha. 


\section{ANÁLISE 7: ÁREAS TESTEMUNHA DE VRP CONTROLE AUTOMÁTICO TESTE DE HIPÓTESE DAS MÉDIAS DE CONSUMO ANTES E APÓS A REDUÇÃO DE PRESSÃO PROVOCADA PELA INSTALAÇÃO DA VRP}

\begin{tabular}{|c|c|c|c|c|c|c|}
\hline & ÁREA & ANTES $(\mathrm{Xi})$ & APÓS $(\mathrm{Yi})$ & $\mathrm{Di}=(\mathrm{Xi}-\mathrm{Yi})$ & $\mathrm{Di}-\mathrm{MD}$ & $(\mathrm{Di}-\mathrm{MD})^{2}$ \\
\cline { 2 - 7 } 1 & C6 Test. & 16,6 & 17,6 & $-1,0$ & $-1,0$ & 1,0 \\
\cline { 2 - 7 } 2 & C5 Test. & 16,8 & 17,6 & $-0,8$ & $-0,8$ & 0,7 \\
\hline & C1 Test. & 36,1 & 36,8 & $-0,7$ & $-0,7$ & 0,5 \\
\cline { 2 - 7 } 4 & C2 Test. & 88,0 & 88,1 & $-0,2$ & $-0,1$ & 0,0 \\
\hline & C7 Test. & 19,3 & 19,3 & $-0,1$ & $-0,1$ & 0,0 \\
\cline { 2 - 7 } 6 & C9 Test. & 38,9 & 38,6 & 0,3 & 0,3 & 0,1 \\
\hline & C4 Test. & 30,0 & 29,0 & 1,0 & 1,0 & 0,9 \\
\cline { 2 - 7 } 8 & C8 Test. & 83,5 & 82,0 & 1,5 & 1,5 & 2,3 \\
\hline
\end{tabular}

${ }^{(*)} \mathrm{Xi}$ e Yi: valores médios de consumo $\mathrm{em} \mathrm{m}^{3} / \mathrm{mês} /$ ligação

$\sum$ : 5,5

${ }^{\left({ }^{*}\right)}$ F1 a F15: áreas com VRP Fixa

Caracteristicas de Di: AMPLITUDE: 2,5 MÉDIA (MD): 0,0 MEDIANA: $\quad-0,1$

H0: $\mathrm{MD}=0$ (o consumo médio, antes e após a data de entrada em operação da VRP, não variou) H1: MD $\neq 0$ (o consumo médio, antes e após a data de entrada em operação da VRP, variou)

$$
\text { Média: } M D=0,0
$$

Variância: $\mathrm{SD}^{2}=\sum(\mathrm{Di}-\mathrm{MD})^{2} /(\mathrm{n}-1)=$ Desvio Padrão: $\mathrm{SD}=\sqrt{ } 0,8=0,89$

$$
5,5 / 7=\quad 0,8
$$

$$
\mathrm{t}_{\mathrm{obs}}=\mathrm{MD} /(\mathrm{SD} / \sqrt{ }(\mathrm{n}))=
$$$$
0,0 / 0,89 / \sqrt{ } 8=-0,044
$$

Na tabela de Distribuição Student:

$$
\text { graus de liberdade: } \mathrm{gl}:(\mathrm{n}-1)=7
$$

nivel de significância: $\alpha=0,05$

$$
t_{\text {critico: }}: t c=2,365
$$

Como tobs $=-0,044$ se encontra dentro do intervalo de confiança $-\mathrm{tc}=-2,365$ e tc $=2,365$, não podemos rejeitar a hipótese $\mathrm{H} 0$ de que o consumo antes e após a data de entrada em operação da VRP, não variou, quando consideradas as áreas de VRP com controle automático de saída, com um grau de confiança de $95 \%$. 
ANÁLISE 7.1: ÁREAS TESTEMUNHA DE VRP AUTOM. (até 12 econ./Lig.) TESTE DE HIPÓTESE DAS MÉDIAS DE CONSUMO ANTES E APÓS A REDUÇÃO DE PRESSÃO PROVOCADA PELA INSTALAÇÃO DA VRP

\begin{tabular}{|c|c|c|c|c|c|c|}
\hline & ÁREA & ANTES (Xi) & APÓS (Yi) & $D i=(X i-Y i)$ & $\mathrm{Di}-\mathrm{MD}$ & $(\mathrm{Di}-\mathrm{MD})^{2}$ \\
\hline 1 & C6 Test. & 16,6 & 17,6 & $-1,0$ & $-1,3$ & 1,6 \\
\hline 2 & C5 Test. & 15,3 & 16,0 & $-0,7$ & $-1,0$ & 0,9 \\
\hline 3 & C10 Test. & 31,7 & 32,1 & $-0,5$ & $-0,7$ & 0,5 \\
\hline 4 & C1 Test. & 29,4 & 29,8 & $-0,5$ & $-0,7$ & 0,5 \\
\hline 5 & C9 Test. & 25,7 & 26,1 & $-0,3$ & $-0,6$ & 0,3 \\
\hline 6 & C7 Test. & 17,6 & 17,9 & $-0,2$ & $-0,5$ & 0,2 \\
\hline 7 & C3 Test. & 37,7 & 37,5 & 0,2 & $-0,1$ & 0,0 \\
\hline 8 & C8 Test. & 32,5 & 31,0 & 1,5 & 1,3 & 1,6 \\
\hline 9 & C4 Test. & 25,5 & 23,8 & 1,7 & 1,4 & 2,1 \\
\hline 0 & C2 Test. & 45,7 & 43,4 & 2,3 & 2,1 & 4,4 \\
\hline
\end{tabular}

${ }^{*}$ ) $\mathrm{Xi}$ e $\mathrm{Yi}$ : valores médios de consumo $\mathrm{em} \mathrm{m}^{3} / \mathrm{mês} /$ ligação $\sum$ : 12,3

${ }^{(*)}$ F1 a F15: áreas com VRP Fixa

Caracteristicas de Di: AMPLITUDE: 3,4 MÉDIA (MD): 0,2 MEDIANA: $\quad-0,3$

$\mathrm{H} 0: \mathrm{MD}=0$ (o consumo médio, antes e após a data de entrada em operação da VRP, não variou) $\mathrm{H} 1: \mathrm{MD} \neq 0$ (o consumo médio, antes e após a data de entrada em operação da VRP, variou)

$$
\begin{aligned}
& \text { Média: } \mathrm{MD}=\quad 0,2 \\
& \text { Variância: } \mathrm{SD}^{2}=\sum(\mathrm{Di}-\mathrm{MD})^{2} /(\mathrm{n}-1)=\quad 12,3 / 9=\quad 1,4 \\
& \text { Desvio Padrão: } \mathrm{SD}=\sqrt{1,4}=1,17 \\
& \mathrm{t}_{\mathrm{obs}}=\mathrm{MD} /(\mathrm{SD} / \sqrt{(n)})=\quad 0,2 / 1,17 / \sqrt{10}=0,654
\end{aligned}
$$

Na tabela de Distribuição Student:

graus de liberdade: gl: $(n-1)=9$

nivel de significância: $\alpha=0,05$

$$
t_{\text {critico: }} \text { tc }=2,262
$$

Como tobs $=0,654$ se encontra dentro do intervalo de confiança -tc $=-2,262$ e tc $=2,262$, não podemos rejeitar a hipótese $\mathrm{H} 0$ de que o consumo antes e após a data de entrada em operação da VRP, não variou, quando consideradas as áreas de VRP com controle automático de saída, com um grau de confiança de $95 \%$. 
ANÁLISE 7.2: ÁREAS TESTEMUNHA DE VRP AUTOM. (até 3 econ./Lig.) TESTE DE HIPÓTESE DAS MÉDIAS DE CONSUMO ANTES E APÓS A REDUÇÃO DE PRESSÃO PROVOCADA PELA INSTALAÇÃO DA VRP

\begin{tabular}{|c|c|c|c|c|c|c|}
\hline & ÁREA & ANTES (Xi) & APÓS (Yi) & $D i=(X i-Y i)$ & Di - MD & $(\mathrm{Di}-\mathrm{MD})^{2}$ \\
\hline 1 & C6 Test. & 16,2 & 17,2 & $-1,0$ & $-1,2$ & 1,4 \\
\hline 2 & C5 Test. & 15,0 & 15,8 & $-0,7$ & $-0,9$ & 0,9 \\
\hline 3 & C10 Test. & 23,1 & 23,7 & $-0,6$ & $-0,8$ & 0,6 \\
\hline 4 & C1 Test. & 25,2 & 25,7 & $-0,5$ & $-0,8$ & 0,6 \\
\hline 5 & C3 Test. & 36,4 & 36,8 & $-0,4$ & $-0,6$ & 0,3 \\
\hline 6 & C7 Test. & 17,3 & 17,5 & $-0,2$ & $-0,5$ & 0,2 \\
\hline 7 & C9 Test. & 23,5 & 23,6 & $-0,1$ & $-0,3$ & 0,1 \\
\hline 8 & C8 Test. & 29,5 & 28,2 & 1,3 & 1,1 & 1,2 \\
\hline 9 & C4 Test. & 22,8 & 20,8 & 2,0 & 1,8 & 3,2 \\
\hline & C2 Test. & 45,7 & 43,4 & 2,3 & 2,1 & 4,5 \\
\hline
\end{tabular}

${ }^{*}$ ) $\mathrm{Xi}$ e Yi: valores médios de consumo $\mathrm{em} \mathrm{m}^{3} / \mathrm{mês} /$ ligação $\sum$ : 13,0

$\left.{ }^{\star \star *}\right)$ F1 a F15: áreas com VRP Fixa

Caracteristicas de Di: AMPLITUDE: $\quad 3,3$

MÉDIA (MD): $\quad 0,2$

MEDIANA: $\quad-0,3$

H0: $M D=0$ (o consumo médio, antes e após a data de entrada em operação da VRP, não variou) $\mathrm{H} 1: \mathrm{MD} \neq 0$ (o consumo médio, antes e após a data de entrada em operação da VRP, variou)

$$
\begin{aligned}
& \text { Média: } \mathrm{MD}=\quad 0,2 \\
& \text { Variância: } \mathrm{SD}^{2}=\sum(\mathrm{Di}-\mathrm{MD})^{2} /(\mathrm{n}-1)=\quad 13,0 / 9=\quad 1,4 \\
& \text { Desvio Padrão: } \mathrm{SD}=\sqrt{1,4}=1,20 \\
& \mathrm{t}_{\mathrm{obs}}=\mathrm{MD} /(\mathrm{SD} / \sqrt{(n)})=\quad 0,2 / 1,20 / \sqrt{ } 10=0,571
\end{aligned}
$$

Na tabela de Distribuição Student:

graus de liberdade: $\mathrm{gl}_{\mathrm{l}}(\mathrm{n}-1)=9$

nivel de significância: $\alpha=0,05$

$$
t_{\text {critico: }}: t c=2,262
$$

Como tobs $=0,571$ se encontra dentro do intervalo de confiança - tc $=-2,262$ e tc $=2,262$, não podemos rejeitar a hipótese $\mathrm{H} 0$ de que o consumo antes e após a data de entrada em operação da VRP, não variou, quando consideradas as áreas de VRP com controle automático de saída, com um grau de confiança de $95 \%$. 
ANÁLISE 7.3: ÁREAS TESTEMUNHA DE VRP AUTOM. (1 econ./Lig.) TESTE DE HIPÓTESE DAS MÉDIAS DE CONSUMO ANTES E APÓS A REDUÇÃO DE PRESSÃO PROVOCADA PELA INSTALAÇÃO DA VRP

\begin{tabular}{|c|c|c|c|c|c|c|}
\hline & ÁREA & ANTES $(\mathrm{Xi})$ & APÓS (Yi) & $D i=(X i-Y i)$ & Di - MD & $(\mathrm{Di}-\mathrm{MD})^{2}$ \\
\hline 1 & C6 Test. & 15,1 & 15,9 & $-0,8$ & $-1,1$ & 1,2 \\
\hline 2 & C5 Test. & 13,9 & 14,6 & $-0,7$ & $-0,9$ & 0,9 \\
\hline 3 & C1 Test. & 25,2 & 25,8 & $-0,7$ & $-0,9$ & 0,9 \\
\hline 4 & C3 Test. & 37,6 & 38,2 & $-0,6$ & $-0,8$ & 0,7 \\
\hline 5 & C10 Test. & 23,0 & 23,3 & $-0,3$ & $-0,6$ & 0,3 \\
\hline 6 & C7 Test. & 16,2 & 16,3 & $-0,2$ & $-0,4$ & 0,2 \\
\hline 7 & C9 Test. & 23,4 & 23,5 & $-0,1$ & $-0,4$ & 0,1 \\
\hline 8 & C8 Test. & 29,2 & 27,9 & 1,3 & 1,1 & 1,2 \\
\hline 9 & C4 Test. & 22,7 & 20,5 & 2,2 & 1,9 & 3,6 \\
\hline & C2 Test. & 46,3 & 43,9 & 2,4 & 2,1 & 4,6 \\
\hline
\end{tabular}

${ }^{*}$ ) $\mathrm{Xi}$ e Yi: valores médios de consumo $\mathrm{em}^{3} / \mathrm{mês/ligação}$ $\sum$ : 13,5

$\left.{ }^{\star \star}\right)$ F1 a F15: áreas com VRP Fixa

Caracteristicas de Di: AMPLITUDE: 3,2 MÉDIA (MD): 0,3 MEDIANA: $\quad-0,2$

$\mathrm{H} 0: \mathrm{MD}=0$ (o consumo médio, antes e após a data de entrada em operação da VRP, não variou) $\mathrm{H} 1: \mathrm{MD} \neq 0$ (o consumo médio, antes e após a data de entrada em operação da VRP, variou)

$$
\begin{aligned}
& \text { Média: } \mathrm{MD}=\quad 0,3 \\
& \text { Variância: } \mathrm{SD}^{2}=\sum(\mathrm{Di}-\mathrm{MD})^{2} /(\mathrm{n}-1)=\quad 13,5 / 9=\quad 1,5 \\
& \text { Desvio Padrão: } \mathrm{SD}=\sqrt{1,5}=1,23 \\
& \mathrm{t}_{\mathrm{obs}}=\mathrm{MD} /(\mathrm{SD} / \sqrt{(n)})=\quad 0,3 / 1,23 / \sqrt{ } 10=\quad 0,680 \\
& \text { graus de liberdade: } \text { gl: }(n-1)=9 \\
& \text { nivel de significância: } \alpha=0,05 \\
& t_{\text {crítico: }} \text { tc }=2,262
\end{aligned}
$$

Como tobs $=0,680$ se encontra dentro do intervalo de confiança - tc $=-2,262$ e tc $=2,262$, não podemos rejeitar a hipótese $\mathrm{H} 0$ de que o consumo antes e após a data de entrada em operação da VRP, não variou, quando consideradas as áreas de VRP com controle automático de saída, com um grau de confiança de $95 \%$. 


\section{APÊNDICE D: PLANILHAS COM OS TESTES DE HIPÓTESES, COMPARANDO AS ÁREAS DE VRP COM AS ÁREAS TESTEMUNHA, NAS ÁREAS ONDE AS DIFERENÇAS DE CONSUMO (ANTES - DEPOIS) DAS ÁREAS DE VRP APRESENTARAM A MESMA TENDÊNCIA QUE NAS ÁREAS TESTEMUNHA}

Os testes utilizados são os testes de hipóteses para comparação de duas séries de médias de amostras diferentes.

Obs.: todos os valores de média de consumo e de diferenças de média de consumo são dados em $\mathrm{m}^{3} / \mathrm{mês} /$ ligação. 
ANÁLISE 8: ÁREAS DE VRP x TESTEMUNHA SAÍDA FIXA

TESTE DE HIPÓTESE DAS DIFERENÇAS DAS MÉDIAS DE CONSUMO ANTES E APÓS A REDUÇÃO DE PRESSÃO PROVOCADA PELA INSTALAÇÃO DA VRP COM SAIDA DE PRESSÃO FIXA

\begin{tabular}{|c|c|c|}
\hline & \multicolumn{2}{|c|}{ Dif. (antes - depois) } \\
\hline & \multicolumn{2}{|c|}{ Área Testemunha } \\
\hline & F1 Test. & 0,1 \\
\hline 2 & F2 Test. & 0,7 \\
\hline 3 & F3 Test. & 0,2 \\
\hline 4 & F4 Test. & 1,3 \\
\hline 5 & F6 Test. & 1,1 \\
\hline 6 & F7 Test. & 1,2 \\
\hline$\gamma$ & F8 Test. & 0,6 \\
\hline 8 & F9 Test. & 0,5 \\
\hline 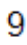 & F10 Test. & 1,5 \\
\hline 10 & F11 Test. & 0,8 \\
\hline 11 & F12 Test. & 1,6 \\
\hline 12 & F13 Test. & 1,6 \\
\hline TI & F15 Test. & $-1,2$ \\
\hline & F16 Test. & 1,5 \\
\hline & & \\
\hline
\end{tabular}

\begin{tabular}{|c|c|c|}
\hline & \multicolumn{2}{|c|}{ Dif. (antes - depois) } \\
\hline & Aáre & RP \\
\hline 1L & F1 & $-0,1$ \\
\hline 2 & $\mathrm{~F} 2$ & 1,3 \\
\hline 3 & $\mathrm{~F} 3$ & 0,2 \\
\hline 4 & $\mathrm{~F} 4$ & 1,7 \\
\hline 5 & F5 & 1,8 \\
\hline 6 & F6 & 0,8 \\
\hline 7 & $\mathrm{~F} 7$ & 1,4 \\
\hline 8 & F8 & $-0,2$ \\
\hline 9 & F9 & 2,5 \\
\hline 0 & F10 & 0,5 \\
\hline 1 & F11 & 1,2 \\
\hline 2 & F12 & $-0,1$ \\
\hline 3 & F13 & $-0,5$ \\
\hline 4 & F14 & $-0,5$ \\
\hline 5 & F15 & $-2,3$ \\
\hline 6 & F16 & 1,6 \\
\hline 17 & F17 & 0,5 \\
\hline
\end{tabular}

${ }^{*}$ ) valores médios de diferença de consumo $\mathrm{em}^{3} / \mathrm{mês} /$ ligação

${ }^{\left({ }^{*}\right)}$ F1 a F17: áreas com VRP Fixa

Dados amostrais:

\begin{tabular}{|r|c|c|}
\cline { 2 - 3 } \multicolumn{1}{c|}{} & A. Test & A. VRP \\
\hline Média (xi): & 0,8 & 0,6 \\
\hline Desvio Padrão: & 0,74 & 1,15 \\
\hline Tamanho da amostra: & 15 & 17 \\
\hline
\end{tabular}

$\mathrm{H} 0: \mathrm{MD}=0$ (a variação no consumo médio, antes e depois, foi a mesma) $\mathrm{H} 1: \mathrm{MD} \neq 0$ (a variação no consumo médio, antes e depois, não foi a mesma)

$$
\begin{gathered}
\mathrm{t}_{\text {calc }}=\left(\mathrm{x}_{1}-\mathrm{x}_{2}\right) / \sqrt{ }\left(\mathrm{s}_{1}{ }^{2} / \mathrm{n}_{1}+\mathrm{s}_{2}{ }^{2} / \mathrm{n}_{2}\right) \\
\mathrm{t}_{\text {calc }}=0,589
\end{gathered}
$$

Na tabela de Distribuição Student:

graus de liberdade: $\quad g l=\left(n_{1}+n_{2}-2\right)$

$$
\mathrm{gl}=30
$$

nivel de significância: $\alpha=0,05$

$$
t_{\text {crtico: }}: t c=2,042
$$

Como $t_{\text {calculado }}=0,646$ se encontra dentro do intervalo de confiança -tc $=-2,042$ e tc $=2,042$, não podemos rejeitar a hipótese $\mathrm{H} 0$ de que a variação no consumo, antes e após a data de entrada em operação da VRP, foi a mesma, com um grau de confiança de $95 \%$. 
ANÁLISE 8.1: ÁREAS DE VRP x TESTEMUNHA SAÍDA FIXA (até 12 econ./Lig.)

TESTE DE HIPÓTESE DAS DIFERENÇAS DAS MÉDIAS DE CONSUMO ANTES E APÓS A REDUÇÃO DE PRESSÃO PROVOCADA PELA INSTALAÇÃO DA VRP COM SAIDA DE PRESSÃO FIXA

\begin{tabular}{|c|c|c|}
\hline & \multicolumn{2}{|c|}{ Dif. (antes - depois) } \\
\hline & \multicolumn{2}{|c|}{ Área Testemunha } \\
\hline 1 & $\mathrm{~F} 1$ & 0,1 \\
\hline 2 & F2 & 0,7 \\
\hline 3 & F3 & 0,2 \\
\hline 4 & F4 & 1,3 \\
\hline 5 & F5 & 2,2 \\
\hline 6 & F6 & 1,1 \\
\hline 7 & F7 & 1,2 \\
\hline 8 & F8 & 0,5 \\
\hline 9 & F9 & 0,5 \\
\hline 0 & F10 & 0,9 \\
\hline 1 & F11 & 0,8 \\
\hline 2 & F12 & 1,6 \\
\hline 3 & F13 & 1,6 \\
\hline 4 & F15 & $-1,2$ \\
\hline 15 & F16 & 1,5 \\
\hline 16 & F17 & 0,2 \\
\hline
\end{tabular}

\begin{tabular}{|c|c|c|}
\hline & \multicolumn{2}{|c|}{ Dif. (antes - depois) } \\
\hline & \multicolumn{2}{|c|}{ Aárea de VRP } \\
\hline 1 & F1 & $-0,1$ \\
\hline 2 & F2 & 1,3 \\
\hline 3 & F3 & 0,2 \\
\hline 4 & F4 & 1,7 \\
\hline 5 & F5 & 1,4 \\
\hline 6 & F6 & 0,8 \\
\hline 7 & F7 & 1,4 \\
\hline 8 & F8 & $-0,2$ \\
\hline 9 & F9 & 2,5 \\
\hline 10 & F10 & 1,5 \\
\hline 11 & F11 & 1,2 \\
\hline 12 & F12 & $-0,1$ \\
\hline 13 & F13 & $-0,5$ \\
\hline 14 & F14 & $-0,5$ \\
\hline 15 & F15 & $-1,8$ \\
\hline 16 & F16 & 1,6 \\
\hline 17 & F17 & 0,5 \\
\hline
\end{tabular}

${ }^{*}$ ) valores médios de diferença de consumo em $\mathrm{m}^{3} / \mathrm{mês} /$ ligação

$\left.{ }^{\star \star *}\right)$ F1 a F17: áreas com VRP Fixa

Dados amostrais:

\begin{tabular}{|r|c|c|}
\cline { 2 - 3 } \multicolumn{1}{c|}{} & A. Test & A. VRP \\
\hline Média (xi): & 0,8 & 0,6 \\
\hline Desvio Padrão: & 0,79 & 1,08 \\
\hline Tamanho da amostra: & 16 & 17 \\
\hline
\end{tabular}

H0: $M D=0$ (a variação no consumo médio, antes e depois, foi a mesma)

$\mathrm{H} 1: \mathrm{MD} \neq 0$ (a variação no consumo médio, antes e depois, não foi a mesma)

$$
\begin{gathered}
\mathrm{t}_{\text {calc }}=\left(\mathrm{x}_{1}-\mathrm{x}_{2}\right) / \sqrt{ }\left(\mathrm{s}_{1}{ }^{2} / \mathrm{n}_{1}+\mathrm{s}_{2}{ }^{2} / \mathrm{n}_{2}\right) \\
\mathrm{t}_{\text {calc }}=0,560
\end{gathered}
$$

Na tabela de Distribuição Student:

graus de liberdade: $\quad g l=\left(n_{1}+n_{2}-2\right)$

$$
\mathrm{gl}=31
$$

nivel de significância: $\alpha=0,05$

$$
t_{\text {crtico: }}: \text { tc }=2,042
$$

Como $t_{\text {calculado }}=0,560$ se encontra dentro do intervalo de confiança -tc $=-2,042 \mathrm{e}$ tc $=2,042$, não podemos rejeitar a hipótese $\mathrm{H} 0$ de que a variação no consumo, antes e após a data de entrada em operação da VRP, foi a mesma, com um grau de confiança de $95 \%$. 
ANÁLISE 8.2: ÁREAS DE VRP x TESTEMUNHA SAIDA FIXA (até 3 econ./Lig.)

TESTE DE HIPÓTESE DAS DIFERENÇAS DAS MÉDIAS DE CONSUMO ANTES E APÓS A REDUÇÃO DE PRESSÃO PROVOCADA PELA INSTALAÇÃO DA VRP COM SAIDA DE PRESSÃO FIXA

\begin{tabular}{|c|c|c|}
\hline & \multicolumn{2}{|c|}{ Dif. (antes - depois) } \\
\hline & \multicolumn{2}{|c|}{ Área Testemunha } \\
\hline 1 & F1 & $-1,2$ \\
\hline 2 & $\mathrm{~F} 2$ & $-1,1$ \\
\hline 3 & F3 & $-0,5$ \\
\hline 4 & F4 & 0,1 \\
\hline 5 & F5 & 0,2 \\
\hline 6 & F6 & 0,3 \\
\hline 7 & F7 & 0,5 \\
\hline 8 & F8 & 0,5 \\
\hline 9 & F9 & 0,7 \\
\hline 10 & F10 & 0,8 \\
\hline 11 & F11 & 0,8 \\
\hline 12 . & F12 & 1,1 \\
\hline 13 & F13 & 1,2 \\
\hline 14 & F14 & 1.4 \\
\hline 15 & F15 & 1,5 \\
\hline 16 & F16 & 1,5 \\
\hline 17[ & F17 & 2,2 \\
\hline
\end{tabular}

\begin{tabular}{|c|c|c|}
\hline & \multicolumn{2}{|c|}{ Dif. (antes - depois) } \\
\hline & \multicolumn{2}{|c|}{ Aárea de VRP } \\
\hline 1 & $\mathrm{~F} 1$ & $-1,8$ \\
\hline 2 & F2 & $-0,4$ \\
\hline 3 & F3 & $-0,4$ \\
\hline 4 & $\mathrm{~F} 4$ & $-0,3$ \\
\hline 5 & F5 & $-0,1$ \\
\hline 5 & F6 & $-0,1$ \\
\hline 7 & F7 & 0,2 \\
\hline 3 & F8 & 0,5 \\
\hline 9 & F9 & 0,8 \\
\hline 0 & F10 & 1,2 \\
\hline 1 & F11 & 1,3 \\
\hline 2 & $\mathrm{~F} 12$ & 1,4 \\
\hline & F13 & 1,4 \\
\hline & F14 & 1,4 \\
\hline 5 & F15 & 1,6 \\
\hline 6 & F16 & 1,7 \\
\hline 17 & $\mathrm{~F} 17$ & 2,5 \\
\hline
\end{tabular}

${ }^{*}$ ) valores médios de diferença de consumo $\mathrm{em} \mathrm{m}^{3} / \mathrm{mês} /$ ligação

$\left.{ }^{(* *}\right)$ F1 a F17: áreas com VRP Fixa

Dados amostrais:

\begin{tabular}{|r|c|c|}
\cline { 2 - 3 } \multicolumn{1}{c|}{} & A. Test & A. VRP \\
\hline Média (xi): & 0,6 & 0,6 \\
\hline Desvio Padrão: & 0,91 & 1,07 \\
\hline Tamanho da amostra: & 17 & 17 \\
\hline
\end{tabular}

$\mathrm{H} 0: \mathrm{MD}=0$ (a variação no consumo médio, antes e depois, foi a mesma)

H1: MD $\neq 0$ (a variação no consumo médio, antes e depois, não foi a mesma)

$$
\begin{gathered}
\mathrm{t}_{\text {calc }}=\left(\mathrm{x}_{1}-\mathrm{x}_{2}\right) / \sqrt{ }\left(\mathrm{s}_{1}{ }^{2} / \mathrm{n}_{1}+\mathrm{s}_{2}{ }^{2} / \mathrm{n}_{2}\right) \\
\mathrm{t}_{\text {calc }}=-0,185
\end{gathered}
$$

Na tabela de Distribuição Student:

graus de liberdade: $\quad g l=\left(n_{1}+n_{2}-2\right)$

$$
\mathrm{gl}=32
$$

nivel de significância: $\alpha=0,05$

$$
t_{\text {crtico }}: \text { tc }=2,042
$$

Como $t_{\text {calculado }}=-0,185$ se encontra dentro do intervalo de confiança $-\mathrm{tc}=-2,042 \mathrm{e}$ tc $=2,042$, não podemos rejeitar a hipótese $\mathrm{H} 0$ de que a variação no consumo, antes e após a data de entrada em operação da VRP, foi a mesma, com um grau de confiança de $95 \%$. 
ANÁLISE 8.3: ÁREAS DE VRP x TESTEMUNHA SAÍDA FIXA (1 econ./Lig.)

TESTE DE HIPÓTESE DAS DIFERENÇAS DAS MÉDIAS DE CONSUMO ANTES E APÓS A REDUÇÃO DE PRESSÃO PROVOCADA PELA INSTALAÇÃO DA VRP COM SAIDA DE PRESSÃO FIXA

\begin{tabular}{|c|c|c|}
\hline & \multicolumn{2}{|c|}{ Dif. (antes - depois) } \\
\hline & \multicolumn{2}{|c|}{ Área Testemunha } \\
\hline 1 & F1 & $-1,0$ \\
\hline 2 & F2 & $-0,6$ \\
\hline 3 & F3 & 0,1 \\
\hline 4 & F4 & 0,1 \\
\hline 5 & F5 & 0,2 \\
\hline 6 & F6 & 0,2 \\
\hline 7 & F7 & 0,4 \\
\hline 8 & F8 & 0,5 \\
\hline 9 & F9 & 0,6 \\
\hline 10 & F10 & 0,8 \\
\hline 11 & F11 & 1,0 \\
\hline 12 . & F12 & 1,1 \\
\hline 13 & F13 & 1,2 \\
\hline 14 & F14 & 1.2 \\
\hline 15 & F15 & 1,6 \\
\hline 16 & F16 & 1,7 \\
\hline 17[ & F17 & 2,2 \\
\hline
\end{tabular}

\begin{tabular}{|c|c|c|}
\hline & \multicolumn{2}{|c|}{ Dif. (antes - depois) } \\
\hline & \multicolumn{2}{|c|}{ Aárea de VRP } \\
\hline 1 & $\mathrm{~F} 1$ & $-1,7$ \\
\hline 2 & $\mathrm{~F} 2$ & $-0,3$ \\
\hline 3 & F3 & $-0,3$ \\
\hline 4 & $\mathrm{~F} 4$ & $-0,3$ \\
\hline 5 & F5 & $-0,2$ \\
\hline 5 & F6 & $-0,2$ \\
\hline 7 & F7 & 0,2 \\
\hline 3 & F8 & 0,6 \\
\hline 9 & F9 & 0,7 \\
\hline 0 & F10 & 1,0 \\
\hline 1 & F11 & 1,1 \\
\hline 2 & F12 & 1,3 \\
\hline & F13 & 1,3 \\
\hline 4 & F14 & 1,4 \\
\hline 5 & F15 & 1,4 \\
\hline 6 & F16 & 1,6 \\
\hline 17 & F17 & 2,7 \\
\hline
\end{tabular}

${ }^{*}$ ) valores médios de diferença de consumo $\mathrm{em} \mathrm{m}^{3} / \mathrm{mês} /$ ligação

$\left.{ }^{(* *}\right)$ F1 a F17: áreas com VRP Fixa

Dados amostrais:

\begin{tabular}{|r|c|c|}
\cline { 2 - 3 } \multicolumn{1}{c|}{} & A. Test & A. VRP \\
\hline Média (xi): & 0,7 & 0,6 \\
\hline Desvio Padrão: & 0,83 & 1,03 \\
\hline Tamanho da amostra: & 17 & 17 \\
\hline
\end{tabular}

$\mathrm{H} 0: \mathrm{MD}=0$ (a variação no consumo médio, antes e depois, foi a mesma)

H1: MD $\neq 0$ (a variação no consumo médio, antes e depois, não foi a mesma)

$$
\begin{gathered}
\mathrm{t}_{\text {calc }}=\left(\mathrm{x}_{1}-\mathrm{x}_{2}\right) / \sqrt{ }\left(\mathrm{s}_{1}{ }^{2} / \mathrm{n}_{1}+\mathrm{s}_{2}{ }^{2} / \mathrm{n}_{2}\right) \\
\mathrm{t}_{\text {calc }}=0,153
\end{gathered}
$$

Na tabela de Distribuição Student:

graus de liberdade: $\quad \mathrm{gl}=\left(\mathrm{n}_{1}+\mathrm{n}_{2}-2\right)$

$$
\mathrm{gl}=32
$$

nivel de significância: $\alpha=0,05$

$$
t_{\text {crtico: }}: \text { tc }=2,042
$$

Como $\mathrm{t}_{\text {calculado }}=0,153$ se encontra dentro do intervalo de confiança $-\mathrm{tc}=-2,042 \mathrm{e}$ tc $=2,042$, não podemos rejeitar a hipótese $\mathrm{H} 0$ de que a variação no consumo, antes e após a data de entrada em operação da VRP, foi a mesma, com um grau de confiança de $95 \%$. 
ANÁLISE 9: ÁREAS TESTEMUNHA x VRP AUTOMÁTICA

TESTE DE HIPÓTESE DAS DIFERENÇAS DAS MÉDIAS DE CONSUMO ANTES E APÓS A REDUÇÃO DE PRESSÃO PROVOCADA PELA INSTALAÇÃO DA VRP COM SAIDA AUTOMÁTICA DE PRESSÃO

\begin{tabular}{|c|c|c|}
\hline & \multicolumn{2}{|c|}{ Dif. (antes - depois) } \\
\hline & \multicolumn{2}{|c|}{ Área Testemunha } \\
\hline 1 & $\mathrm{C} 1$ & $-0,7$ \\
\hline 2 & $\mathrm{C} 2$ & $-0,2$ \\
\hline 3 & $\mathrm{C} 4$ & 1,0 \\
\hline 4 & $\mathrm{C} 5$ & $-0,8$ \\
\hline 5 & C6 & $-1,0$ \\
\hline 5 & C7 & $-0,1$ \\
\hline 7 & C8 & 1,5 \\
\hline 3 & $\mathrm{C9}$ & 0,3 \\
\hline
\end{tabular}

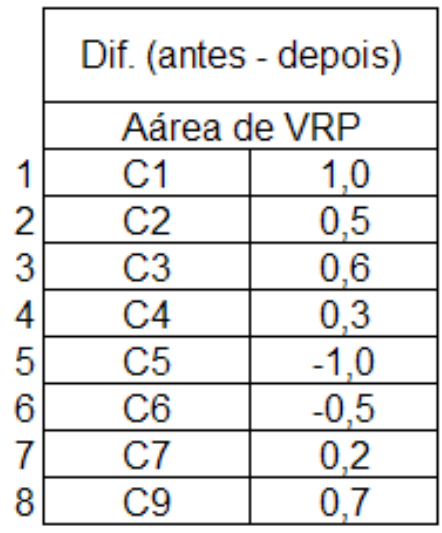

$\left.{ }^{*}\right)$ valores médios de diferença de consumo $\mathrm{em} \mathrm{m}^{3} / \mathrm{mês} /$ ligação

$\left.{ }^{* \star}\right)$ C1 a C10: áreas com VRP Automática

Dados amostrais:

\begin{tabular}{|r|c|c|}
\cline { 2 - 3 } \multicolumn{1}{c|}{} & A. Test & A. VRP \\
\hline Média (xi): & 0,0 & 0,2 \\
\hline Desvio Padrão: & 0,89 & 0,67 \\
\hline Tamanho da amostra: & 8 & 8 \\
\hline
\end{tabular}

$\mathrm{H} 0: \mathrm{MD}=0$ (a variação no consumo médio, antes e depois, foi a mesma) $\mathrm{H} 1: \mathrm{MD} \neq 0$ (a variação no consumo médio, antes e depois, não foi a mesma)

$$
\begin{gathered}
\mathrm{t}_{\text {calc }}=\left(\mathrm{x}_{1}-\mathrm{x}_{2}\right) / \sqrt{ }\left(\mathrm{s}_{1}{ }^{2} / \mathrm{n}_{1}+\mathrm{s}_{2}{ }^{2} / \mathrm{n}_{2}\right) \\
\mathrm{t}_{\text {calc }}=-0,607
\end{gathered}
$$

Na tabela de Distribuição Student:

graus de liberdade: $\quad g l=\left(n_{1}+n_{2}-2\right)$

$$
\mathrm{gl}=14
$$

nivel de significância: $\alpha=0,05$

$$
t_{\text {crítico: }} \text { tc }=2,145
$$

Como $t_{\text {calculado }}=-0,607$ se encontra dentro do intervalo de confiança -tc $=-2,145 \mathrm{e}$ tc $=2,145$, não podemos rejeitar a hipótese $\mathrm{H} 0$ de que a variação no consumo, antes e após a data de entrada em operação da VRP, foi a mesma, com um grau de confiança de $95 \%$. 
ANÁLISE 9.1: ÁREAS TESTEMUNHA x VRP AUTOMÁTICA (até 12 econ./Lig.)

TESTE DE HIPÓTESE DAS DIFERENÇAS DAS MÉDIAS DE CONSUMO ANTES E APÓS A REDUÇÃO DE PRESSÃO PROVOCADA PELA INSTALAÇÃO DA VRP COM SAIIDA AUTOMÁTICA DE PRESSÃO

\begin{tabular}{|c|c|c|}
\hline & \multicolumn{2}{|c|}{ Dif. (antes - depois) } \\
\hline & \multicolumn{2}{|c|}{ Área Testemunha } \\
\hline 1 & C1 & $-0,5$ \\
\hline 2 & $\mathrm{C} 2$ & 2,3 \\
\hline 3 & C3 & 0,2 \\
\hline 4 & C4 & 1,7 \\
\hline 5 & $\mathrm{C} 5$ & $-0,7$ \\
\hline 6 & C6 & $-1,0$ \\
\hline 7 & C7 & $-0,2$ \\
\hline 8 & $\mathrm{C} 8$ & 15 \\
\hline 9 & C9 & $-0,3$ \\
\hline 10 & C10 & $-0,5$ \\
\hline
\end{tabular}

\begin{tabular}{|c|c|c|}
\hline & \multicolumn{2}{|c|}{ Dif. (antes - depois) } \\
\hline & \multicolumn{2}{|c|}{ Aárea de VRP } \\
\hline 1 & $\mathrm{C} 1$ & 0,3 \\
\hline 2 & $\mathrm{C} 2$ & 0,8 \\
\hline 3 & $\mathrm{C} 3$ & 0,4 \\
\hline 4 & $\mathrm{C} 4$ & 0,3 \\
\hline 5 & C5 & $-1,0$ \\
\hline 6 & C6 & $-0,5$ \\
\hline 7 & $\mathrm{C7}$ & $-0,1$ \\
\hline 8 & C8 & 1,0 \\
\hline 9 & C9 & 0,4 \\
\hline 10 & C10 & 0,7 \\
\hline
\end{tabular}

$\left.{ }^{*}\right)$ valores médios de diferença de consumo $\mathrm{em} \mathrm{m}^{3} / \mathrm{mês} /$ ligação

$\left.{ }^{* *}\right) \mathrm{C} 1$ a C10: áreas com VRP Automática

Dados amostrais:

\begin{tabular}{|r|c|c|}
\cline { 2 - 3 } \multicolumn{1}{c|}{} & A. Test & A. VRP \\
\hline Média (xi): & 0,2 & 0,2 \\
\hline Desvio Padrão: & 1,17 & 0,61 \\
\hline Tamanho da amostra: & 10 & 10 \\
\hline
\end{tabular}

H0: $M D=0$ (a variação no consumo médio, antes e depois, foi a mesma) $\mathrm{H} 1: \mathrm{MD} \neq 0$ (a variação no consumo médio, antes e depois, não foi a mesma)

$$
\begin{gathered}
\mathrm{t}_{\text {calc }}=\left(\mathrm{x}_{1}-\mathrm{x}_{2}\right) / \sqrt{ }\left(\mathrm{s}_{1}{ }^{2} / \mathrm{n}_{1}+\mathrm{s}_{2}{ }^{2} / \mathrm{n}_{2}\right) \\
\mathrm{t}_{\text {calc }}=0,053
\end{gathered}
$$

Na tabela de Distribuição Student:

graus de liberdade: $\quad g l=\left(n_{1}+n_{2}-2\right)$

$$
\mathrm{gl}=18
$$

nivel de significância: $\alpha=0,05$

$$
t_{\text {crtico: }}: \text { tc }=2,101
$$

Como $t_{\text {calculado }}=0,053$ se encontra dentro do intervalo de confiança -tc $=-2,101 \mathrm{e}$ tc $=2,101$, não podemos rejeitar a hipótese $\mathrm{H} 0$ de que a variação no consumo, antes e após a data de entrada em operação da VRP, foi a mesma, com um grau de confiança de $95 \%$. 
ANÁLISE 9.2: ÁREAS TESTEMUNHA x VRP AUTOMÁTICA (até 3 econ./Lig.)

TESTE DE HIPÓTESE DAS DIFERENÇAS DAS MÉDIAS DE CONSUMO ANTES E APÓS A REDUÇÃO DE PRESSÃO PROVOCADA PELA INSTALAÇÃO DA VRP COM SAIIDA AUTOMÁTICA DE PRESSÃO

\begin{tabular}{|c|c|c|}
\hline & \multicolumn{2}{|c|}{ Dif. (antes - depois) } \\
\hline & \multicolumn{2}{|c|}{ Área Testemunha } \\
\hline 1 & C1 & $-0,5$ \\
\hline 2 & $\mathrm{C} 2$ & 2,3 \\
\hline 3 & C3 & $-0,4$ \\
\hline 4 & $\mathrm{C} 4$ & 2,0 \\
\hline 5 & $\mathrm{C} 5$ & $-0,7$ \\
\hline 6 & C6 & $-1,0$ \\
\hline 7 & $\mathrm{C7}$ & $-0,2$ \\
\hline 8 & $\mathrm{C} 8$ & 1,3 \\
\hline 9 & $\mathrm{C9}$ & $-0,1$ \\
\hline 10 & C10 & $-0,6$ \\
\hline
\end{tabular}

\begin{tabular}{|c|c|c|}
\hline & \multicolumn{2}{|c|}{ Dif. (antes - depois) } \\
\hline & \multicolumn{2}{|c|}{ Aárea de VRP } \\
\hline 1 & C1 & 0,3 \\
\hline 2 & $\mathrm{C} 2$ & 0,6 \\
\hline 3 & $\mathrm{C} 3$ & 0,6 \\
\hline 4 & $\mathrm{C} 4$ & $-0,2$ \\
\hline 5 & $\mathrm{C} 5$ & $-1,0$ \\
\hline 6 & C6 & $-0,5$ \\
\hline 7 & $\mathrm{C7}$ & 0,0 \\
\hline 8 & C8 & 1,2 \\
\hline 9 & C9 & 0,2 \\
\hline 10 & C10 & 14 \\
\hline
\end{tabular}

${ }^{*}$ ) valores médios de diferença de consumo em $\mathrm{m}^{3} / \mathrm{mês} /$ ligação

${ }^{(* *}$ C1 a C10: áreas com VRP Automática

Dados amostrais:

\begin{tabular}{|r|c|c|}
\cline { 2 - 3 } \multicolumn{1}{c|}{} & A. Test & A. VRP \\
\hline Média (xi): & 0,2 & 0,2 \\
\hline Desvio Padrão: & 1,20 & 0,74 \\
\hline Tamanho da amostra: & 10 & 10 \\
\hline
\end{tabular}

H0: $M D=0$ (a variação no consumo médio, antes e depois, foi a mesma)

$H 1: M D \neq 0$ (a variação no consumo médio, antes e depois, não foi a mesma)

$$
\begin{gathered}
\mathrm{t}_{\text {calc }}=\left(\mathrm{x}_{1}-\mathrm{x}_{2}\right) / \sqrt{ }\left(\mathrm{s}_{1}{ }^{2} / \mathrm{n}_{1}+\mathrm{s}_{2}{ }^{2} / \mathrm{n}_{2}\right) \\
\mathrm{t}_{\text {calc }}=-0,069
\end{gathered}
$$

Na tabela de Distribuição Student:

graus de liberdade: $\quad g l=\left(n_{1}+n_{2}-2\right)$

$$
\mathrm{gl}=18
$$

nivel de significância: $\alpha=0,05$

$$
t_{\text {critico: }}: t_{c}=2,101
$$

Como $t_{\text {calculado }}=-0,069$ se encontra dentro do intervalo de confiança $-t c=-2,101$ e tc $=2,101$, não podemos rejeitar a hipótese $\mathrm{H} 0$ de que a variação no consumo, antes e após a data de entrada em operação da VRP, foi a mesma, com um grau de confiança de $95 \%$. 
ANÁLISE 9.3: ÁREAS TESTEMUNHA x VRP AUTOMÁTICA (1 econ./Lig.)

TESTE DE HIPÓTESE DAS DIFERENÇAS DAS MÉDIAS DE CONSUMO ANTES E APÓS A REDUÇÃO DE PRESSÃO PROVOCADA PELA INSTALAÇÃO DA VRP COM SAIIDA AUTOMÁTICA DE PRESSÃO

\begin{tabular}{|c|c|c|}
\hline & \multicolumn{2}{|c|}{ Dif. (antes - depois) } \\
\hline & \multicolumn{2}{|c|}{ Área Testemunha } \\
\hline$1 \longdiv { 1 }$ & C1 & $-0,7$ \\
\hline 2 & $\mathrm{C} 2$ & 2,4 \\
\hline 3 & C3 & $-0,6$ \\
\hline 4 & $\mathrm{C} 4$ & 2,2 \\
\hline 5 & $\mathrm{C} 5$ & $-0,7$ \\
\hline 6 & C6 & $-0,8$ \\
\hline 7 & $\mathrm{C} 7$ & $-0,2$ \\
\hline 8 & $\mathrm{C} 8$ & 1,3 \\
\hline 9 & C9 & $-0,1$ \\
\hline 10[ & C10 & $-0,3$ \\
\hline
\end{tabular}

\begin{tabular}{|c|c|c|}
\hline & \multicolumn{2}{|c|}{ Dif. (antes - depois) } \\
\hline & \multicolumn{2}{|c|}{ Aárea de VRP } \\
\hline 1 & C1 & 0,3 \\
\hline 2 & $\mathrm{C} 2$ & 0,6 \\
\hline 3 & C3 & 0,6 \\
\hline 4 & $\mathrm{C} 4$ & $-0,4$ \\
\hline 5 & C5 & $-0,8$ \\
\hline 6 & C6 & $-0,5$ \\
\hline 7 & $\mathrm{C} 7$ & 0,0 \\
\hline 8 & $\mathrm{C} 8$ & 1,2 \\
\hline 9 & C9 & 0,2 \\
\hline 10 & $\mathrm{C} 10$ & 1,4 \\
\hline
\end{tabular}

$\left.{ }^{*}\right)$ valores médios de diferença de consumo em $\mathrm{m}^{3} / \mathrm{mês} /$ ligação

$\left.{ }^{(* *}\right)$ C1 a C10: áreas com VRP Automática

Dados amostrais:

\begin{tabular}{|r|c|c|}
\cline { 2 - 3 } \multicolumn{1}{c|}{} & A. Test & A. VRP \\
\hline Média (xi): & 0,3 & 0,2 \\
\hline Desvio Padrão: & 1,23 & 0,72 \\
\hline Tamanho da amostra: & 10 & 10 \\
\hline
\end{tabular}

H0: $\mathrm{MD}=0$ (a variação no consumo médio, antes e depois, foi a mesma)

H1: $M D \neq 0$ (a variação no consumo médio, antes e depois, não foi a mesma)

$$
\begin{gathered}
\mathrm{t}_{\text {calc }}=\left(\mathrm{x}_{1}-\mathrm{x}_{2}\right) / \sqrt{ }\left(\mathrm{s}_{1}{ }^{2} / \mathrm{n}_{1}+\mathrm{s}_{2}{ }^{2} / \mathrm{n}_{2}\right) \\
\mathrm{t}_{\text {calc }}=0,049
\end{gathered}
$$

Na tabela de Distribuiç̧ão Student:

graus de liberdade: $\quad g l=\left(n_{1}+n_{2}-2\right)$

$$
\mathrm{gl}=18
$$

nivel de significância: $\alpha=0,05$

$$
t_{\text {critico: }}: t=2,101
$$

Como $\mathrm{t}_{\text {calculado }}=0,049$ se encontra dentro do intervalo de confiança $-\mathrm{tc}=-2,101 \mathrm{e}$ tc $=2,101$, não podemos rejeitar a hipótese $\mathrm{H} 0$ de que a variação no consumo, antes e após a data de entrada em operação da VRP, foi a mesma, com um grau de confiança de $95 \%$. 
ANÁLISE 10: ÁREAS DE VRP x TESTEMUNHA

TESTE DE HIPÓTESE DAS DIFERENÇAS DAS MÉDIAS DE CONSUMO ANTES E APÓS A REDUÇÃO DE PRESSÃO PROVOCADA PELA INSTALAÇÃO DE VRP

\begin{tabular}{|c|c|c|}
\hline & \multicolumn{2}{|c|}{ Dif. (antes - depois) } \\
\hline & \multicolumn{2}{|c|}{ Área Testemunha } \\
\hline 1 & $\mathrm{C} 1$ & $-0,7$ \\
\hline 2 & $\mathrm{C} 2$ & $-0,2$ \\
\hline 3 & $\mathrm{C} 4$ & 1,0 \\
\hline 4[ & $\mathrm{C} 5$ & $-0,8$ \\
\hline 5 & $\mathrm{C} 6$ & $-1,0$ \\
\hline 6 & $\mathrm{C} 7$ & $-0,1$ \\
\hline 7 & $\mathrm{C} 8$ & 1,5 \\
\hline 8 & C9 & 0,3 \\
\hline 9 & $\mathrm{~F} 1$ & 0,1 \\
\hline 10 & $\mathrm{~F} 2$ & 0,7 \\
\hline 11 & $\mathrm{F3}$ & 0,2 \\
\hline 12 & F4 & 1,3 \\
\hline 13 & F6 & 1,1 \\
\hline 14 & F7 & 1,2 \\
\hline 15 & F8 & 0,6 \\
\hline 16 & F9 & 0,5 \\
\hline 17 & F10 & 1,5 \\
\hline 18 & F11 & 0,8 \\
\hline 19 & F12 & 1,6 \\
\hline 20 & F13 & 1,6 \\
\hline 21 & F14 & $-1,8$ \\
\hline 22 & F15 & $-1,2$ \\
\hline 23 & F16 & 1,5 \\
\hline 24 & F17 & 0,2 \\
\hline
\end{tabular}

\begin{tabular}{|c|c|c|}
\hline & \multicolumn{2}{|c|}{ Dif. (antes - depois) } \\
\hline & \multicolumn{2}{|c|}{ Aárea de VRP } \\
\hline 1 & $\mathrm{C} 1$ & 1,0 \\
\hline 2 & $\mathrm{C} 2$ & 0,5 \\
\hline 3 & $\mathrm{C} 3$ & 0,6 \\
\hline 4 & $\mathrm{C} 4$ & 0,3 \\
\hline 5 & $\mathrm{C} 5$ & $-1,0$ \\
\hline 6 & C6 & $-0,5$ \\
\hline 7 & $\mathrm{C7}$ & 0,2 \\
\hline 8 & C9 & 0,7 \\
\hline 9 & $\mathrm{~F} 1$ & $-0,1$ \\
\hline 10 & F2 & 1,3 \\
\hline 11 & F3 & 0,2 \\
\hline 12 & $\mathrm{~F} 4$ & 1,7 \\
\hline 13 & F5 & 1,8 \\
\hline 14 & F6 & 0,8 \\
\hline 15 & F7 & 1,4 \\
\hline 16 & F8 & $-0,2$ \\
\hline 17 & F9 & 2,5 \\
\hline 18 & F10 & 0,5 \\
\hline 19 & F11 & 1,2 \\
\hline 20 & F12 & $-0,1$ \\
\hline 21 & F13 & $-0,5$ \\
\hline 22 & F14 & $-0,5$ \\
\hline 23 & F16 & 1,6 \\
\hline 24 & F17 & 0,5 \\
\hline
\end{tabular}

(*) valores médios de diferença de consumo em $\mathrm{m}^{3 /} / \mathrm{mês} /$ ligação

${ }^{(*)}$ F1 a F17: áreas com VRP Fixa

Dados amostrais:

\begin{tabular}{|r|c|c|}
\cline { 2 - 3 } \multicolumn{1}{c|}{} & A. Test & A. VRP \\
\hline Média (xi): & 0,4 & 0,6 \\
\hline Desvio Padrão: & 0,97 & 0,87 \\
\hline Tamanho da amostra: & 24 & 24 \\
\hline
\end{tabular}

H0: $M D=0$ (a variação no consumo médio, antes e depois, foi a mesma)

$\mathrm{H} 1: \mathrm{MD} \neq 0$ (a variação no consumo médio, antes e depois, não foi a mesma)

$$
\begin{gathered}
\mathrm{t}_{\text {calc }}=\left(\mathrm{x}_{1}-\mathrm{x}_{2}\right) / \sqrt{ }\left(\mathrm{s}_{1}{ }^{2} / \mathrm{n}_{1}+\mathrm{s}_{2}{ }^{2} / \mathrm{n}_{2}\right) \\
\mathrm{t}_{\text {calc }}=-0,646
\end{gathered}
$$

Na tabela de Distribuição Student:

graus de liberdade: $\quad \mathrm{gl}=\left(\mathrm{n}_{1}+\mathrm{n}_{2}-2\right)$

$\mathrm{gl}=46$

nivel de significância: $\alpha=0,05$

$t_{\text {critico: }}:$ c $=2,010$

Como $\mathrm{t}_{\text {calculado }}=0,646$ se encontra dentro do intervalo de confiança -tc $=-2,010 \mathrm{e}$ tc $=2,010$, não podemos rejeitar a hipótese $\mathrm{H} 0$ de que a variação no consumo, antes e após a data de entrada em operação da VRP, foi a mesma, com um grau de confiança de $95 \%$. 